\title{
"THE GREAT CATARACT" Effects of Late Holocene Debris Flows on Lava Falls Rapid, Grand Canyon National Park, Arizona
}

U.S. GEOLOGICAL SURVEY

Open-File Report 96-460

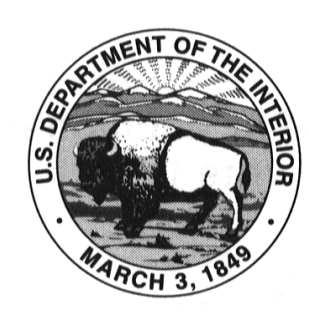


"THE GREAT CATARACT"

Effects of Late Holocene Debris Flows on Lava Falls Rapid, Grand Canyon National Park, Arizona

By ROBERT H. WEBB, THEODORE S. MELIS, THOMAS W. WISE, and JOHN G. ELLIOTT

U.S. GEOLOGICAL SURVEY

Open-File Report 96-460

Prepared in cooperation with the BUREAU OF RECLAMATION

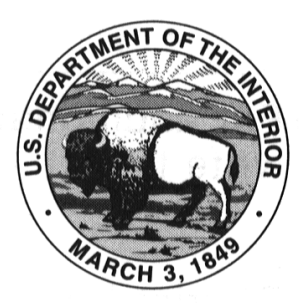




\title{
U.S. DEPARTMENT OF THE INTERIOR BRUCE BABBITT, Secretary
}

\author{
U.S. GEOLOGICAL SURVEY \\ Gordon P. Eaton, Director
}

For additional information write to:

Regional Research Hydrologist U.S. Geological Survey, MS-472 Water Resources Division 345 Middlefield Road Menlo Park, CA 94025
Copies of this report can be purchased from:

U.S. Geological Survey Branch of Information Services Box 25286

Denver, CO 80225 


\section{CONTENTS}

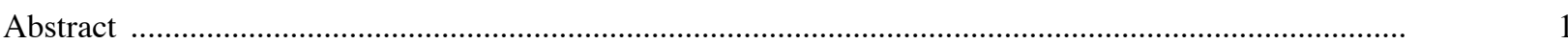

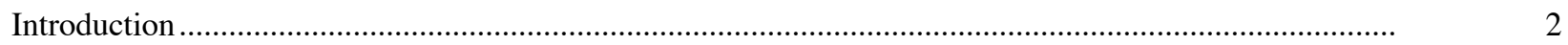

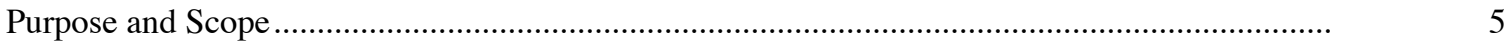

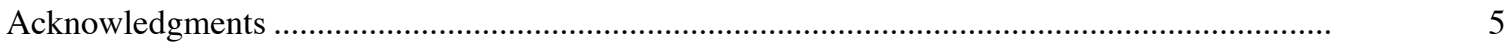

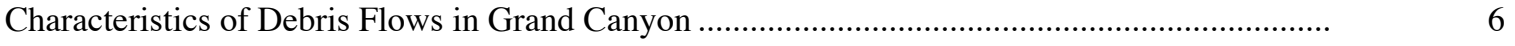

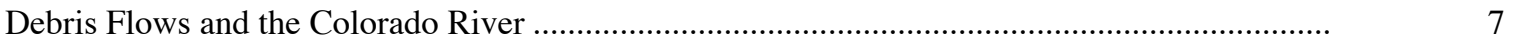

Methods

The Prospect Valley Drainage Basin .................................................................................... 8

Historical Photographs of Lava Falls Rapid .......................................................................... 10

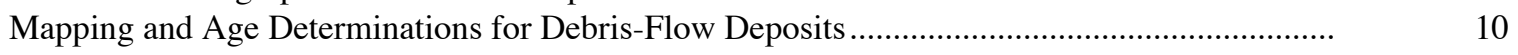

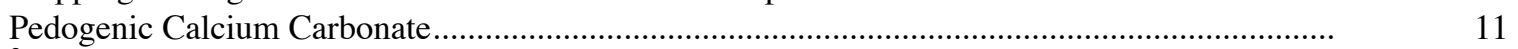

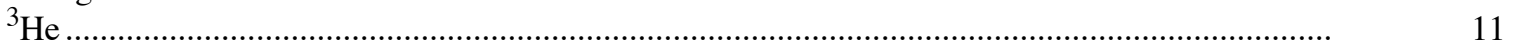

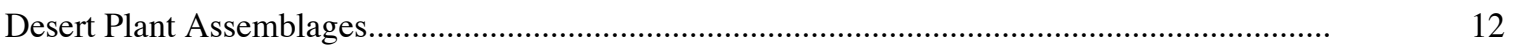

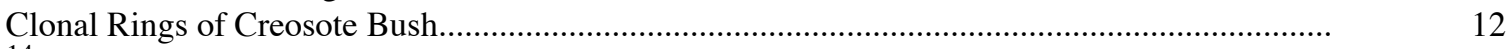

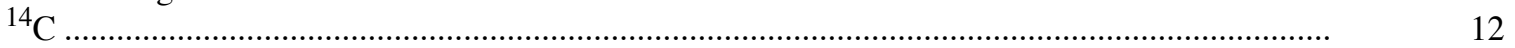

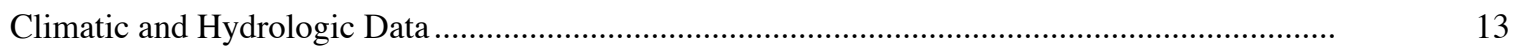

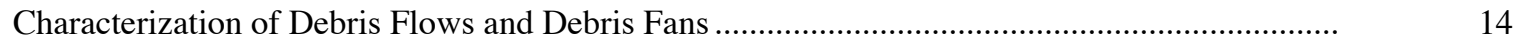

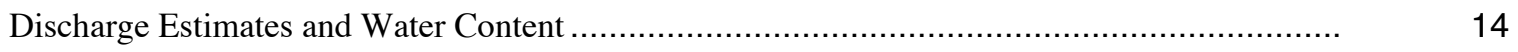

Surface Area and Volume..............................................................................................

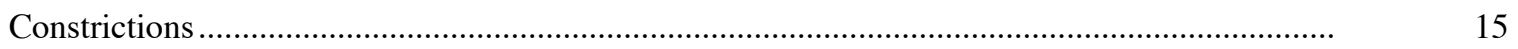

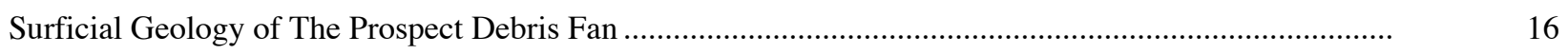

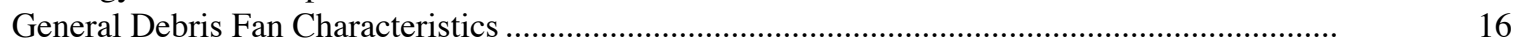

Fan-Forming Debris-Flow Surfaces ............................................................................ 18

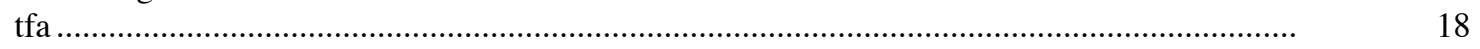

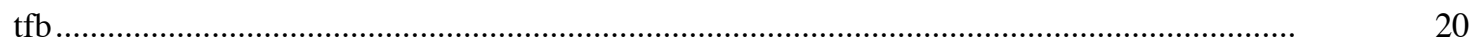

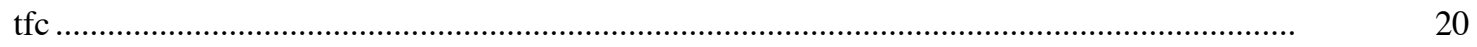

Inset Debris-Flow Surfaces.........................................................................................

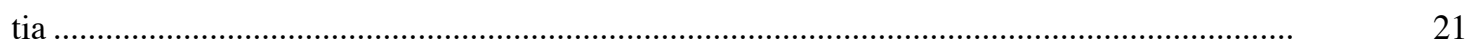

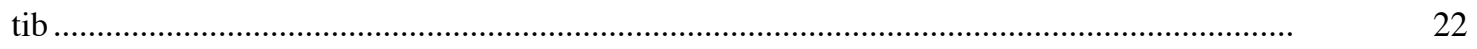

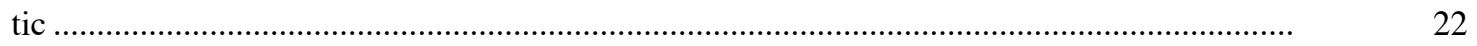

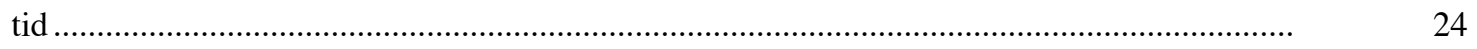

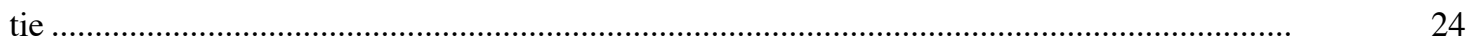

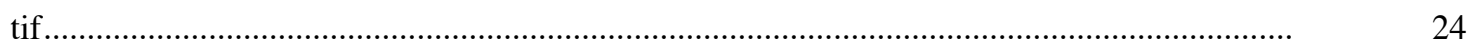

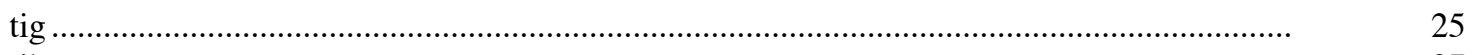

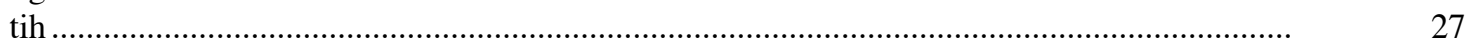

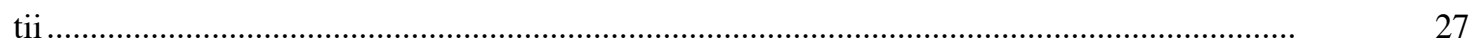

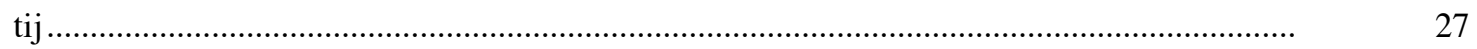

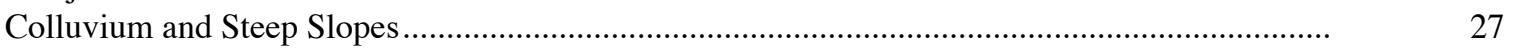

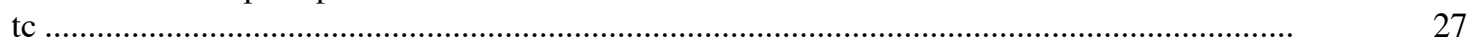

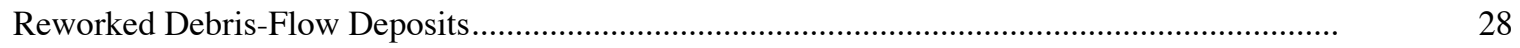

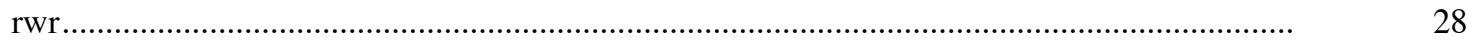

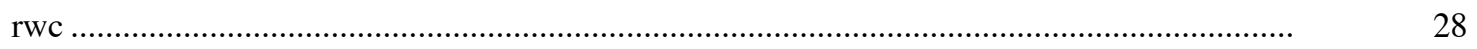

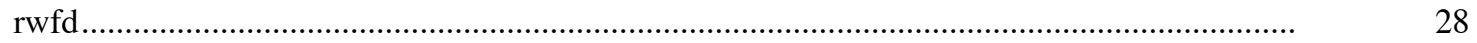

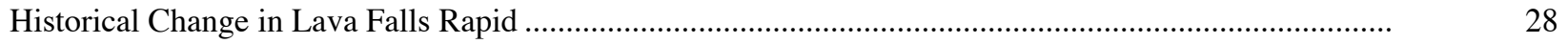

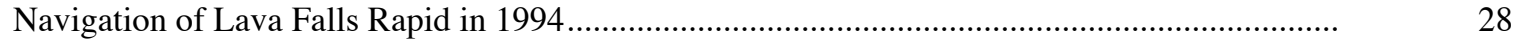

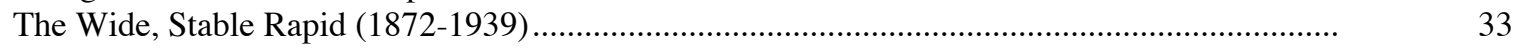

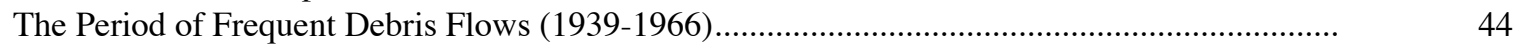

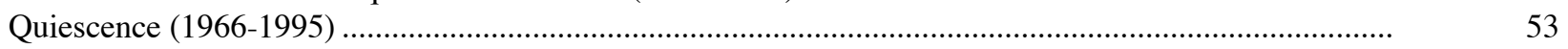

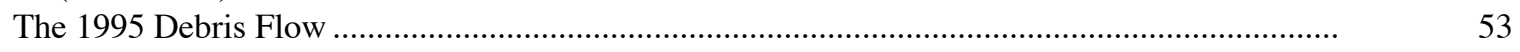

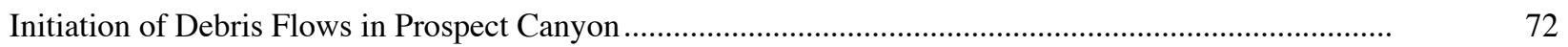




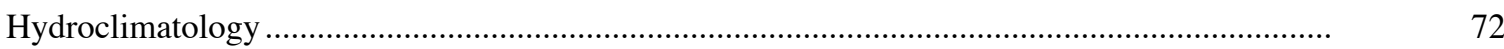

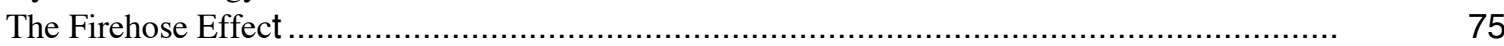

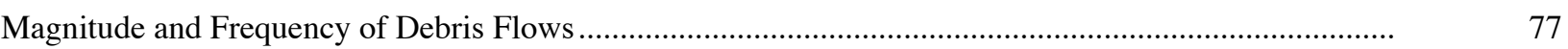

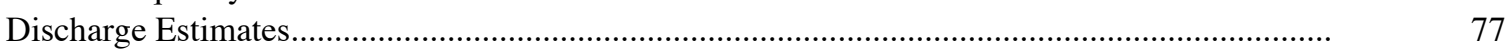

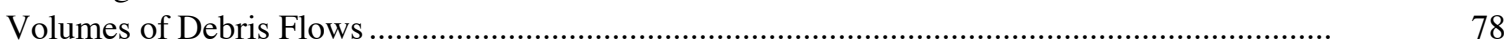

Constrictions of the Colorado River ............................................................................

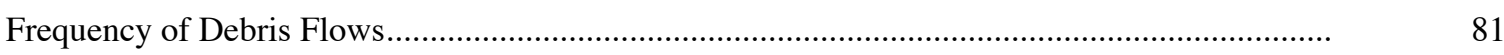

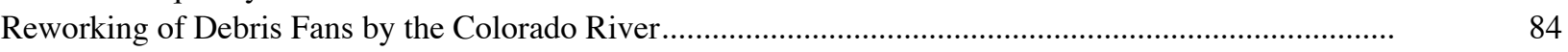

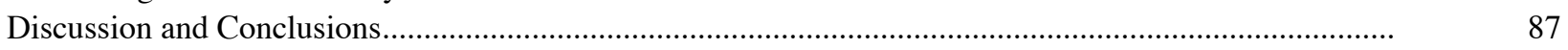

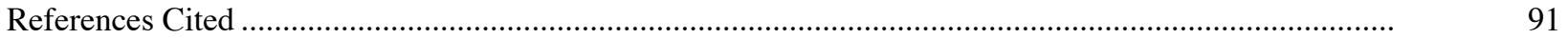

\section{FIGURES}

1. Maps of the study area

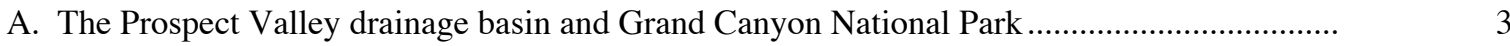

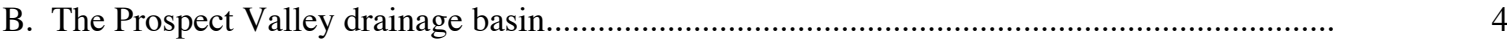

2. Map of Lava Falls and Lower Lava Rapids showing geomorphic features of the Colorado River. $\quad 7$

3. Geologic map of Prospect Canyon. This map is modified from Billingsley and Huntoon (1983) and Hamblin (1994b); the original scale is 1:62,500 .

4. Graphs showing particle-size distributions for debris flows in Prospect Canyon

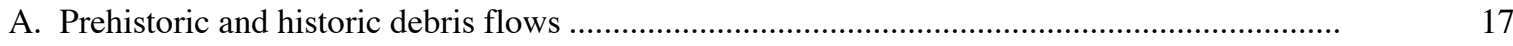

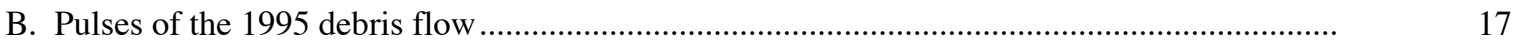

5. Graph showing source materials transported by debris flows in Prospect Canyon ......................... 19

6. Graph of cross section showing the relative elevations and positions of fan-forming and inset

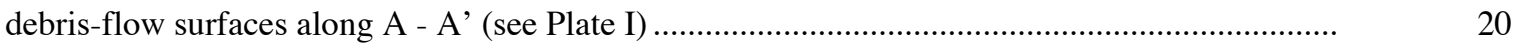

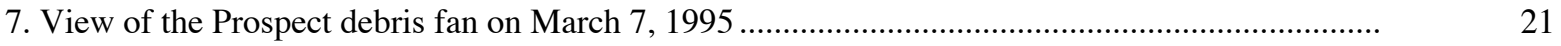

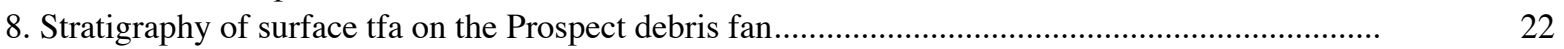

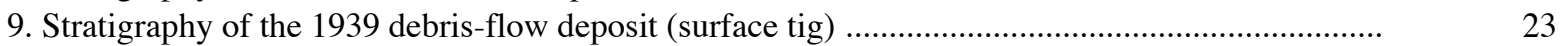

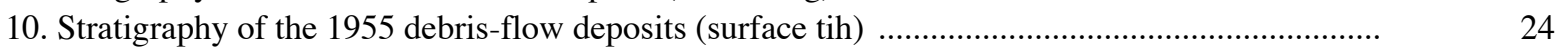

11. Maps of Lava Falls Rapid

A. Based on a 1994 aerial photograph, showing the modern configuration of Lava Falls Rapid. 25

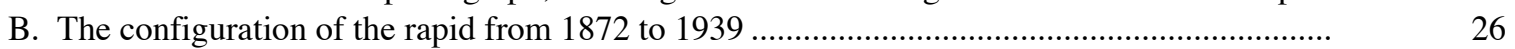

12. Replicate downstream views of Prospect Canyon and Lava Falls Rapid from Toroweap Overlook

13. Replicate downstream views of Lava Falls Rapid from the high surface on the left side

14. Upstream view of Lava Falls Rapid from the left side.

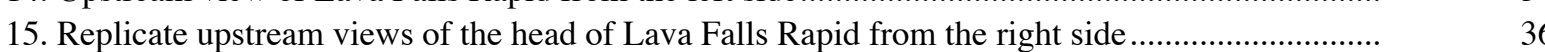

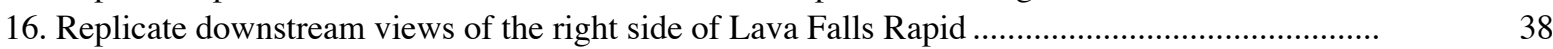

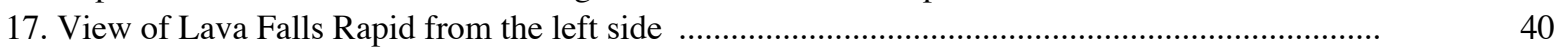

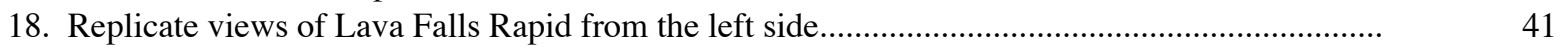

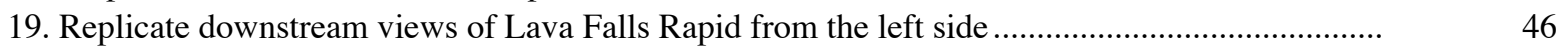

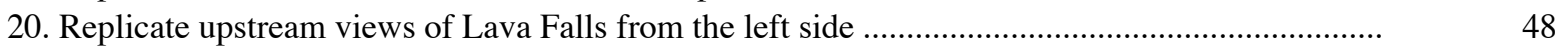

21. Oblique aerial views of Lava Falls Rapid and Prospect Canyon ................................................

22. Replicate downstream views of Prospect Canyon debris fan and lower Lava Falls Rapid .......... $\quad 54$

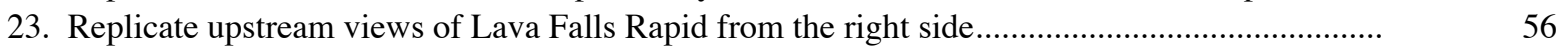

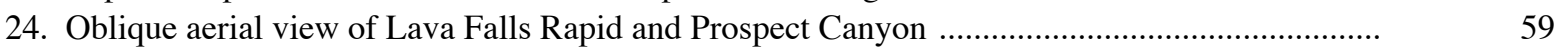

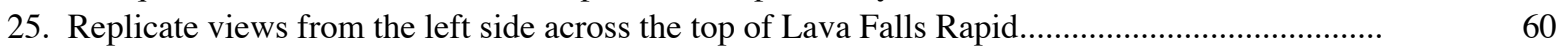


26. Replicate downstream views of Lava Falls Rapid from the high surface on the left side

27. View of the firehose effect created by streamflow falling over a $325-\mathrm{m}$ fall at the head of Prospect Canyon on March 6, 1995

28. Replicate vertical aerial photographs of Lava Falls Rapid.

29. Graphs showing longitudinal profile of the water-surface fall on the right side of Lava Falls Rapid

A. March 6-8, 1995

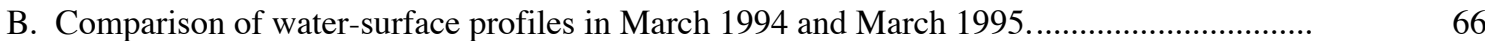

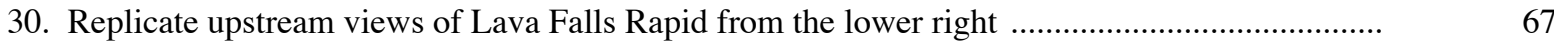

31. Replicate views across Lava Falls Rapid from river left

32. Graphs showing standardized seasonal precipitation for eight stations in the vicinity of western Grand Canyon (Appendix 2)

33. Graphs showing monthly precipitation near the Prospect Valley drainage basin associated with Prospect Canyon debris flows and floods

34. Graphs showing hourly precipitation at Tuweep Ranger Station and Grand Canyon during three historic debris flows and one flood in Prospect Canyon.....

35. Map showing the spatial extent of debris fans deposited by Holocene debris flows from Prospect Canyon

36. Graph showing the volume of sediments deposited on debris fans by historical debris flows in Grand Canyon (modified from Melis and others, 1994) and Holocene debris flows from Prospect Canyon

37. Graphs showing the constriction ratios of debris fans in Grand Canyon .....

38. Graph showing annual series of instantaneous peak discharges for the Colorado River near Grand Canyon, Arizona.....

39. Hydrographs of the Colorado River showing the timing of tributary floods and debris flows and river discharges

40. Hydrographs of the Colorado River from 1966 to 1974 showing the timing of the 1966 debris flow and releases from Glen Canyon Dam.

41. Graphs showing the effects of river reworking on particles on the Prospect debris fan

\section{TABLES}

1. Radiocarbon dates of organic material collected from debris-flow deposits at the mouth of Prospect Canyon.

2. Preliminary ranking of the area and volume of the 15 largest debris fans of probable Holocene age on the Colorado River in Grand Canyon National Park

3. Mineralogy of the clay-size fraction of Prospect Canyon debris flows compared with other Grand Canyon debris flows.....

4. Dates and photographic evidence for debris flows and other floods in Prospect Canyon .................

5. Peak discharge estimates from superelevation evidence for the debris flows of 1939, 1955, and 1963 in Prospect Canyon at cross section A - A'

6. Characteristics of debris fans deposited at the mouth of Prospect Canyon between 1939 and 1995 


\section{CONVERSION FACTORS}

For readers who prefer to use inch-pound units, conversion factors for the terms in this report are listed below:

\begin{tabular}{|c|c|c|}
\hline Multiply & By & To obtain \\
\hline millimeter $(\mathrm{mm})$ & 0.03937 & inch (in.) \\
\hline meter $(\mathrm{m})$ & 3.2818 & foot $(\mathrm{ft})$ \\
\hline square meter $\left(\mathrm{m}^{2}\right)$ & 10.76 & square foot $\left(\mathrm{ft}^{2}\right)$ \\
\hline cubic meter $\left(\mathrm{m}^{3}\right)$ & 35.31 & cubic foot $\left(\mathrm{ft}^{3}\right)$ \\
\hline kilometer $(\mathrm{km})$ & 0.6214 & mile (mi) \\
\hline square kilometer $\left(\mathrm{km}^{2}\right)$ & 0.3861 & square mile $\left(\mathrm{mi}^{2}\right)$ \\
\hline $\begin{array}{l}\text { cubic meter per second } \\
\qquad\left(\mathrm{m}^{3} / \mathrm{s}\right)\end{array}$ & 35.31 & $\begin{array}{l}\text { cubic foot per second } \\
\left(\mathrm{ft}^{3} / \mathrm{s}\right)\end{array}$ \\
\hline $\operatorname{gram}(\mathrm{g})$ & 0.03527 & $\begin{array}{l}\text { ounce avoirdupois } \\
\quad \text { (oz avdp) }\end{array}$ \\
\hline kilogram (kg) & 2.205 & $\begin{array}{l}\text { pound avoirdupois } \\
\text { (lb avdp) }\end{array}$ \\
\hline megagram (Mg) & 1.102 & $\begin{array}{l}\text { tons, short } \\
(2,000 \text { pounds })\end{array}$ \\
\hline
\end{tabular}

Sea level: In this report, "sea level” refers to the National Geodetic Vertical Datum of 1929 (NGVD of 1929)--a geodetic datum derived from a general adjustment of the first-order level nets of both the United States and Canada, formerly called "Sea Level Datum of 1929." 


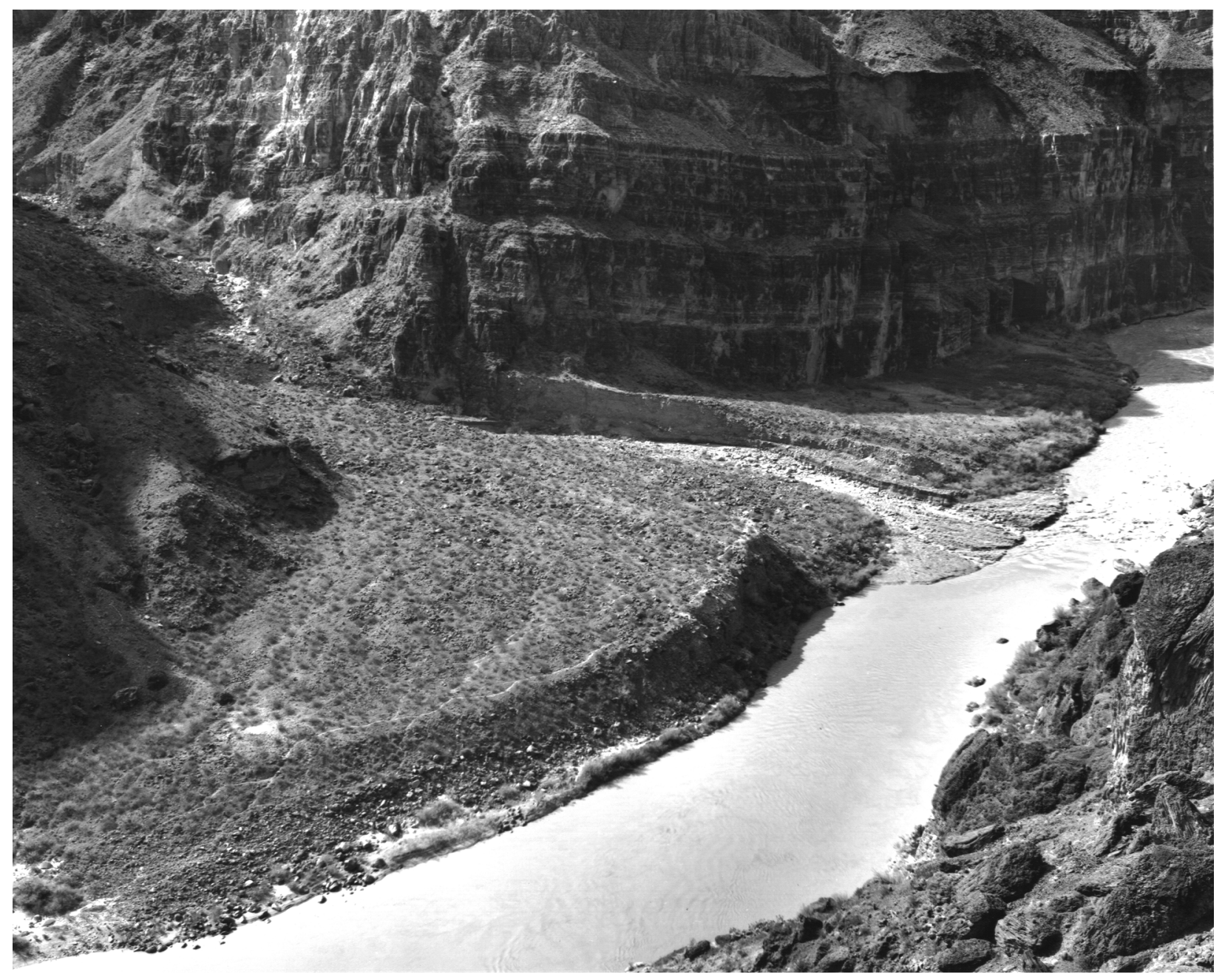

FRONTISPIECE. The Prospect Canyon debris fan and Lava Falls Rapid from the Tuweap Trail. 


\title{
"The Great Cataract" \\ Effects Of Late Holocene Debris Flows On Lava Falls Rapid, Grand Canyon National Park and Hualapai Indian Reservation, Arizona
}

\author{
By Robert H. Webb, Theodore S. Melis, Thomas W. Wise, and John G. Elliott
}

\section{ABSTRACT}

Lava Falls Rapid is the most formidable reach of whitewater on the Colorado River in Grand Canyon and is one of the most famous rapids in the world. Although the rapid was once thought to be controlled by the remnants of lava dams of Pleistocene age, Lava Falls was created and is maintained by frequent debris flows from Prospect Canyon. We used 232 historical photographs, of which 121 were replicated, and ${ }^{14} \mathrm{C}$ and ${ }^{3} \mathrm{He}$ dating methods to reconstruct the ages and, in some cases, the magnitudes of late Holocene debris flows. We quantified the interaction between Prospect Canyon debris flows and the Colorado River using image processing of the historical photographs.

The highest and oldest debris-flow deposits on the debris fan yielded a ${ }^{3} \mathrm{He}$ date of $2.9 \pm 0.6 \mathrm{ka}$ (950 BC), which indicates predominately late Holocene aggradation of one of the largest debris fans in Grand Canyon. The deposit, which has a 25-m escarpment caused by river reworking, crossed the Colorado River and raised its base level by $30 \mathrm{~m}$ for an indeterminate, although probably short, period. We mapped depositional surfaces of 6 debris flows that occurred after 950 BC. The most recent prehistoric debris flow occurred no more than 500 years ago (AD 1434).

From April 1872 to July 1939, no debris flows occurred in Prospect Canyon. Debris flows in 1939, 1954, 1955, 1963, 1966, and 1995 constricted the Colorado River between 35 and 80 percent and completely changed the pattern of flow through the rapid. The debris flows had discharges estimated between about 290 and $1,000 \mathrm{~m}^{3} / \mathrm{s}$ and transported boulders as heavy as 30 $\mathrm{Mg}$. The recurrence interval of these debris flows, calculated from the volume of the aggraded debris fan, ranged from 35 to 200 yrs. The 1939 debris flow in Prospect Canyon appears to have been the largest debris flow in Grand Canyon during the last 125 years.

Debris flows in Prospect Canyon are initiated by streamflow pouring over a 325-m waterfall onto unconsolidated colluvium, a process called the firehose effect. Floods in Prospect Valley above the waterfall are generated during regional winter storms, localized summer thunderstorms, and occasional tropical cyclones. Winter precipitation has increased in the Grand Canyon region since the early 1960s, and the most recent debris flows have occurred during winter storms. Summer rainfall has declined in the same period, decreasing the potential for debris flows in the summer months.

The history of river reworking of the Prospect Canyon debris fan illustrates the interrelation between tributary debris fans and mainstem floods in bedrock canyons. Lava Falls Rapid did not change despite Colorado River floods of $8,500 \mathrm{~m}^{3} / \mathrm{s}$ in 1884 and $6,230 \mathrm{~m}^{3} / \mathrm{s}$ in 1921 . Floods up to $3,540 \mathrm{~m}^{3} / \mathrm{s}$ that occurred after the historical, pre-dam debris flows removed most of the deposits within 3 years. Releases in 1965 from Glen Canyon Dam that were above powerplant capacity but less than $1,640 \mathrm{~m}^{3} / \mathrm{s}$ removed most of the debris fan deposited in 1963 , and the combination of 
dam releases and a 1973 flood on the Little Colorado River removed the 1966 aggradation. About $4,800 \mathrm{~m}^{3}$ of the 1995 deposit was reworked on the day of the 1995 debris flow, dam releases of less than $570 \mathrm{~m}^{3} / \mathrm{s}$ had not reworked the remainder of the aggraded debris fan.

Lava Falls Rapid has been the most unstable reach of whitewater in Grand Canyon during the late Holocene and particularly during the last 120 years. Rapids in bedrock canyons controlled by tributary deposition in the main channel are aggradational features that reflect the net effect of tributary-mainstem interactions. Boulders that form the core of rapids in Grand Canyon are essentially immobile by both regulated and unregulated Colorado River flows. Historical operation of Glen Canyon Dam, which was completed in 1963, has reduced the potential for reworking of debris fans, and has accelerated the rate of net aggradation at the mouths of tributary canyons. Because debris fans that formed after 1963 at Lava Falls have been mostly reworked by dam releases, occasional high releases from Glen Canyon Dam could be scheduled as channel maintenance flows to rework aggraded debris fans.

\section{INTRODUCTION}

Lava Falls on the Colorado River in Grand Canyon (fig. 1) is one of the most difficult navigable rapids in the continental United States (Nash, 1989; Ghiglieri, 1992; Lindemann and Lindemann, 1995). The rapid is located at the mouth of Prospect Canyon at river mile 179.4, or $289 \mathrm{~km}$ downstream from Lees Ferry, Arizona (Stevens, 1990). Lava Falls is the impressive finale for approximately 20,000 river runners who run the Colorado River every year and is the standard against which all rapids in Grand Canyon National Park are judged.

Misconceptions abound in the popular literature concerning the origins, size, and geological significance of Lava Falls Rapid. The first explorers of the Colorado River (John Wesley Powell and Robert Brewster Stanton) believed Lava Falls was formed by the eroded remnants of Pleistocene lava dams that once spanned the inner canyon (Powell, 1875; Smith and Crampton, 1987). Indeed, the rapid is named for the basalt flows that poured over the nearby canyon walls (Granger, 1960; Brian, 1992), and several popular accounts perpetuate the misconception that Lava Falls is controlled by underwater dikes or ledges of basalt (Fradkin,1984, p. 206; Nash 1989, p. 179). Easilyverified details about the rapid such as its fall, about $4 \mathrm{~m}$ (Kieffer, 1988), have been incorrectly reported as $12 \mathrm{~m}$ (Stevens, 1990).
Most of the rapids of the Colorado River, including Lava Falls, result from the accumulation of large boulders in the Colorado River on debris fans at the mouths of tributary canyons (Péwé, 1968; Hamblin and Rigby, 1968; Simmons and Gaskill, 1969; Graf, 1979; Howard and Dolan, 1981; Kieffer, 1987, 1988). Webb and others (1988a) reported that 54 of the 57 largest rapids in Grand Canyon are located at tributary junctures. Most rapids in Grand Canyon are at the mouths of tributary canyons that form along fault zones; the faults typically cross the Colorado River, and the presence of fracture zones downstream of rapids may increase canyon downcutting rates (Dolan and others, 1978).

The locations of some of the smaller rapids and riffles are not at tributary junctures but are linked to reworking of tributary debris fans. Leopold (1969) observed that only a fraction of the rapids are coincident with tributary junctures and that the rapids and pools are evenly spaced and maintained by quasi-equilibrium processes of flow and sediment transport in the Colorado River. Graf (1979) found that the distribution of rapids in Grand Canyon is both regular and random and that 79 percent of the rapids are at tributary junctures. Webb and others (1989) distinguish between primary rapids at tributary junctures and secondary rapids formed around downstream debris bars (Howard and Dolan, 1981); the debris bars are deposits of boulders reworked from the upstream debris fan. 


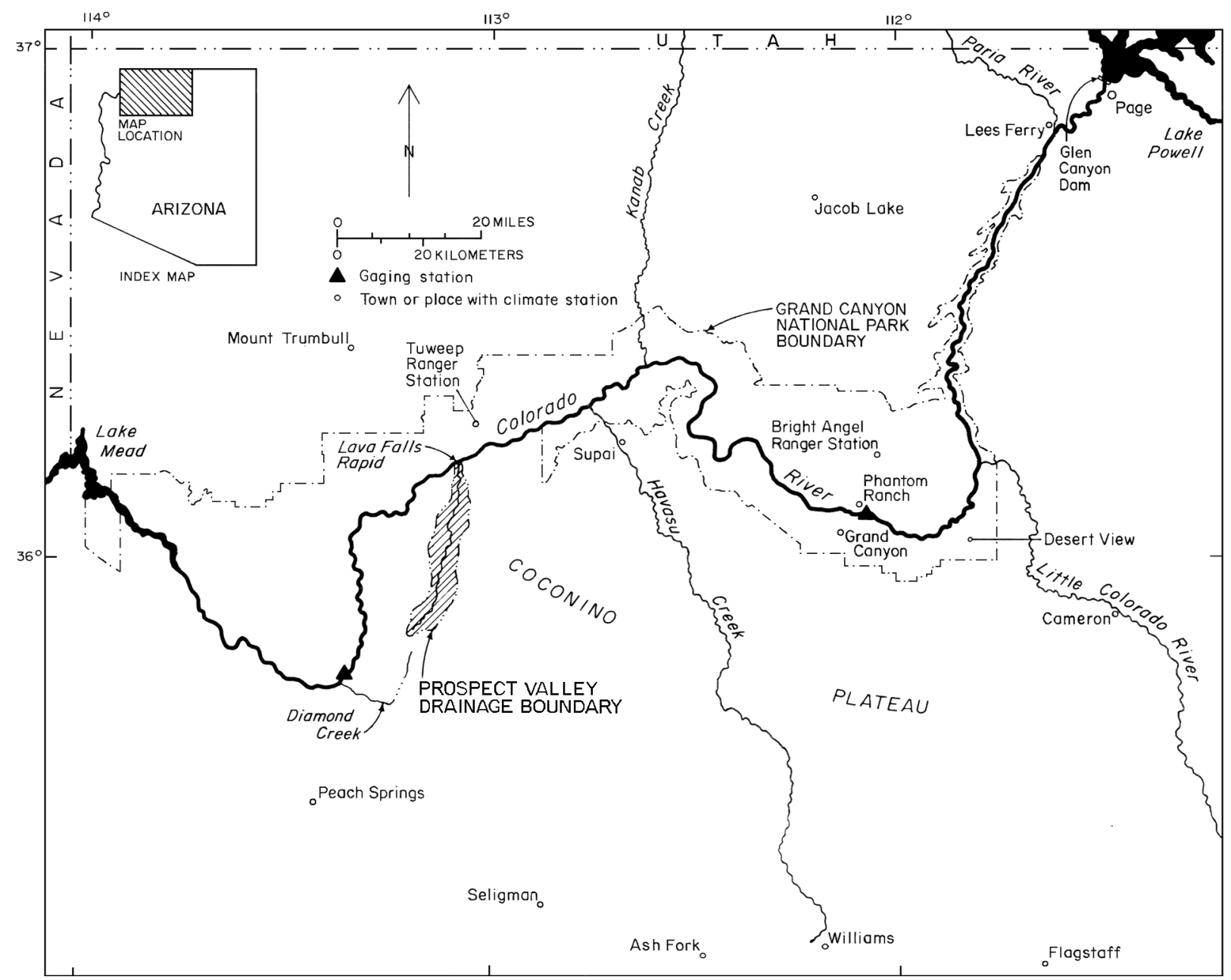

Figure 1. Maps of the study area. A. The Prospect Valley drainage basin and Grand Canyon National Park.

Boulders accumulate in the river by the interacting process of frequent debris-flow deposition and reworking by river floods. Because many rapids occur on regulated rivers, such as the Colorado River in Grand Canyon, the pattern of dam releases strongly affects the stability of rapids (Graf, 1980; Kieffer, 1985; Melis and others, 1994). Rapids have been interpreted as relics of past periods of wetter climate (Graf, 1979) and as landforms that formed prehistorically because of the extreme size of streamflow floods necessary to transport boulders out of tributary canyons (Hamblin and Rigby, 1968). Rapids controlled by debris flows, such as Lava Falls, may be more unstable than other types of rapids because debris flows transport very large boulders into the river relatively frequently.
Using a unique collection of photography (Appendix 1) and Quaternary dating techniques, we demonstrate that Lava Falls is the most unstable rapid in Grand Canyon. Six debris flows from Prospect Canyon have substantially altered Lava Falls Rapid in the 20th century. These debris flows occurred in 1939, 1954, 1955, 1963, 1966, and 1995. We also identified at least six prehistoric and late Holocene debris-flow surfaces. The largest debris flow, which occurred in about $950 \mathrm{BC}$, is the only plausible case of a debris flow having dammed the Colorado River during the late Holocene. Before closure of Glen Canyon Dam in 1963, debris-flow deposits were removed (reworked) within a couple of years by floods in the Colorado River, whereas recently aggraded debris fans have persisted longer. The reworking history of the 


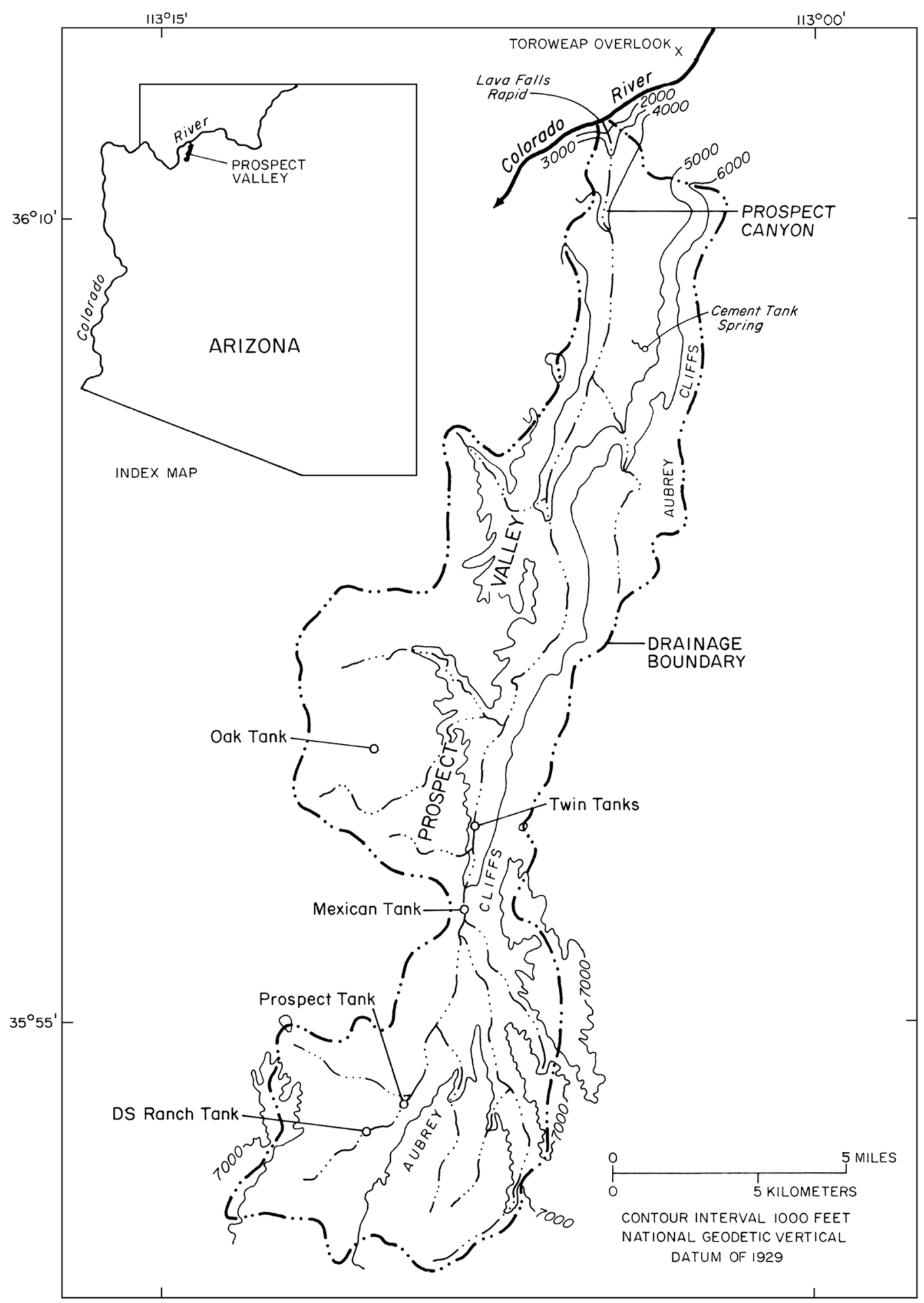

B. The Prospect Valley drainage basin.

Figure 1. Continued. 
Prospect Canyon debris fan illustrates how large dams may be operated to simulate some of the beneficial effects of large floods in unregulated, bedrock-controlled rivers.

\section{Purpose And Scope}

The purpose of this report is to examine the history of debris flows from Prospect Canyon and to document their effect on Lava Falls Rapid. These debris flows, which have occurred more frequently in Prospect Canyon than in other tributaries of the Colorado River in the 20th century, include what probably is the largest debris flow in Grand Canyon history. The detailed history of reworking of the Prospect Canyon debris fan by the Colorado River provides important information on how releases from Glen Canyon Dam may rework aggraded debris fans in Grand Canyon National Park. This work was funded by the Glen Canyon Environmental Studies Program (GCES) of the Bureau of Reclamation.

\section{Acknowledgments}

A large number of people contributed to our reconstruction of the geomorphic history of Lava Falls Rapid. Photographs were obtained with the help of archivists at the National Archives, the Photographic Library of the U.S. Geological Survey, Special Collections at the University of Utah, the Bancroft Library of the University of California at Berkeley, the Utah State Historical Society, Special Collections at Northern Arizona University, the Study Collection at Grand Canyon National Park, the New York Public Library, and the Huntington Library. We greatly appreciated the loan of historical photographs taken by the original photographers: Bryan Brown, Kent Frost, Barry Goldwater, Don Harris, Les Jones, Martin Litton, Gretchen Luepke, Tad Nichols, P.T. Reilly, and Robert Sharp. John Cross II provided invaluable information on changes to Lava Falls following the 1966 debris flow. We especially thank P.T. Reilly of Sun City, Arizona, for allowing us to interpret his invaluable collection of Lava Falls photography.

We thank Nathan Carlton, Dar Crammond, Steve Eudaley, Diane Grua, Jim Hasbargen, Don Jensen, Shirlee Jensen, Terri Mareska, Marker
Marshall, Eric Martin, Tom Martin, Travis McGrath, Elise Pendall, Dave Pratt, Renee Rondeau, Rachel Sobrero, Jessica Stewart, Mike Taylor, Judy Weiss, and Toni Yocum for their valued field assistance. Alan Rigby, Jan Bowers, Thure Cerling, Peter Griffiths, Richard Hereford, Alex McCord, Mimi Murov, Bill Phillips, Betsy Pierson, Kate Thompson, and Kelly Burke contributed valuable technical expertise to this project. Mia Hanson's assistance contributed greatly to all aspects of the project work. Betsy Menand contributed drawings of stratigraphic sections. We especially thank the many photographers who helped in replicating historical photographs of Lava Falls Rapid: Jane Bernard, Tom Brownold, Dave Edwards, Mike Grijalva, Jim Hasbargen, Liz Hymans, Dominic Oldershaw, Steve Tharnstrom, and Raymond M. Turner. The following professional river guides and support personnel contributed their boating skills and knowledge of the river: Jane Bernard, Steve Bledsoe, Gary Bolton, Tom Brownold, Kelly Burke, Michael Collier, Brian Dierker, Dave Edwards, Chris Geneous, Jan Kempster, Kenton Grua, Bob Grusey, Les Hibbert, Liz Hymans, Cindy Krznarch, Archie McPhee, Sue Rhodes, Glenn Rink, Dennis Silva, Drifter Smith, Kelly Smith, Al Tinnes, and Meg Viera. We especially thank Kenton Grua, Bob Grusy, and Kelly Smith for their interpretations of changes in Lava Falls Rapid.

Special thanks to Frank Protiva, Chris Brode, and Mark Gonzales of the GCES survey staff for assistance in preparing the topographic base for Plate I and for estimating areas, volumes, and crosssectional areas for the Prospect Canyon debris fan. Hilary Mayes helped prepare the topographic map of the Prospect Canyon debris fan, and Peter Griffiths and Doug Wellington helped with the analyses of precipitation. Steve Wiele of the U.S. Geological Survey, Boulder, Colorado, supplied travel times for flow in the Colorado River. Dominic Oldershaw printed most of the repeat photographs of Lava Falls Rapid, and Chuck Sternberg drafted the complex figures. Finally, we thank John Elliott, Richard Hereford, and Jack Schmidt for critically reviewing the manuscript. We give special thanks to Dave Wegner, the program manager for GCES, for his unwavering support of our research. 


\section{Characteristics of Debris Flows in Grand Canyon}

Debris flows are water-based slurries of poorlysorted sediments (Costa, 1984) that are a common component of flash floods in Grand Canyon (Webb and others, 1989; Melis and others, 1994). They occur in many different environments ranging from deserts (Blackwelder, 1928; Johnson and Rodine, 1984; Cooke and others, 1993) to montane forests (Sharp and Nobles, 1953; Gallino and Pierson, 1985). Most debris flows occur as a result of destabilization of landscapes by catastrophic events, such as volcanic eruptions (Pierson, 1985; Pierson and Scott, 1985), forest fires (Wohl and Pearthree, 1991; Meyer and others, 1995), or poor land-use practices (Costa, 1984; Johnson and Rodine, 1984). Debris flows less commonly occur in steep terrain, either as a result of rapid glacial melting (Osterkamp and others, 1986) or severe rainstorms (Blackwelder, 1928; Glancy, 1969; Hammack, 1994) at frequencies usually lower than one per decade.

Several classifications of sediment-bearing flows have been proposed on the basis of water content (Beverage and Culbertson, 1964; Pierson and Costa, 1987), depositional characteristics of sediments (Smith, 1986; Scott, 1988), and flow dynamics (Postma, 1986). Two types of waterbased flow occur in Grand Canyon (Melis and others, 1994): streamflow, which contains less than 40 percent sediment by volume, and debris flow, which typically contains more than 80 percent sediment by volume. Although hyperconcentratedflow deposits (Scott, 1988) are recognized in Grand Canyon (Melis and others, 1994), we include this poorly understood process with streamflow in our discussion of flow processes from Prospect Canyon.

In Grand Canyon, historic debris flows typically have a recurrence interval of 10-50 yrs in most tributaries (Melis and others, 1994; Webb, 1996). In contrast, debris flows in Warm Springs Draw in Dinosaur National Monument, Colorado, occur every 200-400 yrs (Hammack, 1994). Howard and Dolan (1976) report that 10 percent of the debris fans they studied (59 total) had significant aggradation between 1965 and 1973. As with any flood process, event frequency is magnitude-dependent, and the presence of channels affects the locus of deposition (Whipple and Dunne, 1992). Osterkamp and others (1986) found that the frequency of "out of channel" debris flows was lower than smaller, channelized events. Hereford and others (1993) differentiated "fan-forming" and "channelized" debris-flow deposits in eastern Grand Canyon. Hereford and others (1996) grouped fan-forming deposits into distinct periods of debrisflow activity in the late Holocene, although they do not report recurrence intervals for specific debris flows. Although most of the debris flows reported by Melis and others (1994) are channelized, leaving little depositional evidence on debris fans, others were fan-forming debris flows that were the largest in the recorded history of Grand Canyon.

Grand Canyon debris flows contain 80-85 percent sediment by volume, and typical debris flows contain from about 2-5 percent clay and 1030 percent sand. The chemistry and mineralogy of silt and clay fraction is very important to sustained flow (Hampton, 1975), and debris flows in Grand Canyon are strongly related to the proximity to terrestrial shale units in the bedrock (Griffiths, 1995). The clay particles in Grand Canyon debris flows are typically illite, kaolinite, and quartz with little smectite (Griffiths, 1995). Boulders that weigh between 1 and $300 \mathrm{Mg}$ are commonly transported to the Colorado River (Melis and others, 1994).

Intense rainfall and slope failures initiate debris flows in Grand Canyon. Total rainfall associated with debris flows has ranged from 27-355 mm (Webb and others, 1989) with intensities up to or exceeding $15 \mathrm{~mm} / \mathrm{hr}$ (Melis and others, 1994; Griffiths, 1995). Storms that cause debris flows typically have recurrence intervals greater than 10 yrs, although daily totals may not be unusual (Griffiths, 1995). Antecedent soil-moisture conditions probably affect debris-flow initiation in Grand Canyon because most historic debris flows occurred during relatively wet periods. Slope failures occur either in bedrock, typically terrestrial shales and mudstones, or in colluvial wedges that mantle steep shelves and ledges. The most common initiation mechanism, called the "firehose effect" by Johnson and Rodine (1984), consists of runoff cascading from limestone cliffs onto colluvial wedges, causing failure (Melis and others, 1994). Debris flows in Grand Canyon tributaries usually 


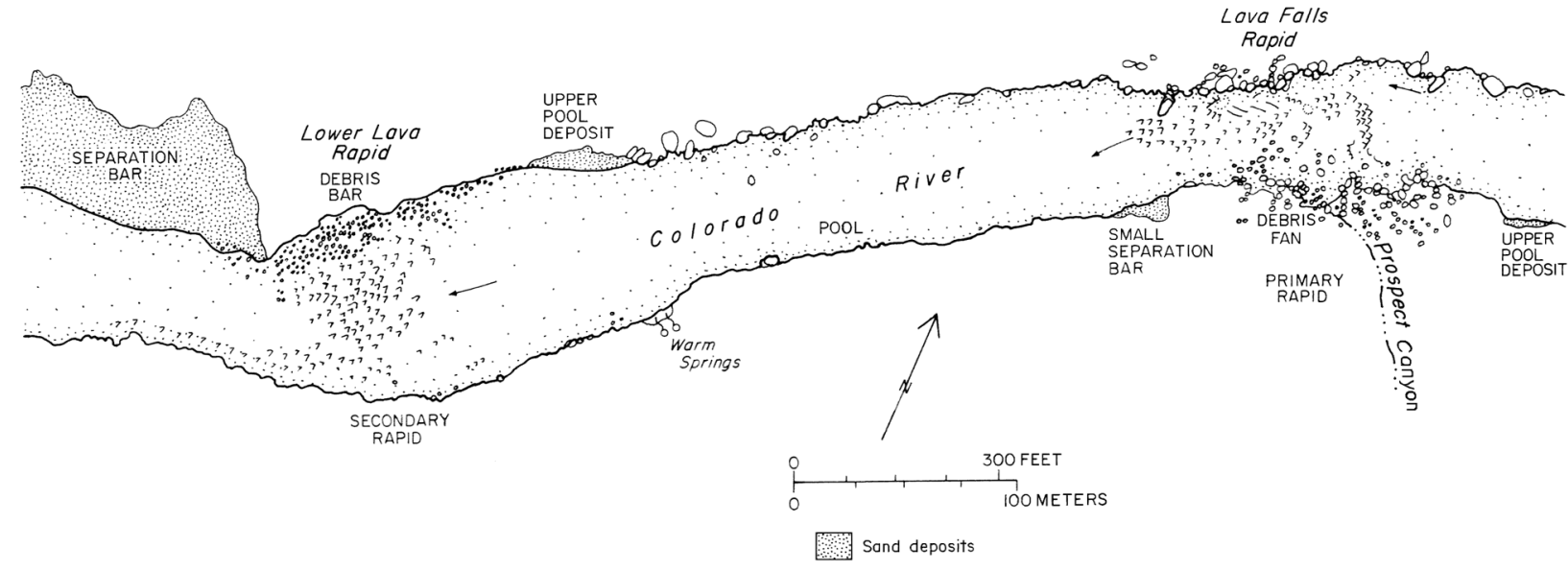

Figure 2. Map of Lava Falls and Lower Lava Rapids showing geomorphic features of the Colorado River. The Prospect Canyon debris fan, shaped and reworked by the Colorado River, forms a rapid-pool-rapid configuration that is typical of Grand Canyon rapids (Webb and others, 1989). The main rapid arises from the constriction and deposition of boulders on the bed of the river. The pool downstream, which has twin eddies, is a recirculation zone (Schmidt and Graf, 1990) that deposits sand bars at certain water levels. Lower Lava Rapid forms from cobbles and boulders that have been eroded from the Prospect Canyon debris fan, transported through the pool, and deposited as the first of a series of alternating debris bars below the rapid.

travel 1 to $20 \mathrm{~km}$ from initiation points to the Colorado River (Melis and others, 1994).

Debris flows in straight, confined channels with relatively low gradients move essentially as plug flow (Johnson and Rodine, 1984) with little internal shearing. In steeper channels, surging flow propagates as waves. In both cases, considerable turbulence and shearing occurs in bends and bedslope transitions. When unconfined, debris-flow slurries deposit levees subparallel to the flow direction. These levees control the location of distributary channels and, in otherwise unconfined areas, allow the slurry to flow over long distances. When debris flows in Grand Canyon reach the Colorado River, they usually decelerate quickly and deposit a debris fan adjacent to or in the river.

Debris-flow transport of very large boulders in low-gradient channels is common throughout the world (Rodine and Johnson, 1976; Johnson and Rodine, 1984; Pierson and Costa, 1987). In Grand Canyon tributaries, boulders with diameters greater than $3 \mathrm{~m}$ are transported in typical debris flows. Debris-flow transport of large boulders is facilitated by three important factors in most Grand Canyon tributaries: 1) the presence of massive limestone and sandstone boulders that accumulate in source areas; 2) the steep gradients of tributary channels; and 3) the relatively short transport distances from source areas to the Colorado River. Most of the boulders that form rapids are transported to the river in debris flows that consist of a single, shortduration pulse of mud and boulders followed by alternating pulses of recessional streamflow and smaller debris flows (Webb and others, 1988a; Webb and others, 1989). In contrast, tributary streamflow floods generally carry finer sediments consisting mainly of sand with cobbles or small boulders as the largest particles transported.

\section{Debris Flows and the Colorado River}

Debris flows in Grand Canyon have several important effects on the Colorado River that are well illustrated at Lava Falls Rapid (fig. 2). Deposition of a debris fan in the river creates a rapid by constricting the width of the river and raising its bed elevation (Howard and Dolan, 1981). Local features, such as unusually large boulders or arrangement of boulders on the bed, cause spectacular hydraulic features that impede navigation. Finally, boulders reworked from the debris fan are redistributed in an orderly fashion downstream, creating secondary rapids or riffles. 
Repeated debris-flow deposition alters the configuration of existing rapids and their controlling debris fans (Webb and others, 1989). This configuration typically forms recirculating flow (eddies) downstream from debris fans that facilitate deposition of sand bars (Howard and Dolan, 1981; Schmidt, 1990; Schmidt and Graf, 1990; Schmidt and Rubin, 1995). The unregulated Colorado River periodically widened constricted rapids by eroding boulders and debris-flow matrix from debris fans (Kieffer, 1985). Reworked debris fans developed residual surfaces composed of boulders lying near their original depositional sites and sand deposited by the Colorado River (Howard and Dolan, 1981). Because debris-fan constrictions and individual boulders cannot be totally removed by the regulated river, many rapids, including Lava Falls, have become more severe during the last 30 years (Graf, 1980; Melis and others, 1994; Webb, 1996).

During the reworking process, sediment eroded from the debris fan, particularly cobbles, is deposited on downstream debris bars. Debris bars are either low-water islands or alternating bars and have well sorted and imbricated gravel, cobbles, or boulders. Debris bars commonly form secondary rapids downstream of the larger, primary rapids at tributary mouths. One such secondary rapid Lower Lava - is about $200 \mathrm{~m}$ downstream from Lava Falls Rapid (fig. 2). Other secondary rapids are common in Grand Canyon, particularly below major rapids such as Hance, Granite, and Crystal (at river miles 77, 93.5, and 98.3, respectively; Stevens, 1990).

\section{METHODS}

\section{The Prospect Valley Drainage Basin}

In remote northwestern Arizona, names commonly are lacking for stream channels and other drainage features. The drainage basin that contributes to the Colorado River at Lava Falls Rapid is one example. The valley leading to Lava Falls (fig. 1b) was named Prospect Valley by prospectors in need of a landmark in the late 19th century (Granger, 1960; Brian, 1992); the watercourse is unnamed. The Prospect Valley drainage basin consists of $257 \mathrm{~km}^{2}$ of forests, grasslands, and desert scrub south of Grand Canyon (fig. 1a) and is the ninth largest of 529 debris-flow producing tributaries in Grand Canyon (Melis and others, 1994). Although the highest point in the drainage basin is $2,367 \mathrm{~m}$, most of the upper part of the drainage lies between 1,450 and 1,950 m.

Prospect Valley drains northward and abruptly changes into a small, steep lower basin informally called Prospect Canyon (fig. 1b). The transition is a 325-m fall in a horizontal distance of approximately $250 \mathrm{~m}$. The rocks exposed in Prospect Canyon consist of Paleozoic sedimentary strata and Quaternary basalts extended from local vents (fig. 3). The Toroweap Fault, which is downthrown to the west, trends south across the Colorado River and through Prospect Canyon (Billingsley and Huntoon, 1983; Jackson, 1990a, 1990b). The drainage of Prospect Valley and Prospect Canyon formed along and to the west of the axis of this fault. The upper Paleozoic strata of Grand Canyon is exposed in the Aubrey Cliffs, which line the east side of Prospect Valley and the Toroweap Fault (fig. 3).

Prospect Valley formed when Quaternary basalt flows filled the ancestral Prospect Canyon during the Pleistocene (Hamblin, 1994b). Basalt flows, which occurred from 1.2 Ma to $140 \mathrm{ka}$, formed dams across the Colorado River with lakes that reportedly extended upstream to Moab, Utah (Hamblin, 1990). Pleistocene lava flows and dams were present at both Lava Falls and Whitmore Wash (river mile 188). One lava flow that originated near Whitmore Wash extended at least $137 \mathrm{~km}$ down the Colorado River (Hamblin, 1994b). Prospect Canyon was filled by a lava flow that also produced the Prospect Dam (Hamblin, 1990, 1994b). Prospect Canyon occupies part of the former canyon, which reached the Colorado River upstream of the current mouth. The waterfall separating Prospect Valley from Prospect Canyon is the discontinuity between the two segments of the drainage basin that causes the abrupt change in fluvial process from streamflow in Prospect Valley to debris flow in Prospect Canyon.

Debris flows in Prospect Canyon are generated during floods in Prospect Valley that pour sufficient quantities of water over the waterfall onto 


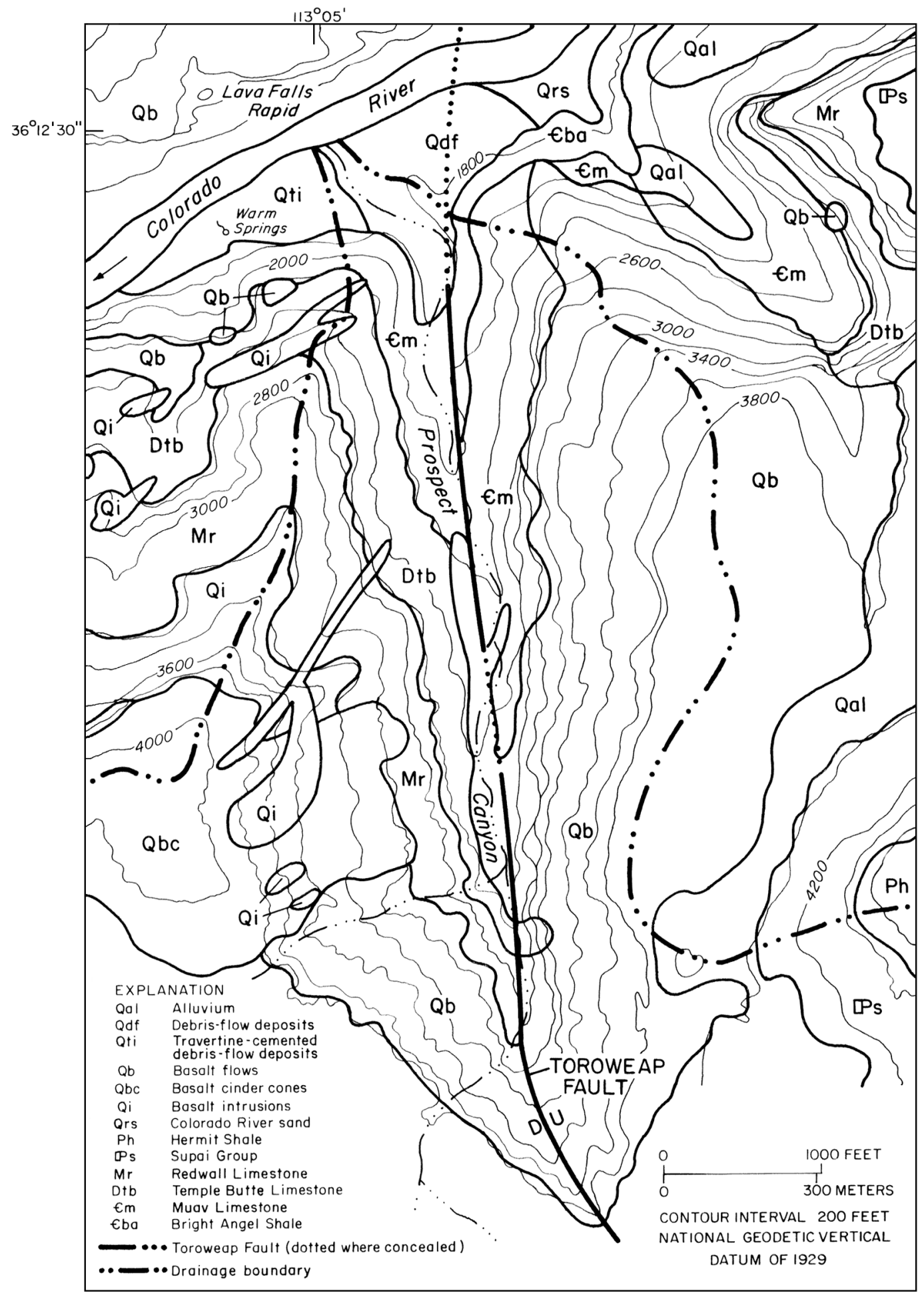

Figure 3. Geologic map of Prospect Canyon. This map is modified from Billingsley and Huntoon (1983) and Hamblin (1994b); the original scale is $1: 62,500$. 
unconsolidated colluvium ("the firehose effect"; Johnson and Rodine, 1984). There is no evidence of past debris flows on the floor of Prospect Valley; stratigraphic evidence of debris flows begins at the foot of the fall into Prospect Canyon. Although the gradient of Prospect Valley (0.041) is relatively low in comparison to other Grand Canyon tributaries, the gradient through Prospect Canyon (0.315) is steep enough to provide considerable potential energy for debris flows. The largest sources of colluvium are rockfall from a headwardly-eroding cinder cone on the western rim and talus from the steep slopes of Prospect Canyon (fig. 3). Both sources provide abundant unconsolidated colluvium that can be mobilized into debris flows.

\section{Historical Photographs of Lava Falls Rapid}

Repeat photography is the most important tool we used to document 20th century debris flows in Prospect Canyon. Numerous photographs and movies have been made of Lava Falls Rapid, beginning with stereoscopic views made by the Powell Expedition in 1872 (Stephens and Shoemaker, 1987). Every expedition on the Colorado River had a photographer, and the downstream view from Toroweap Overlook, which towers $1,000 \mathrm{~m}$ above the river on the northwestern rim of the canyon (fig. 1b), is frequently photographed. We examined 232 historic views of Lava Falls Rapid made between 1872 and 1984 (Appendix 1), which include 48 oblique aerial views, 17 vertical aerial photographs, 129 views taken at or near river level, and 38 views from Toroweap Overlook. We replicated 121 of these photographs from February 1990 to March 1995.

The photographs of Lava Falls Rapid were not taken uniformly in time. Photographic coverage is sparse from 1872 through 1938, when commercial river running began (Lavender, 1985). Photographs are available for 18 dates from 1872 through 1939, or 14 of 68 years; these photographs were taken primarily by parties conducting scientific exploration and surveys of the river. Because river running was a luxury during World War II, only 12 photographs were available from the period 19401947. Beginning in the 1950s, the photographic record of Lava Falls expanded greatly as a new generation of river-runners began running the Colorado River. Photographs are available for 30 dates in the 1950s and 29 dates in the 1960s. Although many photographs are taken every year of Lava Falls during commercial river trips, few recent photographs are commonly available. Vertical aerial photography is available for several years from 1980 through 1995, but vertical photographs were only used to document the effects of the 1995 debris flow.

\section{Mapping and Age Determinations for Debris-Flow Deposits}

Between 1990 and 1994, we surveyed the Prospect Canyon debris fan, produced a topographic map, and mapped the surficial geology (Plate I). Our map of the Prospect Canyon debris fan (Plate 1) delineates geomorphic surfaces, not deposits as depicted on other surficial geology maps of parts of Grand Canyon (Hereford, 1996). Some of the surfaces on the Prospect Canyon debris fan have complex depositional histories that are adequately expressed mappable deposits, in particular surfaces that appear to be terraces with snouts or push-out lobes of potentially different ages on top. The geomorphic surface map also allows delineation of colluvial and reworking processes that could not be distinguished on a deposit map.

We surveyed approximately 1,400 points between 1991 and 1993 to develop our topographic base map. These data were combined with 1:2,400 digital contour data calculated from 1990 aerial photography. The 1990 data have a horizontal accuracy of $\pm 1.3 \mathrm{~m}$ and a vertical accuracy of \pm 0.25 $\mathrm{m}$ on flat slopes and $\pm 1 \mathrm{~m}$ on steep slopes (F. Protiva, GCES, written commun., 1996). Absolute elevation and topographic control needed to combine the two sets of data was obtained using a global positioning system (GPS) with a horizontal and vertical accuracy of $\pm 0.4 \mathrm{~m}$, owing to discrepancies between the 1990 control points and subsequent GPS measurements. Contours were

1. Use of product names is for identification purposes only and does not imply endorsement by the U.S. Geological Survey 
calculated using Terramodel for DOS software ${ }^{1}$. Surficial geology was mapped on an enlarged aerial photograph taken in October 1989 and transferred to the base map. Differentiation of surfaces, particularly those deposited in the 20th century, was facilitated with historical photography (Appendix 1), which allowed differentiation and assignment of small surfaces to specific events.

In general, the Prospect Canyon debris fan is composed of two distinct types of debris-flow surfaces and several types of deposits related to other processes. The oldest and highest deposits form the overall shape of the debris fan, and following Hereford and others $(1993,1996)$ and Hereford (1996), we refer to these as fan-forming debris-flow deposits. Subsequent erosion cut the current channel through the debris fan, giving rise to depositional sites for inset debris-flow deposits. Inset deposits are similar to those termed channelized debris flows by Hereford and others (1993), although the magnitude of the Prospect Canyon debris flows appears to be considerably larger. Other surfaces arise from colluvial processes and reworking by the tributary and (or) the Colorado River.

The age of deposits on the Prospect Canyon debris fan is inherently difficult to determine in the absence of direct evidence such as historical photography (Webb and others, 1989). Although some researchers have ${ }^{14} \mathrm{C}$-dated abundant charcoal in debris-flow deposits owing to forest fires (Meyer and others, 1995) or proximity to archaeological sites (Hereford and others, 1996), organic carbon is rare in most debris-flow deposits in Grand Canyon. We used age-dating techniques ranging from correlation of soil morphology to analysis of radiometric isotopes. Several of these techniques particularly ${ }^{3} \mathrm{He}$ and ${ }^{14} \mathrm{C}$ analyses - yielded absolute dates, whereas other techniques were used to establish relative ages or to distinguish or correlate discontinuous deposits.

\section{Pedogenic Calcium Carbonate}

Soils on the oldest surfaces are weakly developed but contain pedogenic calcium carbonate, which is reflective of the age of the soil and the underlying deposit (Birkeland, 1984). The greatest accumulation of $\mathrm{CaCO}_{3}$ in soils on the
Prospect Canyon debris fan is Stage I carbonate morphology (see Machette, 1985, for a description of carbonate stages) with a maximum accumulation at about $0.50 \mathrm{~m}$ depth. In hot desert soils, this amount of accumulation generally occurs in surfaces deposited in the latest Pleistocene or Holocene (table 2 in Machette, 1985). Hereford and others (1996) also used soil carbonate to differentiate the ages of debris flows in Grand Canyon.

McFadden and Tinsley (1985) developed a model of carbonate accumulation in desert soils. Their model of soil-forming processes is not completely appropriate given the semiarid and hot conditions of the Prospect Canyon debris fan; nonetheless, results indicate substantial carbonate deposition in Holocene soils. In the case of a semiarid, thermic climate, results indicate a maximum carbonate accumulation at 0.25 to $0.70 \mathrm{~m}$ depth for soils about 3,000 years old. Therefore, debris-flow deposits on the Prospect Canyon debris fan with Stage I carbonate accumulation are probably of Holocene age.

\section{${ }^{3} \mathrm{He}$}

The ${ }^{3} \mathrm{He}$ age-dating procedure is reviewed in Cerling and Craig (1994) and has been widely applied to basalt flows with olivine phenocrysts (Cerling and others, 1994). Use of the ${ }^{3} \mathrm{He}$ dating techniques is appropriate for the Prospect Canyon debris fan because isolated olivine phenocrysts or xenoliths occur in two of the dam-forming basalt flows in Prospect Canyon, particularly the Prospect Dam flow that plugs Prospect Canyon (Hamblin, 1994b). Cosmic-ray bombardment of olivine at the surface of basalt clasts produces ${ }^{3} \mathrm{He}$, which is retained within the dense crystalline structure of olivine (Poreda and Cerling, 1992).

The Prospect Canyon debris fan is an ideal setting for estimating ages of deposits using ${ }^{3} \mathrm{He}$. Basalt clasts on the debris fan mostly are from the Prospect Dam flows that form a near-vertical wall at the head of the narrow Prospect Canyon (fig. 3). Cosmogenically produced ${ }^{3} \mathrm{He}$ in the massive basalt is minimal because the lava flows are shielded by high cliffs in the narrow canyon. Slope failures that cause debris flows produce unexposed basalt boulders, and the short transport distance 
between source and debris fan $(1.6 \mathrm{~km})$ suggests little opportunity for long-term exposure of boulders in the channel. Moreover, surface erosion after deposition, which produces anomalously young cosmogenic dates (Cerling and Craig, 1994), is minimal on the Prospect Canyon debris fan because of its coarse particle-size distribution.

\section{Desert Plant Assemblages}

Desert vegetation on the Prospect Canyon debris fan, which is similar to the common vegetation assemblages of the Mojave Desert (Phillips and others, 1987), was used to estimate relative ages of surfaces. Webb and others (1987, 1988b) and Bowers and others (1996) have shown that the species composition of desert vegetation on debris-flow deposits is related to the age of the deposit. Long-lived species such as creosote bush (Larrea tridentata), for example, do not become established until several centuries after the surface formed. The proportion of long-lived versus shortlived species increases consistently on progressively older geomorphic surfaces (Webb and others, 1988b; Bowers and others, 1996).

\section{Clonal Rings of Creosote Bush}

Creosote bush forms clonal rings (Vasek, 1980) that are indicative of the age of the surface that the plant is growing on. As a creosote bush ages, the center of the root crown dies and the outer segment of the root crown splits into genetically identical clones. The ring that forms continues to expand radially at the average rate of $0.66 \mathrm{~mm} \mathrm{yr}^{-1}$ (Vasek, 1980). The diameter of a creosote bush clonal ring, therefore, reflects the establishment date for the plant and gives a minimum age for the surface on which it is growing.

${ }^{14} \mathrm{C}$

We also tested and used radiocarbon $\left({ }^{14} \mathrm{C}\right)$ analyses to date debris flow-deposits on the Prospect Canyon debris fan. We collected various types of organic debris, including pieces of driftwood and small twigs, from the top of several debris-flow surfaces. The "best" samples appeared to be fine-grained organic debris wrapped around or pinned beneath cobbles and boulders in debris-flow levees. No organic material was observed at depth in the debris-flow deposits. The resulting radiocarbon dates were converted to calendar ages using computer routines (Stuiver and Becker, 1993; Stuiver and Reimer, 1993).

${ }^{14} \mathrm{C}$ analyses indicated a substantial residence time for organic debris in the drainage (table 1). Driftwood collected from the surfaces of historic debris-flow levees was radiocarbon dated to determine the association of organic material with the date of the debris flow that transported it. Driftwood on top of the 1939 deposit yielded a calendar date range of AD 1327-1638 (table 1). Three samples of driftwood and twigs on the 1955 deposit correspond to calendar age ranges of $\mathrm{AD}$ 1259-1438, 1410-1954, and 1488-1955, respectively. Two samples of twigs from the undifferentiated 1963/1966 deposits provided postbomb ${ }^{14} \mathrm{C}$ activities that correspond to calendar date ranges of AD 1963 or 1969 and 1962 or 1974 , respectively. Driftwood deposited by the 1993 flood and the 1995 debris flow had post-bomb ${ }^{14} \mathrm{C}$ activities that correspond to a calendar dates of $\mathrm{AD}$ 1959, 1961, or 1981 and 1958 or 1995, respectively (table 1).

The ${ }^{14} \mathrm{C}$ analyses indicate that organic materials are only rarely from Prospect Canyon. This is not surprising, because Ferguson (1971) found persistence of driftwood for as long as a thousand years along the mainstem Colorado River. Webb (1996) documented snags in Grand Canyon that remained standing 400-500 yrs after the tree died. Both the 1939 and 1955 debris flows transported wood that was significantly older than the known date of the transporting debris flow. ${ }^{14} \mathrm{C}$ ages on prehistoric debris flows may be as much as 700 yrs older than the event. Although post-bomb radiocarbon dating has been shown to be relatively reliable in past flood studies (Baker and others, 1985), our results confirm the unreliability of some types of organic debris in post-bomb ${ }^{14} \mathrm{C}$ analyses (Ely and others, 1992). Because data on the most recent debris flows are closer to the true age, we speculate that several debris flows may be required to flush most of the organic debris from the drainage. 
Table 1. Radiocarbon dates of organic material collected from debris-flow deposits at the mouth of Prospect Canyon

\begin{tabular}{|c|c|c|c|c|c|}
\hline Surface & Sample number & $\begin{array}{c}\text { Type of organic } \\
\text { material }\end{array}$ & $\begin{array}{c}\text { Radiocarbon date } \pm \\
1 \text { SD }\end{array}$ & Calendar date (AD) & $\begin{array}{c}2 \sigma \text { range in date } \\
\text { (AD) }\end{array}$ \\
\hline $\begin{array}{c}\text { tif } \\
\text { (Prehistoric) }\end{array}$ & GX-19925 & wood & $485 \pm 90$ & 1434 & $1296-1640$ \\
\hline $\begin{array}{c}\text { tig } \\
(1939)\end{array}$ & GX-19326 & wood & $460 \pm 75$ & 1439 & $1327-1638$ \\
\hline \multirow[t]{3}{*}{$\begin{array}{c}\text { tih } \\
(1955)\end{array}$} & GX-19320 & wood & $365 \pm 90$ & $\begin{array}{c}1494,1601 \\
1616\end{array}$ & $1410-1954$ \\
\hline & GX-19324 & twigs & $190 \pm 95$ & $\begin{array}{c}1674,1779 \\
1801,1943 \\
1954\end{array}$ & $1488-1955$ \\
\hline & GX-19325 & wood & $635 \pm 80$ & $\begin{array}{c}1319,1369 \\
1386\end{array}$ & $1259-1438$ \\
\hline tii & GX-19321 & twigs & $153.8 \pm 1.5 \mathrm{PMC}$ & 1963 or 1969 & n.a. \\
\hline$(1963-66)$ & GX-19322 & twigs & 141.1 \pm 1.1 PMC & 1962 or 1974 & n.a. \\
\hline $\begin{array}{l}\text { rwc } \\
(1993)\end{array}$ & GX-19323 & twigs & $127.7 \pm 1.3 \mathrm{PMC}$ & $\begin{array}{c}1959,1961 \\
\text { or } 1981\end{array}$ & n.a. \\
\hline $\begin{array}{c}\text { tij } \\
(1995)\end{array}$ & GX-20788 & twigs & $117.5 \pm 1.0 \mathrm{PMC}$ & 1958,1995 & n.a. \\
\hline
\end{tabular}

Notes: All ${ }^{14} \mathrm{C}$ analyses were performed by Geochron Laboratories. The raw dates are in years before 1950 (yrs BP), except for those labelled with PMC (percent of modern carbon), which are post-1950. All raw values are \pm 1 standard deviation. Calendar age and $2 \sigma$ range are calculated using the calibration curves presented in Stuiver and Becker (1993) and incorporated in a computer program (Stuiver and Reimer, 1993). The range in age for post-1950 ${ }^{14} \mathrm{C}$ ages is very small. n.a. -- not applicable.

\section{Climatic and Hydrologic Data}

No climate stations are in the Prospect Valley drainage basin. Stations in the Grand Canyon region (fig. 1) are from 40 to $100 \mathrm{~km}$ from the center of the drainage (Appendix 2). Two of the stations-Tuweep Ranger Station and Grand Canyon National Park - have recording rain gages and report hourly precipitation (e.g., U.S. Department of Commerce, 1966). These stations have mean annual precipitation that ranges from 216 to $646 \mathrm{~mm}$; the average of the 8 stations is 334 $\mathrm{mm}$. About 45 percent of precipitation in the Grand Canyon region occurs in winter (November-March) and 43 percent occurs in summer (July-October).

Seasonal precipitation was standardized following an existing technique (Hereford and Webb, 1992) to examine the effects of antecedent soil moisture on debris-flow initiation. We identified the two seasons of summer (July September) and winter (November - March). Values for winter were considered part of the following year; for example, the standardized seasonal precipitation for November 1995 through March 1996 falls in 1996. For each climate station (Appendix 2), we calculated the seasonal standardized precipitation, $\mathrm{P}_{\mathrm{S}}$, by

$$
\mathrm{P}_{\mathrm{S}}=\sum\left[\left(\mathrm{x}_{\mathrm{i}}-\mu_{\mathrm{i}}\right) / \sigma_{\mathrm{i}}\right] / \mathrm{N}
$$

where $\mathrm{x}_{\mathrm{i}}=$ annual seasonal rainfall for climate station $\mathrm{i} ; \mu_{\mathrm{i}}=$ the mean and $\sigma_{\mathrm{i}}=$ the standard deviation of seasonal rainfall for climate station $\mathrm{i}$; and $\mathrm{N}=$ the number of climate stations with data.

We estimated the probability of daily precipitation and storms for known or probable dates of debris flows (Appendix 3). We considered the duration of a storm to be the number of consecutive days with rainfall irrespective of the number of sources of precipitable moisture. We used a modified Gringorten plotting position (U.S. Water Resources Council, 1981):

$$
\mathrm{p}=((\mathrm{m}-0.44) /(\mathrm{n}+0.12)) \cdot \mathrm{d},
$$

where $p=$ probability of the event, $m=$ the ranking of the event, $\mathrm{n}=$ the number of days in the record, 
and $\mathrm{d}=$ the number of days in the season. The recurrence interval, $\mathrm{R}$ (yrs),

$$
\mathrm{R}=1 / \mathrm{p} .
$$

Streamflow data were obtained for two gaging stations on the Colorado River (fig. 1): the Colorado River near Grand Canyon, Arizona (09402500; Garrett and Gellenbeck, 1991) and the Colorado River above Diamond Creek near Peach Springs, Arizona (09404200; unpublished data). Flood frequency for the Colorado River near Grand Canyon was estimated using the log-Pearson type III distribution (U.S. Water Resources Council, 1981). Data from the gaging station above Diamond Creek were used to estimate discharges in the Colorado River immediately after the 1995 debris flow using a travel time of 9 hrs (S. Wiele, written commun., 1995).

Streamflow is not measured in either Prospect Valley or Prospect Canyon. On the basis of regional regression equations (Region 10; Thomas and others, 1994), we estimated the streamflow flood frequency for Prospect Valley. The estimated 2-yr flood is only $6 \mathrm{~m}^{3} / \mathrm{s}$, but the estimated 50 - and 100 year floods are 500 and $800 \mathrm{~m}^{3} / \mathrm{s}$, respectively. The actual long-recurrence interval discharges may be less than the estimated discharges in Prospect Canyon because of attenuation of flow through the meandering, braided channel of Prospect Valley. Also, the main channel and its tributaries are dammed by six small stock tanks (fig. 1b), which would reduce runoff reaching Prospect Canyon.

\section{Characterization of Debris Flows and Debris Fans}

Particle-size distributions for debris-flow surfaces and fresh debris-flow deposits were estimated using several techniques (Melis and others, 1994). Point counts were made every 1-2 m, depending on the size of particles, along a tape stretched across the surface; the sizes of all particles greater than $2 \mathrm{~mm}$ b-axis diameter were recorded. In a test pit dug in the 1995 debris-flow deposit, we recorded all particles greater than $16 \mathrm{~mm}$ collected from a $1 \mathrm{~m}^{3}$ volume. In most cases, a sample was collected and dry sieved to determine the distribution of smaller particles. Point count and sieve data were combined by distributing the data obtained by sieve analysis over the percentage of particles less than $16 \mathrm{~mm}$ determined by point counts. We use the standardized size classes for sediment (Friedman and Sanders, 1978), except we prefer the term gravel to pebbles for particles between 2 and $64 \mathrm{~mm}$ diameter.

The source geologic units for particles was evaluated for all point counts and simplified to the types of basalt, sandstones from the Supai Group, Redwall Limestone (which includes Temple Butte Limestone), Muav Limestone, and undifferentiated limestone, which includes Kaibab Limestone, limestones from the Supai Group, and indistinct particles from the Redwall, Temple Butte, and Muav Limestones. All particles that could not be classified by lithology are termed unknown source.

We estimated the weight of the largest boulders on the debris fan and several debris-flow surfaces (Appendix 4). An arbitrary number of boulders -usually 10 -- that appeared to be the largest were measured depending upon shape. For example, we measured 3 dimensions for rectangular particles but only 1 diameter for spherical particles. We then calculated the volume of the particle and estimated its weight using a density of $2,650 \mathrm{~kg} / \mathrm{m}^{3}$ for limestone and sandstone and $2,700 \mathrm{~kg} / \mathrm{m}^{3}$ for basalt (Appendix 4).

\section{Discharge Estimates and Water Content}

We estimated the discharge of three Prospect Canyon debris flows from depositional evidence along or upstream of section A - A' (Plate I). The surface of a moving fluid typically rises on the outside of the bend and drops on the inside of the bend. The difference in flow elevation between the inside and outside of bends, which is attributable to centrifugal forces exerted on the fluid mass, is termed "superelevation" (Apmann, 1973). The mean velocity $\left(V_{S}\right)$ is related to the difference between the flow elevations on the outside and inside of the bend by

$$
\mathrm{V}_{\mathrm{s}}=\left(\mathrm{g} \cdot \mathrm{R}_{\mathrm{c}} \cdot \Delta \mathrm{H}_{\mathrm{s}} / \mathrm{W}\right)^{0.5}
$$

where $g=$ acceleration due to gravity $\left(9.8 \mathrm{~m} / \mathrm{s}^{2}\right)$, $\mathrm{R}_{\mathrm{c}}=$ the radius of bend curvature along the channel's centerline $(\mathrm{m})$, and $\Delta \mathrm{H}_{\mathrm{s}}=$ the elevation 
difference at the point of maximum superelevation (m). We estimated discharges using

$$
\mathrm{Q}=\mathrm{A} \cdot \mathrm{V}_{\mathrm{S}},
$$

where $\mathrm{A}=$ cross-sectional area in square meters. Webb and others (1989) and Melis and others (1994) report significant overestimation of discharge using $\mathrm{V}_{\mathrm{s}}$ and the area of the cross section in the bend. To obtain $\mathrm{A}$, the water surface described by $\Delta \mathrm{H}_{\mathrm{S}}$ is assumed linear, although it is likely non-linear (S-shaped). Therefore, we used the cross-sectional flow area slightly downstream from A - A' where $\Delta \mathrm{H}_{\mathrm{s}} \approx 0$.

We estimated the water content of the less than $16 \mathrm{~mm}$ fraction by gradually adding water to a $5 \mathrm{~kg}$ sample in a laboratory tray and observing its flow properties (Melis and others, 1994). Samples from debris-flow deposits typically exhibited debrisflow behavior over a 1-2 percent range in water content, whereas samples from hyperconcentratedflow deposits did not exhibit debris-flow behavior at any water content.

Unit stream power is estimated from

$$
\omega=\gamma \cdot Q \cdot S / T
$$

where $\omega=$ the stream power per unit width of channel, $\gamma=$ the unit weight of the flow, $Q=$ the discharge, $\mathrm{S}=$ the energy slope of the flow, and $\mathrm{T}=$ the width of the flow. For a debris flow, the value of $\gamma$ is a function of water content and particle-size distribution.

\section{Surface Area and Volume}

The volume of sediment deposited by Holocene and historic debris flows was estimated using a combination of surveys, photographic rectification, and slope projection. Some deposits, such as the debris fan in 1993 and 1995, were surveyed and areas and volumes were calculated from digitalelevation models. The debris fans of 1954, 1955, 1963, and 1964 are recorded in historical obliqueaerial photographs (figs. 21, 24). We used surveyed control points and the Map and Image Processing

2. Use of product names is for identification purposes only and does not imply endorsement by the U.S. Geological Survey
Software (MIPs) ${ }^{2}$ to rectify oblique aerial and ground photographs and measure depositional areas. We estimated the accuracy of rectified images to be about $\pm 1-3$ m horizontally, although the accuracy varies according to the amount of distortion in the photographs.

We used the topographic information in Plate I to reconstruct the area and volume of deposits before reworking by the Colorado River. For debris fans with remnant deposits but no photographic documentation, we projected the slope of the deposit toward the Colorado River until its projected elevation either intersected the watersurface profile of the river at a stage corresponding to $140 \mathrm{~m}^{3} / \mathrm{s}$ or touched the right bank. The assumption of a linear slope is justified by the evenness of the 1995 debris fan and other surfaces, especially surface tfa (Plate I).

The thickness of each debris fan was difficult to determine except for the 1995 debris flow (the debris fan was surveyed in 1993). Thickness was estimated using several techniques. In the case of the 1939 deposit, its existing surface was projected over the 1993 debris fan. Photographic evidence was used to identify points on the 1939 debris fan that were not eroded or buried by the debris flows of 1954, 1955, 1963, and 1966. Also, boulders on the 1872 debris fan that were covered by 20th century debris flows, but not moved by subsequent Colorado River floods, provided minimum thicknesses for the deposits. We could not estimate the accuracy of the estimated thicknesses.

\section{Constrictions}

Historic debris flows from Prospect Canyon constricted the Colorado River substantially at Lava Falls Rapid. Kieffer $(1985,1990)$ defined the constriction ratio, $\mathrm{C}_{\mathrm{r}}$, as

$$
\mathrm{C}_{\mathrm{r}}=\mathrm{W}_{\mathrm{r}} / \mathrm{W}_{\mathrm{u}}(6),
$$

where $\mathrm{W}_{\mathrm{r}}=$ the width of the rapid and $\mathrm{W}_{\mathrm{u}}=$ the channel width upstream of the rapid. According to Kieffer (1990), the average $C_{r}$ for Grand Canyon rapids is 0.50. Similarly, Schmidt (1990) and Schmidt and Graf (1990) report an expansion ratio, which is the ratio of the downstream width to rapid width, for 70 debris fans in eastern Grand Canyon. 
Table 2. Rankings of the area and volume of the largest debris fans of probable Holocene age on the Colorado River in Grand Canyon National Park (T.S. Melis, unpublished data)

\begin{tabular}{|c|c|c|c|c|c|c|}
\hline Debris-fan name & River mile & River side & Area (ha) & Area rank & Volume $\left(10^{6} \mathrm{~m}^{3}\right)$ & Volume rank \\
\hline Kwagunt & 56.0 & $\mathrm{R}$ & 18.4 & 1 & 2.1 & 1 \\
\hline Prospect & 179.3 & $\mathrm{~L}$ & 9.2 & 2 & 1.9 & 2 \\
\hline Palisades & 65.5 & $\mathrm{~L}$ & 7.5 & 3 & 0.96 & 3 \\
\hline Basalt & 69.6 & $\mathrm{R}$ & 7.3 & 4 & 0.48 & 6 \\
\hline Little Nankoweap & 51.7 & $\mathrm{R}$ & 6.6 & 5 & 0.54 & 4 \\
\hline Soap Creek & 11.2 & $\mathrm{R}$ & 6.1 & 6 & 0.52 & 5 \\
\hline Whitmore & 188.1 & $\mathrm{R}$ & 4.9 & 7 & 0.21 & 10 \\
\hline Saddle & 47.0 & $\mathrm{R}$ & 4.2 & 8 & 0.28 & 9 \\
\hline Fossil & 125.0 & $\mathrm{~L}$ & 3.9 & 9 & 0.31 & 7 \\
\hline Forster & 122.7 & $\mathrm{~L}$ & 3.5 & 10 & 0.29 & 8 \\
\hline Malgosa & 57.5 & $\mathrm{R}$ & 2.9 & 11 & 0.19 & 11 \\
\hline 75-Mile & 75.5 & $\mathrm{~L}$ & 2.5 & 12 & 0.11 & 18 \\
\hline Unnamed & 189.7 & $\mathrm{~L}$ & 2.4 & 13 & 0.18 & 13 \\
\hline Unnamed & 49.6 & $\mathrm{~L}$ & 2.4 & 14 & 0.14 & 15 \\
\hline Unnamed & 49.8 & $\mathrm{R}$ & 2.4 & 15 & 0.18 & 12 \\
\hline \multicolumn{7}{|l|}{$\ldots$} \\
\hline Crystal & 98.2 & $\mathrm{R}$ & 1.9 & 19 & 0.09 & 22 \\
\hline
\end{tabular}

Notes: All values are for debris fans above about $140 \mathrm{~m}^{3} / \mathrm{s}$ discharge in the Colorado River and only include the area of debris-flow deposition. Areas of sand-bar deposition, debris bars, and colluvial deposits are not included. Debris fans reported in Hereford and others (1996) in eastern Grand Canyon are not included, with the exception of the Palisades Creek debris fan, which is of Late Holocene age. The Unkar and Comanche debris fans, which would probably rank 2 and 3 in terms of area, may be mostly of Pleistocene age.

$\mathrm{C}_{\mathrm{r}}$ is not a totally satisfactory measure of constrictions because $\mathrm{C}_{\mathrm{r}}$ decreases as the amount of constriction increases. Another measure of the narrowing of rapids is the percent constriction, $\mathrm{C}_{\mathrm{w}}$, which is

$$
\mathrm{C}_{\mathrm{W}}=\left[1-\mathrm{W}_{\mathrm{r}(\text { ave })} \cdot\left(1 / \mathrm{W}_{\mathrm{u}}+1 / \mathrm{W}_{\mathrm{d}}\right) / 2\right] \cdot 100
$$

where $\mathrm{W}_{\mathrm{r}(\mathrm{ave})}=$ the average cross section of the constricted channel in the rapid and $\mathrm{W}_{\mathrm{d}}=$ the width downstream of the rapid below the expansion zone. For the maximum $\mathrm{C}_{\mathrm{w}}, \mathrm{W}_{\mathrm{r}(\mathrm{ave})}$ is the narrowest width of the rapid. For a rapid with equal widths above and below the constriction,

$$
\mathrm{C}_{\mathrm{W}}=\left(1-\mathrm{C}_{\mathrm{r}}\right) \cdot 100
$$

The widths upstream and downstream from Lava Falls Rapid are not equal and change with discharge of the Colorado River, in a manner similar to other Grand Canyon debris fans (Schmidt, 1990).

Both $\mathrm{C}_{\mathrm{r}}$ and $\mathrm{C}_{\mathrm{w}}$ vary with stage through a stable rapid. Because river banks typically are steep above and below the rapid, and because the surface of the debris fan typically has a relatively low slope angle, $\mathrm{C}_{\mathrm{w}}$ increases as the discharge decreases below the point where a significant area of the debris fan is exposed. In contrast, $\mathrm{C}_{\mathrm{r}}$ decreases as the river narrows. At Lava Falls Rapid, $\mathrm{C}_{\mathrm{w}}$ increases substantially below a discharge of about 150-200 $\mathrm{m}^{3} / \mathrm{s}$ regardless of the recent depositional history. Because of the uncertainty in image rectification and change in constriction with stage, we rounded $\mathrm{C}_{\mathrm{r}}$ to the nearest 0.05 unit and $\mathrm{C}_{\mathrm{w}}$ to the nearest 5 percent.

\section{SURFICIAL GEOLOGY OF THE PROSPECT DEBRIS FAN}

\section{General Debris Fan Characteristics}

The Prospect Canyon debris fan has a plan area of 9.2 ha and a volume of 1.9 million $\mathrm{m}^{3}$ above the $140 \mathrm{~m}^{3} / \mathrm{s}$ stage of the Colorado River. Of debris 


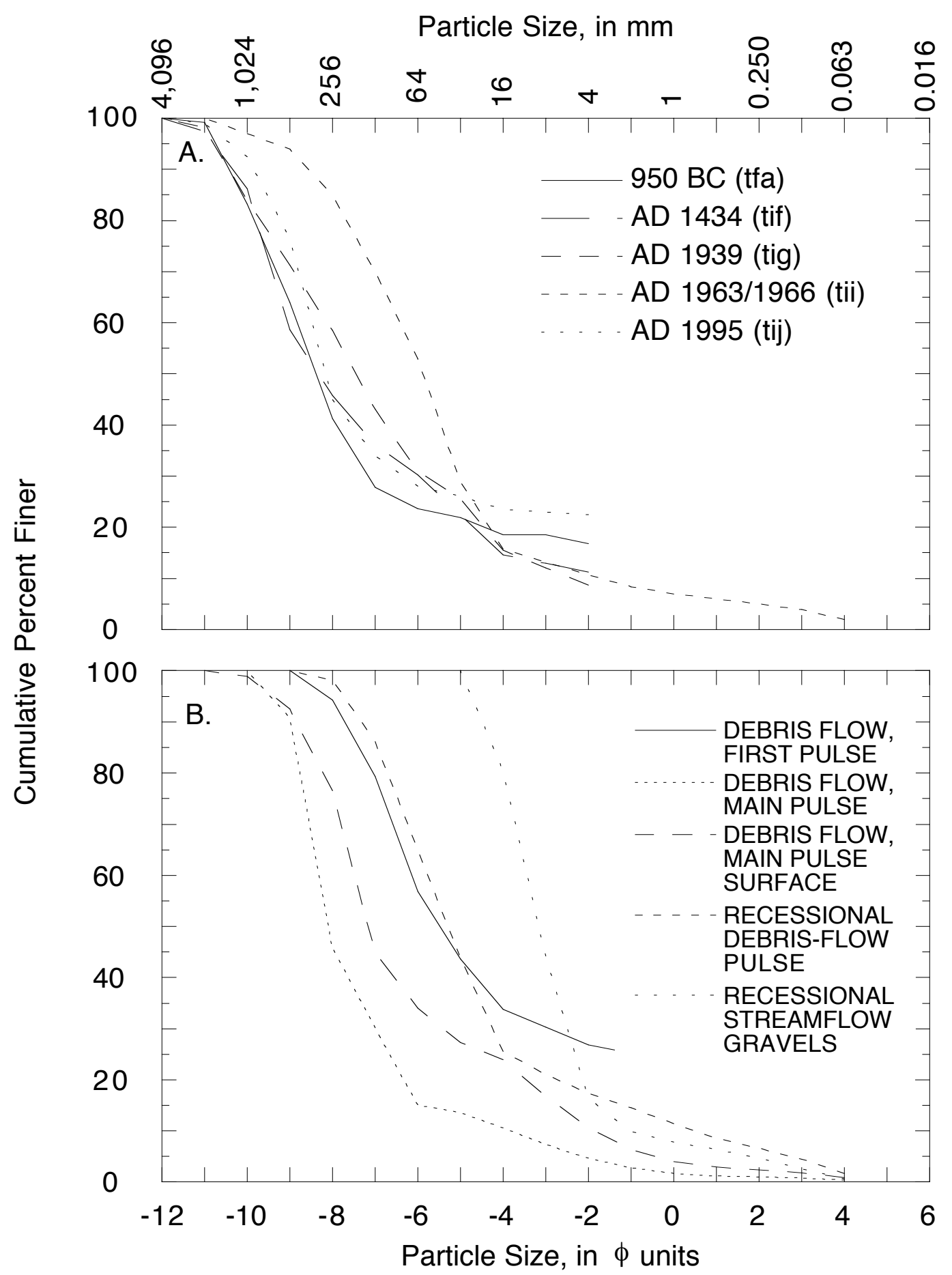

Figure 4. Particle-size distributions for debris flows in Prospect Canyon. A. Prehistoric and historic debris flows. B. Pulses of the 1995 debris flow 
Table 3. Mineralogy of the clay-size fraction of Prospect Canyon debris flows compared with other Grand Canyon debris flows

\begin{tabular}{|c|c|c|c|c|c|c|}
\hline \multirow[b]{2}{*}{ Sample Location } & \multirow[b]{2}{*}{ Illite } & \multicolumn{5}{|c|}{ PERCENT OF PARTICLES } \\
\hline & & Kaolinite & Smectite & Quartz & Carbonate & Other \\
\hline \multicolumn{7}{|c|}{ Grand Canyon debris flows* } \\
\hline Mean & 46 & 28 & 5 & 7 & 5 & 9 \\
\hline SD & 15 & 10 & 12 & 4 & 5 & 13 \\
\hline \multicolumn{7}{|c|}{ Prospect Canyon debris flows } \\
\hline Colluvium & 36 & 24 & 2 & 13 & 21 & 4 \\
\hline AD 1939 & 21 & 28 & 12 & 8 & 18 & 13 \\
\hline AD 1995 & 34 & 38 & 4 & 7 & 15 & 2 \\
\hline
\end{tabular}

Notes: Semi-quantitative clay mineralogy analyses were done by X-ray diffraction techniques and are accurate to $\pm 20 \%$.

* Statistics are for 12 historic debris flows in Grand Canyon (P.G. Griffiths and R.H. Webb, written commun., 1995).

fans of probable Holocene age in Grand Canyon, the Prospect Canyon debris fan has the second largest area and volume; only the Kwagunt Creek debris fan, at river mile 56.0, is larger (table 2). With an average thickness of $28 \mathrm{~m}$, the Prospect Canyon debris fan is the thickest debris fan of probable Holocene age in Grand Canyon. The second highest, the Palisades Creek debris fan (Hereford and others, 1993, 1996), has an average thickness of $13 \mathrm{~m}$. In contrast, the Crystal Creek debris fan, which controls the second most difficult rapid in Grand Canyon (Nash, 1989; Stevens, 1990), ranks 19th and 22nd in area and volume (table 2).

The surficial deposits on the Prospect Canyon debris fan are poorly sorted mixtures of particles that range in size from clay to boulders (fig. 4a). In general, about 10 percent of the deposits from Prospect Canyon debris flows are sand or finer; typically only 1-2 percent of the particles are silt and clay. Debris flows from Prospect Canyon contain less fine-grained material than most debris flows in Grand Canyon, which typically have 5-10 percent silt and clay and 20-30 percent sand (Melis and others, 1994). The coarseness of the debrisflow deposits is caused by the basaltic source material in Prospect Canyon. Much of the sand in Prospect Canyon debris flows is either suspended sediment eroded from Prospect Valley or ash from tuffs or the cinder cone on the west side of Prospect Canyon (fig. 3). The Hermit Shale, which contributes clay to most debris flows in Grand Canyon (Griffiths, 1995), is not exposed in Prospect Canyon and only contribute sediment in runoff from Prospect Valley. Clay particles in Prospect Canyon debris flows are mostly illite and kaolinite, and the mineral abundances are similar to other Grand Canyon debris flows (table 3).

Between 40 and 63 percent of the clasts present in debris flows from Prospect Canyon are Pleistocene basalts (fig. 5). Typical Grand Canyon debris-flow deposits are dominated by clasts from the Redwall Limestone and other Paleozoic units (Melis and others, 1994). The reason for the abundance of basalt is the large amount of Quaternary basalt in Prospect Canyon, especially in the vicinity of the waterfall (fig. 3).

\section{Fan-Forming Debris-Flow Surfaces}

tfa

The highest surface on the Prospect Canyon debris fan (figs. 6, 7) is composed of mid-Holocene, fan-forming debris-flow deposits. The area of this surface, the largest on the debris fan, is 4.38 ha. Although individual lobes and snouts have surface expressions on the surface, the surficial deposits appear to be of uniform age. Internal drainage channels that developed after the debris flow sediments were deposited slightly dissect this surface. The surface is about $15 \mathrm{~m}$ above the channel of Prospect Canyon and $25 \mathrm{~m}$ above the Colorado River at its maximum height (Plate I). Three distinct strata appear in the vertical exposures, each of which represents deposition by an unknown number of debris flows (fig. 8). The lower strata do not have preserved soils at their 


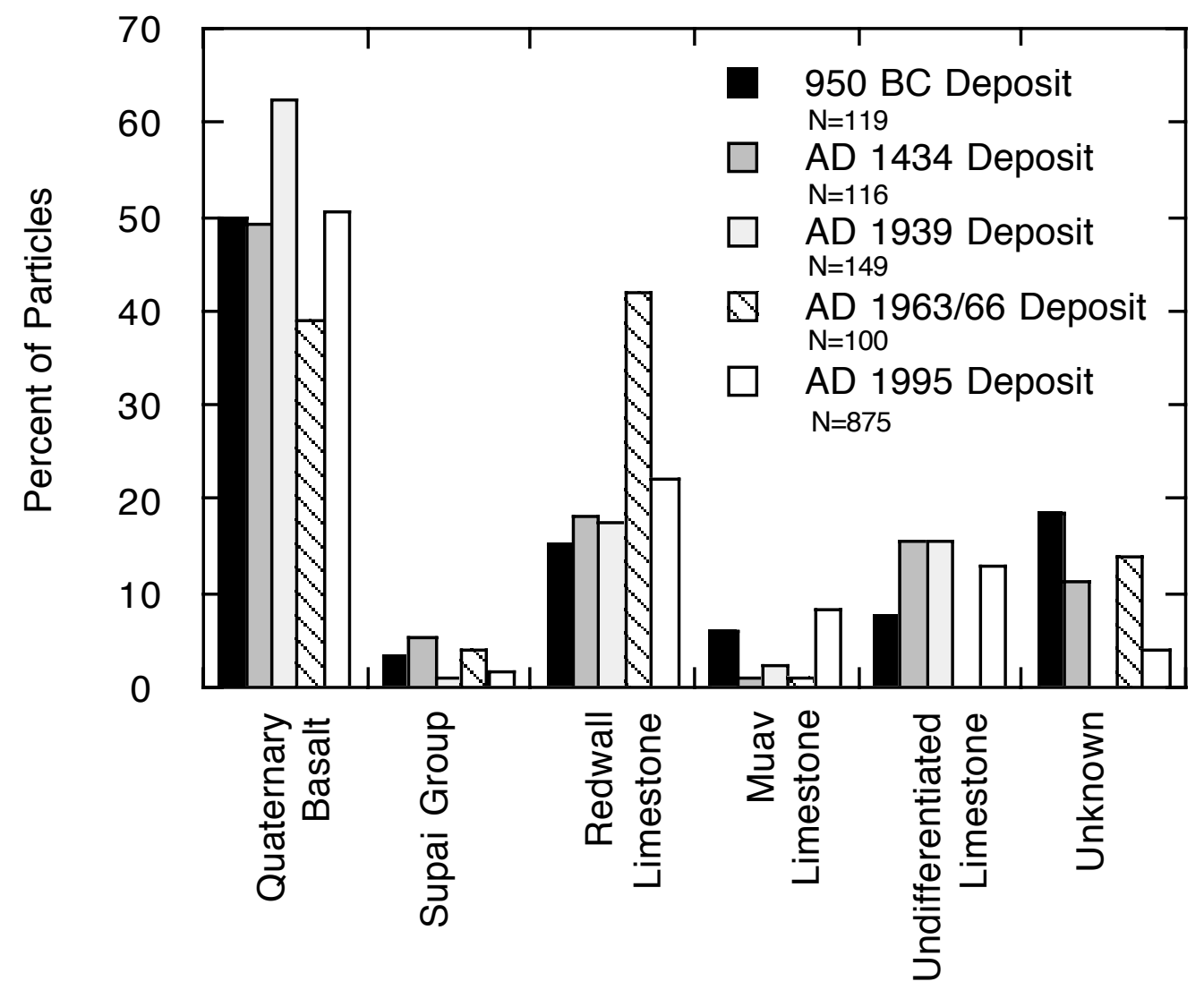

Figure 5. Source materials transported by debris flows in Prospect Canyon.

tops, which suggests that deposition of the main body of the debris fan occurred at a faster rate than soil-forming processes.

Soils are weakly developed on tfa. Desert pavement is not present, and cryptobiotic crusts are common in the fine-grained soil between the boulders. The soil has a thin and weakly developed A horizon, stage I carbonate accumulations on particles in the $\mathrm{C}$ horizons, and no cambic development in the profile. The maximum carbonate accumulation is at $0.50 \mathrm{~m}$ depth. Such soil profile is indicative of a mid-Holocene age for the surface. ${ }^{3} \mathrm{He}$ concentrations in olivine phenocrysts in basalt on surface tfa indicate an age of 2.9 $\pm 0.6 \mathrm{ka}$ (950 BC) (Cerling and others, 1995). The Toroweap Fault crosses the Prospect Canyon debris fan (fig. 3) without a surface rupture (Jackson, 1990a, 1990b). The estimated age of the most recent rupture in Prospect Valley is $3.1 \mathrm{ka}$
(Jackson, 1990a), which suggests that the ${ }^{3} \mathrm{He}$ age is reasonable.

The deposit underlying surface tfa is very poorly sorted with $\mathrm{d}_{50}=0.35 \mathrm{~m}$ (fig. $4 \mathrm{a}$ ) and boulders up to $3 \mathrm{~m}$ in diameter; larger boulders up to $5 \mathrm{~m}$ in diameter have fallen from the surface onto lower surfaces. The larger particles, which are subangular to rounded, consist of basalt (50 percent), limestones ( 25 percent), sandstones from the Supai Group (4 percent), and other rock types (21 percent) (fig. 5). The limestone and sandstone clasts are highly weathered with slight to moderate coatings of desert varnish, and the undersides of basalt clasts have a slight orange coloration.

The desert plant assemblage on surface tfa is dominated by creosote bush with 19 percent cover (Bowers and others, 1996). Mormon tea (Ephedra nevadensis) and Engelmann's prickly pear (Opuntia engelmannii) also contribute significant 


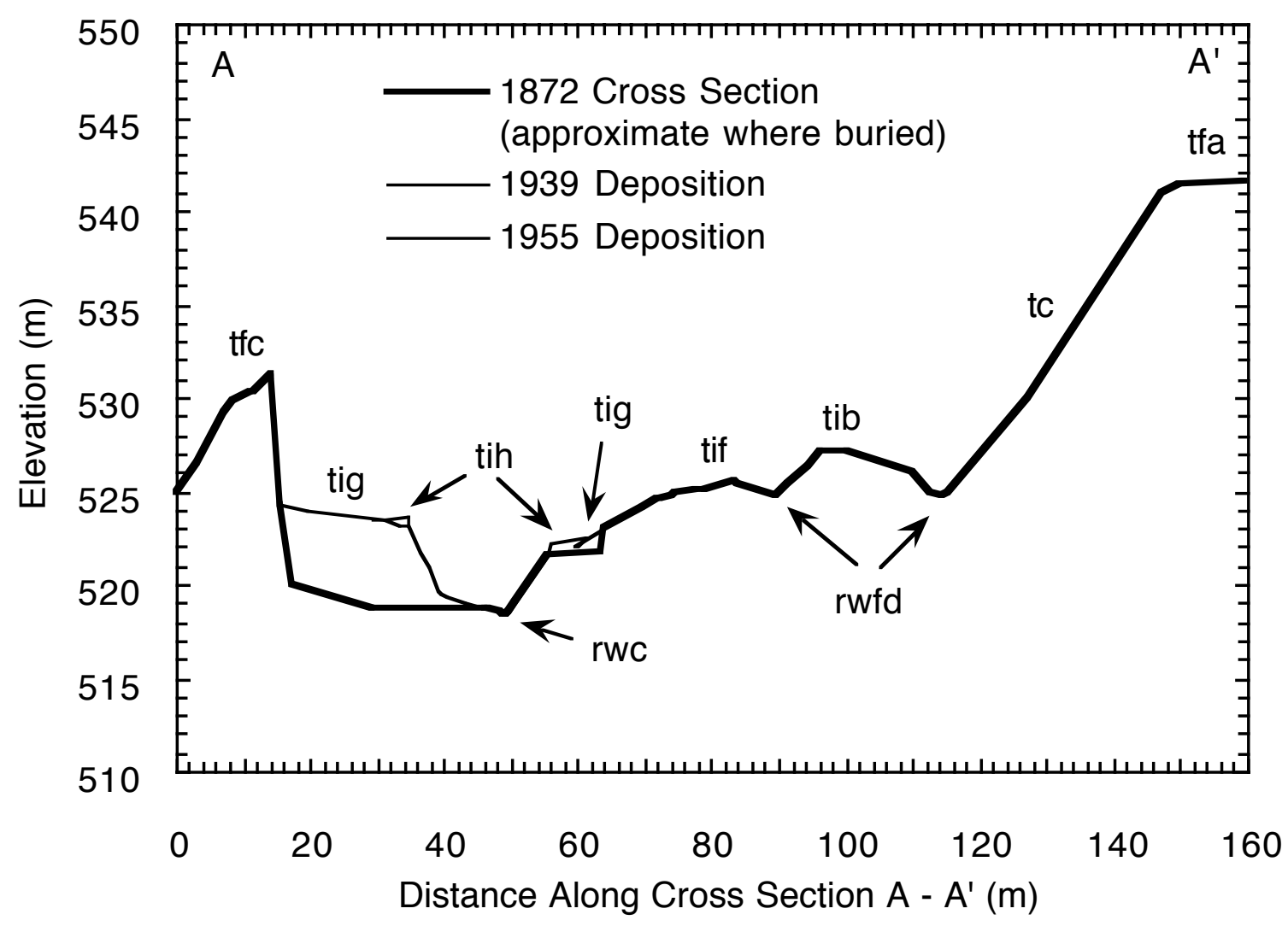

Figure 6. Cross section showing the relative elevations and positions of fan-forming and inset debris-flow surfaces along A - A' (see Plate I).

cover. Barrel cactus (Ferocactus cylindraceous) is very prominent on this and the other fan-forming debris-flow deposits. Creosote bush forms distinct clonal ring-structures between 1.02 and $1.35 \mathrm{~m}$ in diameter on this surface. Using Vasek's (1980) relation, the original plants were established between $\mathrm{AD} 0$ and 500 .

\section{tfb}

Surface $\mathrm{tfb}$ is a poorly defined swale of about 0.15 ha between units tfa and $\mathrm{tfc}$ on the downstream side of the Prospect Canyon debris fan (Plate I). The deposit appears to be the remnant of a late Holocene debris flow that lapped onto and is inset into surface tfa. Exposures of the deposit underlying surface tfb show poorly-sorted sediment; most of the largest particles are cobbles, although some boulders are present. The vegetation on surface $\mathrm{tfb}$ is similar to that on tfa, except that Engelmann's prickly pear forms dense stands at the distal end of the surface.

tfc

This surface is inset against surfaces tfa and $\mathrm{tfb}$ at about the same height (fig. 6). The deposit consists of poorly-sorted sediments with boulders up to $3 \mathrm{~m}$ in diameter. One or more beds of very poorly sorted, subangular to rounded clasts of basalt, limestone, and sandstone are present. Larger clasts have Stage I calcium carbonate coatings. Surface weathering of limestone boulders is less intense on this surface than on tfa, possibly owing to greater surficial erosion on the smaller tfc. The deposit has a vertical exposure of approximately 8 


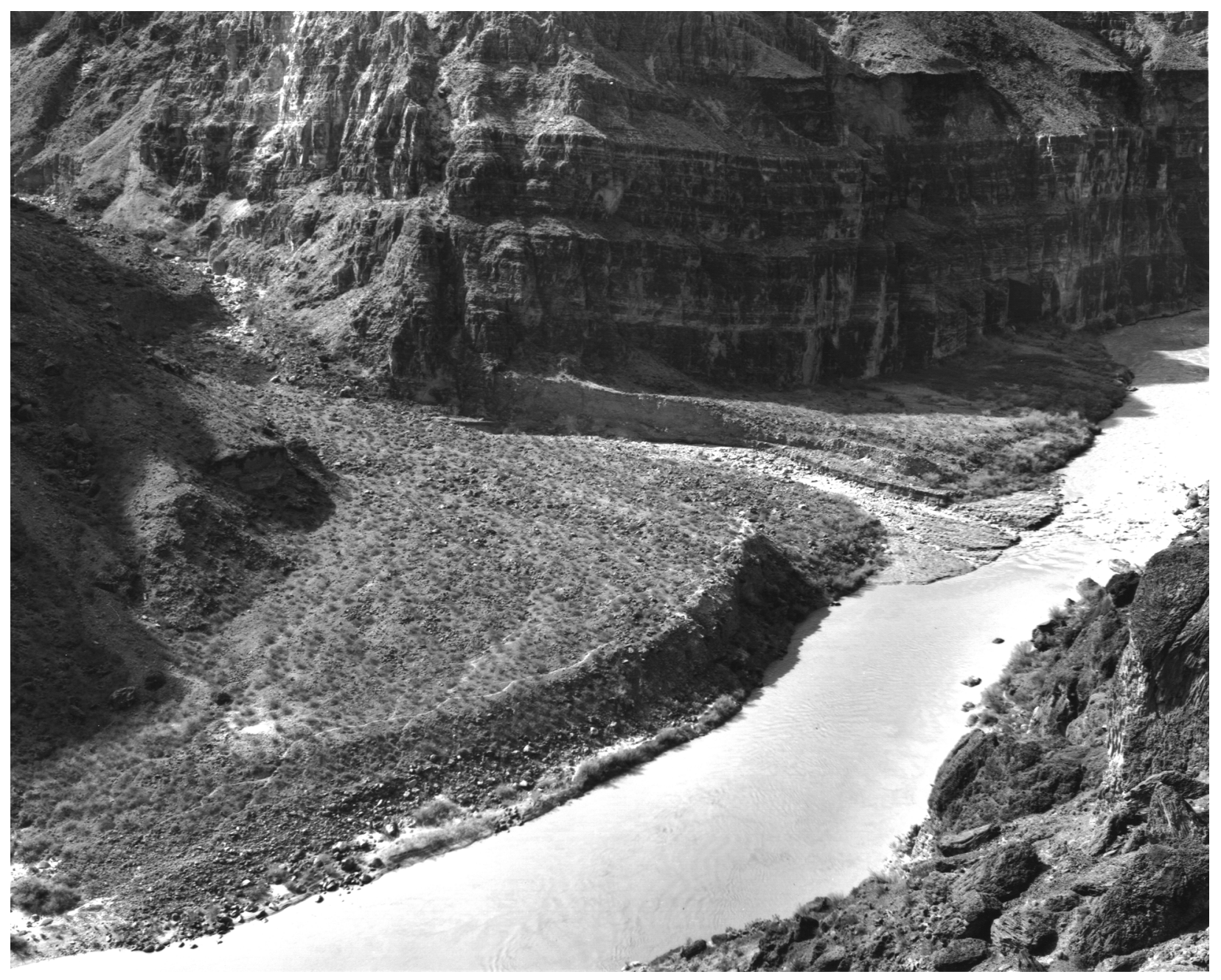

Figure 7. View of the Prospect Canyon debris fan on March 7, 1995 (S. Tharnstrom). Surface tfa dominates the left center of the view. Deposition from the 1995 debris flow appears at right center adjacent to the rapid.

m (fig. 6, Plate I). The desert plant assemblage on this surface, which has an area of only $364 \mathrm{~m}^{2}$, is similar to that on surface tfa.

\section{Inset Debris-Flow Surfaces}

tia

This triangular-shaped remnant of a debrisflow levee is the oldest of the inset debris-flow deposits on the Prospect Canyon debris fan. The surface, which has an area of $800 \mathrm{~m}^{2}$, consists of poorly-sorted deposits with occasional boulders that have fallen from surface tfa. Unlike other inset surfaces, large open areas with fine-grained sediment characterize this surface; cryptobiotic crusts are common. The larger particles are subangular to rounded clasts of moderatelyvarnished basalt and moderately-weathered limestone and sandstone. Most clasts of Redwall Limestone show moderate pitting and some sandstone clasts have disintegrated.

The soil on surface tia has a weak A horizon and Stage I carbonate on clasts similar to surface tfa. Maximum carbonate development is at $0.50 \mathrm{~m}$; below a depth of $1.0 \mathrm{~m}$, carbonate coatings on clasts are very weak. Desert vegetation assemblage is mostly creosote bush with scattered shrubs and barrel cacti; the creosote bush clonal rings range in diameter from 0.60 to $1.50 \mathrm{~m}$, which corresponds to an establishment age of $300 \mathrm{BC}$ to $\mathrm{AD} 1100$.

tib 


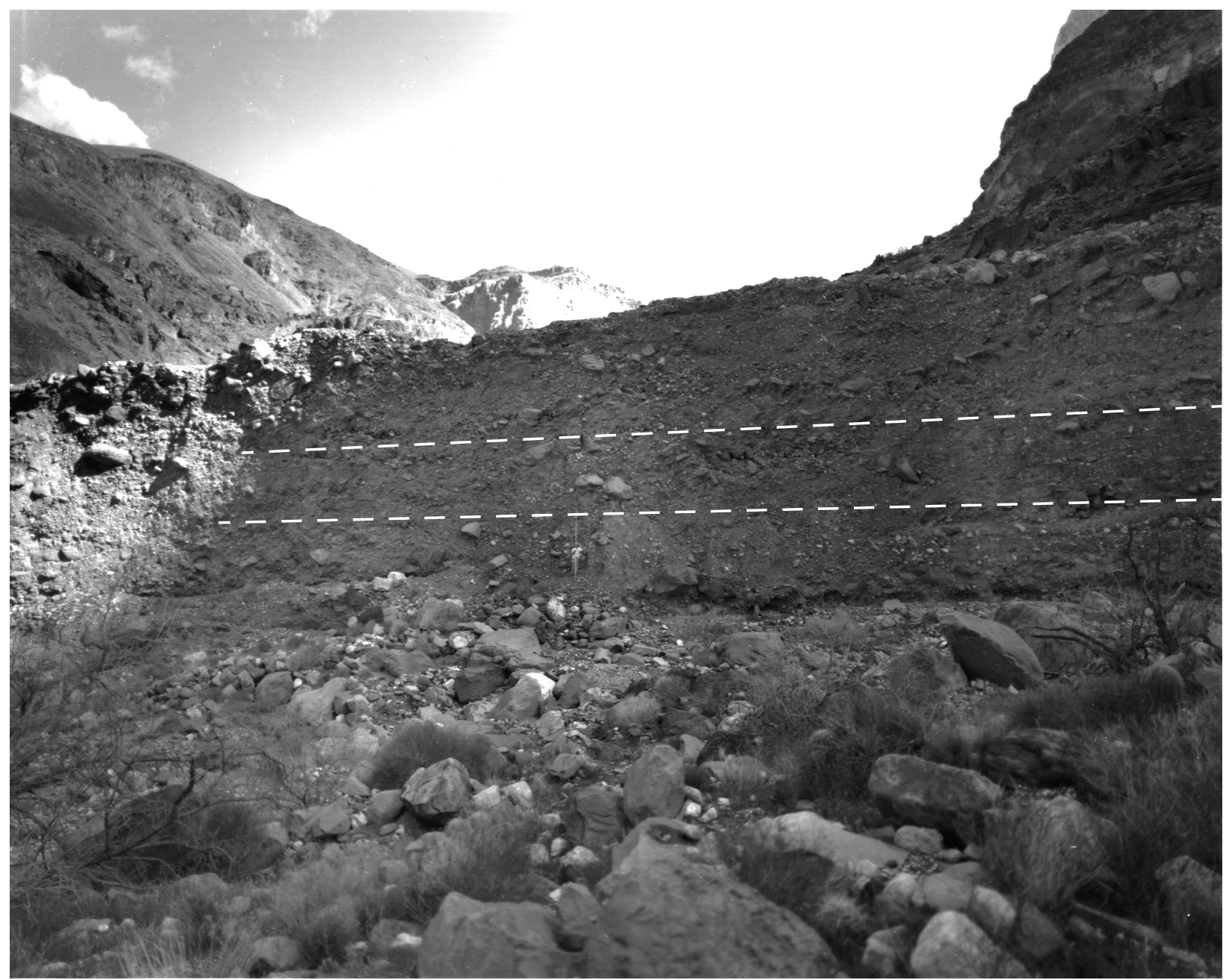

Figure 8. Stratigraphy of surface tfa on the Prospect Canyon debris fan. Dashed lines indicate the approximate contact points between stratigraphic layers.

This surface, with an area of 0.28 ha, is the largest of the inset surfaces of Prospect Canyon (Plate I) and is inset against surface tfa (fig. 6). An internal drainage channel bisects the surface into upstream and downstream segments. The deposit is inset against surface $\mathrm{tfa}$; surfaces tic, tid, and tie are push-out lobes on over surface tib. Sediment is poorly sorted with boulders up to $3 \mathrm{~m}$ in diameter, and larger boulders that fell from surface tfa lie on the surface. Clasts are weathered and varnished slightly less than similar clasts on surface tia and some of these clasts appear to have faint percussion marks. The soil has a weakly-developed A horizon and Stage I carbonate that is similar to the soil developed on tia. Creosote bush dominates the desert plant assemblages, and most of the shrubs appear to be in clonal rings that range between 0.10 and $0.60 \mathrm{~m}$ in diameter. These rings suggests that the creosote bushes became established between AD 1100 and 1800. Mormon tea and California buckwheat (Eriogonum fasciculatum) are common shrubs on this surface, and barrel cacti are particularly large and numerous.

\section{tic}

Surface tic is a large push-out lobe on surface tib and occupies $314 \mathrm{~m}^{2}$ near the apex of the Prospect Canyon debris fan (Plate I). The downslope side of the surface appears to be a relic snout. The soil development and weathering of clasts are similar to surfaces tia and tib. Several of the largest boulders on this surface fell from vertical exposures of surface tfa. Several creosote bushes dominate the vegetation on this small surface and form small clonal rings 0.30 to $0.50 \mathrm{~m}$ in diameter, 


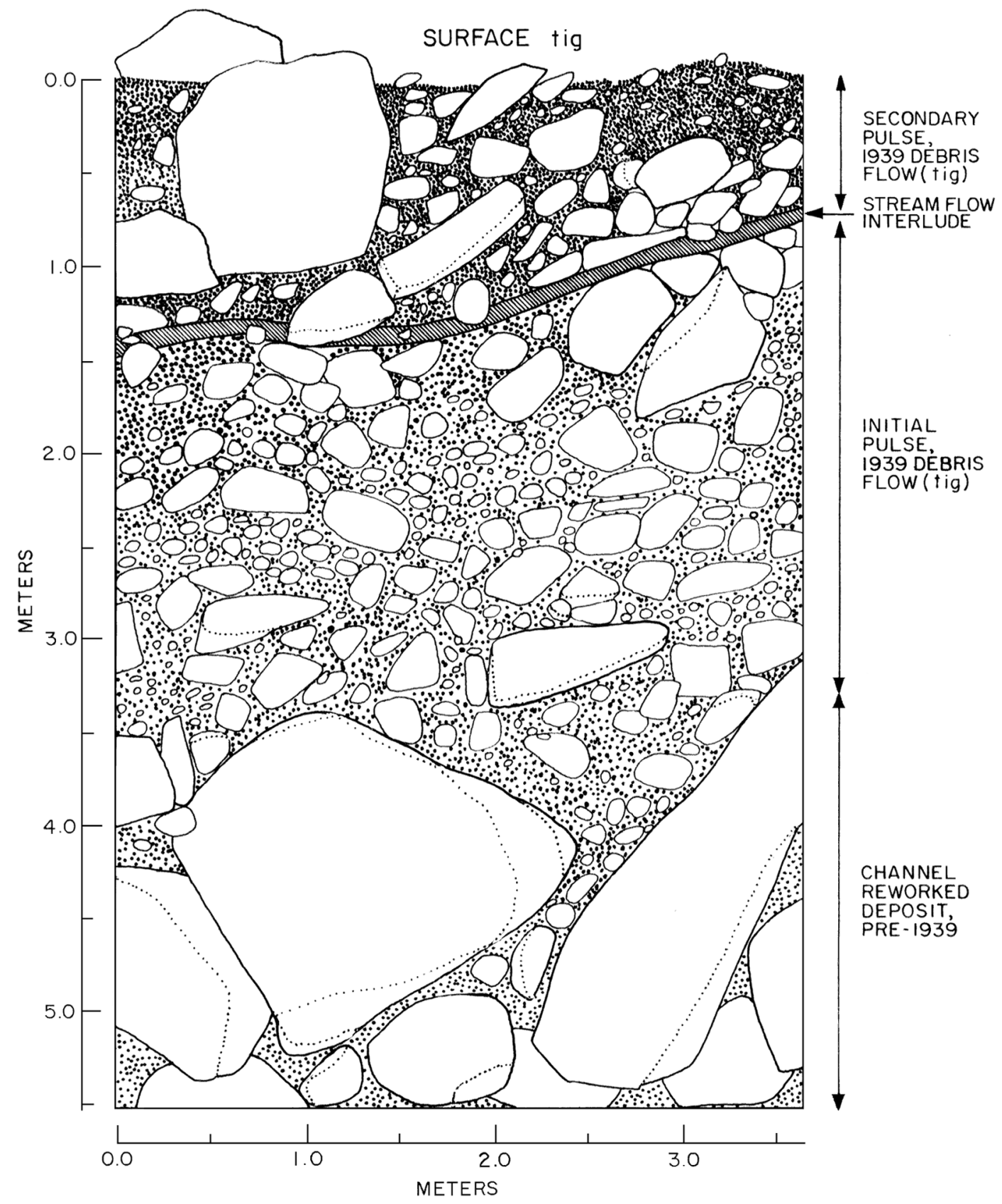

Figure 9. Stratigraphy of the 1939 debris-flow deposit (surface tig). A streamflow deposit of reddish silty sand (thin hatched band) is an intermediate phase of the event, separating the initial pulse (1.5$3.5 \mathrm{~m}$ ) from a secondary pulse $(0-1.2 \mathrm{~m})$. The largest boulders at the bottom have b-axis diameters of 0.75-1.4 m. 


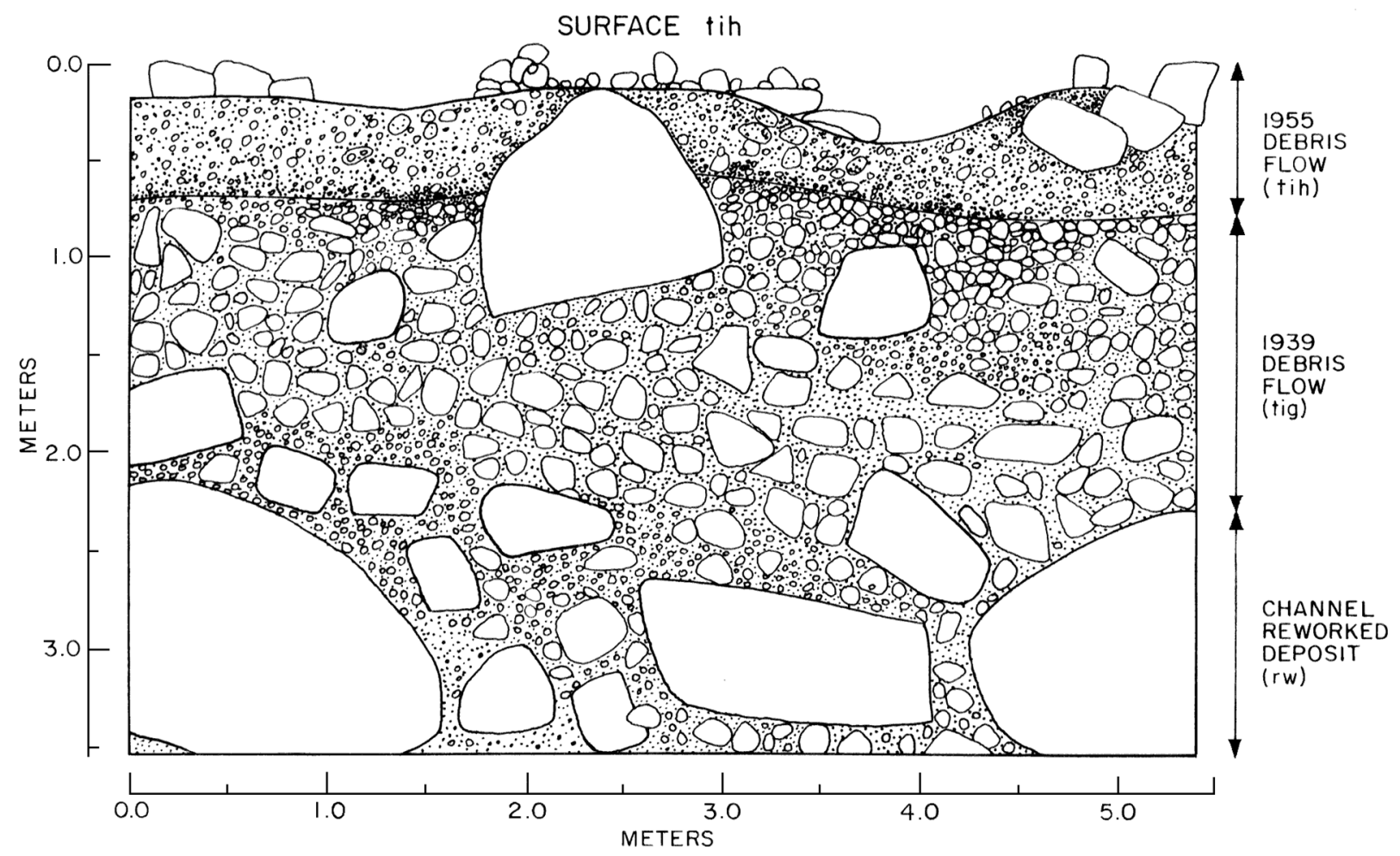

Figure 10. Stratigraphy of the 1955 debris-flow deposits (surface tih). The 1955 debris-flow deposit (0.6-1.0 m thick, tih) overlies the 1939 deposit (0.3-2.0 m thick). Stratigraphic breaks are faint, particularly between the 1939 deposit (tig) and the underlying reworked channel deposits.

which suggests they became established between AD 1240 and 1540.

tid

This small, arcuate surface is on a deposit that overtops surface tic at the apex of the Prospect Canyon debris fan. The morphology of surface tic indicates the deposit is a push-out lobe. On its upstream side, erosion by recent Prospect Canyon debris flows - particularly the 1939 event - have created a vertical exposure of about $4 \mathrm{~m}$. Because of poor sorting, lack of imbrication, and lack of soil development, a stratigraphic break could not be distinguished between surfaces tic and tid. Few plants grow on this surface because it only has an area of $190 \mathrm{~m}^{2}$. Surfaces tic and tid may have been deposited during the same debris flow, but we do not have sufficient evidence to make this conclusion. tie

This small $\left(43 \mathrm{~m}^{2}\right)$, lobate surface overlaps surface tib. The soil properties, surface weathering, and desert varnish on surface tie indicate an age slightly younger than surface tib but perhaps of similar age to tic and tid. The particle-size distribution and source material for this surface are similar to other inset debris-flow deposits. This surface could be contemporaneous with surface tid, but the two surfaces have no distinguishing characteristics, other than their morphology as push-out lobes, to determine their genetic link.

tif

Debris-flow sediments form a prominent surface along the right side of Prospect Canyon (fig. 6) and the downstream side of Lava Falls Rapid. Driftwood collected from under cobbles on surface tif yielded a radiocarbon age of $485 \pm 90$ yrs BP, which corresponds to a calendar date range of $\mathrm{AD}$ 


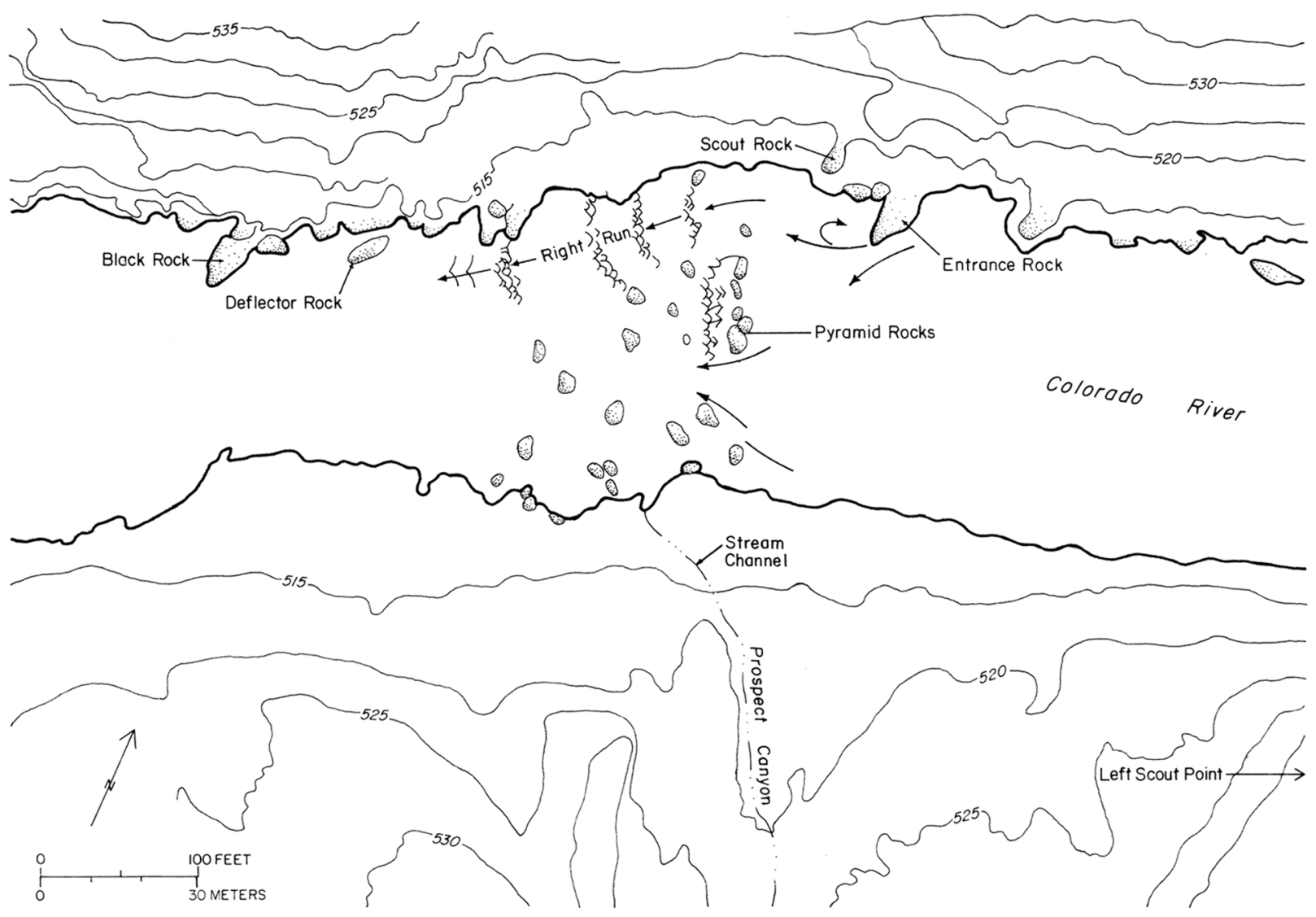

Figure 11. Maps of Lava Falls Rapid. A. Based on a 1994 aerial photograph, taken at a discharge of $234 \mathrm{~m}^{3} / \mathrm{s}$, this map shows the modern configuration of Lava Falls Rapid, which was unchanged from 1973 to 1995 . The Ledge Hole evolved during the 1950s as boulders accumulated in the center of the rapid. The V Wave is initiated by the Meteor Rock, which probably was deposited in September 1939, and by boulders near the right bank. The Big Wave forms by flow over the Deflector Rock, which was rotated and moved downstream during the 1939 debris flow. The Right Run, the most common route, is used at discharges less than $850 \mathrm{~m}^{3} / \mathrm{s}$. The Left Run is only feasible at a discharge greater than about $600 \mathrm{~m}^{3} / \mathrm{s}$, whereas the Slot Run is possible from about $250-450 \mathrm{~m}^{3} / \mathrm{s}$. The 1995 debris flow constricted the rapid by 62 percent, increased the velocity of the Right Run, made the Left Run feasible at lower discharges, and eliminated the Big Wave at most water levels.

1296-1640 and a date of AD 1434 (table 1). The deposit is poorly-sorted with $\mathrm{d}_{50}=0.35 \mathrm{~m}$ (fig. $4 \mathrm{a}$ ) and boulders up to $2.7 \mathrm{~m}$ in b-axis diameter (Appendix 4). Snouts and boulder-strewn levees are prominent on this jumbled surface. About 49 percent of the clasts are basalt and 35 percent are limestone (fig. 5). Boulders are lightly varnished, and percussion marks remain prominent.

The desert plant assemblage reflects the late Holocene age of this surface, which has an area of 0.18 ha. Long-lived catclaw (Acacia greggii) dominates the desert vegetation assemblage with 19.5 percent cover; Mormon tea has 11.5 percent cover (Bowers and others, 1996) and young barrel cacti are abundant. California buckwheat is common around the margins of this deposit, and creosote bush is rare.

\section{tig}

Deposits from the 1939 debris flow form extensive surfaces that are inset against surface tfc on channel left and surfaces tie and tif on channel right of Prospect Canyon (fig. 6). Levee deposits on both the left and right sides of Prospect Canyon have a maximum thickness of about $4 \mathrm{~m}$ and an area of 0.65 ha. Internal drainage between surfaces tig and tib, tic, and tid (Plate I), which has mostly sand and gravel at the surface, was a conduit for recessional flow or dewatering of the 1939 deposit. Deposits from the 1955 debris flow (surface tih) 


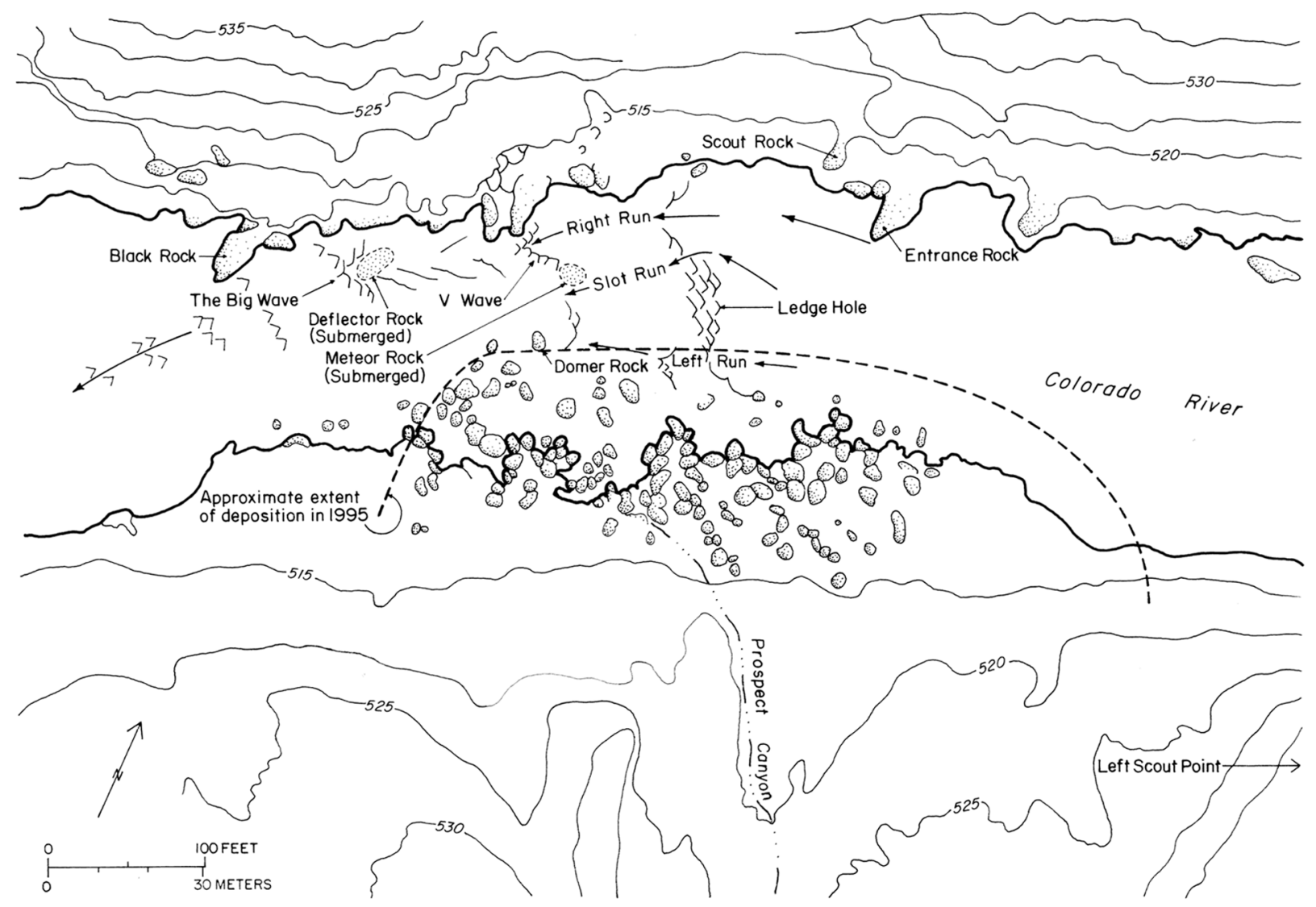

B. The configuration of the rapid from 1872 to 1939 was reconstructed using 37 historical photographs; the water level depicted in the map is about $280 \mathrm{~m}^{3} / \mathrm{s}$. The Pyramid Rocks were prominent near the middle of what is now the entry to the right run; they were exposed at discharges of less than about $500 \mathrm{~m}^{3} / \mathrm{s}$. The Deflector Rock dominated the right side of the rapid and forced flow to the left of the Black Rock. The left side of the rapid was a series of exposed or shallowly submerged boulders, although a second tongue was present on the left side of the Pyramid Rocks.

Figure 11. Continued.

overlap the 1939 surface at several points along both the right and left sides of Prospect Canyon. Deposits on the left side of Prospect Canyon are 1$2 \mathrm{~m}$ thick over an older surface, possibly tif.

Surface tig is poorly-sorted with $\mathrm{d}_{50}=180 \mathrm{~mm}$ (fig. 4a) and boulders with a b-axis diameter of 2.7 $\mathrm{m}$ (Appendix 4). Sixty-two percent of the clasts are basalt (fig. 5), the highest amount of basalt of any of the debris flows from Prospect Canyon. The 1939 deposit consists of at least two beds of debris-flow strata separated by tributary streamflow deposits (fig. 9). The stratigraphy represents several pulses of debris flow during a single runoff event, which is consistent with observations elsewhere in Grand Canyon (Webb and others, 1989).

On the upstream surface on channel right, boulders are deposited around mature catclaw trees, and most long-lived perennial shrubs are present downstream of boulder piles. The plants appear to have been present when the 1939 debris flow occurred, suggesting that the 1939 deposit is relatively thin. Boulders on the surface show slight weathering with prominent percussion marks. Desert plants have colonized the surfaces; sweet bebbia (Bebbia juncea), a short-lived species, contributes 10.1 percent cover and 5 other shortlived species contribute significant cover (Bowers 
and others, 1996). The edges of this surface were eroded during debris flows in 1955, 1963, and 1966.

tih

Deposits from the 1955 debris flow are preserved as eroded remnants that form small surfaces along the right and left sides of Prospect Canyon. The deposits appear superelevated along the left side of Prospect Canyon at cross section A A' (Plate I) and lap onto surface tig (fig. 6). The deposits consist of poorly-sorted sediments approximately 1-2 $\mathrm{m}$ thick inset against, and in some cases, on top of the surface tig (fig. 10). Much of the surface, which had an area of $800 \mathrm{~m}^{2}$ when we mapped it in 1993, is covered with sand and gravel that appears to have been deposited during the recessional flow of 1955. Desert vegetation on surface tih consists of short-lived species such as poreweed (Porophyllum gracile) and occasional catclaw (Acacia greggii). Much of surface tih was eroded during the 1995 debris flow.

tii

Deposits of the 1963 and 1966 debris flows were not differentiated on the Prospect Canyon debris fan. The undifferentiated deposits form a surface tii that has relatively fine-grained particlesize distribution, with $\mathrm{d}_{50}=64 \mathrm{~mm}$ (fig. 4a). This surface has poorly-sorted, subangular to rounded clasts that are 39 percent basalt and 43 percent Redwall Limestone (fig. 5). Desert plants consisting of long-leaf brickellbush (Brickellia longifolia) and other short-lived species colonized these small surfaces, which had an area of $385 \mathrm{~m}^{2}$ when we mapped them in 1993. Surface tii was almost totally removed during the 1995 debris flow.

\section{tij}

The 1995 debris flow deposited a debris fan in the Colorado River with an area of 0.56 ha. The 1995 debris flow did not create a distinct surface on the Prospect Canyon debris fan and for that reason is not included on Plate I. Most deposition was in or adjacent to the channel of the Colorado River (fig. 11a), and the large volume of recessional streamflow eroded most of the deposits left after the initial debris-flow pulse. In addition, most of the deposits of surfaces tih and tii were removed, and the edge of surface tig was eroded in places by $1 \mathrm{~m}$. The aggraded debris fan (Plate I) had four distinct areas of deposition and erosion that represent the different phases of runoff. The first pulse of sediment is beneath the main body of the debris fan; its sedimentology and volume are unknown. After this initial phase, a pulse of relatively fine-grained $\left(\mathrm{d}_{50}=50 \mathrm{~mm}\right)$ debris flow pushed out deposits on the downstream side of the debris fan (fig. 4b). The second, or main pulse of debris flow pushed directly towards the center of Lava Falls Rapid. These sediments, with $\mathrm{d}_{50}=350 \mathrm{~mm}$ (test pit, fig. 4b) and boulders up to $1.6 \mathrm{~m}$ in b-axis diameter, composed most of the aggraded debris fan. Particles in the main pulse were 50 percent basalt and 21 percent Redwall Limestone (fig. 5). The recessional pulse of debris flow was relatively fine-grained $\left(\mathrm{d}_{50}\right.$ $=40 \mathrm{~mm}$; fig. $4 \mathrm{~b}$ ). The recessional streamflowdeposited gravels and well-sorted sand $\left(\mathrm{d}_{50}=10\right.$ $\mathrm{mm}$; fig. $4 \mathrm{~b}$ ) in the channel and on the debris fan.

\section{Colluvium and Steep Slopes}

tc

Colluvium and steep slopes compose 1.12 ha of the Prospect Canyon debris fan. Unconsolidated talus displaced from nearly vertical exposures of surfaces tfa and tfc (fig. 6) forms steep slopes within the incised channel of the Prospect Canyon debris fan and along the distal edge of tfa and tfc along the Colorado River. The deposits consists of relatively well-sorted boulders, which are mostly basalt clasts that have fallen from near-vertical exposures. This deposit partially covers older, inset deposits along the right side of Prospect Canyon; in particular, surface tic has many boulders up to 5-6 $m$ in diameter on its top that are part of surface tc.

\section{Reworked Debris-Flow Deposits}


rwr

This surface is mostly boulders that are the largest clasts transported by Prospect Canyon debris flows. These boulders were deposited in or adjacent to the Colorado River and have not been removed by subsequent river floods. Between 1939 and 1995, these floods had discharges up to 3,540 $\mathrm{m}^{3} / \mathrm{s}$. This deposit has an area of 0.74 ha above the $140 \mathrm{~m}^{3} / \mathrm{s}$ stage of the Colorado River along the edge of the debris fan. The boulders are 90 percent basalt, have $\mathrm{d}_{50}=512 \mathrm{~mm}$, and b-axis diameters up to $3.0 \mathrm{~m}$ (Appendix 4). Pockets of river sand are among the boulders. The above-water area of surface rwr at the rapid was covered by the 1995 debris flow, except for some isolated boulders at the downstream end of the rapid that are in the river but not submerged at a discharge of $280 \mathrm{~m}^{3} / \mathrm{s}$.

\section{rwc}

Debris-flow deposits in the channel of Prospect Canyon are periodically reworked by tributary floods. Surface rwc has an area of 0.9 ha, and the underlying deposit consists of poorly-sorted sediment ranging from sand to extremely large boulders. Some of the boulders on surface rwc have $\mathrm{b}$-axis diameters of $7 \mathrm{~m}$ (Appendix 4). Boulders larger than $3 \mathrm{~m}$ in diameter either remained stationary or were rotated during the 1995 debris flow. In places, small flood deposits of well-sorted fine sand are present on the downstream side of obstructions such as large boulders; deposition of these flood deposits occurred during the 1993 flood and during recessional flow following the 1995 debris flow.

\section{rwfd}

Reworked debris-flow and streamflow deposits are present in internal drainage channels that dissect both debris fan-forming and inset deposits. The area of this surface is 0.32 ha (Plate I). These channel deposits are associated with infrequent runoff generated within the Prospect Canyon debris fan. Most of the deposit underlying this surface is sand and gravel, but boulders are also present. Some of these channels could have developed during dewatering of the main debris-flow deposits and (or) recessional flow after a debris flow.

\section{HISTORICAL CHANGE IN LAVA FALLS RAPID}

\section{Navigation of Lava Falls Rapid in 1994}

Traditionally, Lava Falls Rapid is scouted from the left for discharges greater than about $700 \mathrm{~m}^{3} / \mathrm{s}$ and from the right for lower-water runs. On the left side, the rapid is viewed from a point on surface tfa called the Left Scout Point or on the debris fan (fig. 11b). On the right side, the Scout Rock commands a full view of the rapid. The landmarks of Lava Falls Rapid all have names that are familiar to modern river guides. The most prominent features of the rapid are the Ledge Hole, the V Wave, the Big Wave, and the Black Rock (fig. 11b).

Hydraulic features in bedrock rivers have been classified by several researchers. Leopold (1969) described 4 types of waves according to water depth, cross section changes, and obstacles on the bed. Kieffer (1985) described large waves as hydraulic jumps, or energy conversions from supercritical to subcritical flow. Kieffer (1987) established a lexicon for hydraulic features that we use to describe Lava Falls Rapid.

The Ledge Hole is in a class by itself as a navigational hazard. The drop into the Ledge Hole - the highest vertical fall in the rapid - is only about $1.2 \mathrm{~m}$. At typical water levels, it spans a quarter of the entrance to the rapid, and water appears to pour over a fall into a recirculating hole. The linear shape of the Ledge Hole has led to speculation that a ledge or basalt dike underlies the hydraulic feature (Fradkin, 1984). At very low discharge (less than $100 \mathrm{~m}^{3} / \mathrm{s}$ ), three large boulders forming the Ledge Hole are exposed. At flood stage, the Ledge Hole becomes a massive wave.

Before the 1995 debris flow, three runs were possible, the Left Run, a run on the right side of the Ledge Hole called the Slot Run, and the Right Run (fig. 11b). Above about $600 \mathrm{~m}^{3} / \mathrm{s}$, the Left Run opens adjacent to the left side of the Ledge Hole. At lower discharges, boulders - particularly the Domer Rock - make the left side hazardous. At intermediate water levels $\left(300-600 \mathrm{~m}^{3} / \mathrm{s}\right)$, the Slot Run is an option that requires a very precise entry. In the era of dam regulation, flows are generally 


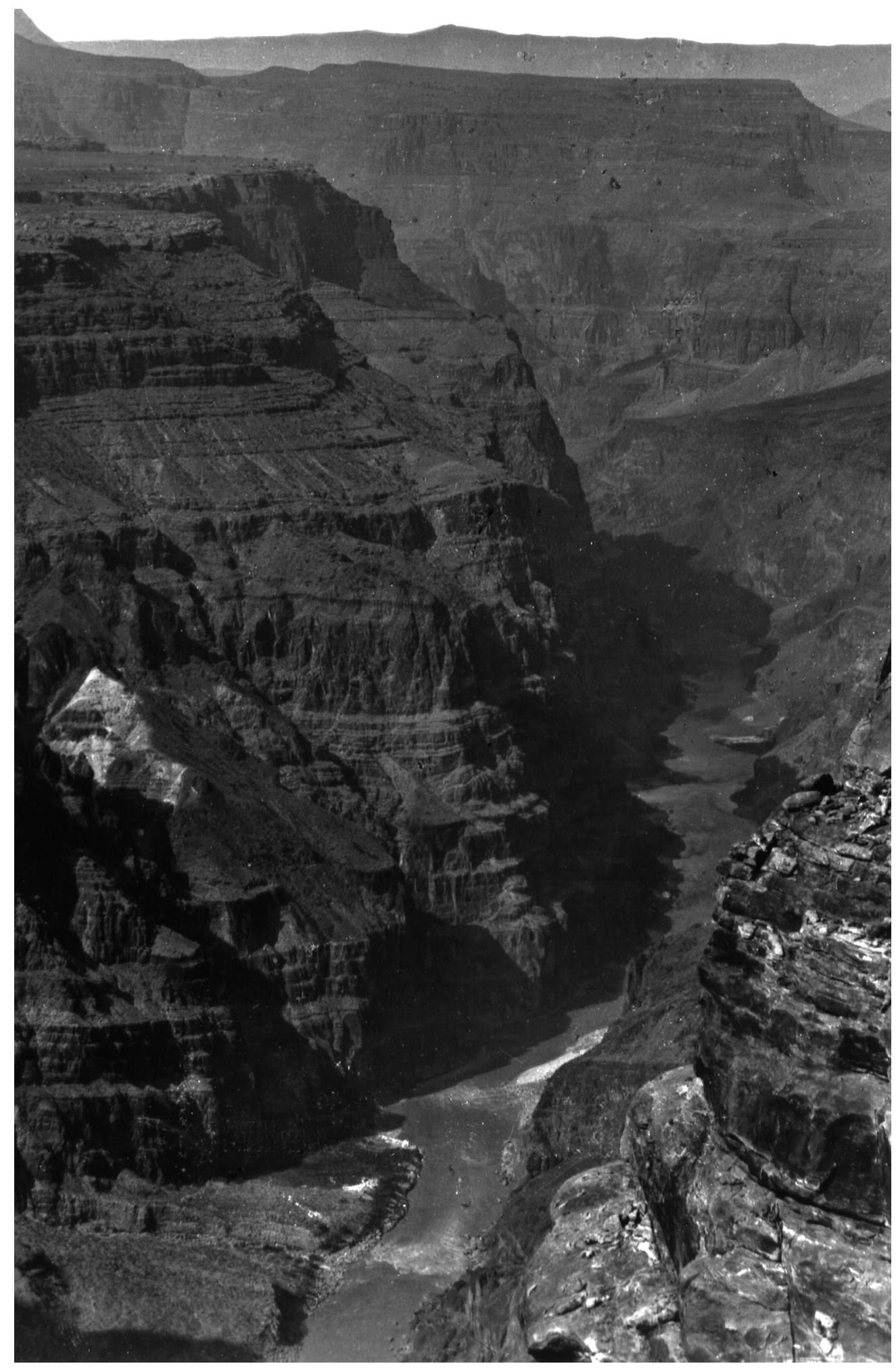

Figure 12. Downstream view of Prospect Canyon and Lava Falls Rapid from Toroweap Overlook (Stake 967). A. (April 16, 1872; J.K. Hillers, courtesy of the National Archives). Lava Falls Rapid as viewed by the Powell Expedition was completely different from the rapid now familiar to thousands of whitewater enthusiasts. Using photogrammetric rectification, we found that the rapid began $85 \mathrm{~m}$ farther downstream on the left side, and the head of the rapid formed a line perpendicular to flow. A prominent tongue of water entered the left side of the rapid, and its tail waves at the bottom flowed directly downstream. At the discharge shown (approximately $300 \mathrm{~m}^{3} / \mathrm{s}$ ), the area of the exposed debris fan is about 0.2 ha. 


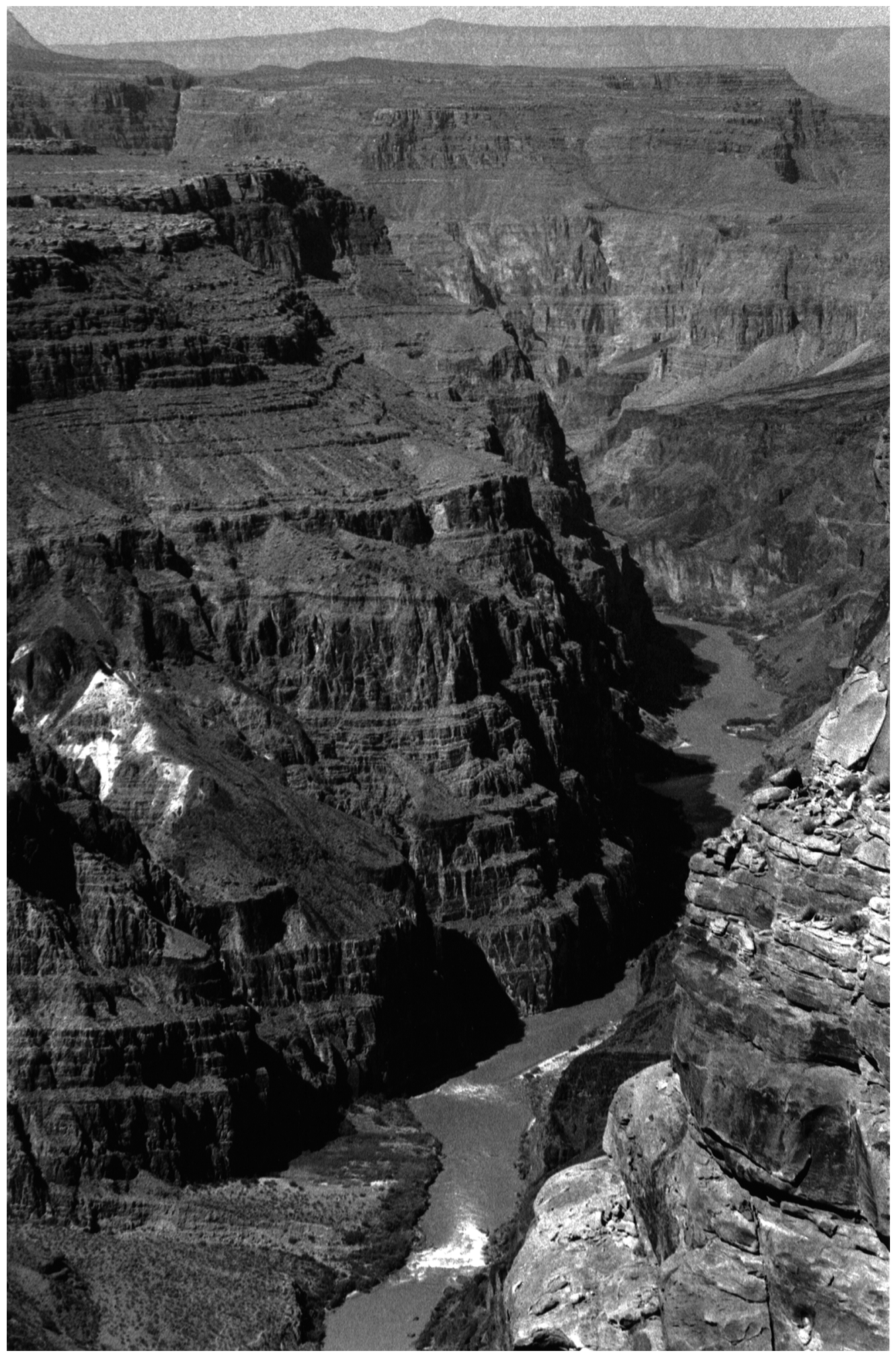

B. (June 10, 1979; R.M. Turner). After a series of debris flows from 1939 through 1966, Lava Falls Rapid changed substantially. At a discharge of about $340 \mathrm{~m}^{3} / \mathrm{s}$ in 1979, the head of the rapid slanted downstream to the right side, and the main tongue was on the right side. The tail waves were much farther downstream and curved towards the left. Two distinct levees in the mouth of Prospect Canyon were deposited between 1872 and 1966; the largest levee was deposited by the 1939 debris flow, and the smaller, inset levee is remnant channel fill from the 1963 and 1966 debris flows. The debris-flow deposits in the mouth of Prospect Canyon are overgrown with dense riparian vegetation.

Figure 12. Continued.

30 The Great Cataract 


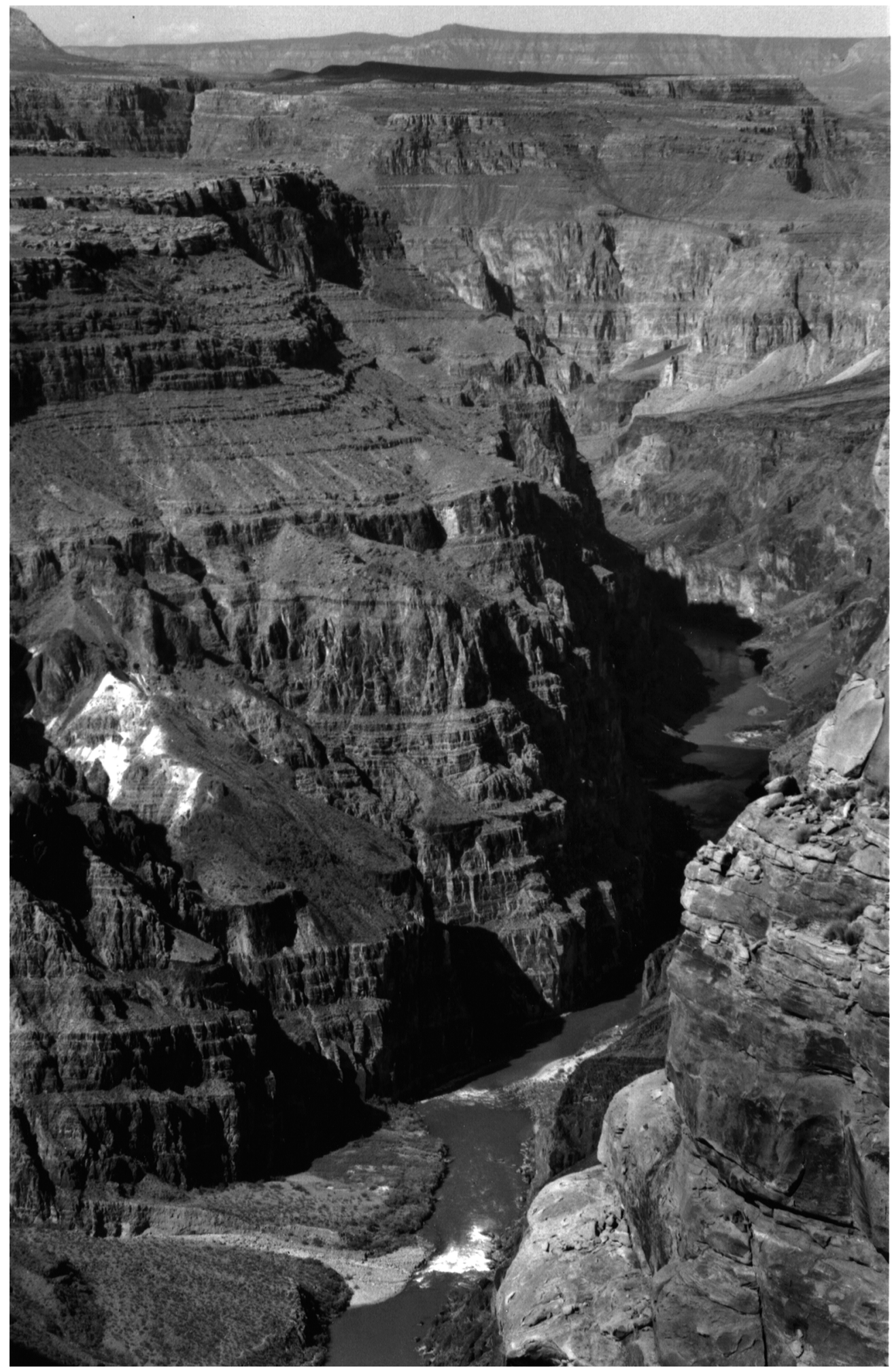

C. (May 16, 1995; R.M. Turner). The debris flow of March 6, 1995, initially constricted the Colorado River by 62 percent, but reworking quickly widened the river and reduced the constriction, as shown here, to about 50 percent. The constriction increased the drop through Lava Falls Rapid, accentuating its hydraulics, but some formerly prominent waves, such as the Big Wave, were not present. The 1963 and 1966 debris-flow deposits were completely eroded from the margins of Prospect Canyon. At this discharge of about $260 \mathrm{~m}^{3} / \mathrm{s}$, the exposed area of the new debris fan is 0.62 ha.

Figure 12. Continued 


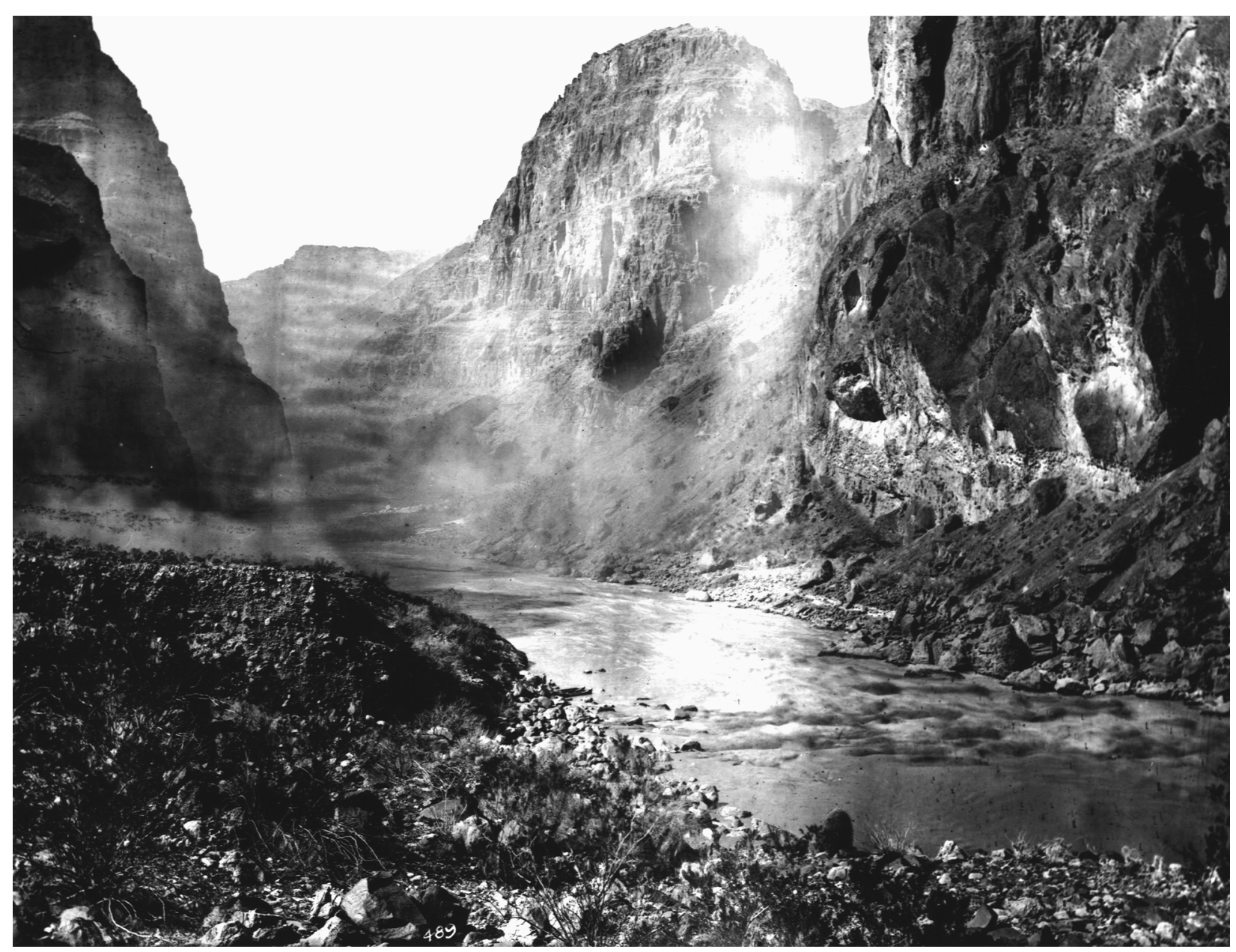

Figure 13. Downstream view of Lava Falls Rapid from the high surface on the left side (Stake 1510b). The channel of Prospect Canyon, which enters the Colorado River from the left, appears in the center of the view. A. (February 27, 1890; R.B. Stanton, courtesy of the National Archives). The last vestiges of smoke from a large fire set by the Stanton expedition are shown at left center. The left side of the rapid has flat, relatively slow-moving water adjacent to the mouth of Prospect Canyon. The Deflector Rock is visible on the right side approximately $15 \mathrm{~m}$ upstream from the Black Rock. Tail waves from the rapid are deflected away from the Black Rock and the main flow is down the center of the rapid. The water level is $280-400 \mathrm{~m}^{3} / \mathrm{s}$.

low enough that the Ledge Hole can easily be avoided on the Right Run.

The Right Run at Lava Falls (fig. 11b) is used over most of the range of dam releases but it is by no means easy. The run consists of entering right near the Entrance Rock, running a powerful lateral wave, and aligning the boat for the $\mathrm{V}$ Wave, a nearly symmetrical pair of reflex lateral waves that meet in the middle of the Right Run. The V Wave is generated from large boulders on the right shore and a large boulder in the rapid known as the Meteor Rock, which is submerged at most discharges and constricts the right side of the channel. The pair of lateral waves that form the $\mathrm{V}$ Wave tend to alternatively fold one over the other, adding an element of suspense as to which wave will crash on a boat first.

Once through the V Wave, boats pass through waves that are some of the biggest in Grand Canyon. On the bottom right side of the rapid (fig. 11b), the Black Rock, a large basalt boulder, diverts current to the left; just upstream, a large wave appropriately called the Big Wave typically crashes upstream. Depending on the surges at this point, a 


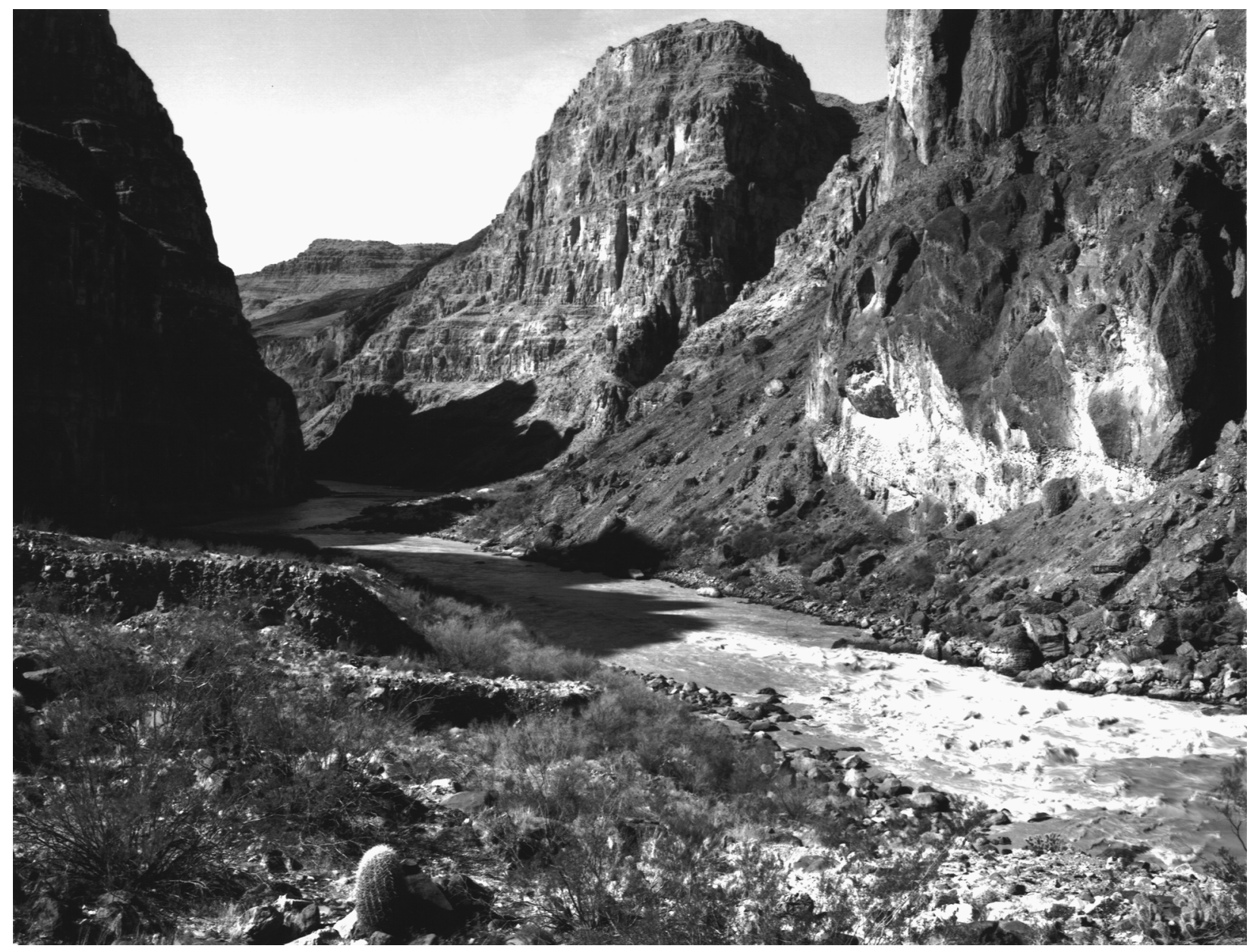

B. (February 11, 1990; R.M. Turner). Debris flows from Prospect Canyon changed the rapid substantially in the 20th century. The rapid now begins farther upstream. The 1939 debris flow deposited the prominent low surface at left center. Deposition during the 1939 event forced flow through the rapid to the right; the Deflector Rock moved downstream and was submerged at most water levels. The Black Rock deflects typical dam releases to the left. Debris flows in 1954, 1955, 1963, and 1966 deposited sediment along the left side of the rapid, changing a relatively quiescent area to whitewater choked with boulders.

Figure 13. Continued.

boat can run safely, be flipped by the Big Wave, or be rafted onto the Black Rock. Downstream, the tailwaves of the rapid dissipate into a pool.

Lower Lava Rapid is the next obstacle downstream from Lava Falls (fig. 2). This secondary rapid, formed from cobble and boulder outwash from Prospect Canyon debris fan, consists of a tight river bend against a vertical limestone cliff. Although Lower Lava is not a noteworthy rapid by itself, it forms a distinct hazard to swimmers and overturned boats after an upset in Lava Falls.

\section{The Wide, Stable Rapid (1872-1939)}

When analyzing early accounts of Lava Falls Rapid, the level of the expedition's whitewater expertise, the size and type of boats used, the context of the trip, and the discharge in the river are important factors to consider. Advances in technique and equipment have revolutionized river 


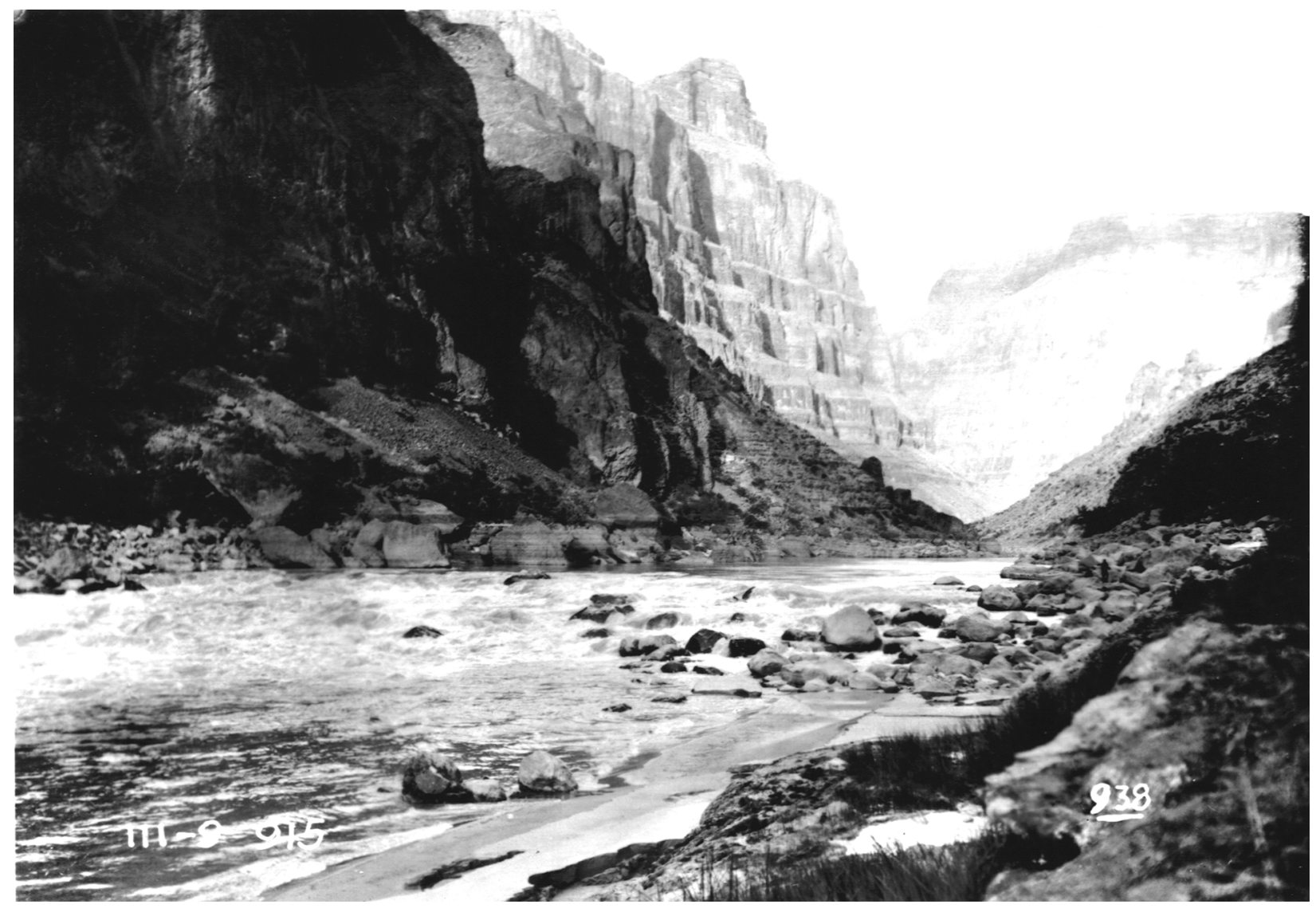

Figure 14. Upstream view of Lava Falls Rapid from the left side (November 10, 1909; R. Cogswell, courtesy of the Bancroft Library, University of California at Berkeley). Boulders that appear on the debris fan and in the river in this view also appear in views taken by Hillers (1872) and Kolb (1912). Photographs taken in 1923 and 1927 show the same boulders, which demonstrates the stability of the rapid in floods of at least $6,200 \mathrm{~m}^{3} / \mathrm{s}$.

running, and impressions of the severity of rapids such as Lava Falls have changed greatly during the last three decades. Three rapids - Lava Falls, Separation (mile 239.5) and Lava Cliff (mile 246.0) - were serious challenges to early navigation in western Grand Canyon; explorers typically compared the severity of these rapids (Marston, 1976). When Hoover Dam was completed in 1935 on the lower Colorado River, the rising waters of Lake Mead inundated Separation and Lava Cliff rapids.

John Wesley Powell, the first explorer of the Colorado River in 1869, was impressed with the lava flows over the rim and the severity of Lava Falls Rapid. Powell considered the rapid to be an artifact of the basalt dams that spanned the canyon. In his diary, he wrote

Come to ... lava falls [the lava flows]. These falls must have been very great at one time. Lava comes down to high water mark - may be lower - and $1500 \mathrm{ft}$ [500 m] high on either side. The canon was filled... The falls [Lava Falls Rapid] now are among boulders some distance below the ancient fall (Cooley, 1988, p. 173).

Powell's crew thought Lava Falls Rapid was the closest thing to a waterfall that they had seen; they portaged it on the left. Powell later commented extensively on the difficulties his expedition encountered downstream at Separation Rapid (Powell, 1875), which led to the erroneous impression that Separation Rapid was a more formidable obstacle than Lava Falls (Marston, 1976). Powell's photographers travelled overland to make the first photographs of Lava Falls in April 1872 (figs. 12a and 15a; Fowler, 1972; Stephens and Shoemaker, 1987).

In the winter of 1889-90, Robert Brewster Stanton led the second complete expedition through Grand Canyon (Smith and Crampton, 1987). The 
goal of his expedition was to determine the feasibility of a water-level railroad from Grand Junction, Colorado, to Needles, California. He documented the route with systematic photography (Webb, 1996). On the afternoon of February 26, 1890 , Stanton's expedition arrived "at the head of the great cataract formed by the lava dike" (Smith and Crampton, 1987, p. 225). The following day, the crew portaged the boats along the left side while Stanton photographed the rapid (fig. 13a). In his diary, Stanton remarked that Lava Cliff Rapid, farther downstream and now inundated by Lake Mead, was the most difficult whitewater he saw in Grand Canyon, as well as the most difficult place for constructing a railroad (Smith and Crampton, 1987).

Following Stanton in 1896, George Flavell, a skilled and confident outdoorsman, became the first person to run all three of the big rapids in western Grand Canyon (Carmony and Brown, 1987). Regarding his historic run through Lava Falls Rapid, Flavell briefly wrote: "A bad rapid [Lava Falls] was run which put about eight inches of water in the boat. It was pretty fresh, but we had to stand it" (Carmony and Brown, 1987, p. 69). Although Lava Falls was not very challenging, Flavell was greatly impressed by Lava Cliff Rapid, which he stated "was as dangerous as any on the whole river" (Carmony and Brown, 1987, p. 70).

Two early 20th century expeditions yielded important photographs and notes on Lava Falls. In 1909, Julius Stone led a trip through Grand Canyon (Stone, 1932) with a photographer, Raymond Cogswell, who took the best set of photographs of the rapid made before the 1950s (e.g., fig. 14). According to Cogswell's diary,

It [Lava Falls Rapid] is impossible to run with safety, a sheer cascade of 8 feet $[2.6 \mathrm{~m}]$. One might scratch thru [sic]. We land stuff at head and portage down about 150 yards [146 $\mathrm{m}$ ] to creek. Then one boat is lined and portaged down. Heavy work ...The roar of the rapids and the menace of it, the spice of danger, and the thought of the comfort of a home fireside. We are jolly around the camp fire and enjoy it. This rapid full of rocks (R.A. Cogswell, unpublished diary, courtesy of the Huntington Library).
Cogswell's photographs support his description of the length of the rapid, its fall, and the extraordinary number of exposed rocks that made a run implausible.

Expeditions continued to photograph the rapid. The Kolb brothers, famed photographers of Grand Canyon, ran the river in the fall and winter of 19111912 (Kolb, 1914); they photographed Lava Falls after a portage in January 1912 (fig. 16a). Other river runners photographed the rapid in 1927 and 1934 (fig. 17).

In 1923, the U.S. Geological Survey mapped potential dam sites along the Grand Canyon (Birdseye, 1924; Freeman, 1924). During the expedition, the water-surface fall of the Colorado River was measured and "adjusted" in an undescribed manner to a uniform discharge of 280 $\mathrm{m}^{3} / \mathrm{s}$. Upon arrival at Lava Falls, they photographed the rapid at a discharge of $260 \mathrm{~m}^{3} / \mathrm{s}$ but the surveying crew did not measure its fall. In the middle of the night, a flood of $3,200 \mathrm{~m}^{3} / \mathrm{s}$ caused the river to rise $6.4 \mathrm{~m}$ in $24 \mathrm{hrs}$ (Claude H. Birdseye, unpublished diary, 1923; Freeman, 1924), which delayed the surveying for several days. The expedition continued downstream on a discharge of about $1,000 \mathrm{~m}^{3} / \mathrm{s}$, and the surveyed fall of $12 \mathrm{~m}$ was measured over a 2.4-km distance that includes Lava Falls Rapid, Lower Lava Rapid, and several riffles downstream (Birdseye, 1924). The surveying problem generated by the 1923 flood fueled the current misconception of a 12-m fall through Lava Falls (Webb, 1996).

Despite the increasing numbers of river runners who faced the rapid, few actually ran it. In 1927, Clyde Eddy claimed the rapid had a sheer drop of "20 feet [6.1 m] or more" (Eddy, 1929). In December 1928, Jack Harbin, who was searching for two missing river runners, made the second successful run of the rapid (Cook, 1987, p. 109). According to an interview conducted by Otis "Dock" Marston in March 1948, Harbin and his passenger related troubles caused by the rocky rapid. As his passenger watched from the right shore, Harbin attempted to enter the rapid on the right side but became snagged on a shallowly submerged rock. Eventually, his boat washed off of the rock but a wave in the rapid broke a board free 


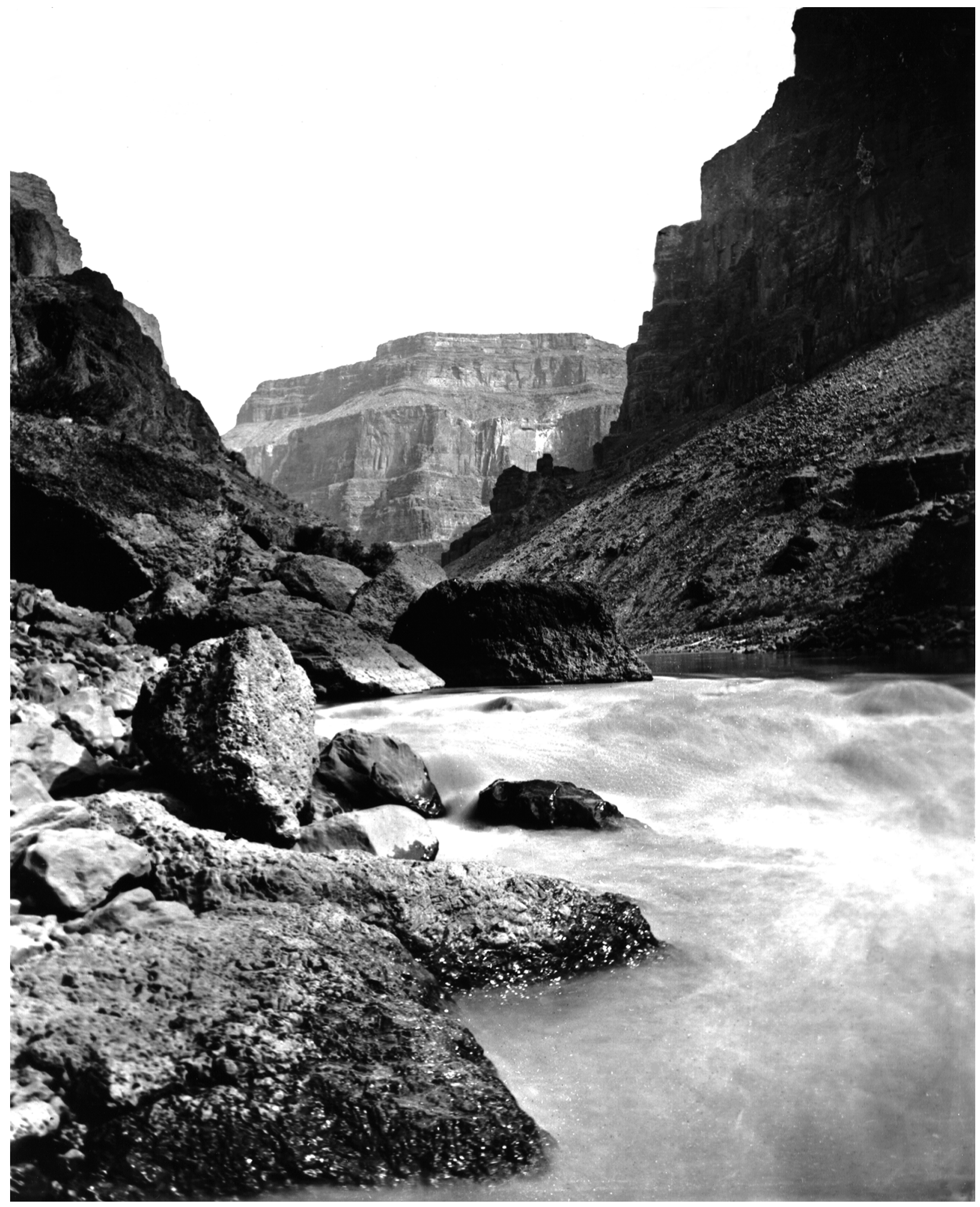

Figure 15. Upstream views of the head of Lava Falls Rapid from the right side (Stakes 2598 and 2662). A. (April 19, 1872; J. K. Hillers, courtesy of the National Archives). At a discharge of about $280 \mathrm{~m}^{3} / \mathrm{s}$, the Entrance Rock appears in the center; a very small eddy formed behind this rock in 1872 . Many rocks and small pourovers are visible in the center of the photograph. This photograph is also shown in Graf (1979). 


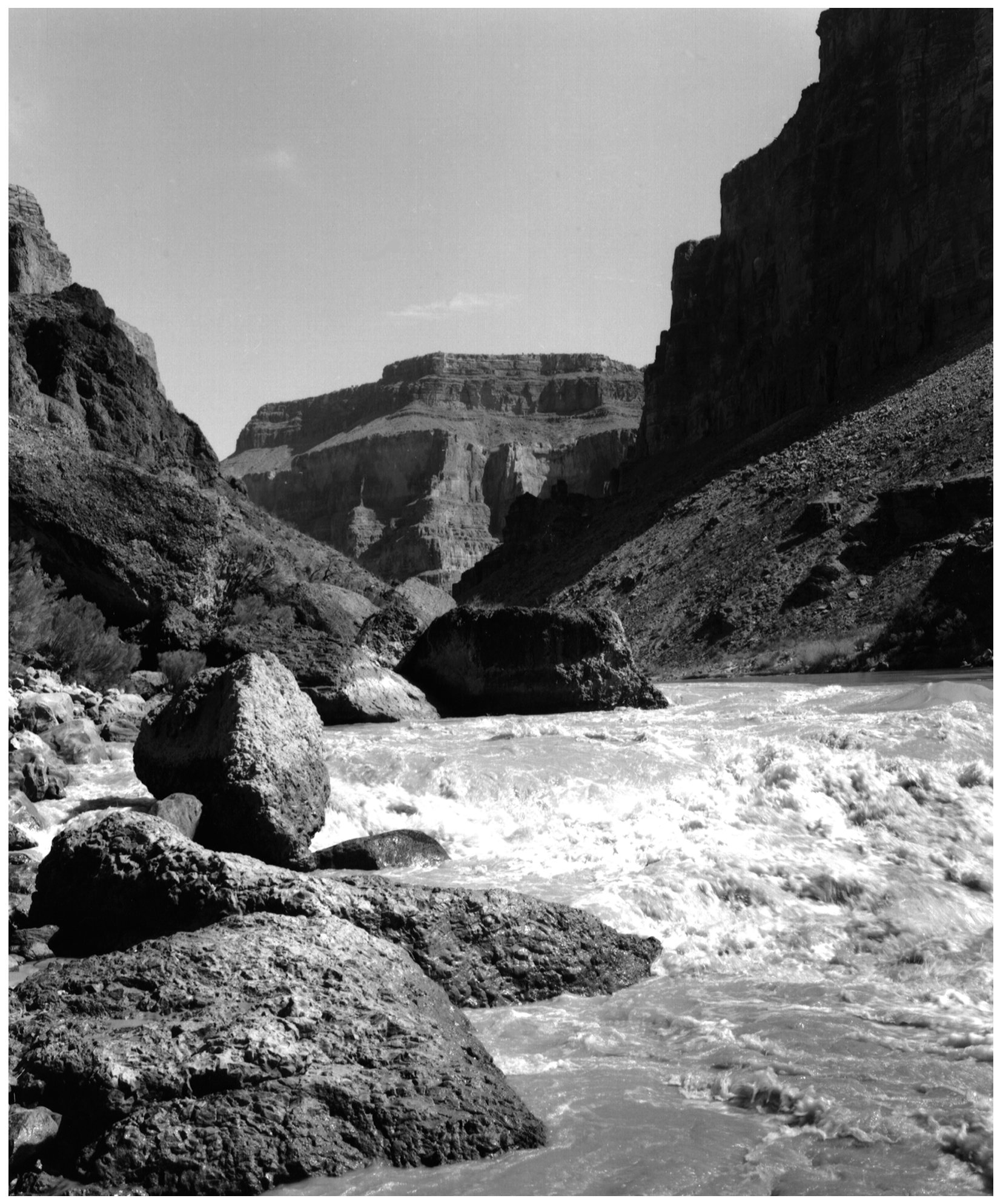

B. (March 8, 1993; L. Hymans). Even though flow in the Colorado River $\left(310-340 \mathrm{~m}^{3} / \mathrm{s}\right)$ is only slightly higher, the stage appears much higher than in 1890. A sizeable eddy forms behind the Entrance Rock. Now, rocks or pourovers are not visible above $140 \mathrm{~m}^{3} / \mathrm{s}$. Also, water flows around the right side of the large basalt boulder in the center of the view.

Figure 15. Continued. 


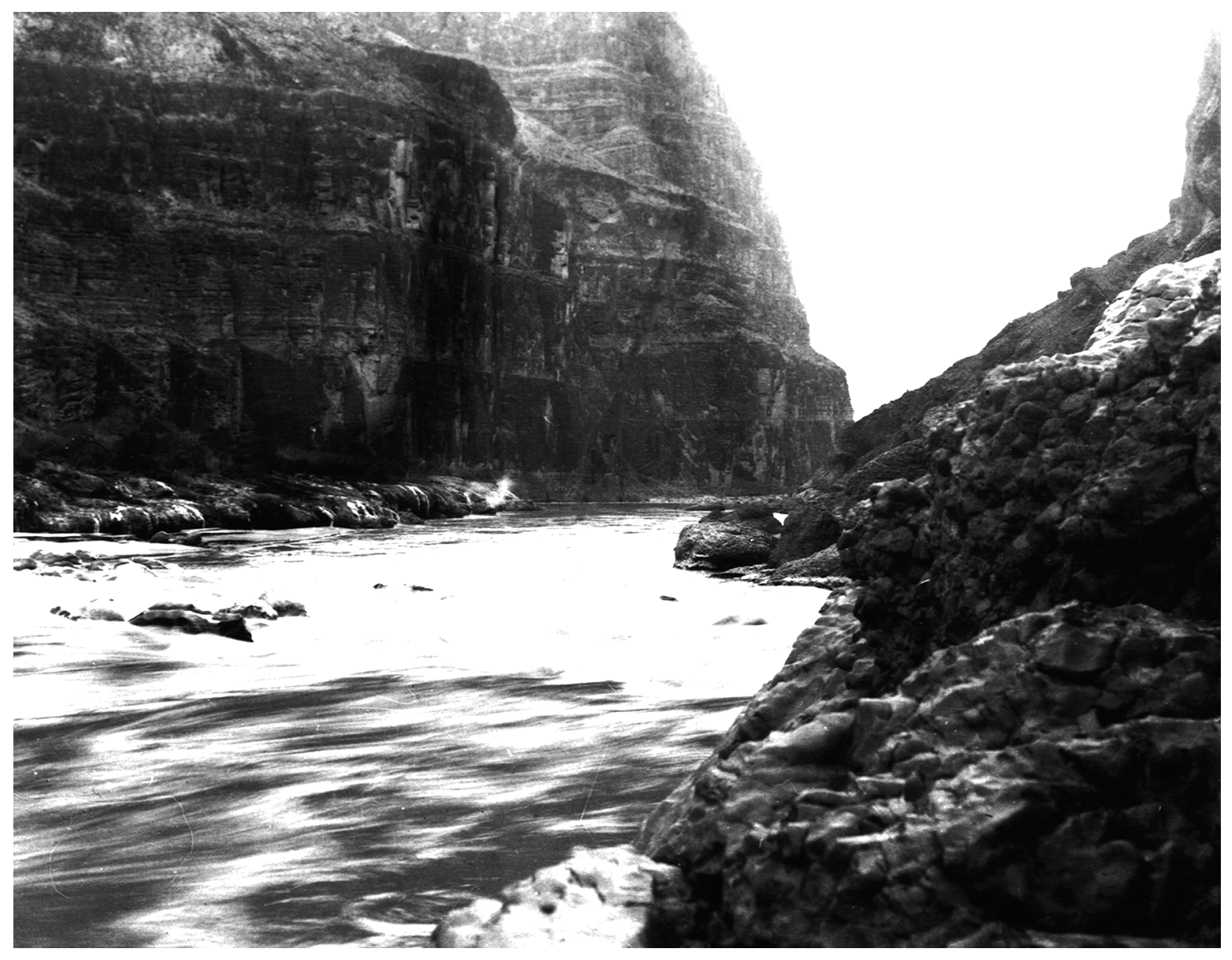

Figure 16. Downstream view of the right side of Lava Falls Rapid (Stake 2599). A. (January 1, 1912; E. Kolb, courtesy of Northern Arizona University Special Collections). The discharge is $28-85 \mathrm{~m}^{3} / \mathrm{s}$, and the Deflector Rock, near the right shore, obstructs the view of the Black Rock. The sand bar at the left and rocks that are exposed in the center of the rapid were typically covered at discharges greater than $280 \mathrm{~m}^{3} / \mathrm{s}$. Several expeditions, including the Kolb brothers, camped on the sand bar after portaging the rapid 


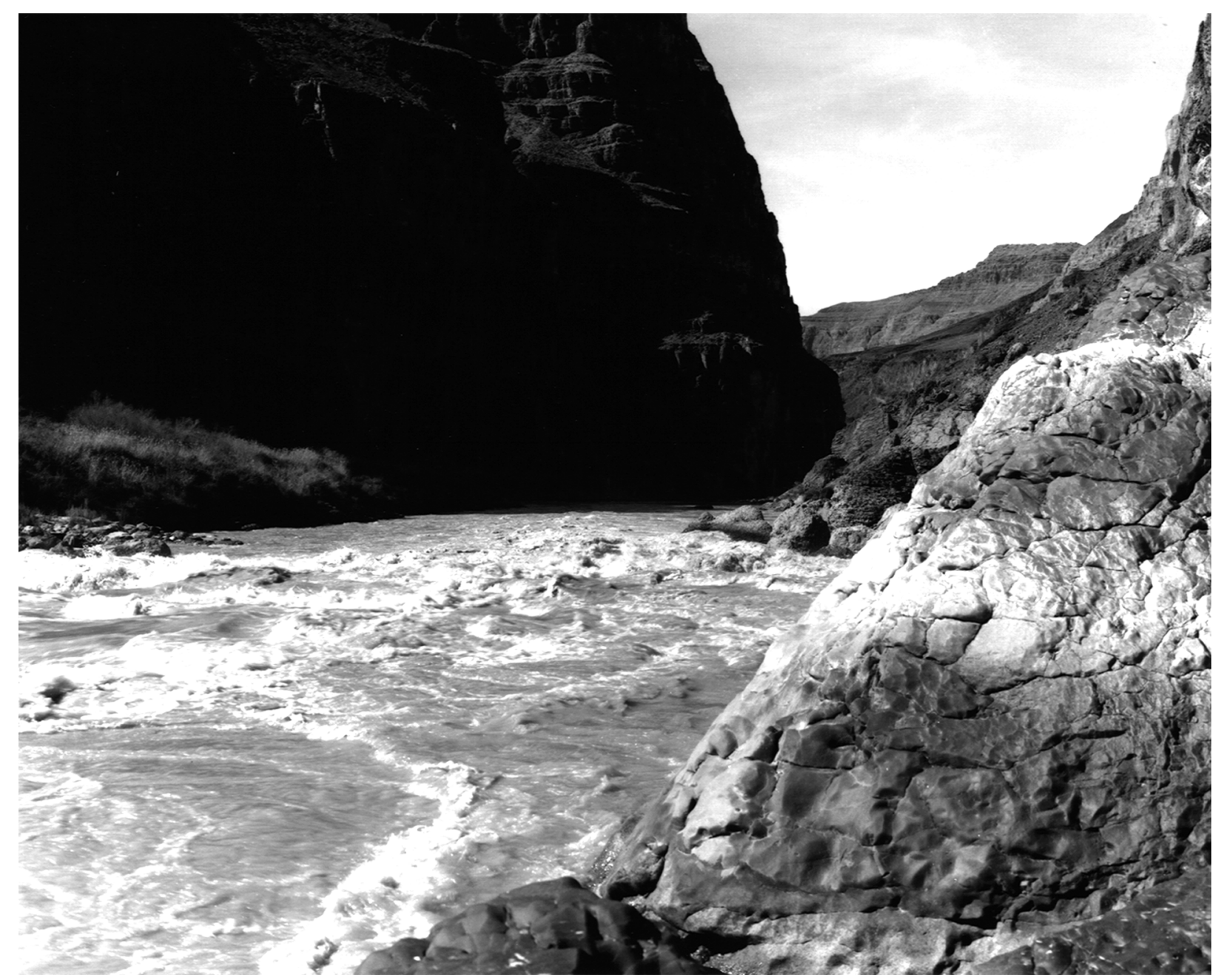

B. (March 9, 1993; L. Hymans). At a discharge of $310 \mathrm{~m}^{3} / \mathrm{s}$, no rocks are exposed in the center of the rapid. The Deflector Rock was rotated and moved downstream toward the center of the channel and usually is submerged. The Big Wave, to the left of the Black Rock, forms from flow over the submerged boulder. A large part of the basalt boulder in the right foreground has been eroded.

Figure 16. Continued. 


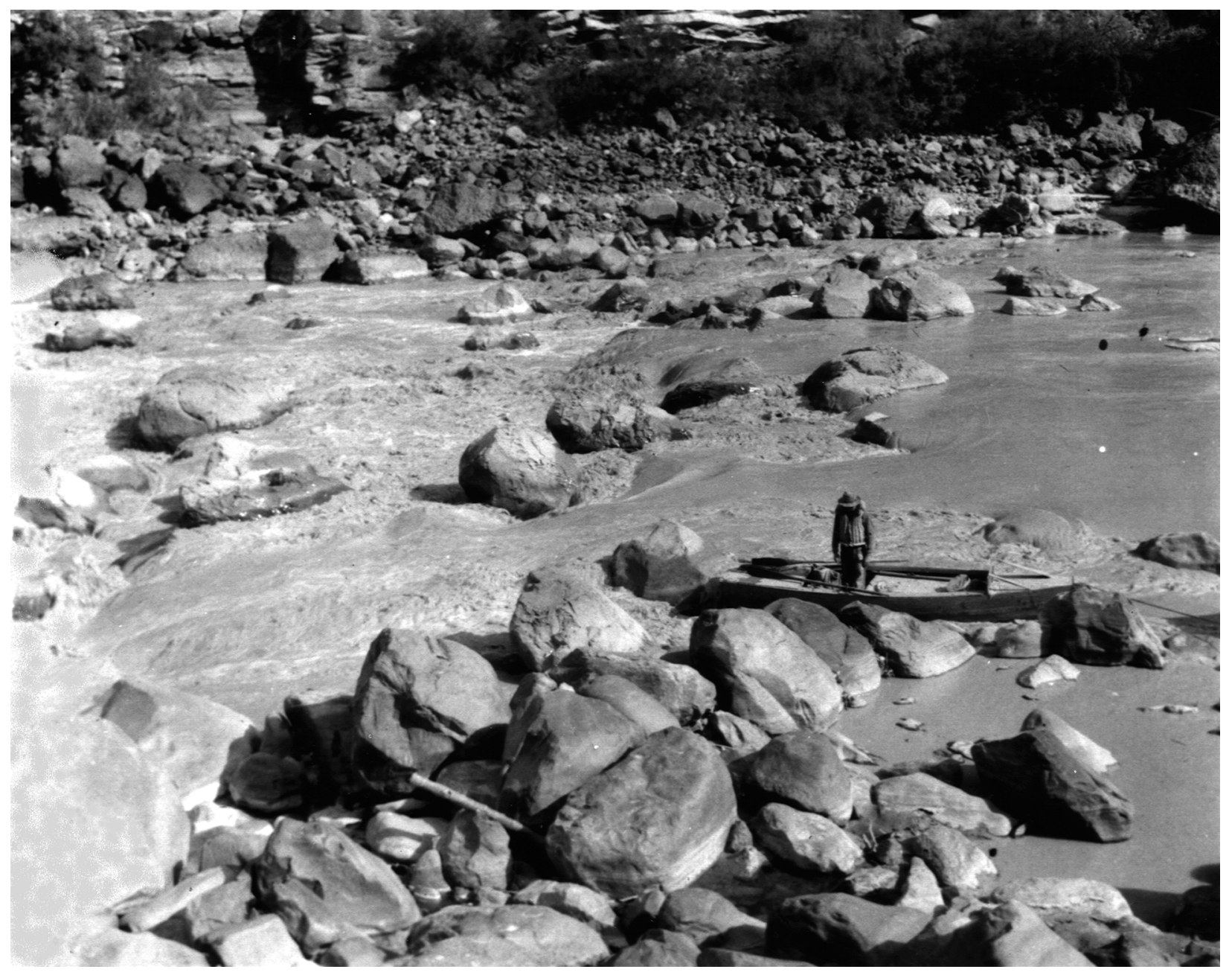

Figure 17. View of Lava Falls Rapid from the left side (July 31, 1934; B. Fahrni, courtesy of the Utah State Historical Society). The crew of the 1934 Frazier-Hatch expedition are lining boats to the head of the rapid to begin a portage. The discharge was $60 \mathrm{~m}^{3} / \mathrm{s}$, one of the lowest summer levels recorded in the 20th century, and the boulders that form the rapid protrude from the water. The Pyramid Rocks are visible at the upper right of the view. Many of the boulders shown in this view were dislodged or buried by the 1939 debris flow. After 1957, the Ledge Hole formed downstream from the boulders visible in this 1934 view. 


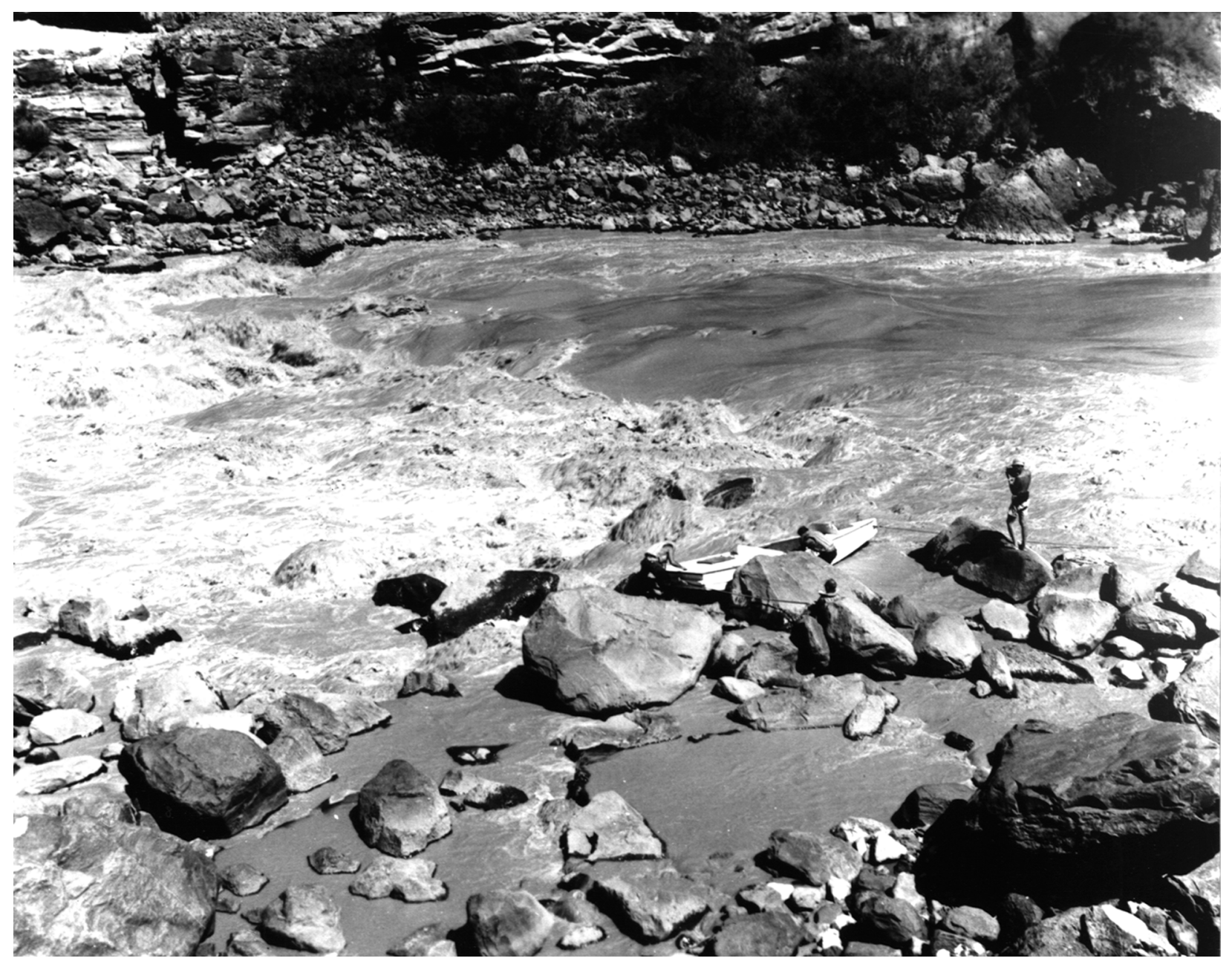

Figure 18. Views of Lava Falls Rapid from the left side (Stake 2660a). A. (July 26, 1942; N. Wilson, courtesy of the University of Utah Marriott Library). In this upstream view, the crew of the Nevills expedition is lining boats along the left side of the rapid. The 1939 debris flow completely changed the flow pattern in the rapid. The Pyramid Rocks were removed from the center of the rapid, and large holes punctuated the left side. The photographer stood on a debris fan that was 3-4 m higher than the fan in 1993; the deposits of the 1939 debris flow were subsequently reworked by Colorado River floods or Prospect Canyon debris flows. 


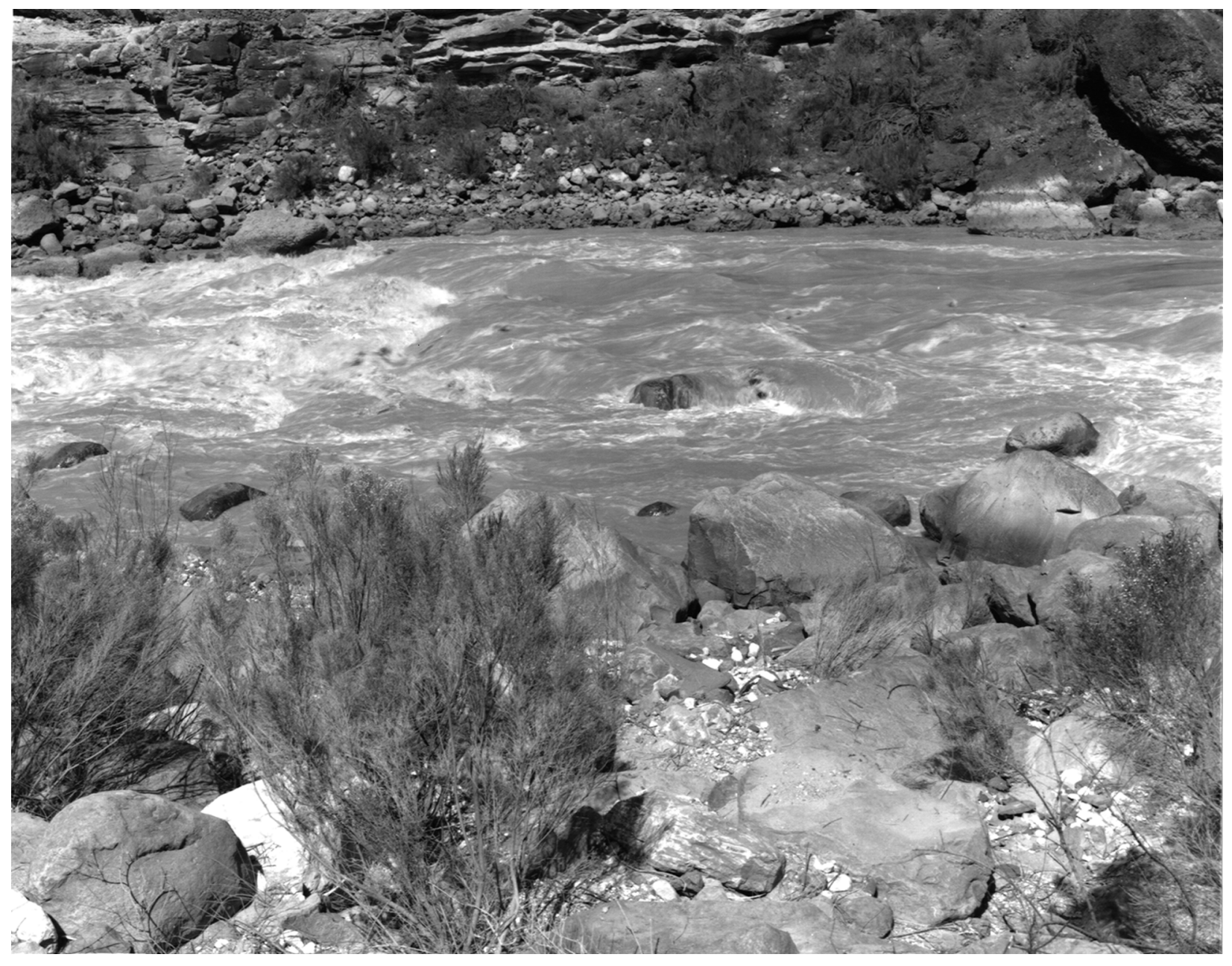

B. (March 10, 1993; S. Tharnstrom). At a discharge of 310-340 $\mathrm{m}^{3} / \mathrm{s}$, the apparent stage is about $0.5 \mathrm{~m}$ lower than in 1942. Debris flows after 1942 deposited rocks in the center of the rapid that form the Ledge Hole, which does not appear in the 1942 view. Riparian vegetation has invaded the debris fan.

Figure 18. Continued. 
from the boat, injuring Harbin's spine. The injury still caused Harbin problems in 1948.

The 1937 Carnegie - Cal Tech expedition chose to portage the rapid that geologist Robert P. Sharp described as "a short, nasty, rock rapids" (R.P. Sharp, unpublished diary entry for November 15, 1937; courtesy of Special Collections, Cline Library, Northern Arizona University). Buzz Holmstrom made the third successful run in October 1938 (Lavender, 1985). In July 1938, at a discharge of $570 \mathrm{~m}^{3} / \mathrm{s}$, Norman Nevills chose to line Lava Falls on the left, noting that a right run was possible but risky (Cook, 1987). In July 1939, Don Harris and Bert Loper rowed down the right side at $232 \mathrm{~m}^{3} / \mathrm{s}$ and "lightly touched a rock." Because Separation and Lava Cliff rapids were inundated in the mid-1930s, Loper compared Lava Falls with another rapid upstream:

\section{...although it was a BAD rapid we did not find it as bad as Hance Rapid ... Hance has a fall of 27 feet $[8.8 \mathrm{~m}]$ and Lava has 23 feet [7.5 m] fall ... in a little more than $1 / 2$ of the distance (Bert Loper, unpublished diary, courtesy of the Huntington Library).}

Only 5 boatmen are known to have rowed boats through Lava Falls Rapid before 1940. For early explorers, the decision whether to portage or run the rapid was influenced largely by water level. The total fall was variously described as 3 or $7 \mathrm{~m}$; photographs suggest the fall was closer to $3 \mathrm{~m}$. Large boulders, which typically were exposed or shallowly submerged, created serious hazards for wooden boats. At low water, no specific tongue was present; instead, a line of drops perpendicular to the channel occurred across the top of the rapid. Potential runs appear in photographs on the right and left sides, but the only documented runs were on the right. Before 1939, tail waves in the rapid appeared to follow a straight path to the bottom of the rapid at all water levels. Lava Falls Rapid at that time was short, in accord with the descriptions of "falls" and "cascade." At discharges below about $300 \mathrm{~m}^{3} / \mathrm{s}$, the rapid ended upstream from the Black Rock (fig. 11a).

Lava Falls Rapid had three significant features that stand out in the pre-1939 photographs and movies (fig. 11a). In similar views of the rapid taken from Toroweap Point in 1872 and from an aircraft in 1936, the rapid is wide and the lip of the rapid slants downstream toward the left side. At discharges less than about $500 \mathrm{~m}^{3} / \mathrm{s}$, a prominent pile of boulders at the top left of the rapid marked the beginning of the cascade. These boulders, which collectively take on the appearance of a pyramid at a distance, are referred to here as the Pyramid Rocks. The boulders are not present in any photographs taken after 1939 and are not the boulders that form the current Ledge Hole. No boulders are exposed at dam releases above 85 $\mathrm{m}^{3} / \mathrm{s}$ at the former position of the Pyramid Rocks.

Another significant feature of the pre-1939 rapid is a large basalt boulder located just upstream of the Black Rock (fig. 11a). This boulder, which is rectangular with exposed dimensions of 4 and $8 \mathrm{~m}$, can be distinguished in photographs taken from Toroweap Overlook; it was submerged above a discharge of $850 \mathrm{~m}^{3} / \mathrm{s}$. We named this boulder the Deflector Rock because it forced water away from the Black Rock and deflected the tail waves of the rapid down the center of the channel at all water levels. Flow immediately upstream from the Black Rock was relatively calm because of the presence of the Deflector Rock. Movies taken in 1938 and 1939 clearly show a mildly turbulent eddy upstream from the Black Rock that contained driftwood. Now, spectacular boat upsets occasionally occur near the former position of the now-submerged Deflector Rock.

Finally, large boulders dominated the surface of the debris fan, particularly the part that was just above water at $280 \mathrm{~m}^{3} / \mathrm{s}$. Several of these distinctive boulders, with diameters of 3-4 m, are in the same place in photographs taken in 1872 (fig. 15a), 1890 (fig. 13a), 1909 (fig. 14), 1912 (fig. 16a), and 1934 (fig. 17). In addition to the lack of change in the largest boulders between 1872 and 1909, no smaller boulders were added to the debris fan and a mature riparian thicket appears in the mouth of Prospect Canyon. An 1872 view by William Bell of the Wheeler Expedition (not shown) depicts a small channel in Prospect Canyon where a broad debrisflow conduit appeared in 1995. A similar view, taken by Maxon in 1936 (Appendix 1), shows the same conditions in Prospect Canyon as in 1872. The lack of change shown in photographs of the debris fan indicates that no debris flows occurred from 1872 through 1939. The small, inactive channel in the 1872 view suggests that no debris 
Table 4. Dates and photographic evidence for debris flows and other floods in Prospect Canyon

\begin{tabular}{|c|c|c|c|c|c|}
\hline Year & Type of event & $\begin{array}{l}\text { CONSTRAIN } \\
\text { PHOTOGRAP } \\
\text { Before event }\end{array}$ & $\begin{array}{l}\text { DATES OF } \\
\text { EVIDENCE } \\
\text { After event }\end{array}$ & $\begin{array}{c}\text { Known date } \\
\text { of event }\end{array}$ & $\begin{array}{c}\text { Probable date } \\
\text { of event }\end{array}$ \\
\hline 1939 & Debris flow & Jul 15, 1939 & Aug 17, 1940 & n.d. & Sep 6, 1939 \\
\hline 1954 & Debris flow & Jun 14, 1954 & Aug 29, 1954 & July 24,1954 & \\
\hline 1955 & Debris flow & Jul 20, 1955 & Oct 1955 & n.d. & July 24, 1955 \\
\hline 1956 & Flood & Apr 16, 1956 & Sep 29, 1956 & n.d. & Jul 31, 1956 \\
\hline 1963 & Debris flow & Aug 24, 1963 & Sep 25, 1963 & n.d. & Sep 18,1963 \\
\hline 1966 & Debris flow & Jul 1966 & Apr 30, 1967 & Dec 6, 1966 & n.d. \\
\hline 1993 & Flood & Aug 18, 1992 & Mar 9, 1993 & Feb 8, 1993 & n.d. \\
\hline 1995 & Debris flow & Mar 5, 1995 & Mar 6, 1995 & Mar 6, 1995 & n.d. \\
\hline
\end{tabular}

* Dates of debris flows known accurately from eyewitness accounts or written reports.

$\dagger$ Probable dates of debris flows are based on rainfall records (Appendix 3)

flows had occurred for a minimum of several decades before 1872 .

The wide, rocky rapid began farther downstream on the left and was characterized by relatively slow velocities before 1939. By rectifying the 1872 photograph from Toroweap Overlook (fig. 12a), we determined that the point where whitewater began was about $85 \mathrm{~m}$ downstream of the same point in 1994. Using the movie shot during the Harris-Loper trip at a discharge of $220 \mathrm{~m}^{3} / \mathrm{s}$, we estimated that the boats, which were not rowed downstream, had a velocity of about $2 \mathrm{~m} / \mathrm{s}$ through the right run. Kieffer (1988) estimated an average surface velocity of about $5 \mathrm{~m} /$ $\mathrm{s}$ for the right side in 1985.

\section{The Period of Frequent Debris Flows (1939-1966)}

The axiom that "debris flows beget debris flows" (Webb, 1996) is well illustrated by what happened in Prospect Canyon from 1939 through 1966. A major debris flow in a Grand Canyon tributary increases the probability that more will occur shortly thereafter. Debris flows commonly destabilize sediment on colluvial wedges and in channels that easily can be mobilized by later floods. Despite the fact that severe storms required for initiation are controlled by atmospheric processes beyond the canyon rim, the presence of readily mobilized sediment in the drainage basin allows for frequent debris flows. For these reasons, after a long hiatus, Prospect Canyon had a succession of debris flows that altered the shape and flow patterns of Lava Falls Rapid.

The first and largest historic debris flow in Prospect Canyon occurred between July 15, 1939, and August 17, 1940, as documented by a 1939 movie and 1940 photographs (Appendix 1; table 4). A 1941 photograph by McKee (Appendix 1), from a similar vantage point as Bell's 1872 view of Prospect Canyon, shows a widened channel full of boulders at the head of the debris fan. The 1939 debris flow changed most of the features of the Lava Falls Rapid. The Pyramid and Deflector rocks were moved from their previous positions, the pattern of flow through the rapid was significantly altered, the debris fan was covered with at least $4 \mathrm{~m}$ of poorly sorted sediment, and surface tig was deposited on the left side of Prospect Canyon (figs. 6 , 13). Using the historical photographs, we identified the ten largest boulders that were deposited by the 1939 debris flow; these boulders were not subsequently removed from the debris fan. The boulders, all of which are basalt, weighed between 3 and $22 \mathrm{Mg}$ (Appendix 4).

In August 1940, Norm Nevills scouted Lava Falls Rapid as Barry Goldwater photographed the rapid from the aggraded debris fan. The views taken by Goldwater could not be exactly replicated in 1993 because his camera station was $4 \mathrm{~m}$ above the water at the bottom of the rapid; nonetheless, his photographs document a debris fan with a near vertical and slightly reworked distal margin. In his diary, Goldwater notes:

At Lava Falls most of the water flows over to the right bank where it plunges over a fall that 
seems to be twelve or fifteen feet [3.7-4.6 m] high. That of course left only the left side to consider as a possibility of running, and, if that possibility didn't show itself, we faced a portage (Goldwater, 1940, p. 93-94).

Nevills ran the rapid, but his diary does not indicate whether he went right or left. When Nevills returned in 1941, he decided that lining was the "obvious" way to traverse the rapid (Heald, 1948). From the reaction of the first boatman to face the altered rapid, the 1939 debris flow did not change the navigability of Lava Falls Rapid.

All sediment and boulders smaller than $1 \mathrm{~m}$ in diameter deposited by the 1939 debris flow were reworked by the Colorado River in 1941. The net effect of the 1939 debris flow is evident in photographs taken in 1941 and 1942 (figs. 18a and 19a). The upper left side of the rapid, which had quiet water before 1939, became choked with boulders. The V Wave formed (fig. 20), suggesting the 1939 debris flow deposited the Meteor Rock in the rapid. The Deflector Rock moved about $10 \mathrm{~m}$ downstream (fig. 11) and is visible in aerial photographs taken at a discharge of $79 \mathrm{~m}^{3} / \mathrm{s}$ in the 1950s (e.g., fig. 21c). The Big Wave formed as water flowed over the submerged Deflector Rock. The tail waves, which previously flowed straight at the bottom of the rapid, curved to the right after 1939. Owing to the increased constriction, flow on the right side of the rapid increased and impinged directly on the Black Rock. The rapid had fewer boulders for river runners to avoid, but the constriction created more powerful waves. With only a few exceptions, rocks on the right exposed at discharges of greater than $280 \mathrm{~m}^{3} / \mathrm{s}$ were unchanged, and no new boulders were added to the right side.

We could not document the occurrence of any debris flows in the 15-year span from 1939 to 1954. Available photographs of Lava Falls during that period (appendix 1) show no changes and levees deposited in 1939 remained prominent and unchanged.

A small debris flow occurred in Prospect Canyon in 1954. Photographs constrain the date between June 14 and August 29, 1954 (appendix 1; table 4). Georgie White, a long-time river guide (also known as Georgie Clark; Clark and Newcomb, 1977), arrived at Lava Falls on July 24 and saw Prospect Canyon running at "full force."
Large boulders were entering the river in a manner White likened to a "big black lava flow" (Georgie White, unpublished diary of 1954 river trip, Otis Marston Collection, Huntington Library). White's observations are only the second eyewitness account of a Grand Canyon debris flow, after Robert Brewster Stanton's account of a debris flow in South Canyon (Smith, 1965; Smith and Crampton, 1987; Webb, 1996). Péwé (1968) reports a 1967 debris flow near Lees Ferry.

From low level aerial photography the 1954 debris flow appeared to aggrade the channel of Prospect Canyon by about $1.5 \mathrm{~m}$. This debris flow again filled in the previously open left side of the rapid with boulders, which forced the main flow down the right side and constricted the Colorado River to less than half its average width. The tail waves curved farther to the left at the bottom of the rapid. Of more significance to navigation of the rapid, the Ledge Hole began to form. Despite this, the 1954 debris flow decreased the overall severity of Lava Falls (P.T. Reilly, oral commun., 1991). Previous spaces between the large boulders were filled in and the flow became less turbulent with fewer holes scattered around the rapid. The volume of sediment deposited by the 1954 event was the smallest of the six historic debris flows in Prospect Canyon. No depositional evidence remains of this debris flow because of subsequent erosion.

Another debris flow, the second largest of this century, occurred in 1955. The date of the debris flow is constrained by historical photographs taken on July 20 and in October 1955 (appendix 1; table 4). The 1955 debris flow removed or buried all the 1954 deposits and constricted the Colorado River by two-thirds; the rapid was only $20 \mathrm{~m}$ wide in aerial photographs taken during low water on March 25, 1956 (fig. 21b). The deposits from this debris flow constricted the channel of Prospect Canyon by about two thirds and partly overtopped the 1939 debris levee. Many large boulders were deposited in the rapid; some of these now form the Ledge Hole.

The mid-1950s were low-water years on the Colorado River. Several years of winter drought affected much of the United States, particularly in New Mexico, Colorado, and Texas (Thomas, 1962). Discharges in the Colorado River were low and most of the 1955 debris-flow deposit remained on the left side of Lava Falls (fig. 21b). Aerial 


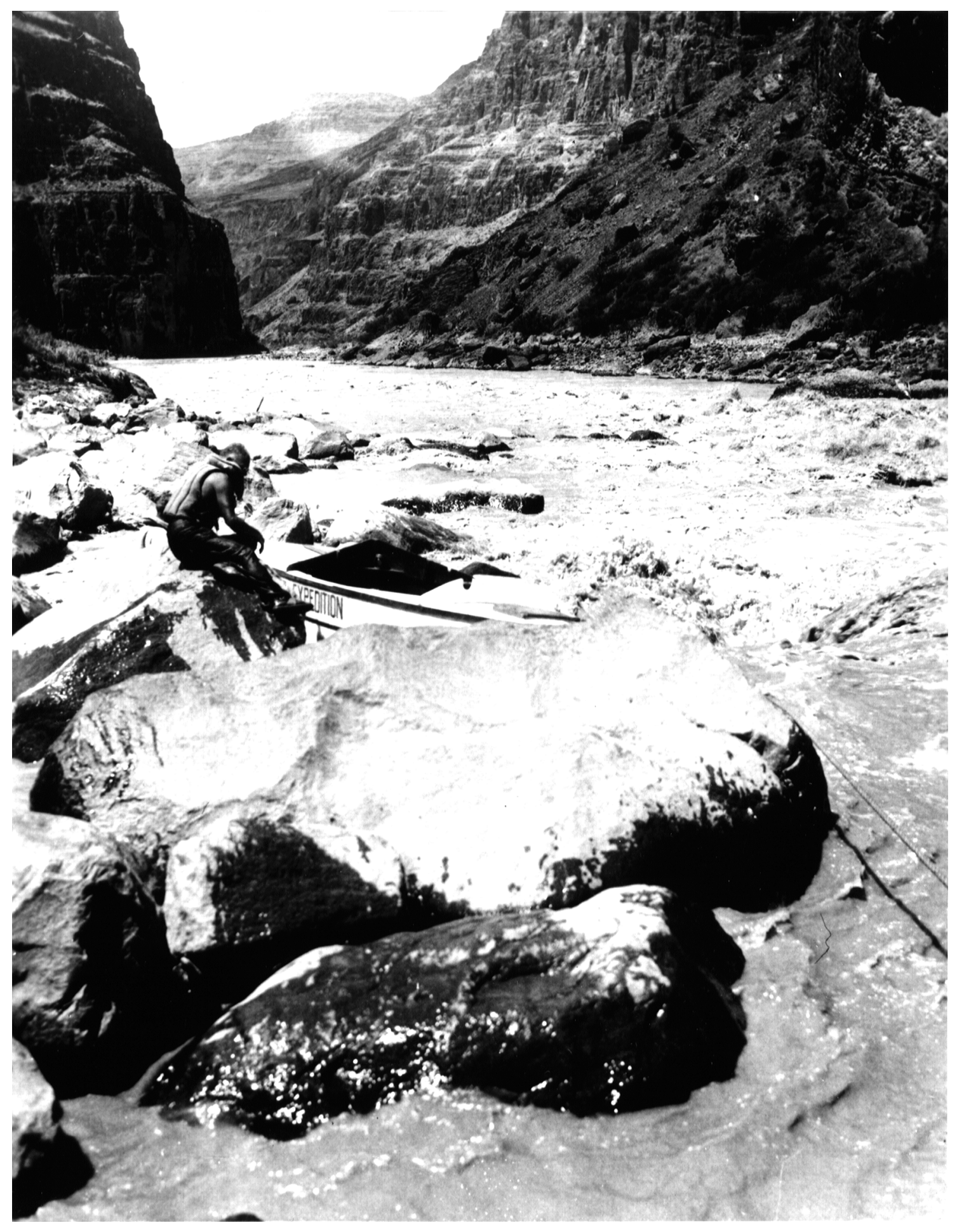

Figure 19. Downstream view of Lava Falls Rapid from the left side (Stake 2741). A. (July 27, 1941; W. Heald, courtesy of the University of Utah Marriott Library). A crew member of the 1941 Nevills expedition rests on a rock during a portage down the left shore. At a discharge of about $570 \mathrm{~m}^{3} / \mathrm{s}$, water is piling up against the Black Rock, shown in the upper right of the view. The pattern of the tail waves, which has changed in comparison to pre-1939 views, is the result of increased constriction of the Colorado River and displacement of the Deflector Rock during the 1939 debris flow. All foreground rocks in this photograph were deposited in 1939. 


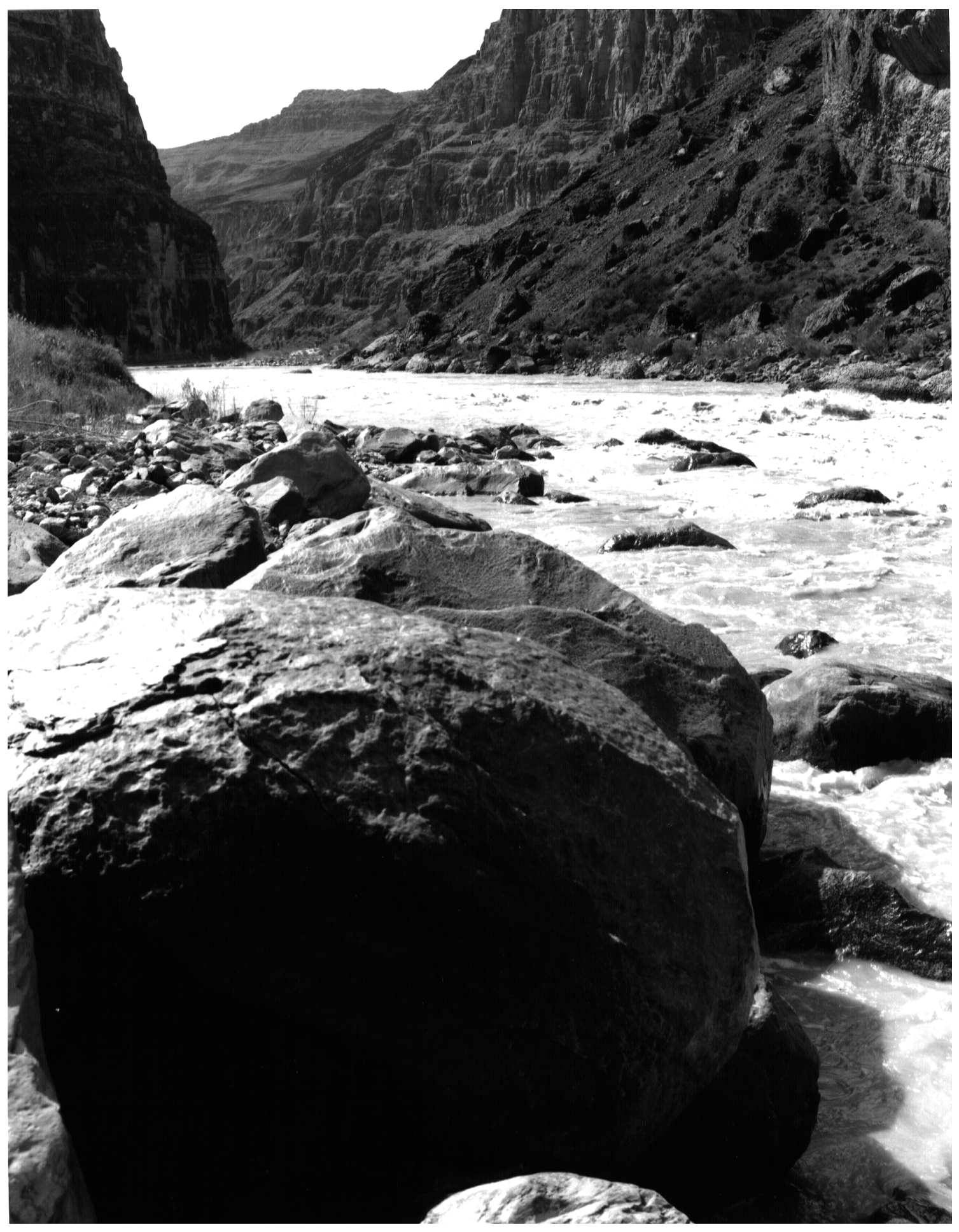

B. (March 10, 1993; S. Tharnstrom). Flow in the Colorado River is about $230-280 \mathrm{~m}^{3} / \mathrm{s}$. Although many boulders have been transported in and out of the field of view by debris flows after 1941, several boulders in the midground remain. The boulder that the crew member is resting on in 1941, as well as the boulders immediately upstream, are in the same place. The foreground boulder, which has a b-axis diameter of $1.85 \mathrm{~m}$, was probably deposited during the 1955 debris flow. The pattern of waves at the bottom of Lava Falls Rapid is similar in 1941 and 1993.

Figure 19. Continued. 


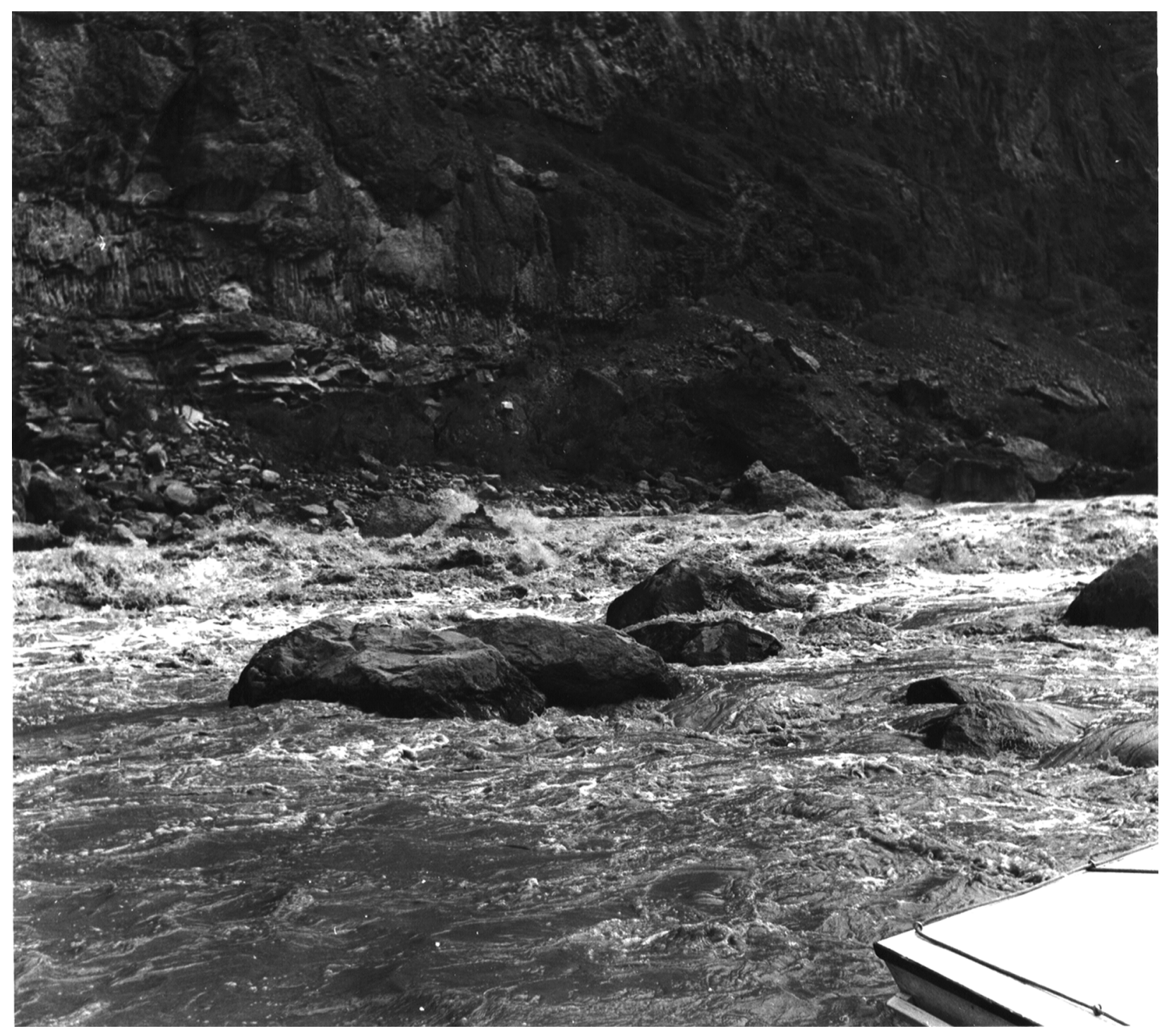

Figure 20. Upstream view of Lava Falls from the left side (Stake 2046).A. (July 7, 1950; P. T. Reilly). A motor boat passes through the $V$ Wave, which appear in the left center of this upstream view. The large boulder at bottom center is approximately $1.5 \mathrm{~m}$ in diameter. The discharge is $470 \mathrm{~m}^{3} / \mathrm{s}$. 


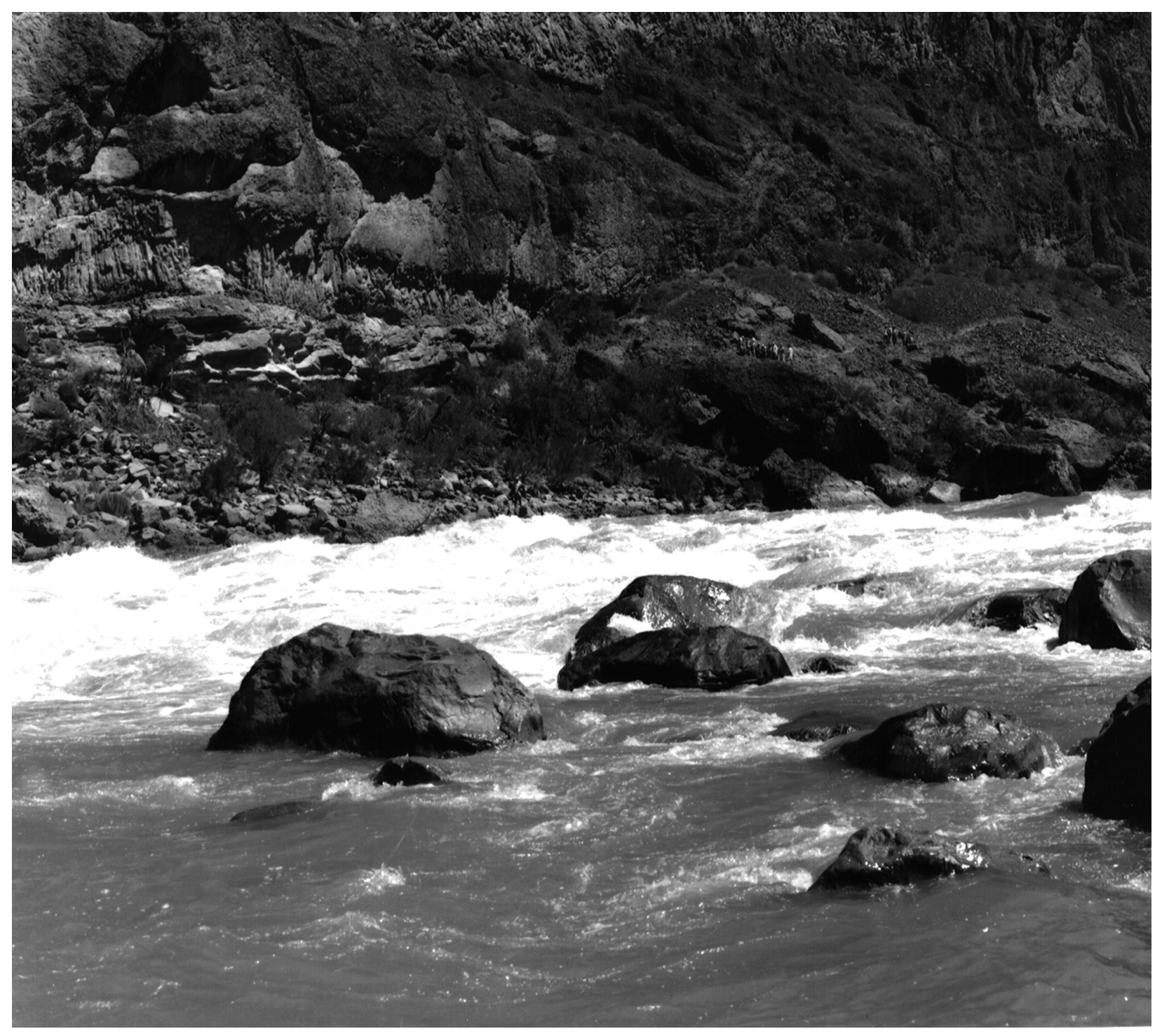

B. (August 16, 1991; R.H. Webb). The discharge is slightly lower than in the 1950 photograph. Several boulders in the foreground were not dislodged by debris flow and Colorado River floods after 1950. However, one foreground boulder has been transported out of the field of view. A boulder of approximately the same dimensions was also transported into the field of view (lower right). Both boulders probably were deposited by the 1955 debris flow.

Figure 20. Continued. 

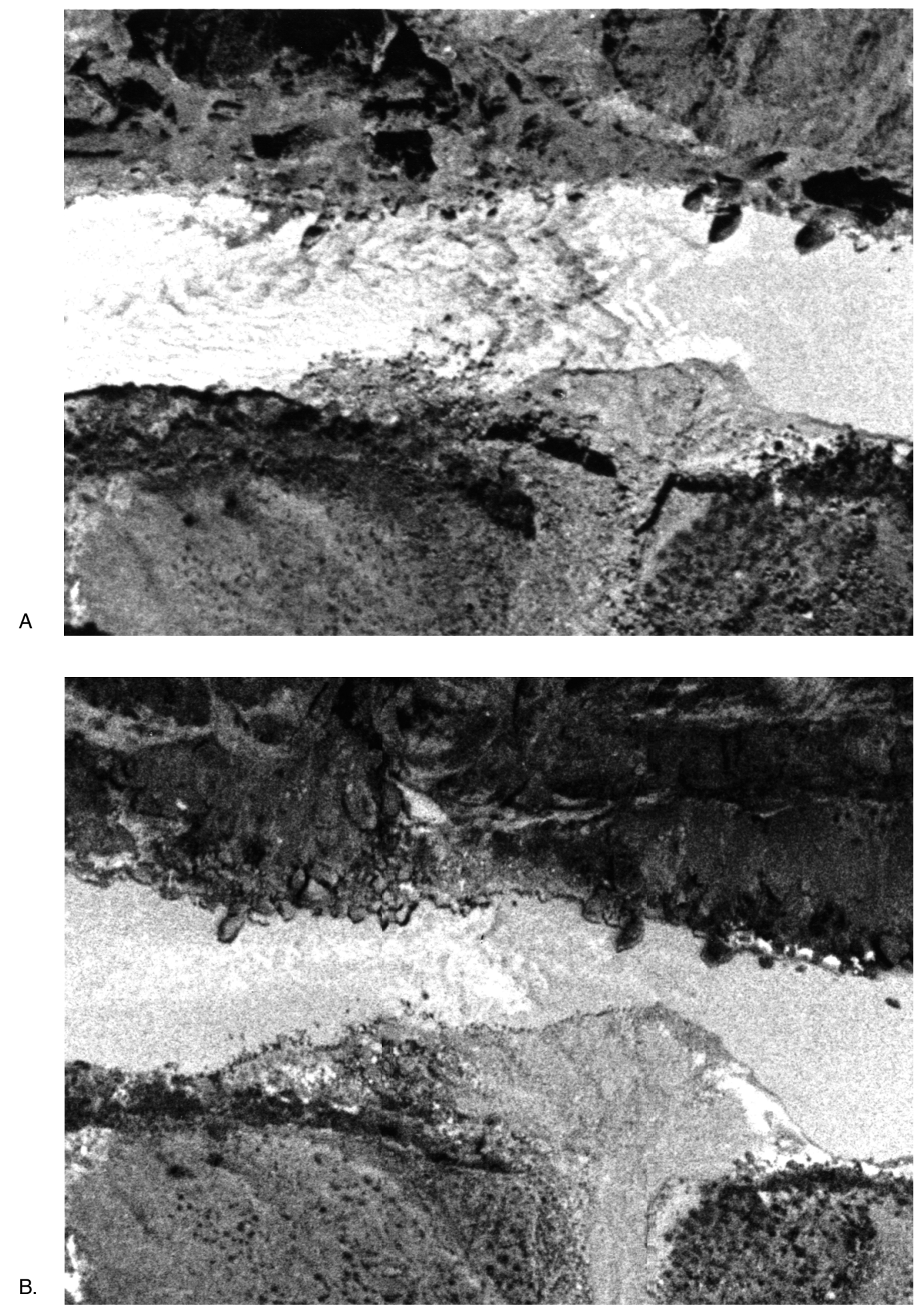

Figure 21. Oblique aerial views of Lava Falls Rapid and Prospect Canyon (P. T. Reilly). A. (March 21, 1955). Although the discharge is $400 \mathrm{~m}^{3} / \mathrm{s}$, the 1954 debris fan (at center) constricts the Colorado River by about 30 percent. The channel of Prospect Canyon (upper left) is a meandering band of fresh debris-flow and fluvial deposits. The tongue at the head of the rapid is on the right side, and the tail waves curve toward the left side at the base of the rapid. B. (March 25, 1956). The 1955 debris flow, which formed a smaller debris fan than the 1939 debris flow, overtopped the 1939 levee on the left side of Prospect Canyon in several places but did not destroy vegetation. The river was at $180 \mathrm{~m}^{3} / \mathrm{s}$ and rising when the photograph was taken; the fan extended farther into the river. 

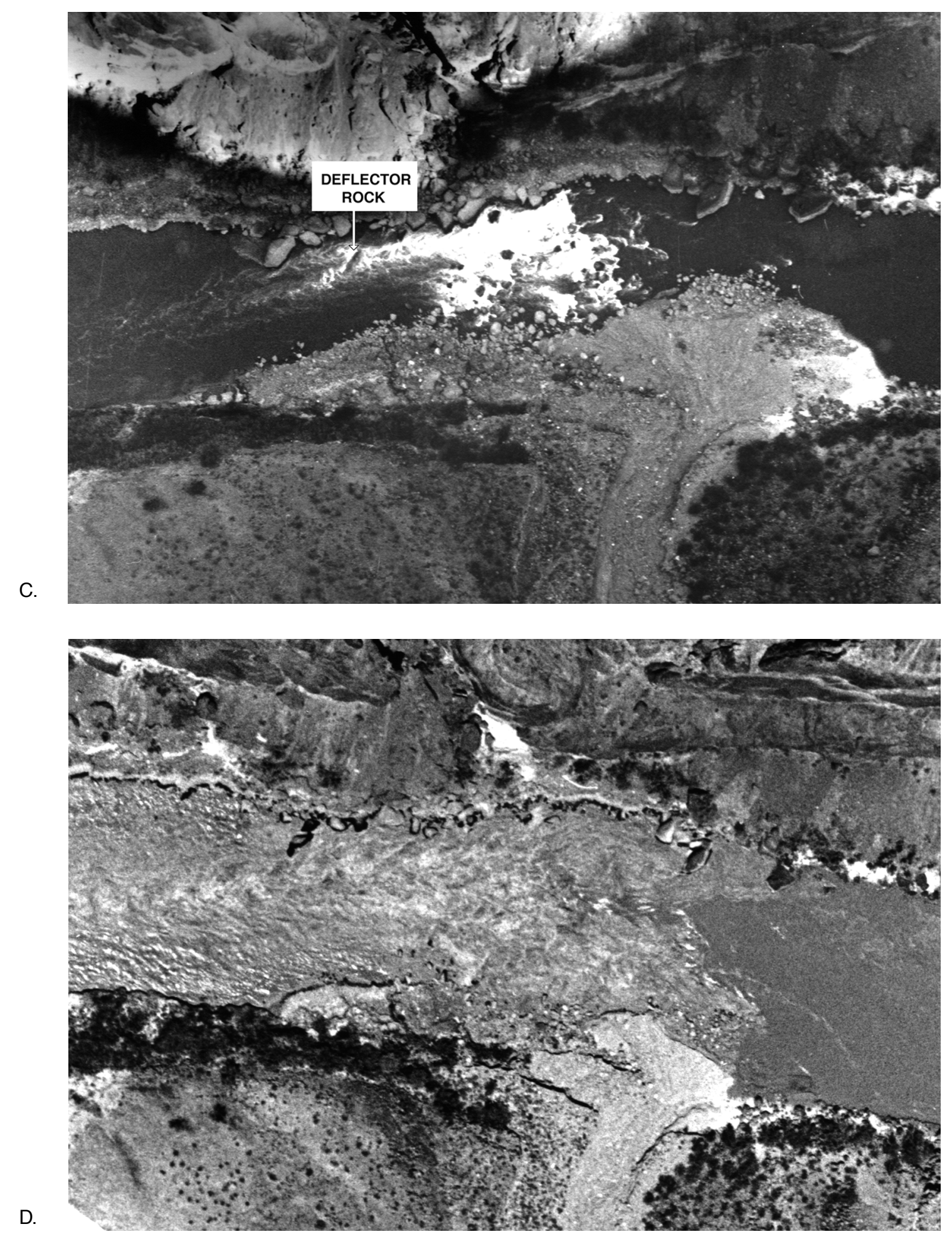

C. (September 29, 1956). The 1956 flood deposit is the fresh-looking material on the upper end of the debris fan. At a discharge of $80 \mathrm{~m}^{3} / \mathrm{s}$, the displaced Deflector Rock is visible upstream from the Black Rock. The view documents the extent of reworking of the 1955 debris flow by the 1956 flood in the Colorado River, which peaked at $1,890 \mathrm{~m}^{3} / \mathrm{s}$. The reworked zone appears as a coarsening of particle size on the distal end of the debris fan. D. (May 4, 1957). Remnants of the 1955 debris-flow and 1956 flood deposits were eroding under the rising waters of the Colorado River $\left(520 \mathrm{~m}^{3} / \mathrm{s}\right)$. The contact of the 1956 deposits and the 1955 debris flow deposits form a dark band penetrating the center of the fan.

Figure 21. Continued. 

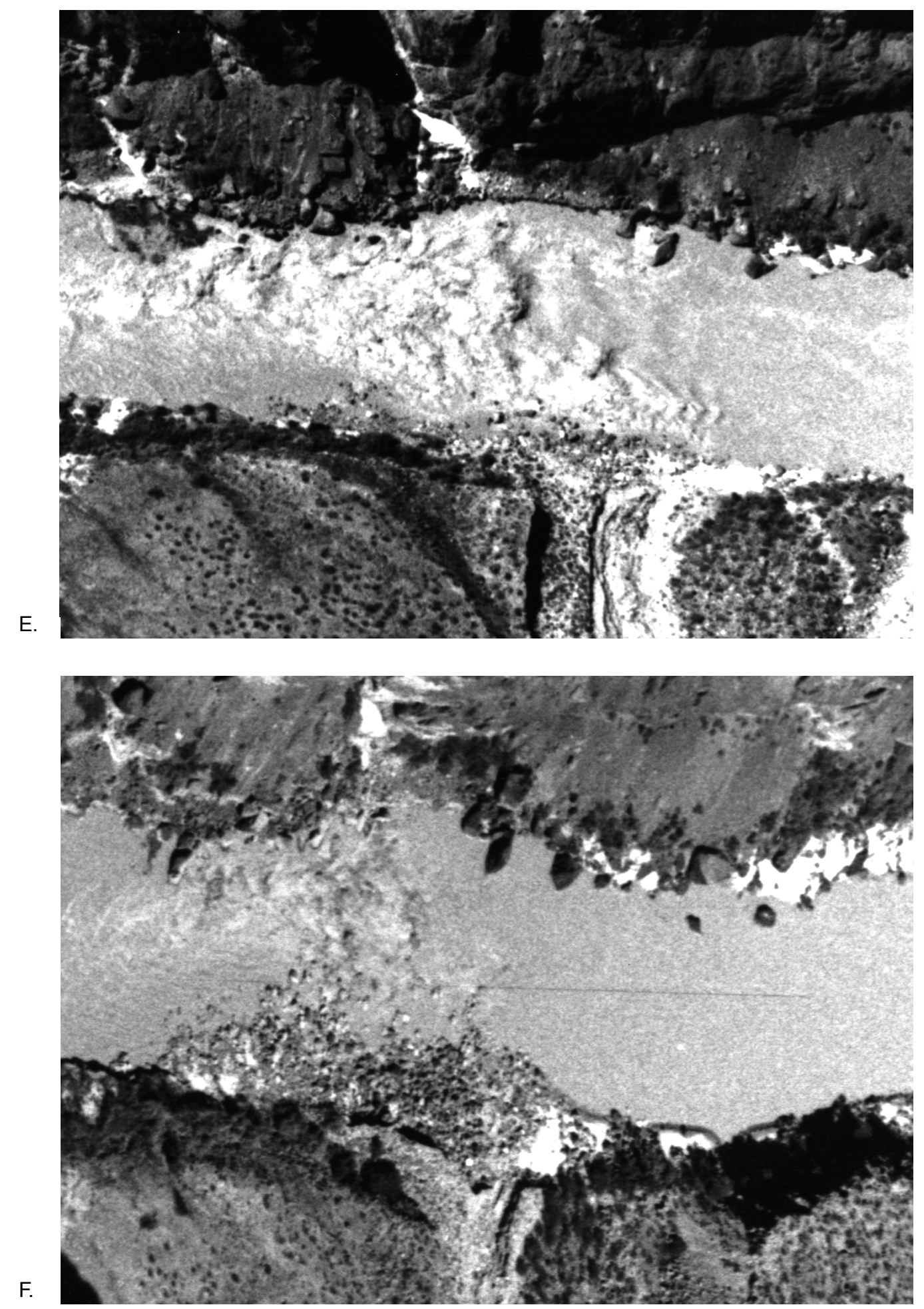

E. (April 20, 1958). The Colorado River peaked at $3,540 \mathrm{~m}^{3} / \mathrm{s}$ in 1957, and the flood removed most of the 1955 and 1956 debris-fan deposits. Small pockets of 1955 levee deposits were still present in April 1958. The Ledge Hole, which formed after the 1957 flood reworked the 1955 deposit, appears in the center of the rapid, which had a discharge of $1,870 \mathrm{~m}^{3} / \mathrm{s}$. F. (October 4, 1958). The Colorado River peaked at $3,030 \mathrm{~m}^{3} / \mathrm{s}$ in 1958, but flow was only $190 \mathrm{~m}^{3} / \mathrm{s}$ when Reilly took his photograph. Only the largest boulders deposited in 1939 and 1955 remained on the debris fan. The Ledge Hole is distinct at the top center of the rapid, and the Big Wave is present in front of the Black Rock.

Figure 21. Continued. 
photographs (fig. 21c) reveal that a flash flood occurred between April 16 and September 29, 1956. With its small deposition, the 1956 flood had little effect on Lava Falls Rapid.

The drought ended in the winter of 1956-1957. The 1957 Colorado River flood peaked at $3,540 \mathrm{~m}^{3} /$ s on June 13. All evidence of the 1954 debris fan and the 1956 flood deposit, as well as most of the 1955 debris fan, was removed (figs. 21a, 21e, and 21f). The flood entrained boulders and other particles smaller than about $1.5 \mathrm{~m}$ in diameter from the Prospect Canyon debris fan and transported them downstream. When the flood receded, only the largest boulders persisted on the left side of the rapid (fig. 22a). The debris fan, which had withstood two years of smaller floods during the drought years, had been reworked to a configuration similar to one that existed before 1954. The large boulders in the middle of the rapid were rearranged to form the Ledge Hole.

After the 1954 and 1955 debris flows, there were no debris flows in Prospect Canyon for 9 years. With closure of Glen Canyon Dam in March 1963, spring floods in the Colorado River were mostly eliminated and peak discharges were reduced. Debris flows continued to occur in Prospect Canyon, the next one between August 24 and September 25, 1963 (appendix 1; table 4). The 1963 debris flow constricted the Colorado River by about two thirds (fig. 23a). The 1963 debris flow had the finest-grained surface deposit of any historic debris flow from Prospect Canyon. Despite the presence of relatively mobile material adjacent to the rapid, most of the deposit was unchanged by low dam releases from 1963 to 1965 (figs. 23b, 24). The 1963 debris fan persisted until a high dam release in June 1965. The debris fan that appears in 1965 aerial photographs is not substantively different from the debris fan shown in photographs taken just before 1963, suggesting that few new boulders were added to the rapid by the 1963 debris flow.

Photographs taken in July 1966 and April 1967 document the occurrence of a small debris flow in Prospect Canyon (appendix 1; table 4; figs. 25a, 26a). The deposition was first observed in March 1967 by the first river runner that year (John Cross II, written commun., 1967). An unusually intense winter storm in December 1966, which caused debris flows in Crystal Creek (mile 98.3), Lava
Canyon (mile 65.5; Cooley and others, 1977; Webb and others, 1989) and elsewhere along the river, is the likely cause for the debris flow. An August 1967 photograph (fig. 26a) shows the extent of the aggraded debris fan. In addition to the poorly-sorted debris fan, small boulders were deposited on the left side of Lava Falls Rapid, reportedly closing off a previously used run (John Cross II, written commun., 1967). Most of the 1966 debris fan was removed by relatively small dam releases in 1972 and a small flood in the Little Colorado River in 1973.

\section{QUIESCENCE (1966-1995)}

Only a few small streamflow floods occurred in Prospect Canyon between 1966 and 1995, the period when most river runners navigated Lava Falls. During February 1993, a streamflow flood in Prospect Canyon deposited a small volume of cobbles on the debris fan. Although some scouring occurred in the bed of Prospect Canyon, Lava Falls Rapid was unchanged.

\section{The 1995 Debris Flow}

Lava Falls Rapid changed dramatically in the early morning hours of March 6, 1995, when a debris flow initiated in Prospect Canyon aggraded the debris fan and constricted the rapid (Webb and Melis, 1995). The authors were camped at the rapid during the debris flow and observed some of its effects immediately afterward. The storm also caused flooding in eastern Grand Canyon (Rihs, 1995) similar to the 1966 flood (Cooley and others, 1977). Of the six historic debris flows in Prospect Canyon, the 1995 debris flow was unique: it entered the Colorado River at a higher river discharge (490 $\mathrm{m}^{3} / \mathrm{s}$ ) than during the previous five.

On March 5, steady rainfall began at midnight and continued through the day at Lava Falls Rapid. The storm culminated in steady heavy rainfall that began about 6 PM and continued until after midnight on March 6. Although daily precipitation was not excessive at Peach Springs and Seligman, precipitation was heavy at Grand Canyon and Bright Angel Ranger Station (appendix 3); a total of 43 $\mathrm{mm}$ fell during the early morning hours of March 6 


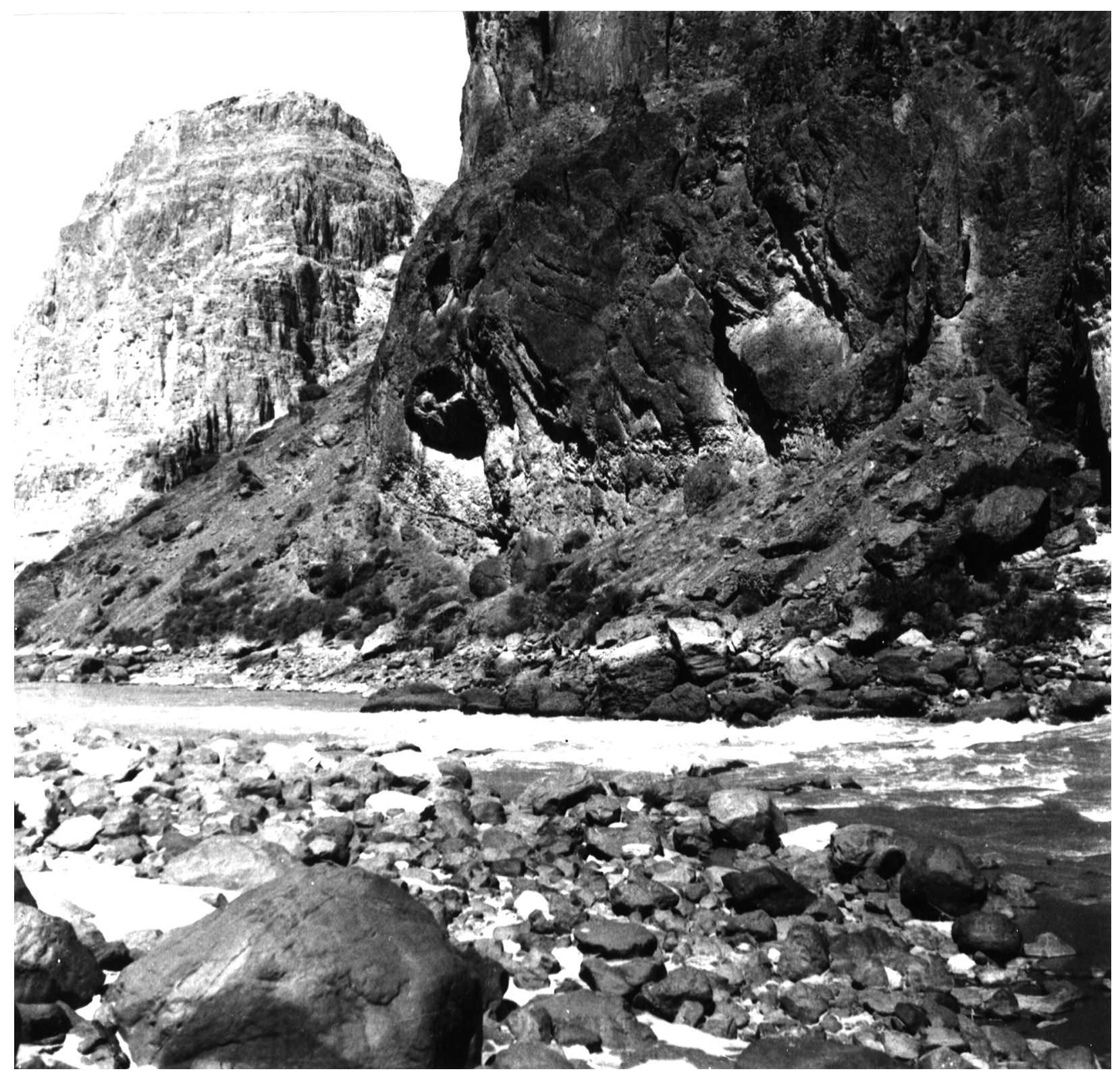

Figure 22. Downstream view of Prospect Canyon debris fan and lower Lava Falls Rapid (Stake 2002). A. (July 20, 1958; G. Staveley, courtesy of the Huntington Library). The discharge is $220 \mathrm{~m}^{3} / \mathrm{s}$, and the boulders on the debris fan are the net result of the 1939, 1954, and 1955 debris flows and reworking by the Colorado River. The 1957 flood in the Colorado River reworked the deposits of the 1954 and 1955 debris flows 


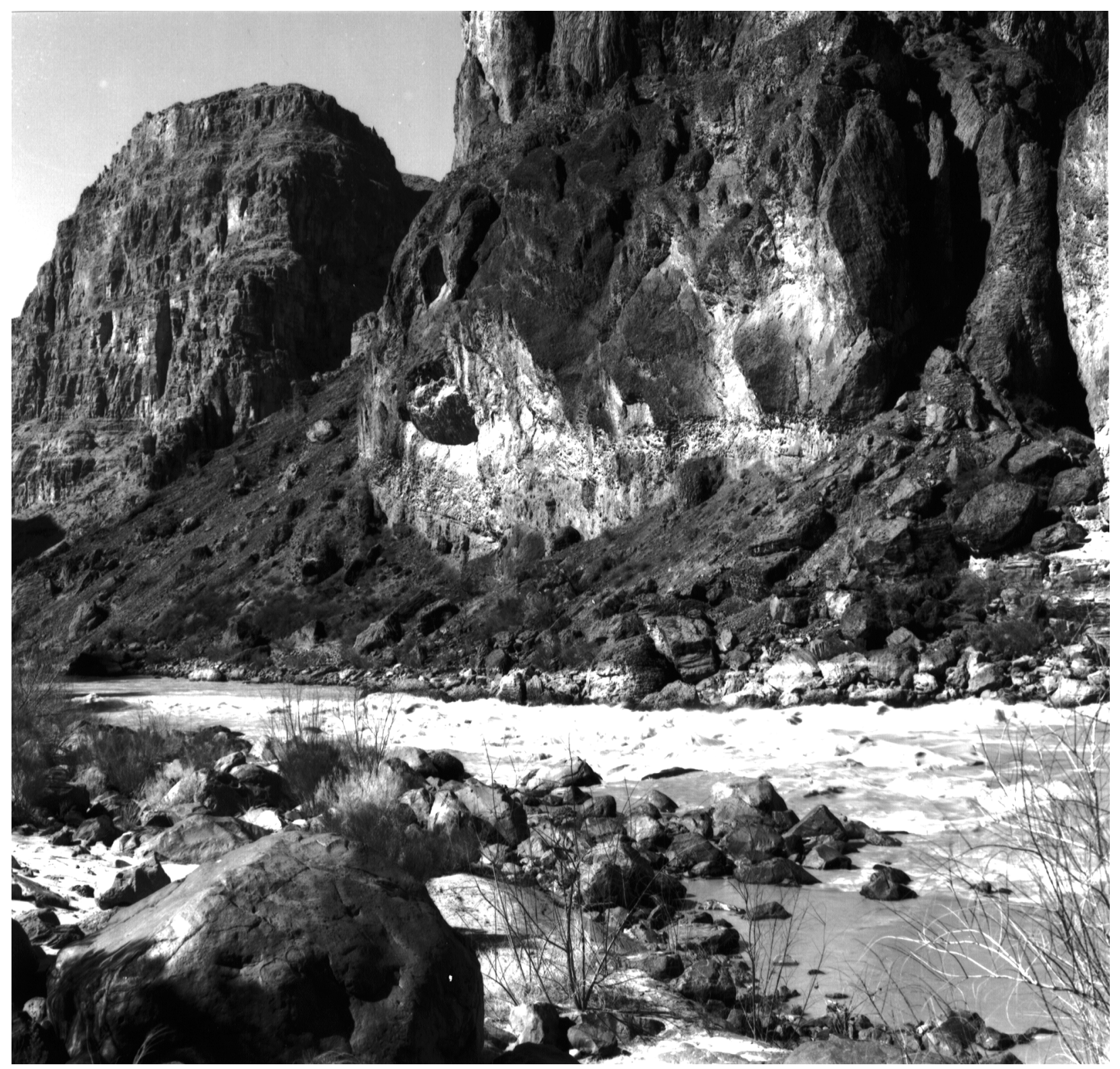

B. (February 20, 1991; D. Edwards). Although the stage was about $0.5 \mathrm{~m}$ higher than in the 1958 view, $6-10$ boulders with diameters of $1 \mathrm{~m}$ or larger remain. Most of the foreground debris fan was buried by debris flows in 1963 and 1966. The debris fan decreased in size slightly between 1958 and 1991 although the size of boulders in the reworked zone appears unchanged.

Figure 22. Continued. 


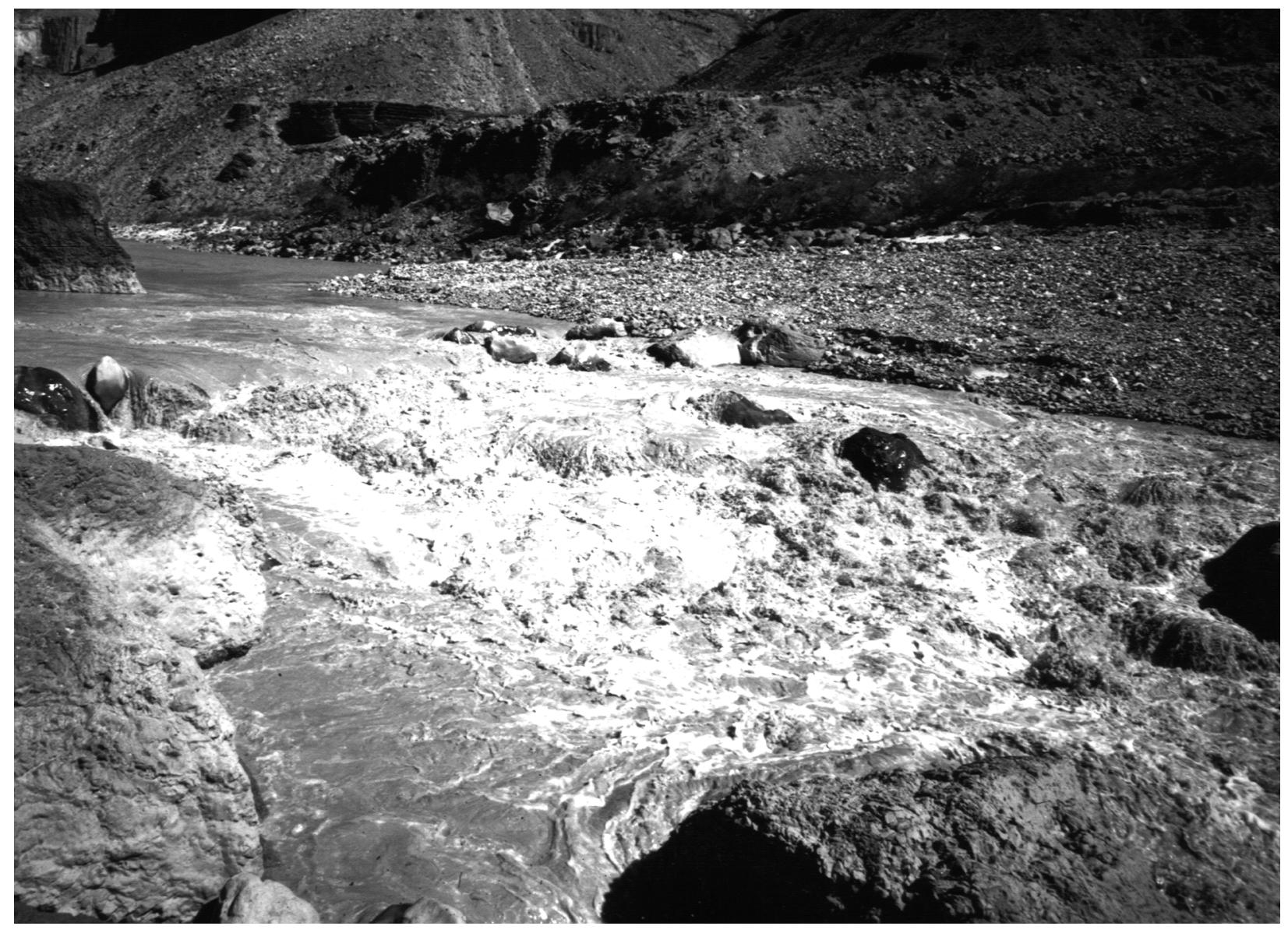

Figure 23. Upstream view of Lava Falls Rapid from the right side (Stakes 2005 and 3050). A. (September 25, 1963; photographer unknown, courtesy of the Huntington Library). This photograph was taken a short time after the September 1963 debris flow and shows its maximum constriction at a discharge of about $56 \mathrm{~m}^{3} / \mathrm{s}$. Boulders on the distal margin of the debris fan and in the center of the view created the Ledge Hole at higher discharges. The Meteor Rock, which creates the $\mathrm{V}$ Wave, appears on the right side of the view. The view shows the relatively fine-grained particle size that is characteristic of the 1963 deposits. 


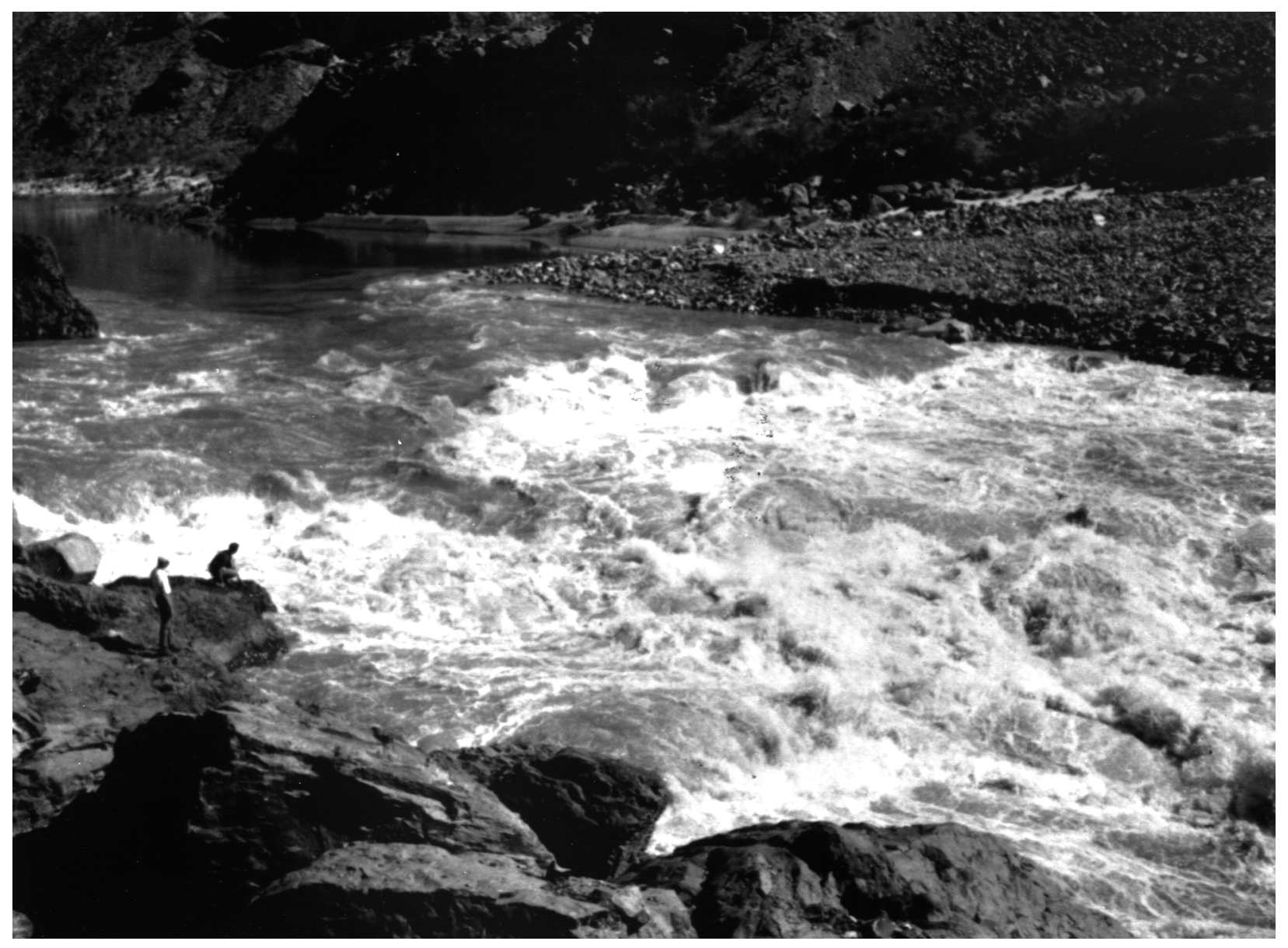

B. (February 21, 1965; J. Visbak, courtesy of the Huntington Library). This view, which is not a match of A, shows Lava Falls at a discharge of about $198 \mathrm{~m}^{3} / \mathrm{s}$. Dam releases up to $550 \mathrm{~m}^{3} / \mathrm{s}$ eroded the distal edge of the debris-flow deposit from 1963 through early 1965. Unlike the 1939 and 1955 debris flows, photographic evidence suggests that few boulders greater than $1 \mathrm{~m}$ in diameter were transported in the 1963 debris flow. As a result, most boulders in the 1963 debris flow fan were entrained during high dam releases in May-June, 1965.

Figure 23. Continued. 


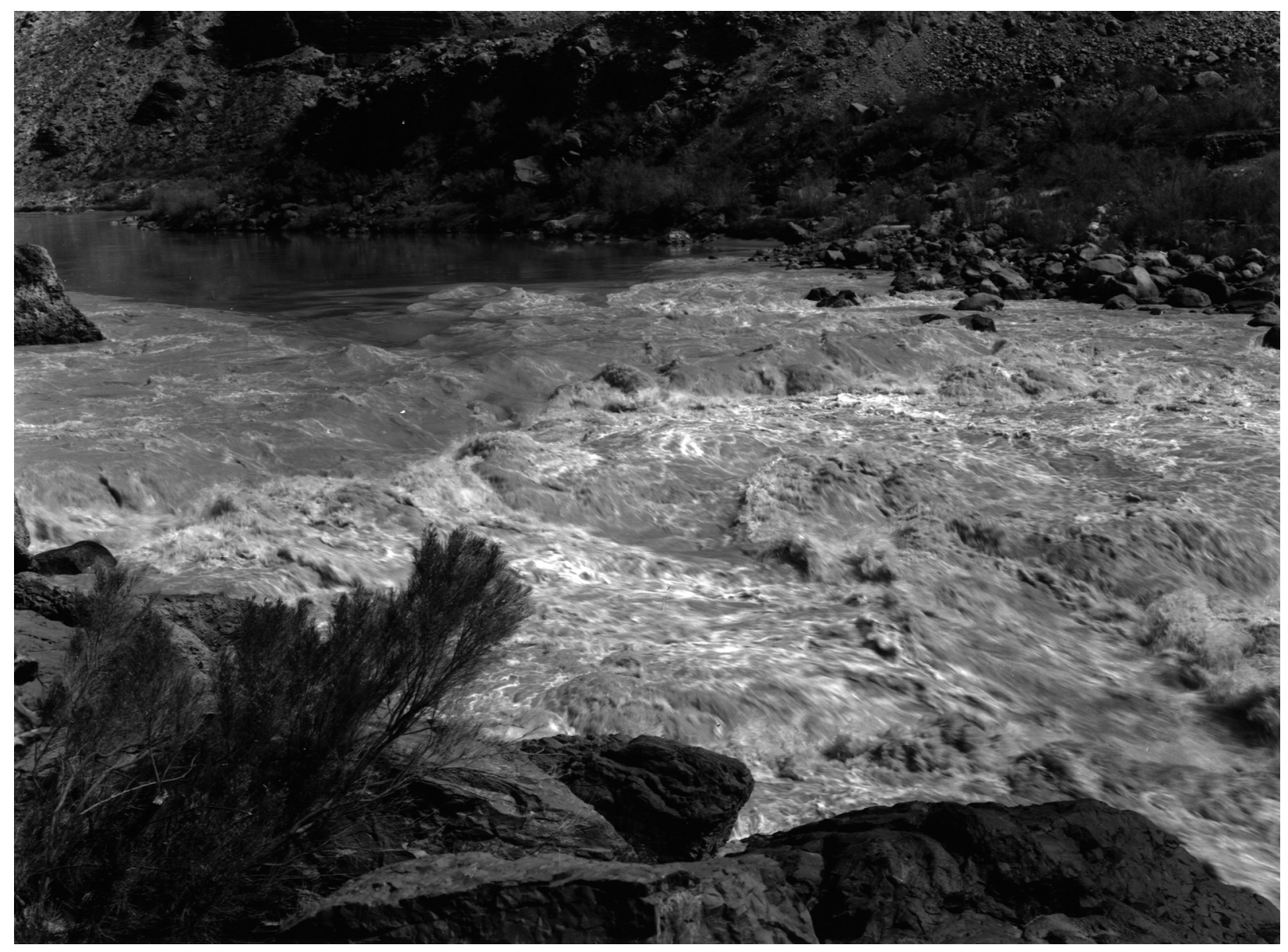

C. (March 10, 1993; L. Hymans). The discharge was about $350 \mathrm{~m}^{3} / \mathrm{s}$ in this match of the 1963 view. Reworking of the 1963 and 1966 debris-flow deposits was complete by that time, leaving little evidence of the former constriction. The boulders forming the Ledge Hole are submerged in this view but their hydraulic effect is clearly visible in the center of the view. The Meteor Rock was also covered, but the noteworthy hole that forms downstream of the Meteor Rock is visible.

Figure 23. Continued. 


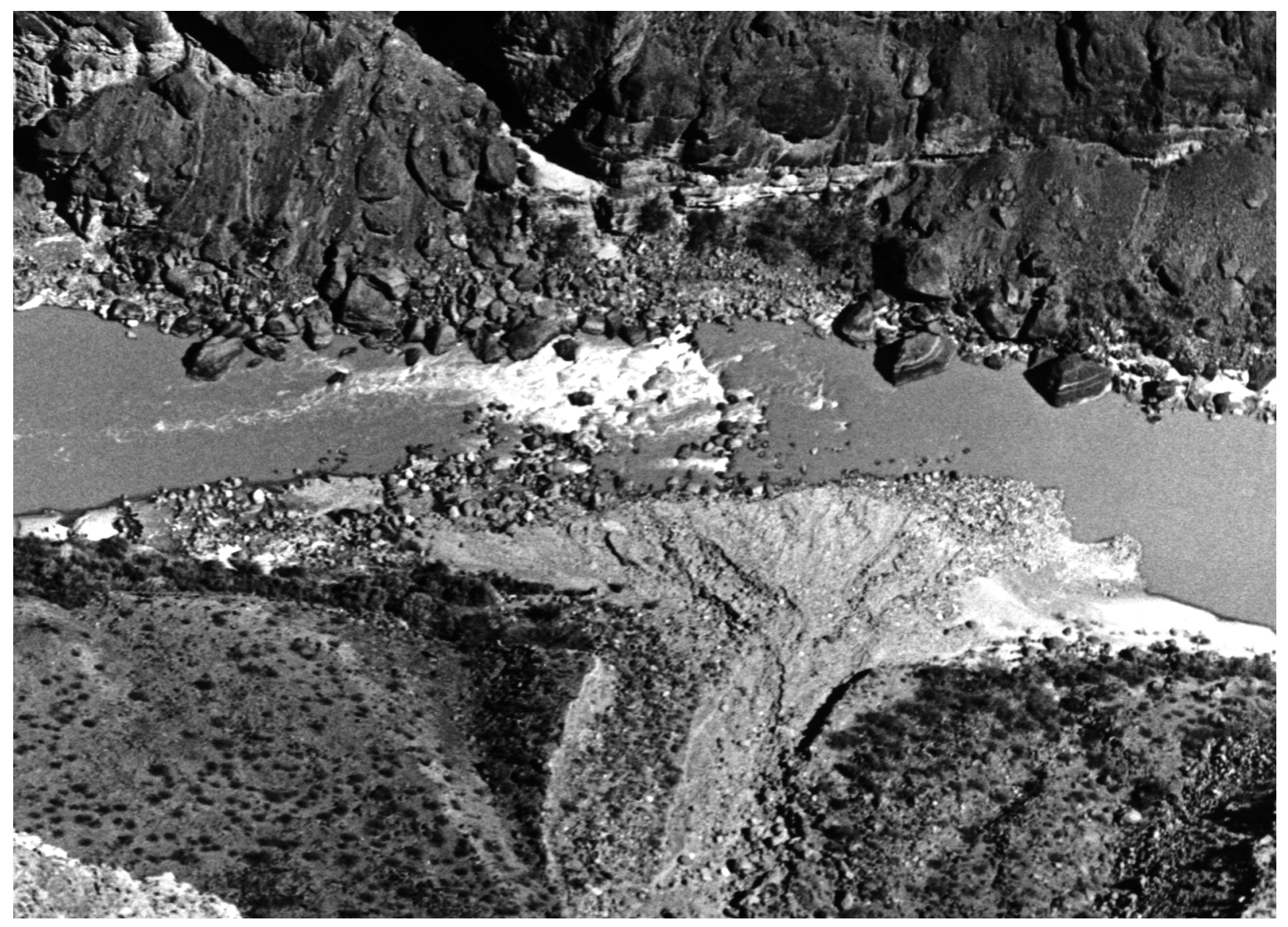

Figure 24. Oblique aerial view of Lava Falls Rapid and Prospect Canyon (May 20, 1964; P. T. Reilly). At a discharge of $37 \mathrm{~m} / \mathrm{s}$, the 1963 debris-flow deposit constricts the river by about 60 percent; the debris fan initially extended nearly to the middle of the Ledge Hole. This view shows the reworking by a peak discharge of $540 \mathrm{~m}^{3} / \mathrm{s}$. The Meteor Rock is visible in the center of the rapid, and the typically submerged Deflector Rock divided the tail waves.

at Tuweep Ranger Station. Between 1:00and 1:30 AM, we heard a roaring sound 3-5 min long from Prospect Canyon; part of the noise sounded like rockfall.

Throughout the following morning, a waterfall in two distinct cascades over a 325 -m cliff jetted what we estimated to be $10-30 \mathrm{~m}^{3} / \mathrm{s}$ of sedimentladen streamflow into the upper part of Prospect Canyon (fig. 27). A later inspection of the channel above the waterfall suggested that gravel and small cobbles were the largest particles transported over the waterfall. Runoff from Prospect Canyon lasted 18-20 hrs and stopped after dark on March 6.

At 6:00 AM on March 6, the new debris fan at Lava Falls Rapid extended $32-50 \mathrm{~m}$ into the Colorado River, which had a discharge of 540 $\mathrm{m}^{3} / \mathrm{s}$. Deposition reached the left edge of the Ledge Hole, and the debris fan covered about $200 \mathrm{~m}$ of the left side the rapid (fig. 11b). The fan sloped continuously into the river with no cutbank on its margin or a break in slope. As the morning progressed, the distal margin of the debris fan was cut laterally by $7-8 \mathrm{~m}$, leaving a $2.6 \mathrm{~m}$ high cutbank on the left side of the rapid. Throughout the morning, large sections of the new fan were undercut and fell into the rapid. Recessional flow in Prospect Canyon cut two channels through the debris fan, further reducing its size. Tributary floodwater entering on the left side of the rapid contributed to the failures of the distal margin. By about 1:00 PM on March 6, the debris fan had stabilized (fig. 28b).

Flow in the river was confined to a channel about 50 percent of its previous width, which caused distinct changes to the hydraulics of Lava Falls Rapid. The water-surface profile (fig. 29a) initially was greatly influenced by large waves on 


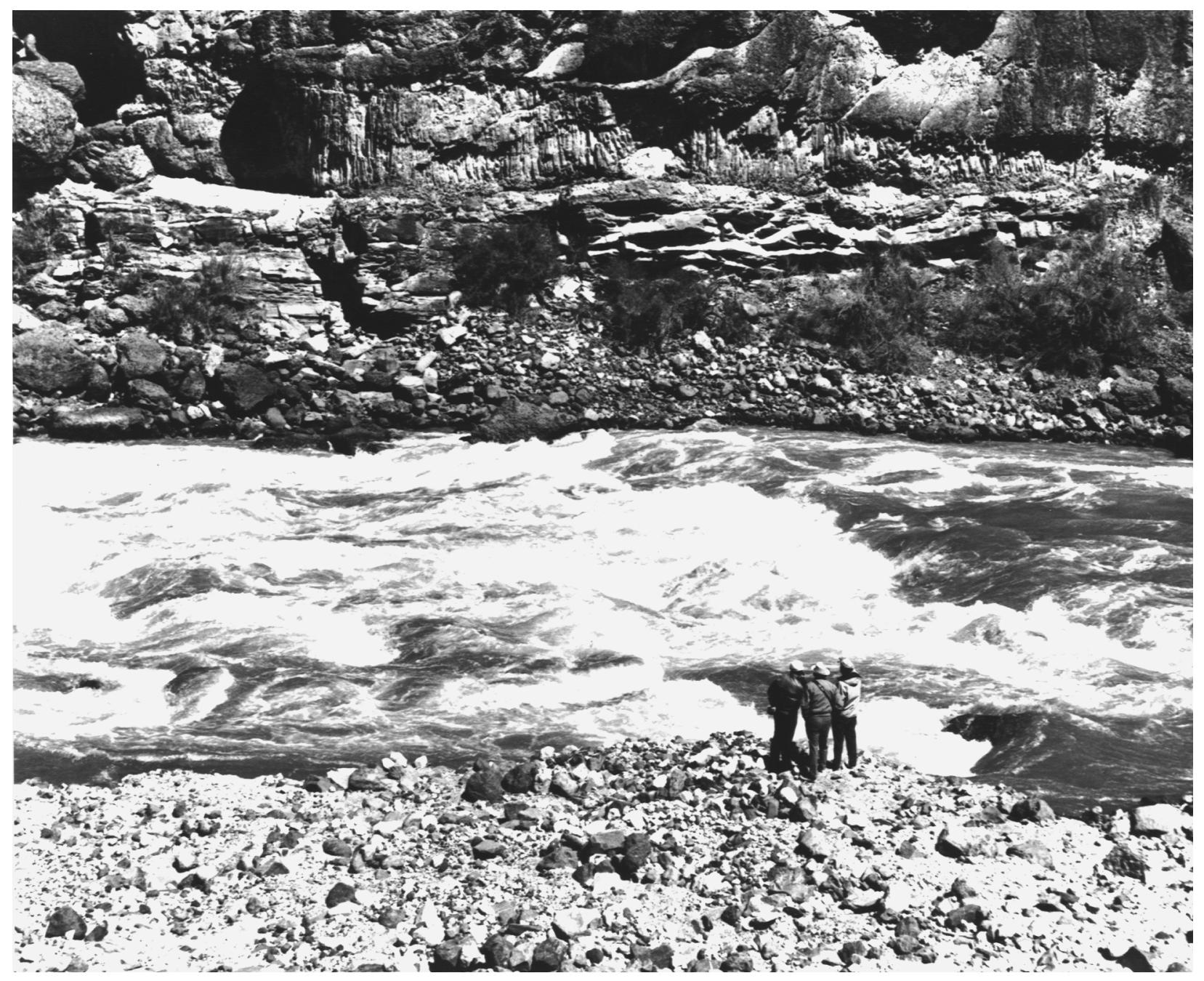

Figure 25. View from the left side across the top of Lava Falls Rapid (Stake 2739). A. (April 30, 1967; D. Harris). The crew of this 1967 trip stands on the 1966 debris-flow deposit while scouting routes through the rapid, which had a discharge of about $280 \mathrm{~m}^{3} / \mathrm{s}$. The largest visible boulder in the 1966 deposit is less than $1 \mathrm{~m}$ in diameter. 


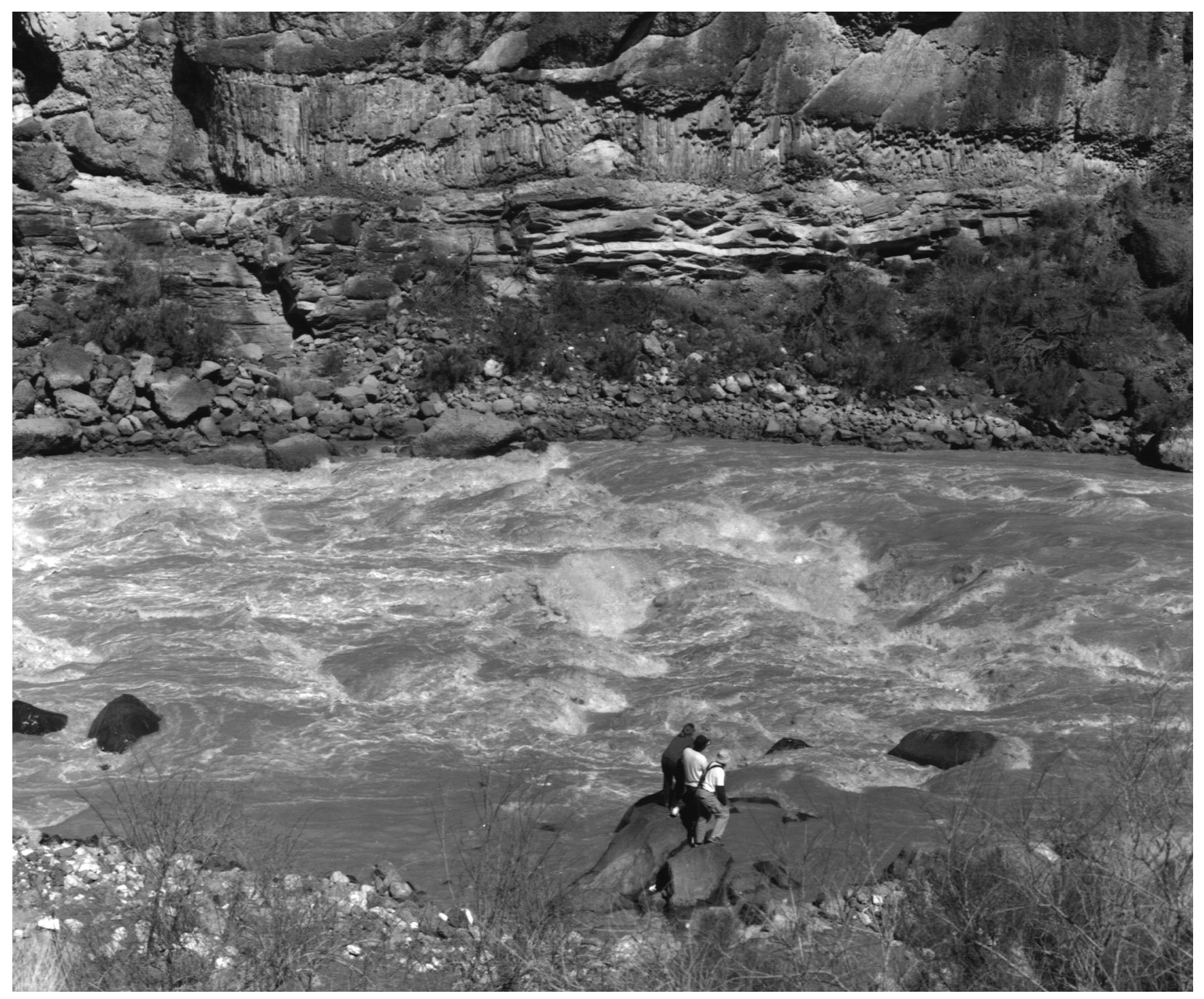

B. (March 8, 1993; R.H. Webb). The discharge was slightly lower than that in 1967. Most of the 1966 debris-flow deposit was removed in April 1973; the 1983 flood $\left(2,720 \mathrm{~m}^{3} / \mathrm{s}\right)$ caused few changes in Lava Falls. The largest boulders, which controlled the major waves and holes in the rapid, were unchanged.

Figure 25. Continued. 


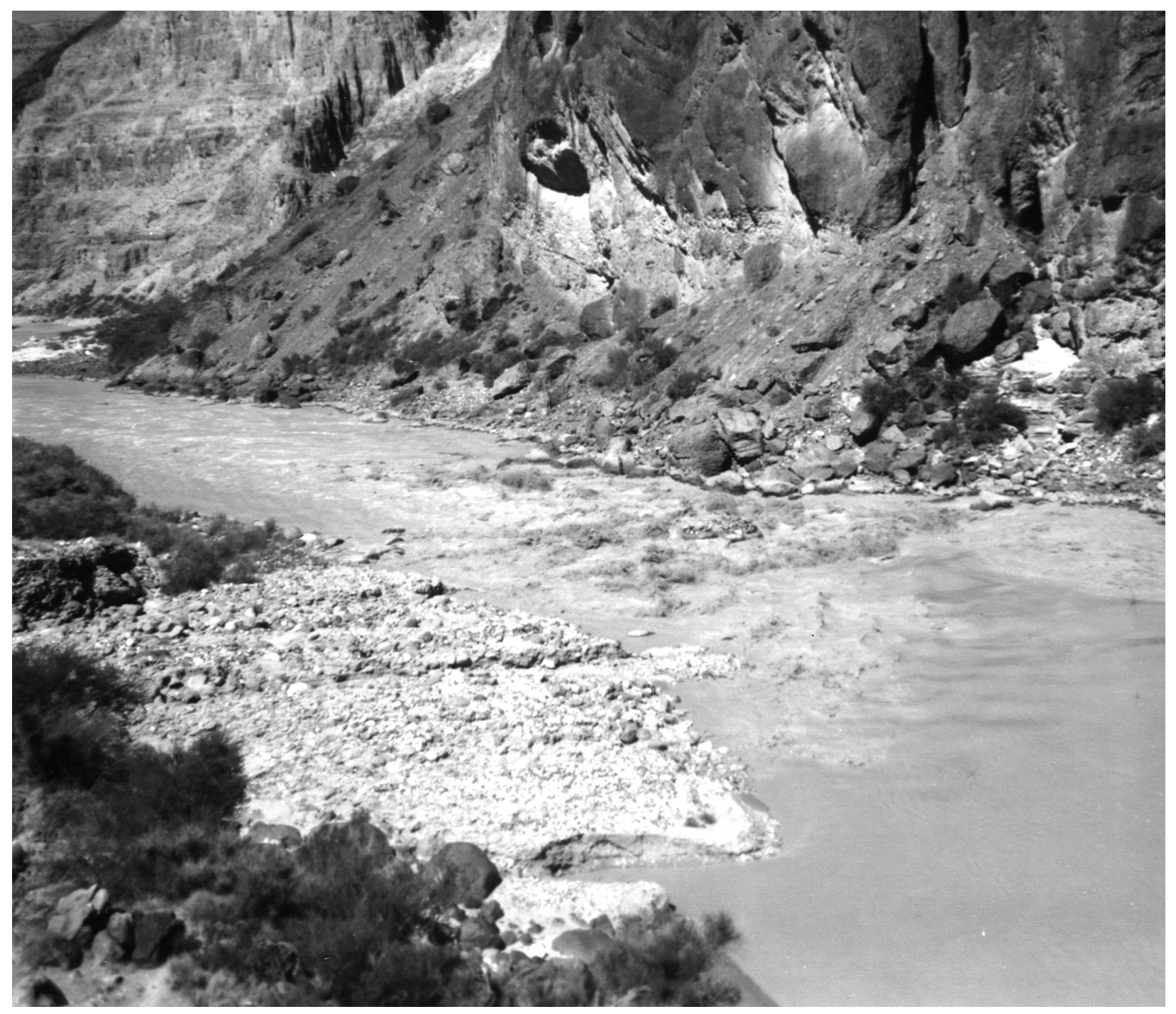

Figure 26. Downstream view of Lava Falls Rapid from the high surface on the left side (Stake 2964b). A. (August 1967; G. Luepke). At a discharge of about $340 \mathrm{~m}^{3} / \mathrm{s}$, the 1966 debris flow constricts the Colorado River by about 36 percent. According to the first river runner to view the rapid, the only effect of this debris flow was to eliminate the Left Run. A typical dam release and a small flood in the Little Colorado River on April 19, 1973, combined to form a peak discharge of $1,080 \mathrm{~m}^{3} / \mathrm{s}$, which removed the 1966 deposit. 


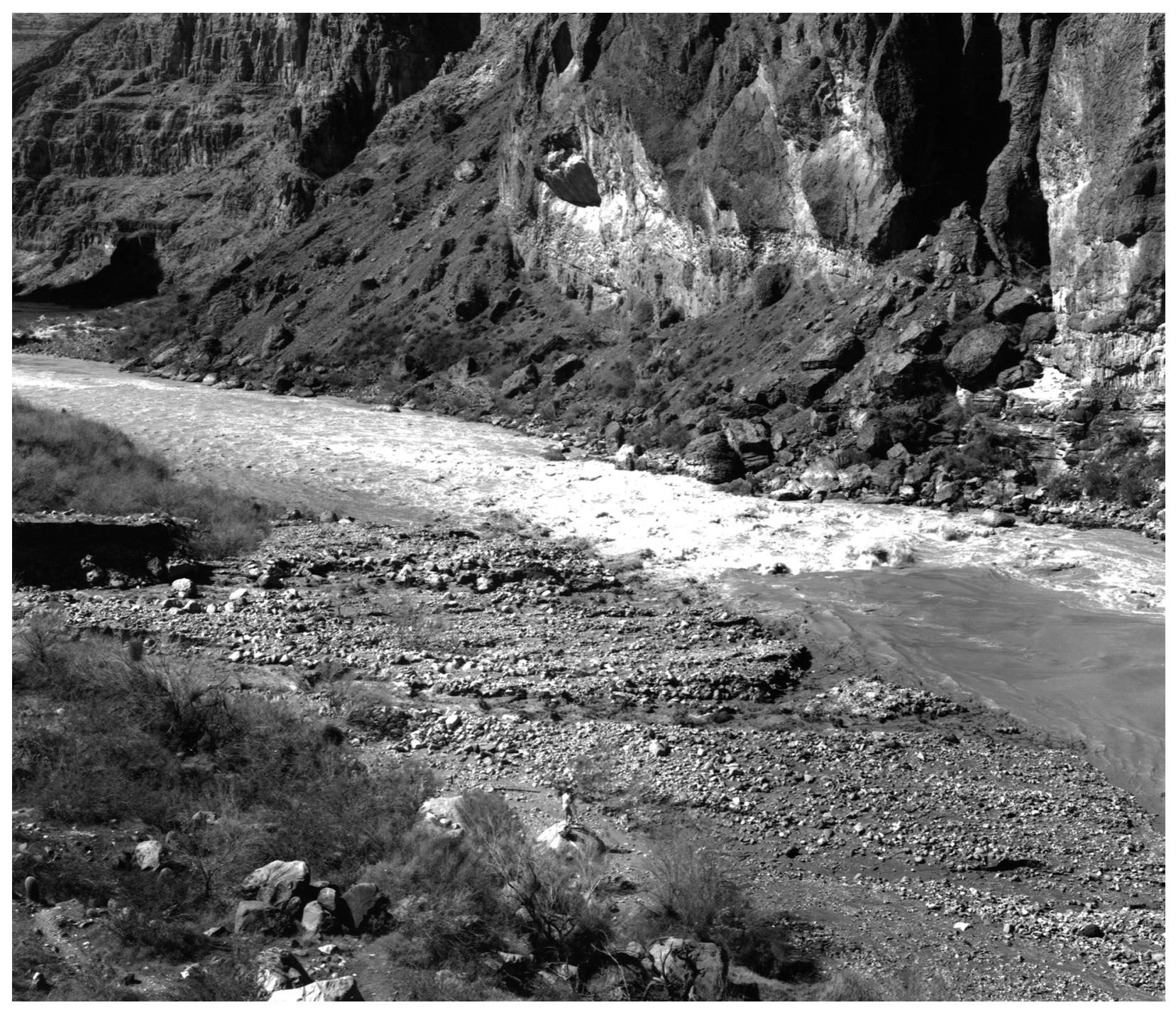

B. (March 6, 1995; R.H. Webb). The deposit of the March 1995 debris flow was much larger than that of the 1966 event, but the shape is remarkably similar. The amount of sediment deposited in 1995 is about half the amount deposited during the 1955 debris flow.

Figure 26. Continued. 


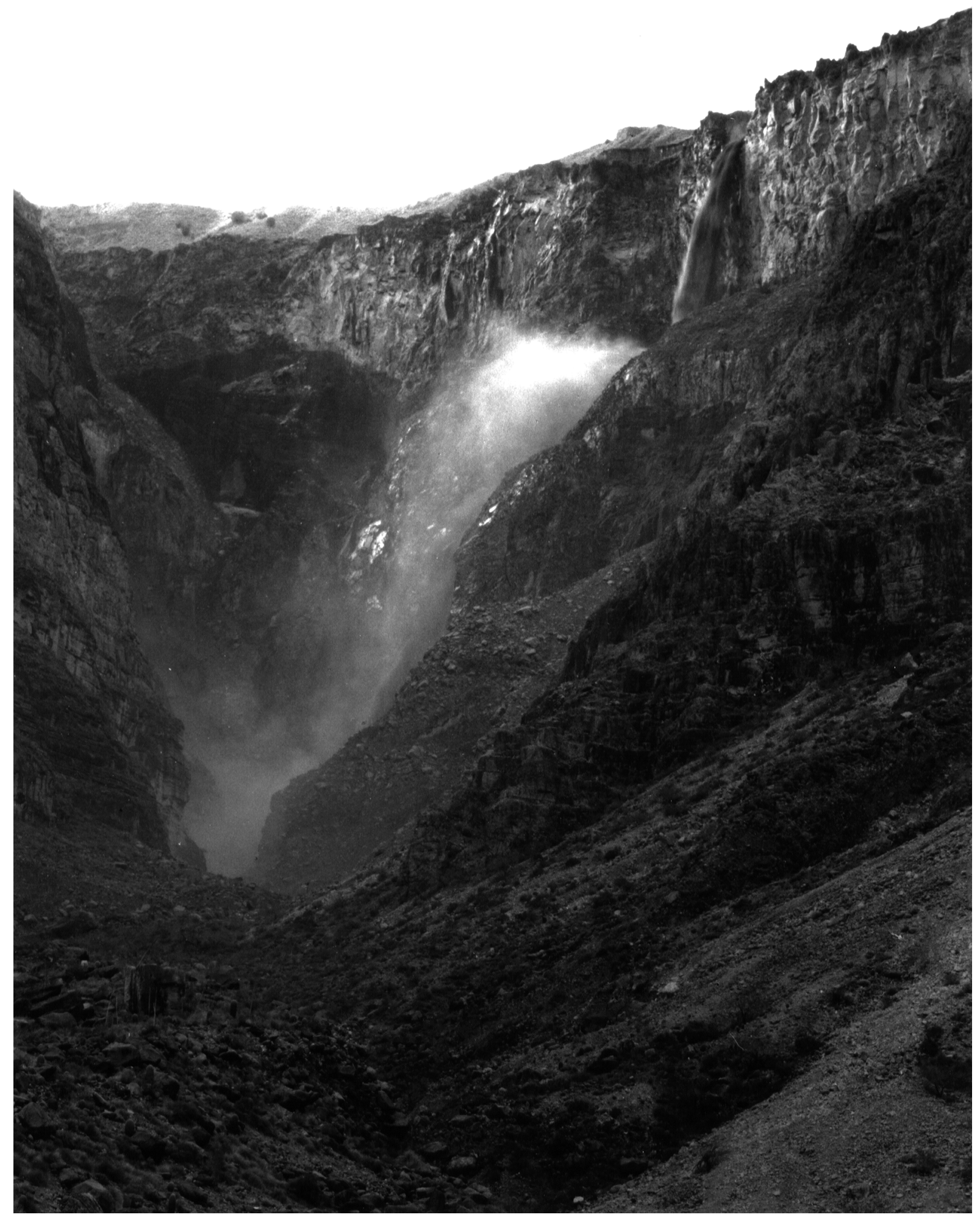

Figure 27. (March 6, 1995; S. Tharnstrom). The firehose effect created by streamflow falling over a 325-m fall at the head of Prospect Canyon on March 6, 1995 


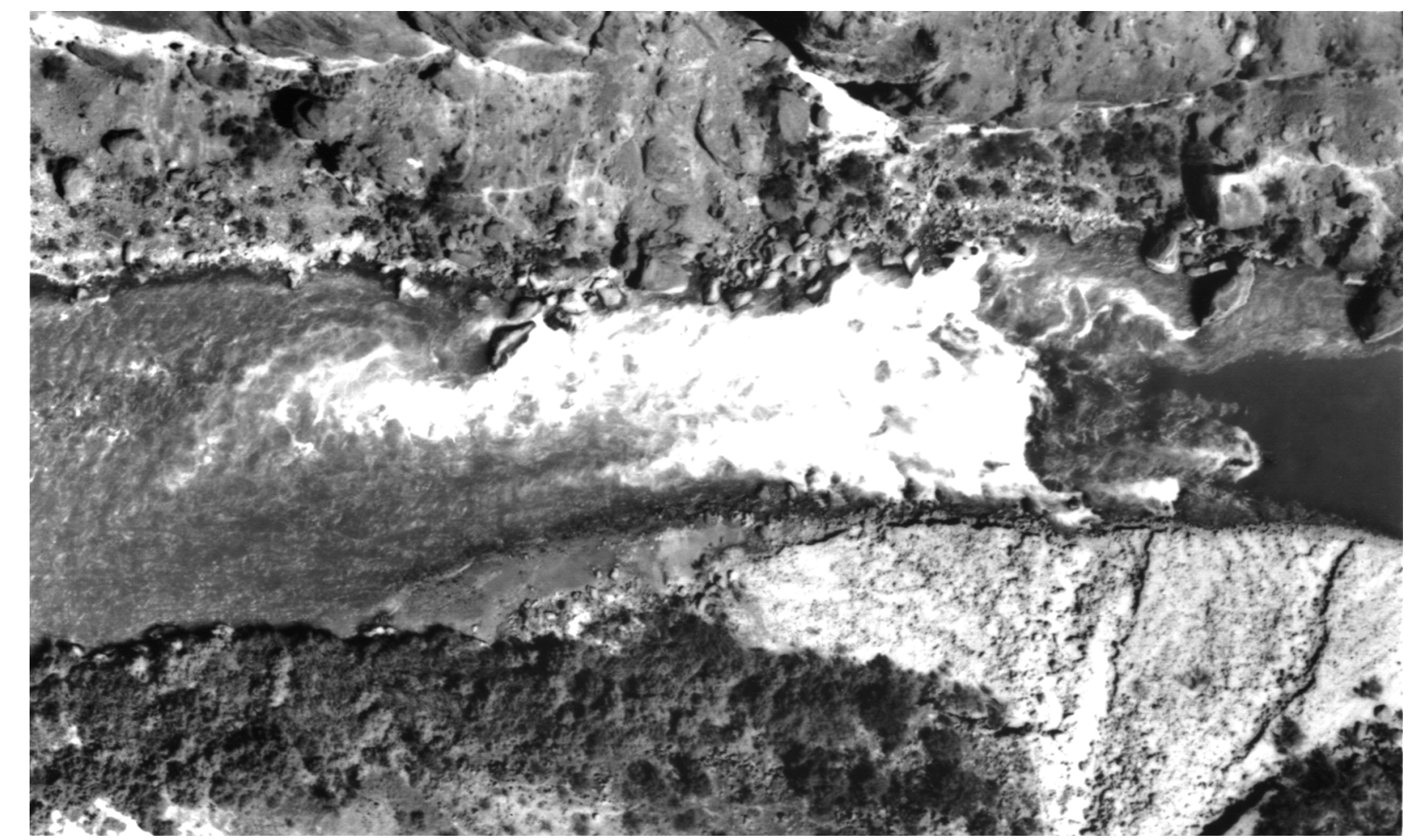

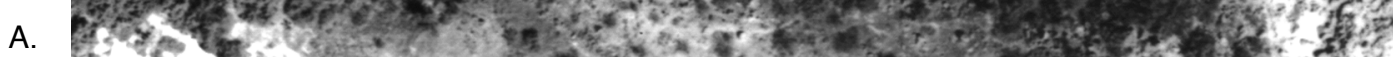

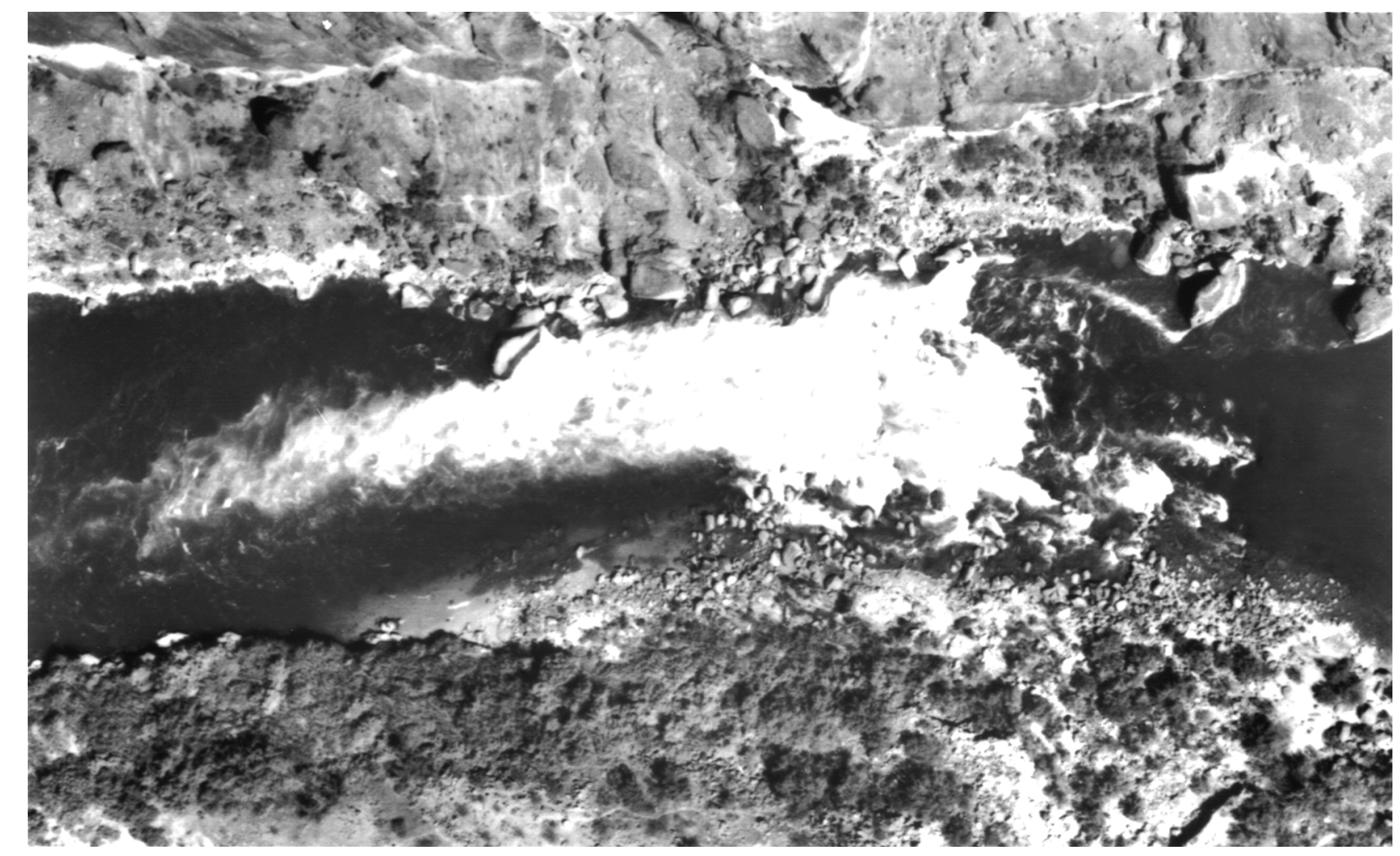

Figure 28. Vertical aerial photographs of Lava Falls Rapid. A. (June 1, 1994). Before the 1995 debris flow, the rapid had a constriction of 28 percent at a discharge of $230 \mathrm{~m}^{3} / \mathrm{s}$. B. (May 30, 1995). After the 1995 debris flow, Lava Falls Rapid had a 50 percent constriction at a discharge of $260 \mathrm{~m}^{3} / \mathrm{s}$. The debris fan did not change significantly between March 8 and May 30. 


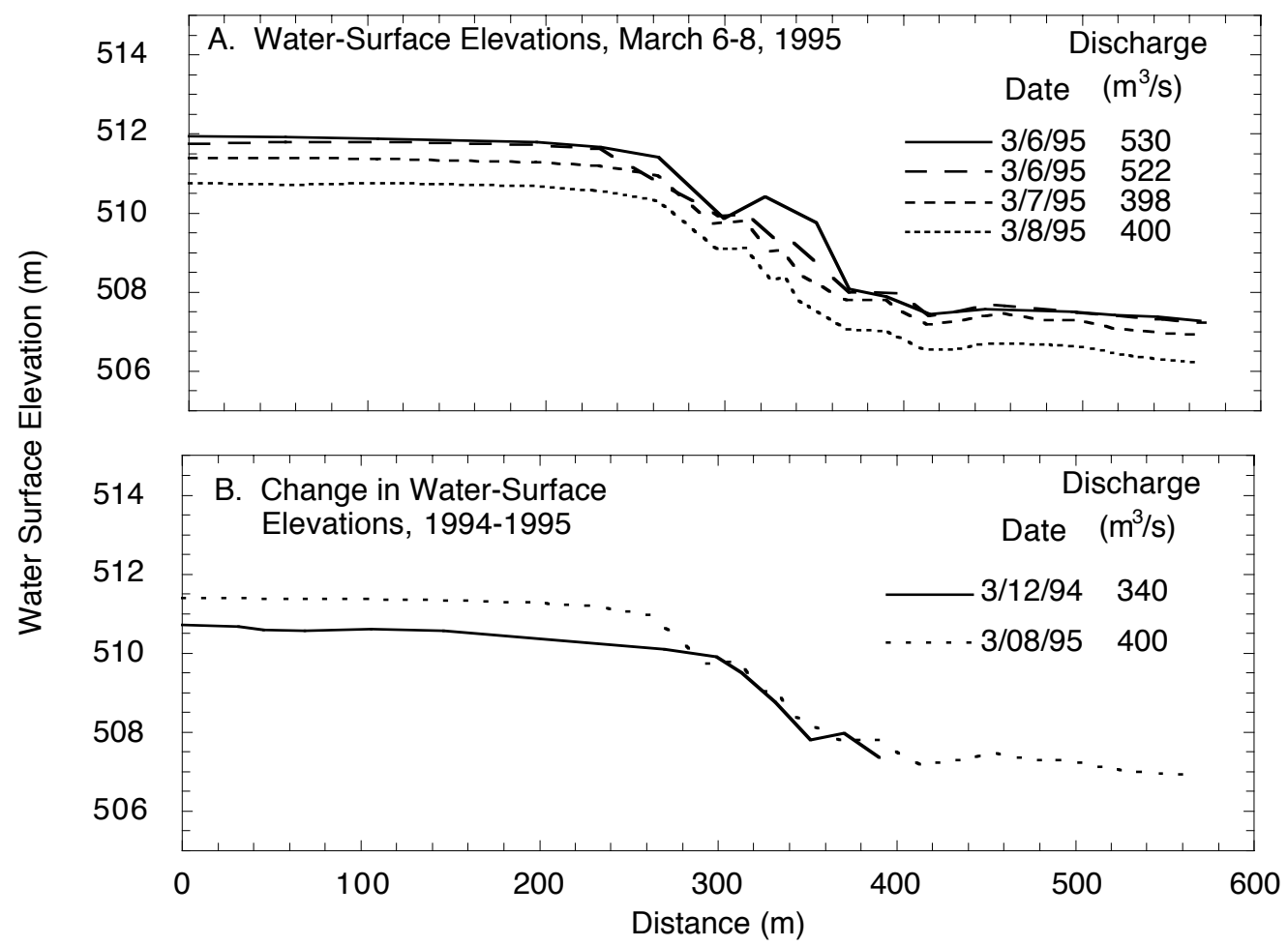

Figure 29. Longitudinal profile of the water-surface fall on the right side of Lava Falls Rapid. A. March 6-8, 1995. B. Comparison of water-surface profiles in March 1994 and March 1995.

the right side and the increase of more than $1 \mathrm{~m}$ in the stage-discharge relation at the head of the rapid. Flow velocity through the rapid, particularly in the Right Run (fig. 11b), had increased. At a discharge of $312 \mathrm{~m}^{3} / \mathrm{s}$, we measured an average surface velocity of $4.3 \mathrm{~m} / \mathrm{s}$ in the left run, whereas Kieffer (1988) reported velocities of $3.3 \mathrm{~m} / \mathrm{s}$ at a similar discharge. The Ledge Hole, which had a new rock lodged on its left edge, had a different shape, a sharper drop, and a stronger wave than before. The right lateral of the $\mathrm{V}$ Wave was much stronger than the left lateral. The Big Wave initially was very large but disappeared by the end of the day. A large, continuously breaking wave rolled off of the Black Rock, and large whirlpools formed to the right of and behind the Black Rock. Cobbles and boulders were heard rolling along the bottom above the sound of the rapid.

Downstream from Lava Falls Rapid, eddies on both sides of the river were replaced by fast-moving water over a long and narrow debris bar (fig. 28b). The tail waves, which had previously veered to the left, now moved straight downstream (fig. 28). A secondary rapid temporarily formed adjacent to the Warm Springs (figs. 2, 3), but its 1-m waves subsided to about $0.25 \mathrm{~m}$ as the day progressed. We interpreted the secondary riffle as flow around and over a new debris bar where the pool used to be; the size of the riffle probably changed as a gravel/ cobble bar migrated downstream into Lower Lava Rapid. 


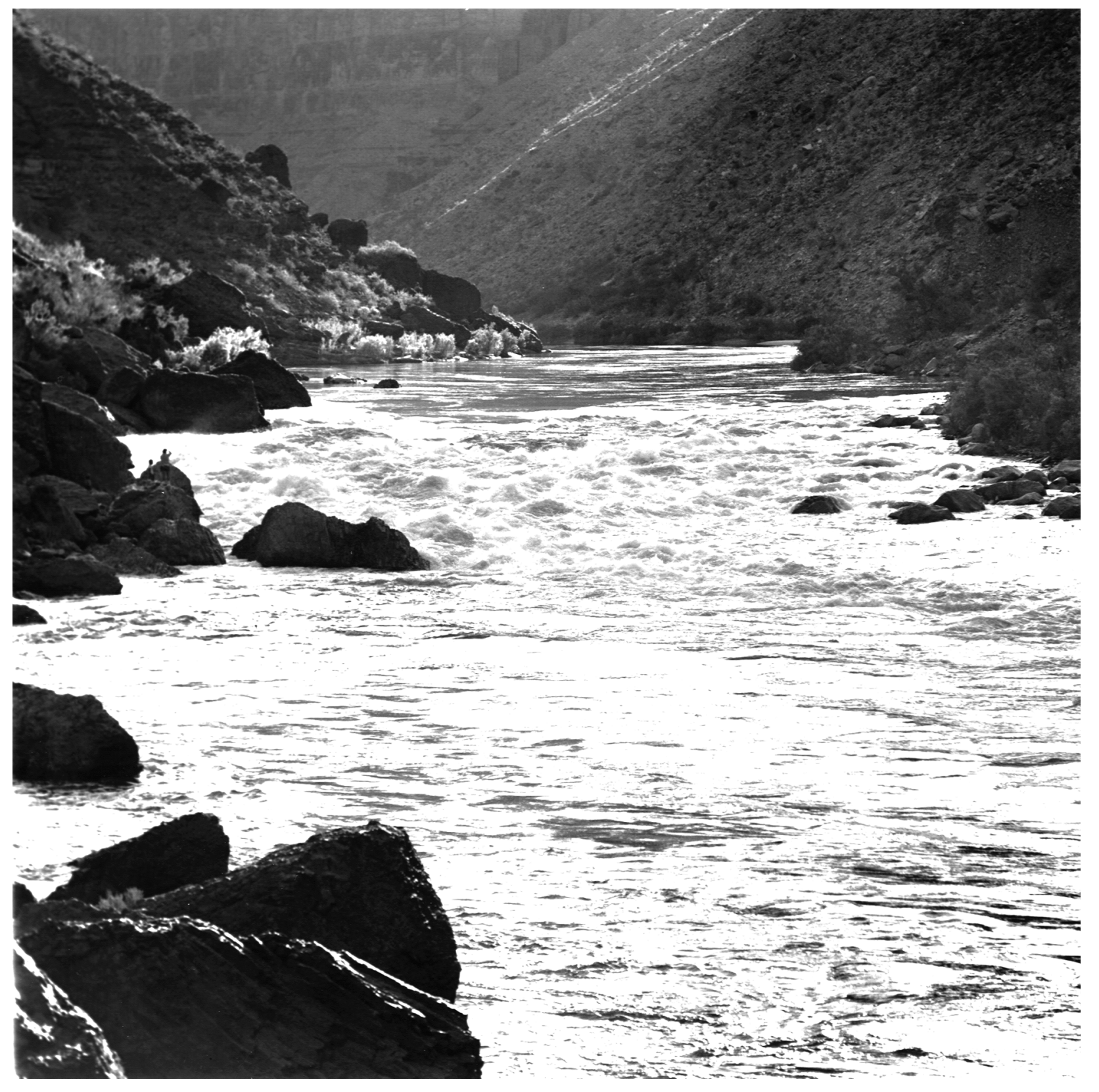

Figure 30. Upstream view of Lava Falls Rapid from the lower right (Stake 2962). A. (1973; M. Litton). At a discharge of about $370 \mathrm{~m} / \mathrm{s}$, Lava Falls appears to be continuous, frothy whitewater. For safety purposes, river runners commonly floated in the foreground eddy until all boats were through the rapid. Dense riparian vegetation grew next to river level on the debris fan at right. The Black Rock is prominent at left center. 


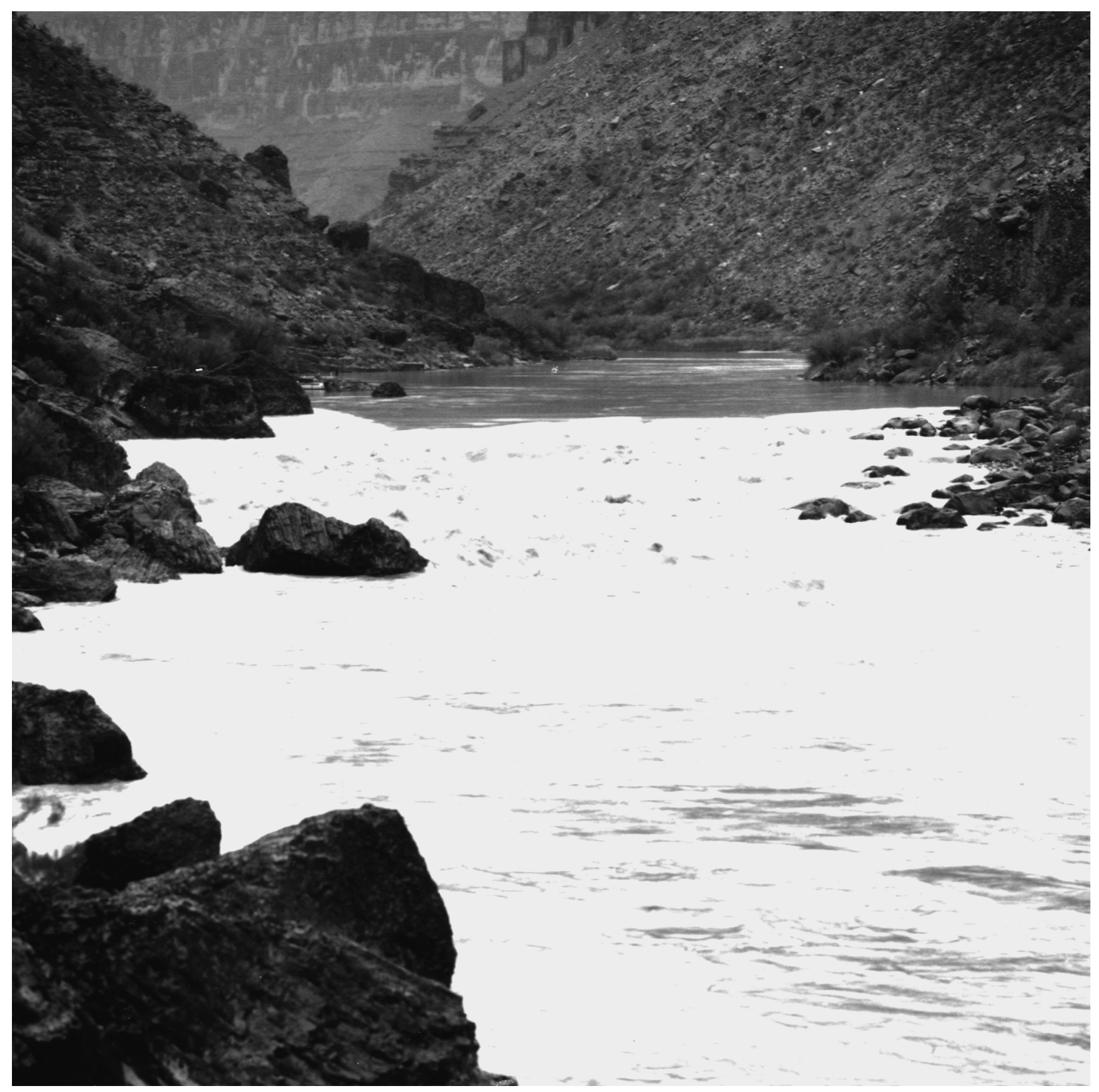

B. (March 5, 1995; S. Tharnstrom). More rocks were exposed on the debris fan in this view, which shows about 310 $\mathrm{m}^{3} / \mathrm{s}$ in the rapid. There is no change between 1972 and 1995 except that riparian vegetation was scoured away during Colorado River floods in 1983 and 1993.

Figure 30. Continued. 


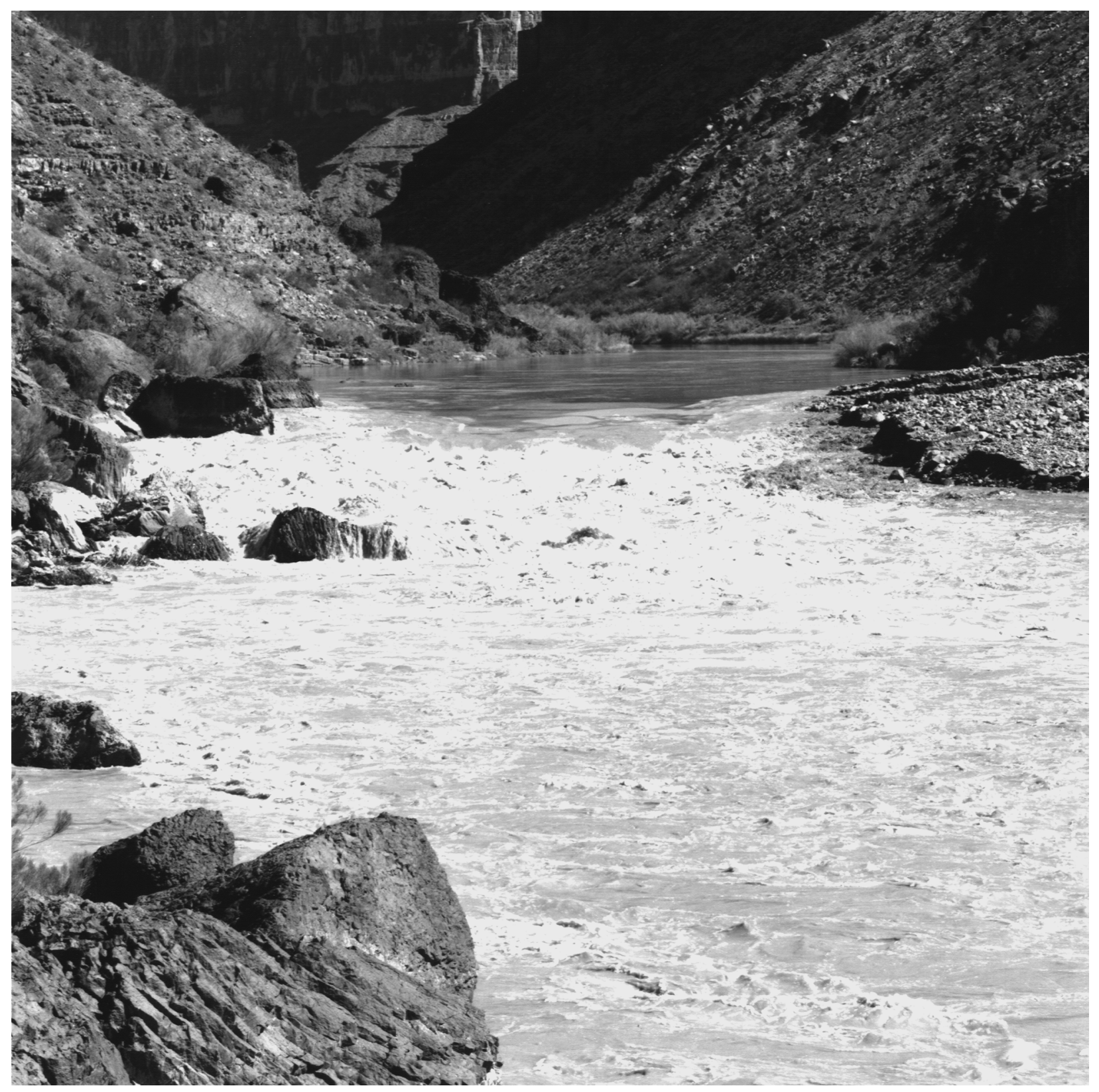

C. (March 6, 1995; S. Tharnstrom). The 1995 debris flow occurred about 11 hrs before this photograph was taken. A small flood of $500 \mathrm{~m}^{3} / \mathrm{s}$ in the Colorado River, combined with $14-28 \mathrm{~m}^{3} / \mathrm{s}$ of recessional flow in Prospect Canyon, reworked the distal edge of the debris fan. Water pours over the Black Rock, where it previously had not until discharges greater than $700 \mathrm{~m}^{3} / \mathrm{s}$. Fast water replaced the eddy in the foreground because reworked cobbles and gravel filled the pool downstream from the rapid.

Figure 30. Continued. 


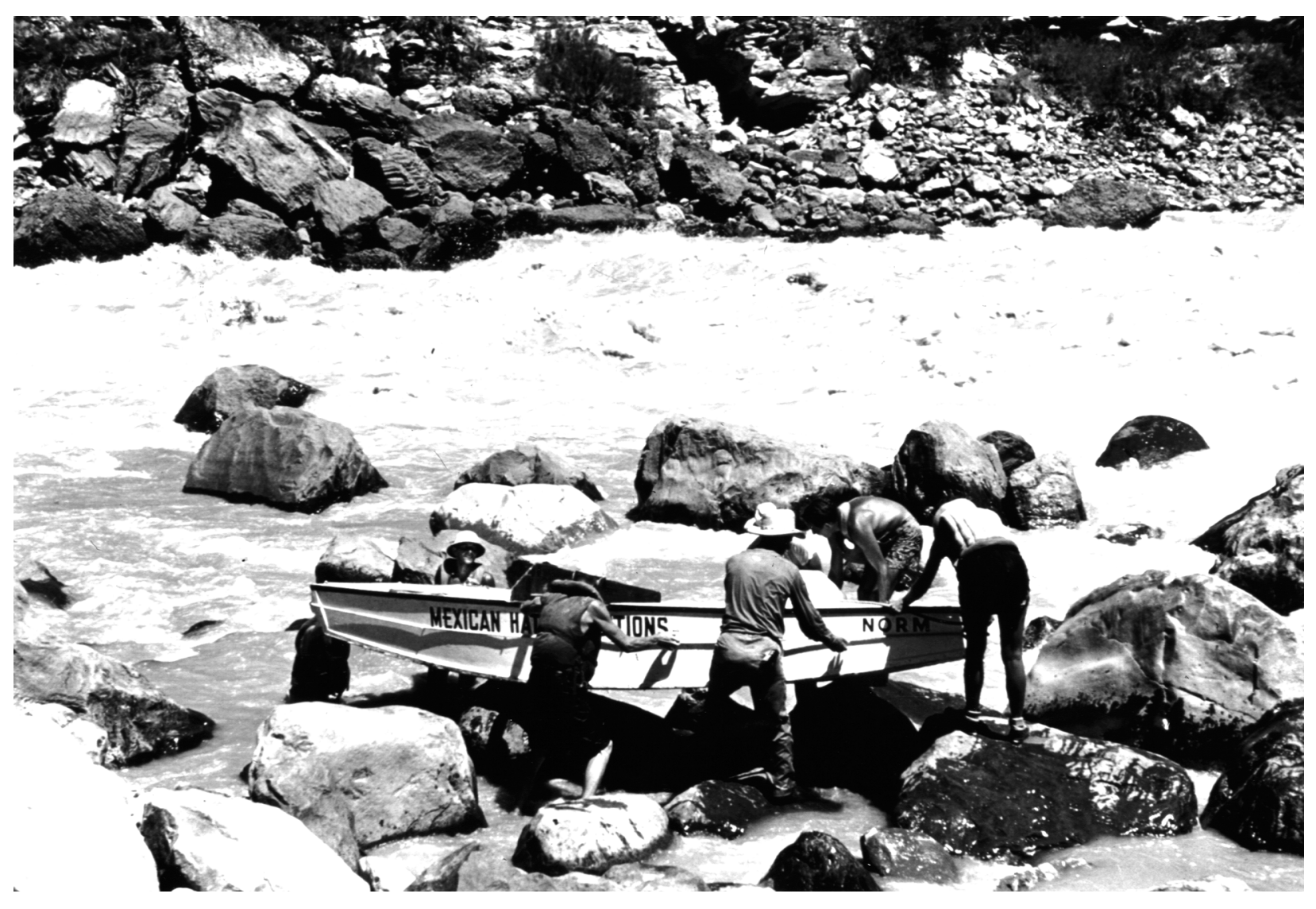

Figure 31. View across Lava Falls Rapid from river left (Stake 2969). A. (July 1952; T. Nichols). Before the advent of rubber rafts, most river trips portaged boats around Lava Falls Rapid. Here, Mexican Hat Expeditions trip paused during a portage with the boat completely out of the water on large boulders deposited in 1939. 


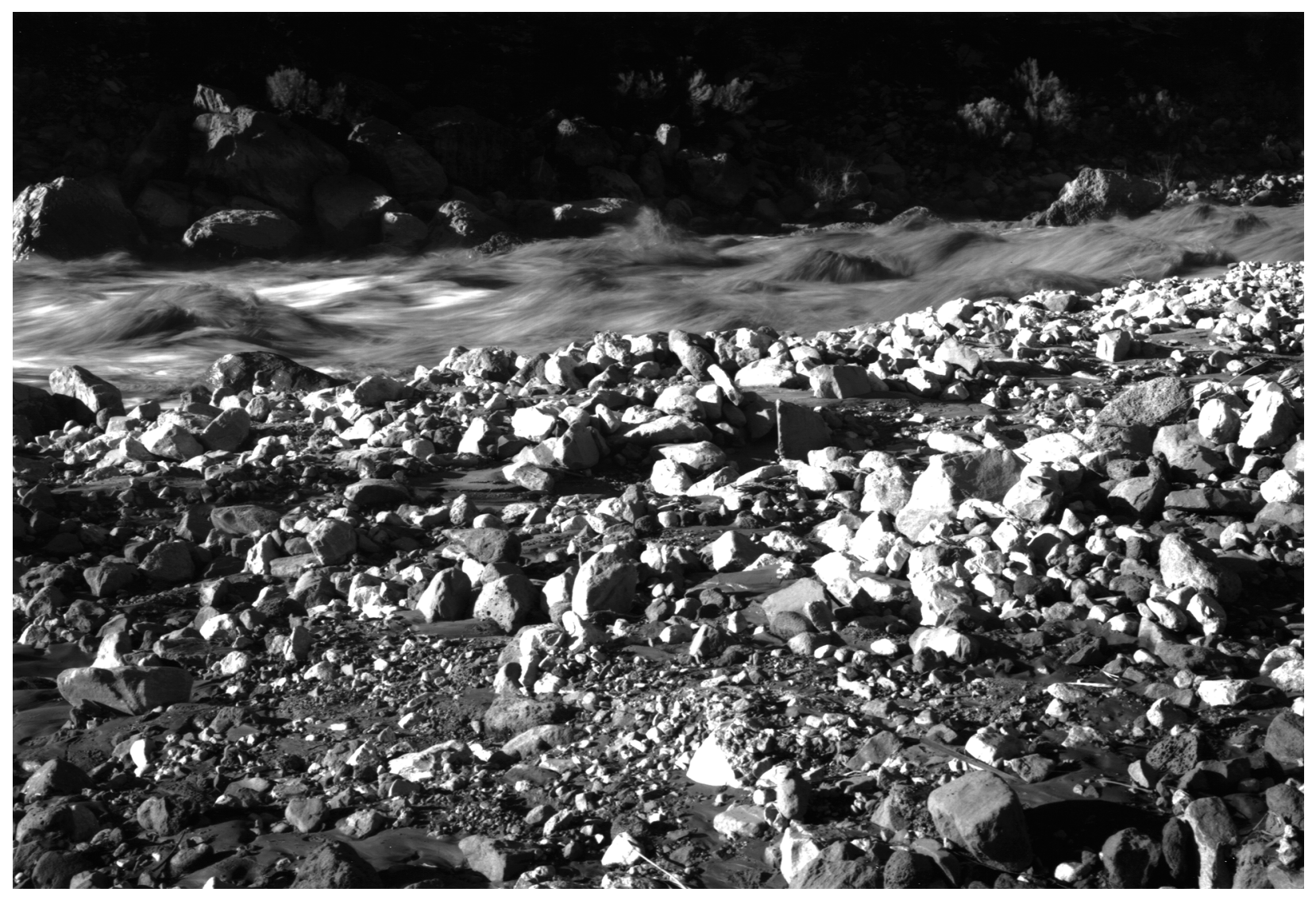

B. (March 7, 1995; D. Oldershaw). This match, which may be off by a meter or more, shows deposition by the 1995 debris flow. This view is probably similar to the view from the aggraded debris fans in 1955 and 1963 ; the 1954 and 1966 debris flows were considerably smaller. One of the boulders visible in the 1952 view is present at left center.

Figure 31. Continued. 
The rapid changed slowly after noon on March 6. By mid-afternoon, a run developed just to the left of the Ledge Hole. By March 8, the configuration of the rapid and its water-surface profile stabilized (fig. 29). At a discharge of $400 \mathrm{~m}^{3} / \mathrm{s}$, the constriction from the new debris fan caused the stage in the rapid to appear as if the discharge was $170 \mathrm{~m}^{3} / \mathrm{s}$ higher. The drop at the head of the rapid increased by $0.9 \mathrm{~m}$ from the 1994 water-surface profile for a roughly equivalent discharge (fig. $29 \mathrm{~b}$ ), although the stage remained similar through the rapid; in other words, the total drop through the main part of the rapid increased from $3.1 \mathrm{~m}$ in 1994 to $4.0 \mathrm{~m}$ in 1995 .

\section{INITIATION OF DEBRIS FLOWS IN PROSPECT CANYON}

Debris flows in Prospect Canyon are initiated under very specific conditions. Runoff generated in Prospect Valley must flow over the waterfall at the head of Prospect Canyon in sufficient quantity to erode and mobilize the colluvial wedges, channel deposits, and debris-flow deposits below. Although most Grand Canyon tributaries are small, and debris flows typically are initiated during intense summer thunderstorms, runoff in Prospect Valley is generated by the broad array of hydroclimatic conditions that affect other watercourses in the southwestern United States.

\section{Hydroclimatology}

Three general storm types are capable of causing debris flows in Grand Canyon (Melis and others, 1994). Intense rainfall from convective thunderstorms, which usually occur between June and October, commonly initiate debris flows; these storms are part of Arizona's summer monsoon (Hirschboeck, 1985). Dissipating tropical cyclones, which can cause intense and sustained precipitation in the southwestern United States between July and October (Hansen and Shwarz, 1981; Smith, 1986), have caused some of the most severe flooding in the region (Roeske and others, 1978; Aldridge and Eychaner, 1984; Roeske and others, 1989; Webb and Betancourt, 1992). Unusually warm winter storms, possibly combined with rainfall on existing snowpacks, also causes debris flows in Grand Canyon (Cooley and others, 1977).

Monsoonal conditions result from moist air entering the southwestern United States from the Gulf of Mexico and (or) the eastern North Pacific Ocean (Hansen and Shwarz, 1981). The interannual variability of monsoonal precipitation is weakly related to variability in global circulation patterns (Webb and Betancourt, 1992) and affects the number of storms with the potential to initiate debris flows in the canyon. Hereford and Webb (1992) documented a decline in warm-season (June-October) rainfall on the Colorado Plateau after about 1941. For eastern Grand Canyon, Hereford and others (1993) reported that the wettest period in the post-dam period (1963-1990 in their case) was 1978-1984.

Among the 529 tributaries of Grand Canyon, dissipating tropical cyclones are only known to have initiated debris flows in Prospect Canyon in only two years: 1939 and 1963. Most tropical cyclones form in the eastern North Pacific Ocean and travel northwestward along the coast of Mexico before dissipating over the ocean. The residual moisture from these storms is typically transported into Arizona with cutoff low-pressure and frontal systems entering Arizona from the northwest (Smith, 1986).

Warm winter storms initiated debris flows in Grand Canyon in 1966 and 1995. These storms, which typically occur from December through March, cause heavy rain and snow that mostly affects large drainage basins like Prospect Valley. Debris flows initiated by runoff from warm winter storms had relatively high discharges and flow volumes (Melis and others, 1994). These longduration storms affect large areas and may trigger multiple hillslope failures, leading to high-volume debris flows and sustained runoff such as the Crystal Creek debris flow of 1966 (Cooley and others, 1977; Webb and others, 1989). Winter rainfall in Grand Canyon has increased, particularly after the mid-1970s (fig. 32b).

The occurrence of debris flows in Prospect Canyon is only weakly related to regional storms. With the exception of the 1939 event, point rainfall records at stations near Prospect Canyon do not consistently show unusually high rainfall on the dates of debris flows, although for each date, one station may have recorded a relatively long 


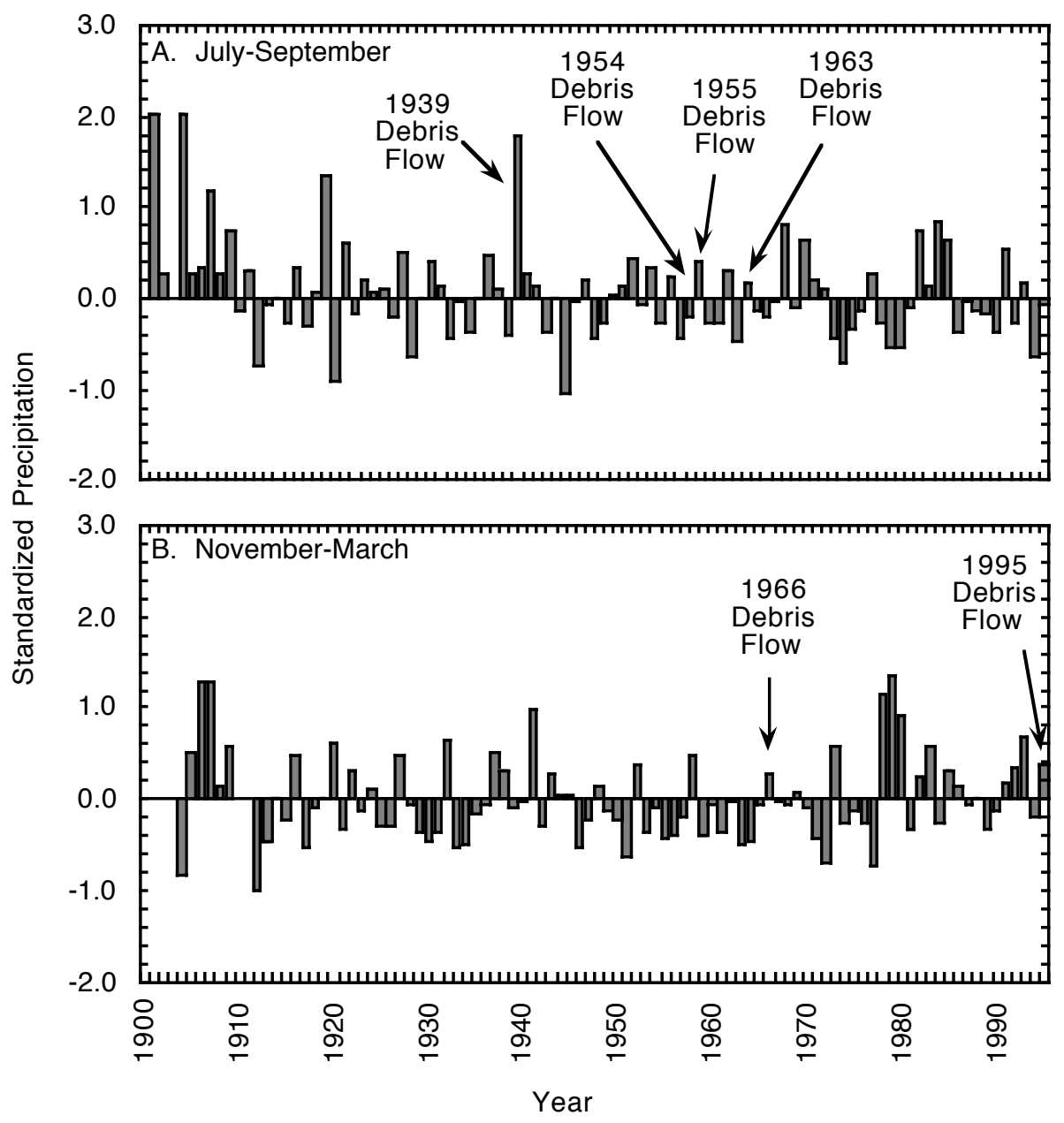

Figure 32. Standardized seasonal precipitation for eight stations in the vicinity of western Grand Canyon (appendix 2). Seasonal precipitation is converted to a time series with mean $=0$ and variance $=1$; positive values represent above average precipitation, whereas negative values are below-average precipitation. A. Summer (July-September) precipitation. B. Winter (November-March) precipitation.

recurrence-interval daily total or storm (appendix 3). For example, the 1955 debris flow appears to have been initiated during a storm at Mount Trumbull with a recurrence interval of 100 years, but rainfall was not unusual in other parts of the region. Most of the rainfall stations are at least 40 $\mathrm{km}$ from the Prospect Valley drainage basin (appendix 2), and rainfall recorded at these stations may not be representative of the storm conditions in the drainage basin.

Debris-flow initiation in Prospect Canyon is not related to the amount of seasonal precipitation. Although monthly precipitation was high when most of the debris flows occurred (fig. 33), seasonal precipitation was not consistently high. For example, the 1966 and 1995 debris flows occurred during the 24th and 18th wettest winters (November-March), respectively, in the 92-year record (fig. 32b). The 1939, 1954, 1955, and 1963 debris flows occurred during the $1 \mathrm{st}, 75 \mathrm{th}, 35 \mathrm{th}$, and 13th wettest summers (July-September), respectively (fig. 32a). Debris flows in Prospect Canyon may not require season-long buildup of antecedent soil moisture; above-average rainfall in the preceding month may be sufficient.

The size of storm cells that spawn intense precipitation may be too small to affect both the Prospect Valley drainage basin and surrounding rainfall stations. At Tuweep Ranger Station, $40 \mathrm{~km}$ from Prospect Canyon, the storm that caused the 1963 debris flow was relatively brief with a maximum hourly intensity of $4.5 \mathrm{~mm} / \mathrm{hr}$ (fig. 34a; 

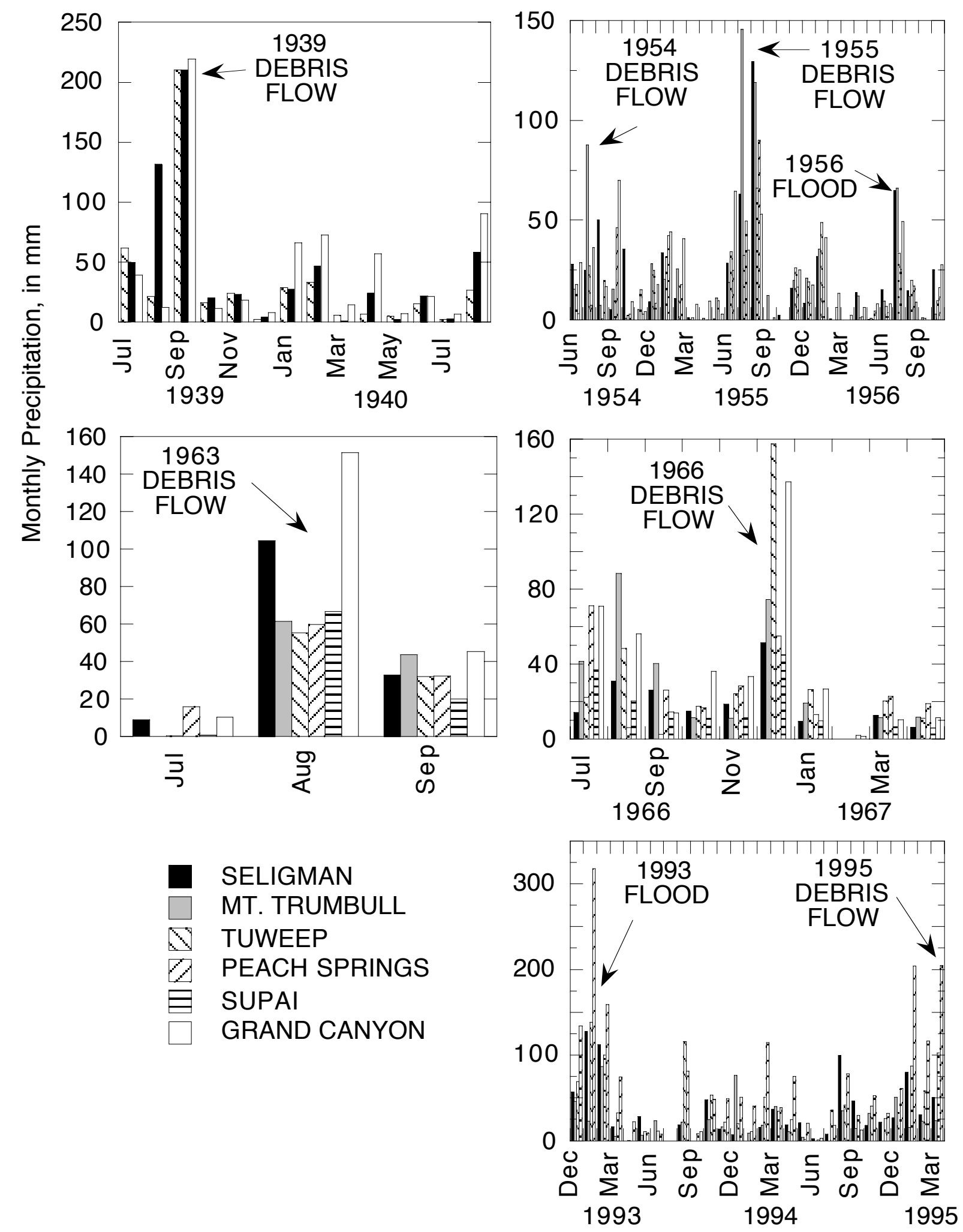

Figure 33. Monthly precipitation near the Prospect Valley drainage basin associated with Prospect Canyon debris flows and floods. A. July 1939 to August 1940. B. June 1954 to October 1956. C. July to September 1963. D. July 1966 to March 1967. E. December 1992 to March 1995. 

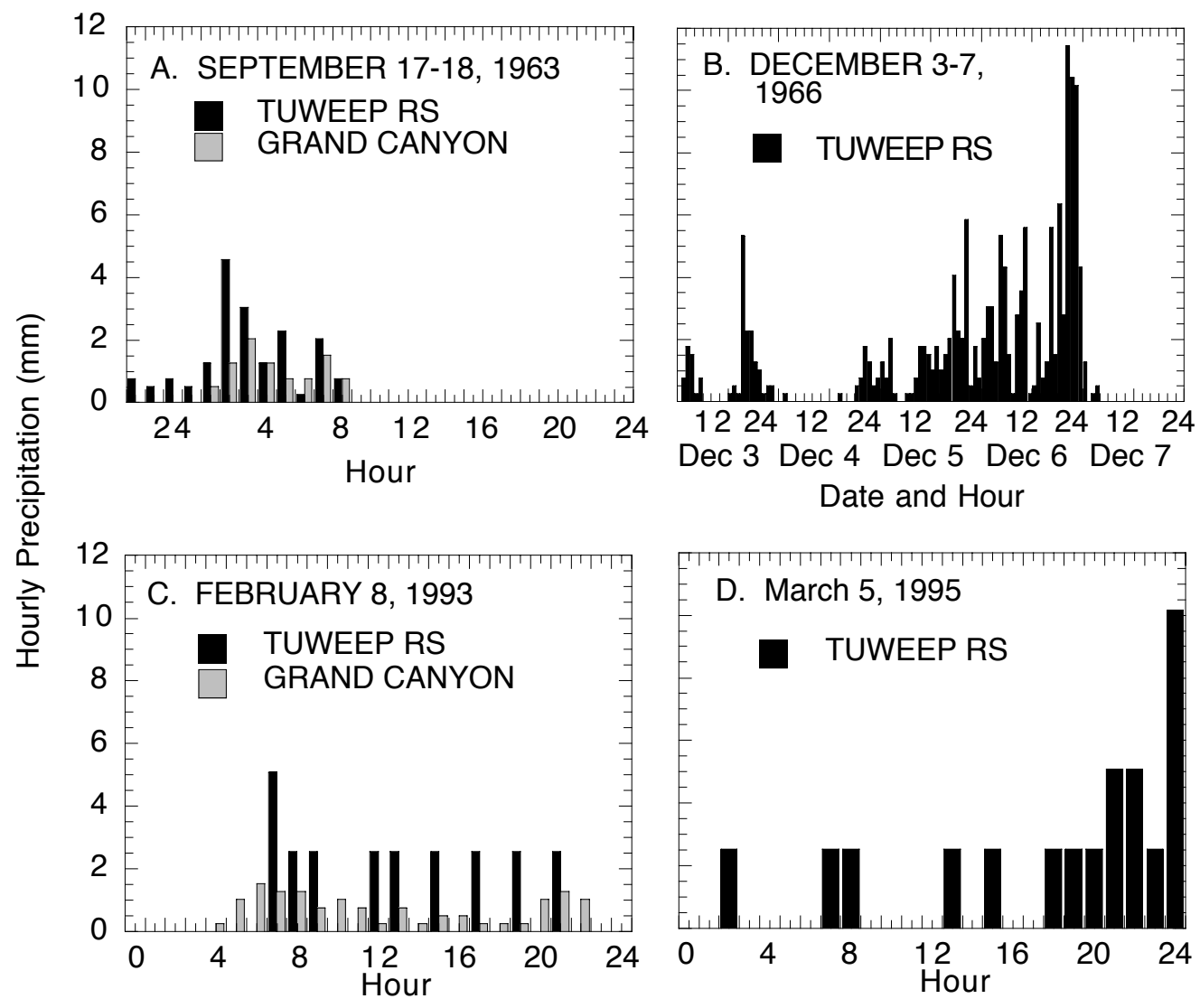

Figure 34. Hourly precipitation at Tuweep Ranger Station and Grand Canyon during three historic debris flows and one flood in Prospect Canyon. A. September 1963. B. December 1966. C. March 1995. D. February 1993.

U.S. Department of Commerce, 1963). During the debris flow of December 6, 1966, radar maps of cloud cover do not show unusually large storm cells in western Grand Canyon (Butler and Mundorff, 1970). Steady, gentle rain fell at Tuweep Ranger Station, followed by three hours of rainfall with intensities of $10-11 \mathrm{~mm} / \mathrm{hr}$ (U.S. Department of Commerce, 1966; fig. 34b). Radar maps (not shown) at the time of the 1995 debris flow also did not show unusual storm cells despite significant rainfall intensities of $11 \mathrm{~mm} / \mathrm{hr}$ (fig. 34d).

Storms that initiate debris flows are different in an important way from those that cause streamflow floods, particularly during winter. Both the 1966 and 1995 storms ended with notably high-intensity rainfall (fig. 34b and 34d). The runoff that initiated both the 1966 and 1995 debris flows likely came from microbursts of precipitation from clouds centered over the watershed. In contrast, the rainfall that caused the 1993 flood in Prospect Canyon had sustained but light intensities (fig. 34c). Bursts of rainfall at the end of the storm appear to be a requirement for debris-flow initiation.

\section{The Firehose Effect}

Because of the waterfall separating Prospect Valley and Prospect Canyon (fig. 3), the firehose effect is the primary process of debris-flow initiation in Prospect Canyon. This process involves the impact of a concentrated stream of water falling on unconsolidated colluvial wedges. The power generated by falling water in Prospect Canyon is extremely large; for example, a clearwater discharge of $100 \mathrm{~m}^{3} / \mathrm{s}$, a $10-\mathrm{yr}$ flood in 


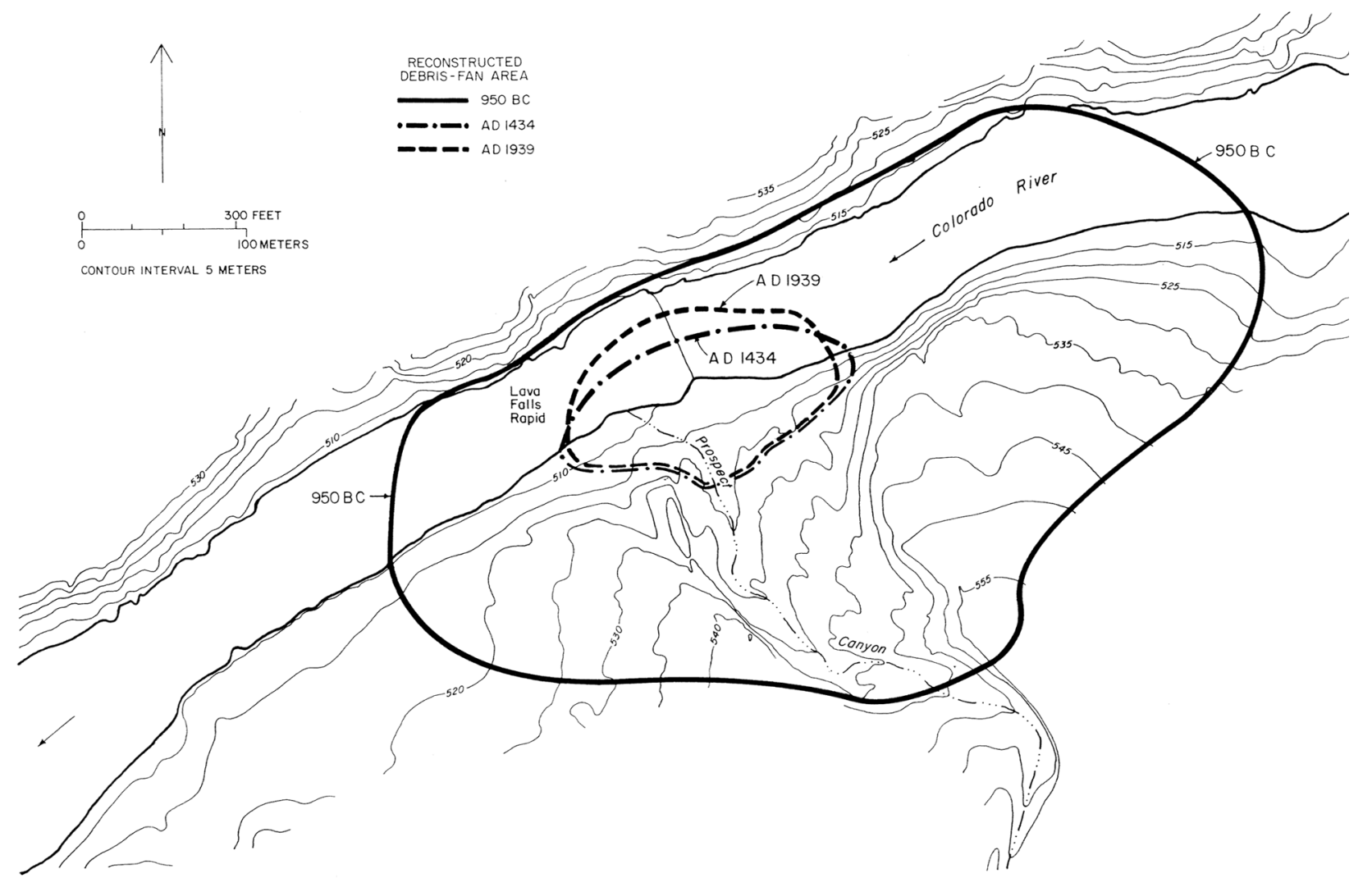

Figure 35. The spatial extent of debris fans deposited by Holocene debris flows from Prospect Canyon. The location of the edge and the thickness of the debris fan were determined by projection into the river from remnant deposits.

Prospect Valley, develops a terminal velocity of about $80 \mathrm{~m} / \mathrm{s}$ under the $325-\mathrm{m}$ waterfall (assuming an uninterrupted fall and negligible friction losses). This falling water has an impact power of approximately $80 \mathrm{Mw}$, which is more than sufficient to erode colluvial wedges and bedrock.

During the 1995 debris flow, streamflow poured over the waterfall, hitting high-angle colluvial wedges (shown in the center of fig. 27) and the channel of Prospect Canyon. The falling water eroded a 8-m deep, 20-m wide, and 15-m high cylindrical section of the colluvial wedge and a crater $13 \mathrm{~m}$ in diameter and $6 \mathrm{~m}$ deep in the bottom of Prospect Canyon. In addition, sediment was scoured to a depth of about $4 \mathrm{~m}$ from a $200-\mathrm{m}$ reach of the channel. The total volume removed from the impact areas and channel bed was 6,000 $\mathrm{m}^{3}$, or about 63 percent of the volume of sediment deposited on the debris fan.
The amount of sediment transported by the 1995 debris flow increased down Prospect Canyon when alluvial deposits, particularly channel banks, were undercut eroded. This "bulking-up" occurs when channel banks collapse during passage of the debris flow initiated under the waterfall. We assumed $\mathrm{g}=22,000 \mathrm{~N} / \mathrm{m}^{3}$ for a debris flow with a discharge of $500 \mathrm{~m}^{3} / \mathrm{s}\left(100 \mathrm{~m}^{3} / \mathrm{s}\right.$ of streamflow mobilized into a debris flow). Using an energy slope equal to the bed slope of 0.315 in Prospect Canyon and a channel-width range of $15-20 \mathrm{~m}$ yielded a range in stream power of $0.17-0.23 \cdot 10^{6}$ $\mathrm{W} / \mathrm{m}^{2}$. This value of stream power is more than an order of magnitude greater than the stream power reported for large streamflow floods (Costa and O'Connor, 1995) because our calculation is for a debris flow on a steep slope. However, the duration of debris flows is short $(\Delta \mathrm{t} \approx 1-3 \mathrm{~min}$ ) and the total energy expended is relatively small. 
Table 5. Peak discharge estimates from superelevation evidence for the debris flows of 1939, 1955, and 1963 in Prospect Canyon at cross section A - A'

\begin{tabular}{ccccccc}
\hline Year of flow & $\mathbf{R}_{\mathbf{c}}(\mathbf{m})$ & $\Delta \mathbf{H}_{\mathbf{r}}(\mathbf{m})$ & $\mathbf{W}(\mathbf{m})$ & $\begin{array}{c}\text { Velocity } \\
(\mathbf{m} / \mathbf{s})\end{array}$ & $\begin{array}{c}\text { Area } \\
\left(\mathbf{m}^{2}\right)\end{array}$ & $\begin{array}{c}\text { Discharge } \\
\left(\mathbf{m}^{\mathbf{3}} / \mathbf{s}\right)\end{array}$ \\
\hline 1939 & 50 & 3.0 & 40 & 6.1 & 170 & 1,000 \\
1955 & 50 & 0.7 & 20 & 4.1 & 70 & 290 \\
1963 & 50 & 1.5 & 20 & 6.1 & 60 & 370 \\
\hline
\end{tabular}

Although other studies have suggested streamflow can bulk-up into debris flow by failure of channel banks alone (Johnson and Rodine, 1984), there is no evidence of a debris flow in Grand Canyon that was initiated solely by streamflow undercutting channel banks (Melis and others, 1994). However, debris flows initiated below the waterfall at the head of Prospect Canyon entrain considerable amounts of additional sediment through erosion of colluvial wedges, channel banks, and bed sediments between the waterfall and the Colorado River. The only sediment exposed in the channel that was not moved were boulders greater than 2-3 $\mathrm{m}$ in diameter.

\section{MAGNITUDE AND FREQUENCY OF DEBRIS FLOWS}

\section{Discharge estimates}

We identified superelevated debris-flow deposits for the 1939, 1955, and 1963 events in upstream from section A - A' on the Prospect Canyon debris fan (Plate I). With the exception of the 1939 debris flow, we only found depositional evidence to constrain the cross-sectional area at the point of maximum superelevation. The site on the Prospect Canyon debris fan was a poor one for estimating discharge of debris flows. In the righthand bend just upstream from cross section A - A', a continuous line of boulders, combined with photographic evidence, provided the elevations of the flow surface on the inside and outside of the bend. No bedrock is exposed in the alluvial channel, which has changed in cross section (fig. 6) despite the presence of large boulders that were not moved by recent debris flows, particularly the 1995 event. The channel slope through the bend is 0.093 .

Using the depositional evidence and cross sections, we estimated discharges for the 3 debris flows (table 5). The 1939 debris flow had a discharge of about $1,000 \mathrm{~m}^{3} / \mathrm{s}$; this discharge is larger than the 1966 debris flow in Crystal Creek $\left(280 \mathrm{~m}^{3} / \mathrm{s}\right.$; Webb and others, 1989), which previously was considered the largest historic debris flow. The 1955 and 1963 debris flows were of a similar discharge of about $300-400 \mathrm{~m}^{3} / \mathrm{s}$. No depositional evidence remains of the 1954 and 1966 debris flows, and we could not estimate a peak discharge for the 1995 debris flow because it did not overtop channel banks to leave depositional evidence. Recessive streamflow after the 1995 debris flow obliterated any mudlines that might have been deposited during the peak discharge of the debris flow.

To provide another perspective on magnitude and frequency, we determined an approximate water content of 7-14 percent for Prospect Canyon debris flows using reconstitution techniques on less than less than $16 \mathrm{~mm}$ samples. Because this size fraction is about 20 percent of the total particle-size distribution (fig. 4a), the actual water content may have been less than 5 percent. As stated in the Methods section, the estimated 100-year streamflow flood in Prospect Valley is $800 \mathrm{~m}^{3} / \mathrm{s}$. Assuming this flood would produce a debris flows in Prospect Canyon with no attenuation of flow, and assuming the flood water constitutes 5 percent of the debris-flow volume, the 100-year debris flow could be as large as $16,000 \mathrm{~m}^{3} / \mathrm{s}$. This number appears to be unrealistically high and suggests that the regression equations for flood frequency may be inappropriate for the Prospect Valley drainage basin. 
Table 6. Characteristics of debris fans deposited at the mouth of Prospect Canyon between 1939 and 1995

\begin{tabular}{|c|c|c|c|c|c|c|}
\hline $\begin{array}{l}\text { Year of flood } \\
\text { (type) }\end{array}$ & $\begin{array}{c}\text { Maximum } \\
\text { debris-fan area } \\
\text { (ha) }\end{array}$ & $\begin{array}{c}\text { Maximum } \\
\text { debris-fan } \\
\text { thickness }(\mathrm{m})\end{array}$ & $\begin{array}{c}\text { Minimum } \\
\text { debris-fan } \\
\text { thickness }(m)\end{array}$ & $\begin{array}{c}\text { Range in } \\
\text { debris-fan volume } \\
\left(10^{3} \mathrm{~m}^{3}\right)\end{array}$ & $\begin{array}{c}\text { Constriction } \\
\text { ratio }\end{array}$ & $\begin{array}{c}\text { Maximum } \\
\text { constriction } \\
(\%)\end{array}$ \\
\hline $\begin{array}{c}950 \mathrm{BC}^{*} \\
(\mathrm{DF})\end{array}$ & 15.9 & 22 & 22 & 3,500 & 0.00 & 100 \\
\hline $\begin{array}{l}\text { AD } 1434^{*} \\
(\mathrm{DF})\end{array}$ & 1.07 & 5.0 & 4.0 & $43-54$ & 0.50 & 45 \\
\hline $\begin{array}{c}1939 * \\
(\mathrm{DF})\end{array}$ & 1.25 & 5.0 & 3.5 & $44-63$ & 0.20 & 80 \\
\hline $\begin{array}{l}1954 \dagger \\
(\mathrm{DF})\end{array}$ & 0.42 & 2.0 & 1.6 & $3.2-8.4$ & 0.55 & 40 \\
\hline $\begin{array}{l}1955 \dagger \\
(\mathrm{DF})\end{array}$ & 0.73 & 2.9 & 2.1 & $15-21$ & 0.30 & 70 \\
\hline $\begin{array}{c}1956 \dagger \\
(\mathrm{F})\end{array}$ & 0.24 & 0.8 & 0.5 & $1.2-1.9$ & na & na \\
\hline $\begin{array}{l}1963 \dagger \\
(\mathrm{DF})\end{array}$ & 0.73 & 1.9 & 1.7 & $12-14$ & 0.40 & 60 \\
\hline $\begin{array}{c}1966 \S \\
(\mathrm{DF})\end{array}$ & 0.38 & 1.6 & 1.0 & $3.8-6.1$ & 0.60 & 35 \\
\hline $\begin{array}{l}1995 \# \\
(\mathrm{DF})\end{array}$ & 0.56 & 1.7 & 1.7 & 9.4 & 0.40 & 60 \\
\hline
\end{tabular}

Notes: F -- streamflow flood, DF -- debris flow, nd -- no data, na -- not applicable. All areas and volumes are for sediments exposed above a discharge of $140 \mathrm{~m}^{3} / \mathrm{s}$. Maximum thickness were estimated during field surveys of non-eroded debris flow deposits; minimum thickness are the thickness of debris-flow deposit that would cover immobile boulders at mouth of Prospect Creek. The constriction ratio is the river-channel width divided by the average river channel width immediately upstream of the rapid (Kieffer, 1985, 1987); small constriction ratios indicate a highly constricted river. The maximum constriction is the percent reduction in river width, compared with an average of upstream and downstream widths, at the narrowest part of the rapid.

*Areas, volumes, and constriction ratios were determined by projection of the slopes of remnant deposits (Plate I) into the Colorado River. $\dagger$ Areas, volumes, and constriction ratios were determined by rectification of aerial photography (figs. 21, 24) using image processing software. $\S$ Areas, volumes, and constriction ratios were determined by rectification of oblique ground photography (e.g., fig. 12) using image processing software.

\section{Volumes of debris fans}

The entire Prospect Canyon debris fan above the $140 \mathrm{~m}^{3} / \mathrm{s}$ stage of the Colorado River has a total volume of $1.9 \cdot 10^{6} \mathrm{~m}^{3}$. To estimate the uneroded volume of surface tfa ( $950 \mathrm{BC})$, the highest surface on the Prospect Canyon debris fan (Plate I), we added the volume of the entrenched channel and the volume of the projected debris fan surface across the Colorado River. The reconstructed debris fan from surface tfa had an area of 16 ha and a volume of $3.5 \cdot 10^{6} \mathrm{~m}^{3}$ (table 6 ).

The projected height indicates that the debris flow crossed the Colorado River (fig. 35). The height above the center of the river at a stage of 140 $\mathrm{m}^{3} / \mathrm{s}$ is $19.3 \mathrm{~m}$ (point $\mathrm{V}$ ), $16.9 \mathrm{~m}$ (point $\mathrm{U}$ ), and 15.0 $\mathrm{m}$ (point T)(Plate I). Kieffer (1988) reported depths of the Colorado River at these points; therefore, the maximum thickness of the deposit above the bed of the Colorado River is $30.3 \mathrm{~m}$ (point V), $27.7 \mathrm{~m}$ (point $\mathrm{U}$ ), and $24.2 \mathrm{~m}$ (point $\mathrm{T}$ ).

Kieffer (1988) attributes the large basalt boulders on the right side of Lava Falls Rapid - for example, the Black Rock, the Entrance Rock, and the Scout Rock (fig. 11b) - to rockfall from the basalt cliffs above the rapid. This accumulation of boulders is unusual for the reach of channel above and below the rapid, where relatively few large basalt boulders appear under similar cliffs (see Kieffer, 1988). An alternative explanation is that these boulders were deposited by a debris flow (or debris flows) that dammed the Colorado River, such as the $950 \mathrm{BC}$ event that formed surface tfa. The projected area of the reconstructed tfa surface 


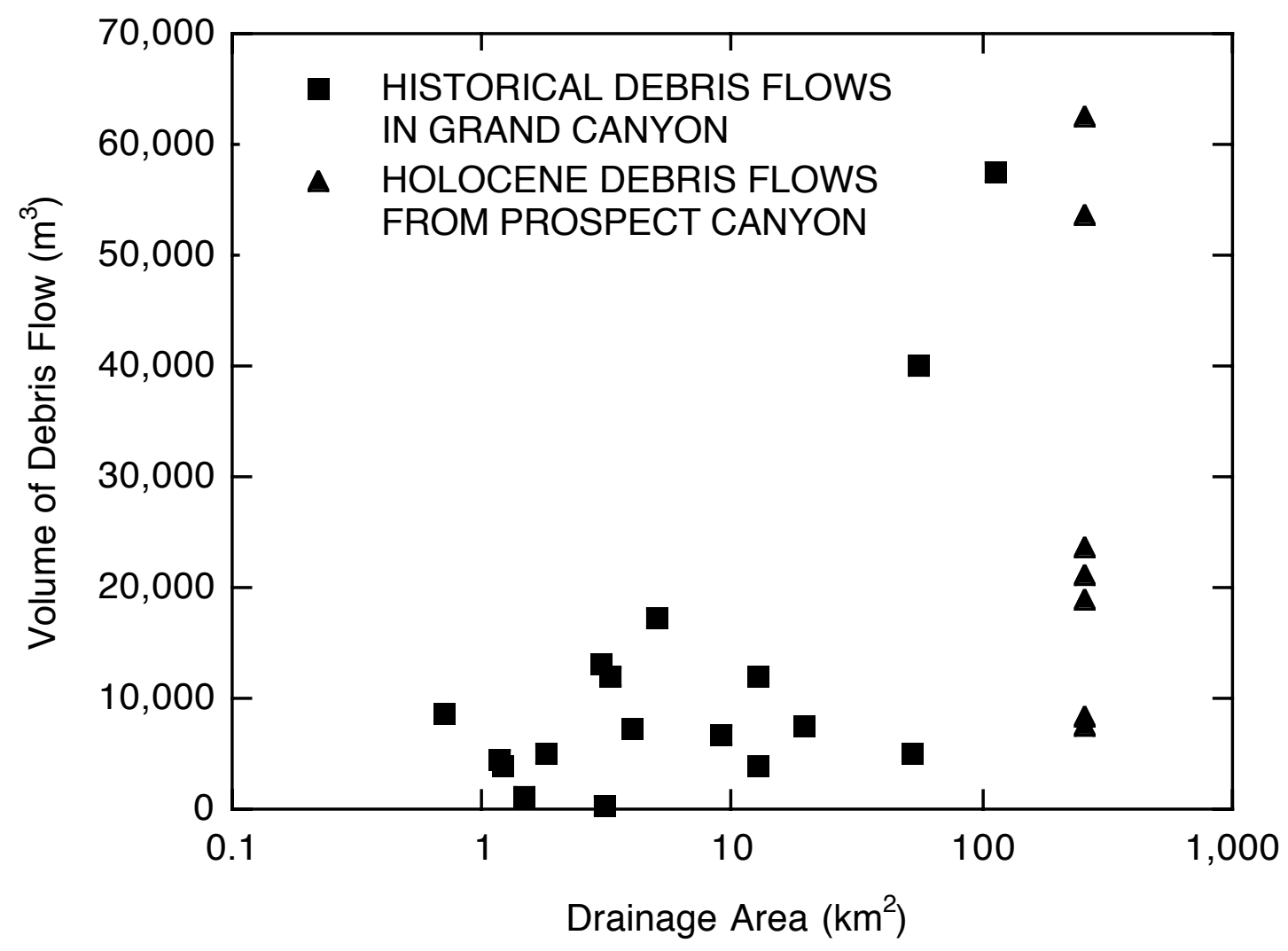

Figure 36. The volume of sediments deposited on debris fans by historical debris flows in Grand Canyon (modified from Melis and others, 1994) and Holocene debris flows from Prospect Canyon.

covers most of the large boulders, including the Black Rock by $1-2 \mathrm{~m}$ and the Entrance Rock by 5 $\mathrm{m}$, and is at about the same elevation as the Scout Rock. Similar-sized boulders remain in the channel of Prospect Canyon (appendix 4), supporting the possibility of Prospect Canyon as the source for boulders on the right side of the rapid.

Other Holocene and historic debris flows may not have been large enough to cross the Colorado River. Of the other fan-forming and inset Holocene deposits, we estimated a volume only for surface tif (AD 1434). The remaining deposits have a relatively steep surface slope, and projection into the river results in only a moderate-size debris fan (fig. 35). The 1939 debris flow, the largest historic event, deposited a debris fan of 1.25 ha and a volume of 44,000 - 63,000 $\mathrm{m}^{3}$ (table 6); in comparison, the uneroded fan of the 1966 Crystal Creek debris flow is about $58,000 \mathrm{~m}^{3}$ (Melis and others, 1994), or about the same size. The 1965 debris fan at Warm Springs Rapid on the Yampa was $40,000 \mathrm{~m}^{3}$ (Hammack, 1994), or slightly smaller than the Grand Canyon debris fans. Other Prospect Canyon debris flows deposited 3,000 $21,000 \mathrm{~m}^{3}$ of sediment on the debris fan. The depositional volumes of debris flows from Prospect Canyon are comparable to the volumes of debris flows from other tributaries in Grand Canyon, although the range in volume is large, probably because the Prospect Valley drainage basin is the largest tributary from which debris flows have been observed (fig. 36).

\section{Constrictions of the Colorado River}

Holocene debris flows from Prospect Canyon deposited debris fans with $\mathrm{C}_{\mathrm{w}}$ that range from 30100 percent and the maximum $C_{\mathrm{w}}$ from $35-100$ percent $\left(0.00<\mathrm{C}_{\mathrm{r}}<0.61\right)$ (table 7$)$. In 1872, the average $C_{w}$ (at $280 \mathrm{~m}^{3} / \mathrm{s}$, reconstructed by rectifying fig. 12a) was 5 percent $\left(C_{r}=0.75\right)$, and $C_{r}$ in 1994 at $230 \mathrm{~m}^{3} / \mathrm{s}$ (fig. 28a) was 30 percent $\left(\mathrm{C}_{\mathrm{r}}=\right.$ $0.60)$. Therefore, historic debris flows decreased 

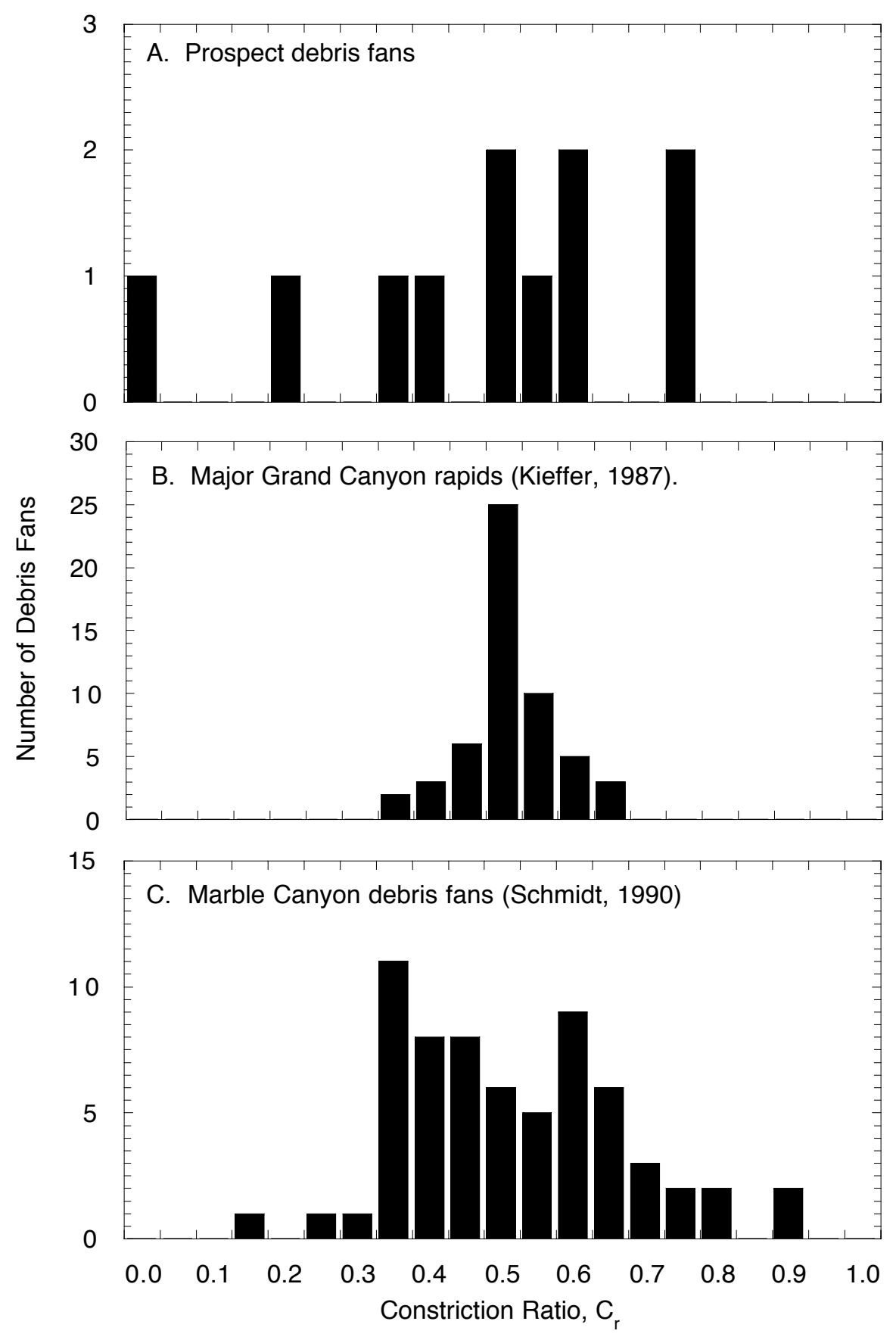

Figure 37. Constriction ratios of debris fans in Grand Canyon. A. Prospect Canyon debris fans aggraded by Holocene debris flows and reworked by the Colorado River (table 7). B. Major Grand Canyon rapids (Kieffer, 1987). C. Debris fans in Marble Canyon (Schmidt, 1990). 


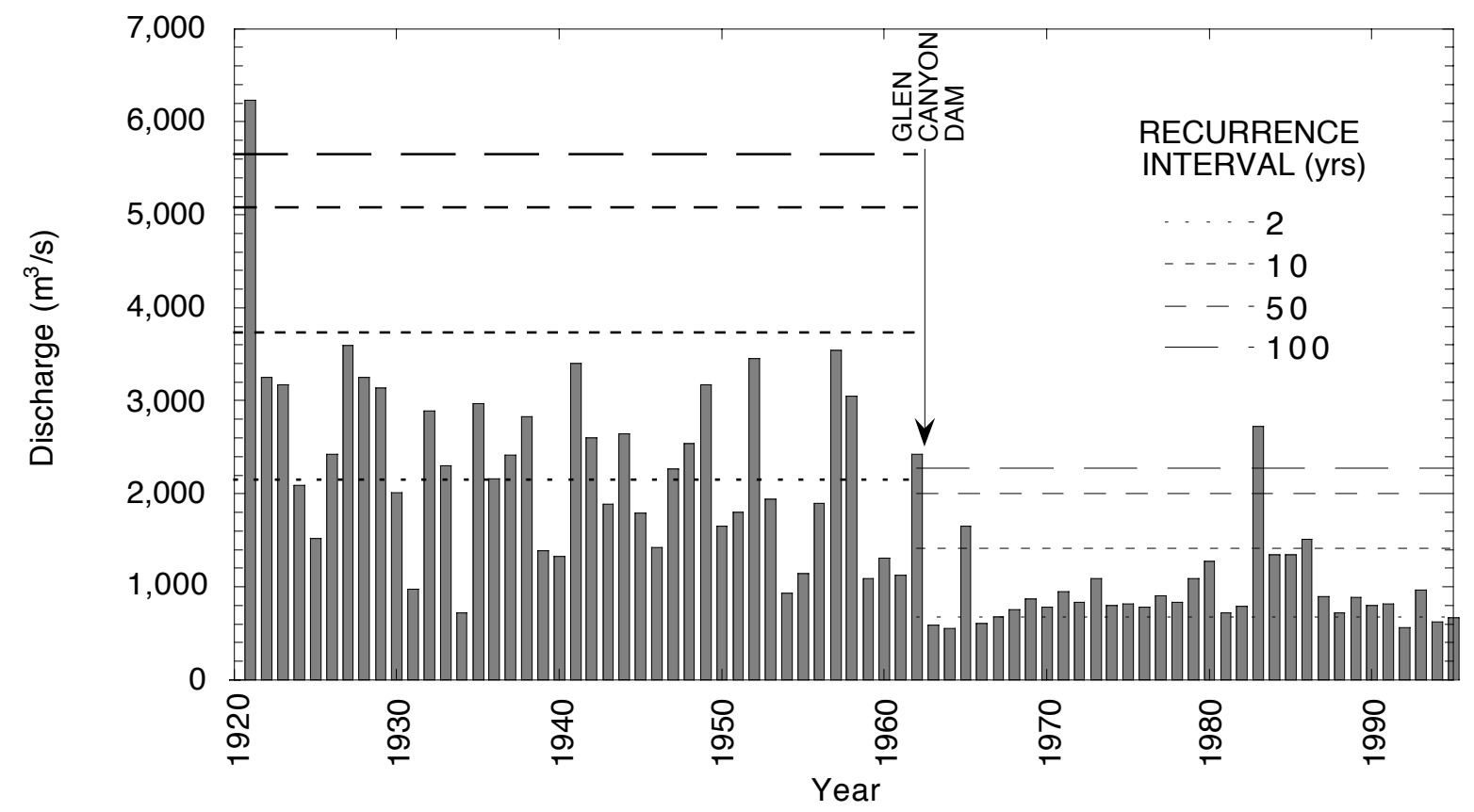

Figure 38. Annual series of instantaneous peak discharges for the Colorado River near Grand Canyon, Arizona. Recurrence intervals were calculated using a log-Pearson type III distribution for pre-dam (1921-1963) and post-dam (1963-1995) discharges.

the width of Lava Falls Rapid by about 25 percent before the 1995 debris flow.

Values of $\mathrm{C}_{\mathrm{r}}$ for Holocene debris flows at Lava Falls Rapid span most of the previously reported range of $\mathrm{C}_{\mathrm{r}}$ in Grand Canyon (fig. 37). Kieffer (1987) reported an average $C_{r}$ of 0.50 for major Grand Canyon rapids. Similarly, the average $\mathrm{C}_{\mathrm{r}}$ from Schmidt (1990), calculated from his expansion data, is 0.54 . Rapids affected by debris flows, like Lava Falls, can have a wide range of constrictions over periods of a century, rendering the average value of $\mathrm{C}_{\mathrm{r}}$ not very useful as an overall measure of the stability of rapids.

In her discussion of constriction ratios, Kieffer $(1985,1987)$ noted that Crystal Rapid likely had a maximum $\mathrm{C}_{\mathrm{r}}$ of about 0.25 before reworking. This ratio exceeds the $C_{r}$ for the 1939 debris flow from Prospect Canyon (table 7), which indicates that the 1939 debris flow from Prospect Canyon had a greater effect on the Colorado River.

\section{Frequency of debris flows}

The evidence of Holocene debris flows is sufficient to estimate recurrence intervals for this type of flash flood in Prospect Canyon. Throughout Grand Canyon, debris flows have an average recurrence interval of one debris flow every 20-50 yrs (Melis and others, 1994). In a history spanning 123 years, Prospect Canyon has had six debris flows (table 4); if these were considered independent of one another, the historical frequency of debris flows is one every 20 years. Debris flows from Prospect Canyon are clustered in time: most occurred during the middle part of the 20th century, when five debris flows occurred in a 27 -year period (one every 5 years). Alternatively, six debris flows occurred from 1939 through 1995 for a recurrence interval of about one every 10 years. Regardless of the estimation period, the frequency of historic debris flows from Prospect Canyon (one every 5-20 years) is greater than the 
Table 7. Constriction percentage and constriction ratios of historic aggraded and reworked debris fans at the mouth of Prospect Canyon

\begin{tabular}{|c|c|c|c|c|c|}
\hline Year & $\begin{array}{l}\text { Date of photograph } \\
\text { or survey }\end{array}$ & $\begin{array}{l}\text { Discharge on } \\
\text { date }\left(\mathrm{m}^{3} / \mathrm{s}\right)\end{array}$ & $\begin{array}{l}\text { Maximum discharge } \\
\text { between dates }\left(\mathrm{m}^{3} / \mathrm{s}\right)\end{array}$ & $\begin{array}{l}\text { Constriction } \\
\text { ratio, } C_{r}\end{array}$ & $\begin{array}{c}\text { Constriction } \\
\text { percentage } C_{w}(\%) \text {, }\end{array}$ \\
\hline 1872 & Apr 16 & 280 & na & $0.75 *$ & $5 *$ \\
\hline 1939 & Sep 6 & 150 & 8,500 & $0.20 \dagger$ & $80 \dagger$ \\
\hline 1955 & Jul 24 & 250 & 3,460 & $0.55 \S$ & $40 \S$ \\
\hline 1955 & Mar 19 & 540 & 530 & $0.65 \S$ & $30 \S$ \\
\hline 1955 & Mar 21 & 400 & 540 & $0.65 \S$ & $30 \S$ \\
\hline 1956 & Mar 25 & 180 & 1,140 & $0.30 \S$ & $70 \S$ \\
\hline 1956 & Apr 16 & 300 & 520 & $0.35 \S$ & $60 \S$ \\
\hline 1956 & Aug 29 & 80 & 1,900 & $0.30 \S$ & $70 \S$ \\
\hline 1957 & May 4 & 520 & 680 & $0.60 \S$ & $35 \S$ \\
\hline 1958 & Apr 20 & 710 & 3,540 & $0.80 \S$ & $15 \S$ \\
\hline 1958 & Jun 1 & 3,000 & 3,000 & $0.80 \S$ & $15 \S$ \\
\hline 1958 & Oct 4 & 190 & 3,050 & $0.70 \S$ & $30 \S$ \\
\hline 1960 & Oct 2 & 130 & 1,310 & $0.60 \S$ & $40 \S$ \\
\hline 1962 & Nov 3 & 230 & 2,420 & $0.70 \S$ & $30 \S$ \\
\hline 1963 & Aug 22 & 60 & 230 & $0.70 \dagger$ & $30 \dagger$ \\
\hline 1964 & Apr 20 & 40 & 550 & $0.40 \S$ & $60 \S$ \\
\hline 1965 & May 18 & 790 & 1,290 & $0.70 \S$ & $30 \S$ \\
\hline 1966 & May 19 & 500 & 1,650 & $0.65 \dagger$ & $30 \dagger$ \\
\hline 1967 & Aug & 340 & 520 & $0.60 \dagger$ & $35 \dagger$ \\
\hline 1973 & Jun 19 & 390 & 1,080 & $0.75 \S$ & $20 \S$ \\
\hline 1989 & Oct 8 & 160 & 2,720 & $0.75 \S$ & $30 \S$ \\
\hline 1994 & Jun 1 & 240 & 970 & $0.60 \S$ & $30 \S$ \\
\hline 1995 & Mar 6 & 530 & 620 & $0.40 \#$ & $60 \#$ \\
\hline 1995 & May 30 & 260 & 530 & $0.50 \S$ & $50 \S$ \\
\hline
\end{tabular}

Notes: Constriction ratio and constriction percentage is described in the notes for table 6 and in the text. Values of $\mathrm{C}_{\mathrm{r}}$ are rounded to the nearest 0.05 ; values of $\mathrm{C}_{\mathrm{w}}$ are rounded to the nearest $5 \%$.

*Constriction data were determined by rectification of oblique ground photography (fig. 12) using image-processing software.

†Constriction data were determined by projection of the slopes of remnant deposits (Plate I) into the Colorado River.

$\S$ Constriction data were determined by rectification of aerial photography (fig. 21) using image processing software.

\#Constriction data were determined by survey.

frequency of debris flows in other Colorado River tributaries (Melis and others, 1994).

We used the estimated volumes of historic debris flows and the AD 1434 debris flow (table 6) to estimate a magnitude-frequency relation for aggraded debris fans; then assumed the frequency of production of debris fans at the mouth of Prospect Canyon could be approximated using a log-normal distribution. Because debris fans do not form every year, and years with zero volume are difficult to model using log-transformed data (Kite, 1988), the data were censored at a volume of 6,000 $\mathrm{m}^{3}$. We then used an existing maximum-likelihood procedure (Stedinger and Cohn, 1986; Stedinger and others, 1988) to fit a log-normal distribution. As a check of the distribution, we also fit a logPearson type III distribution, but the fitted skew coefficient was close to zero, again suggesting the log-normal distribution is the most appropriate to use.

The recurrence intervals for the debris fans provide a magnitude-frequency relation for historic debris flows from Prospect Canyon. Both the AD 1434 and 1939 debris flows are 150- to 200-yr events. The 1954 and 1966 debris flows, the smallest ones recorded from Prospect Canyon, are about 20-year events. Finally, the 1955, 1963, and 

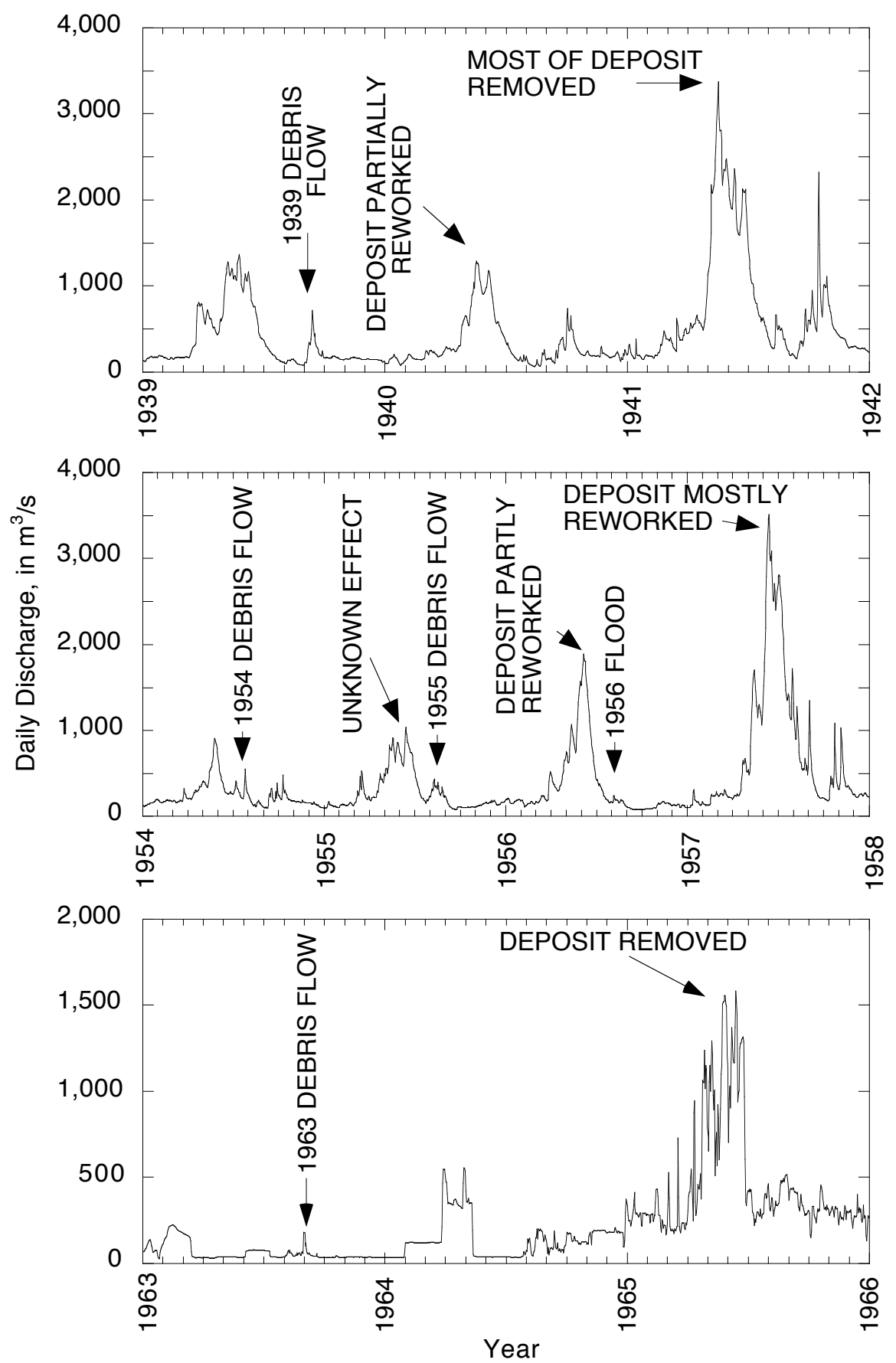

Figure 39. Hydrographs of the Colorado River showing the timing of tributary floods and debris flows and river discharges. A. 1939 to 1942 . B. 1954 to 1958 . C. 1963 to 1966. 
1995 debris flows are 55-, 45-, and 35-yr events, respectively.

\section{REWORKING OF DEBRIS FANS BY THE COLORADO RIVER}

Reworking of rapids by river floods was initially described by Graf $(1979,1980)$ and Howard and Dolan (1981). Kieffer (1985, 1987, 1990) presented a conceptual model for reworking of debris fans in Grand Canyon, incorporating elements from the previous studies. This model, based on alteration of Crystal Rapid during the large releases from Glen Canyon Dam in 1983 (Kieffer, 1985), consists of the stages of (1) damming of the river by a debris flow, (2) the river overtopping the debris fan, forming a "waterfall" on the downstream side, and (3) headcut progression from downstream to upstream across the debris fan, depending on discharges in the river. The history of reworking of the Prospect Canyon debris fan shows the instability of rapids controlled by debris flows, and suggests a modification of Kieffer's conceptual model.

The effectiveness of unregulated flood and dam releases in alleviating constrictions is extremely important. Before regulation in 1963 by Glen Canyon Dam, the 2-yr flood on the Colorado River was approximately $2,140 \mathrm{~m}^{3} / \mathrm{s}$; the $100-\mathrm{yr}$ flood was $5,650 \mathrm{~m}^{3} / \mathrm{s}$ (fig. 38). The largest historic flood was $8,500 \mathrm{~m}^{3} / \mathrm{s}$ in 1884 ; several prehistoric Holocene floods exceeded $8,500 \mathrm{~m}^{3} / \mathrm{s}$ and one may have been as large as $11,000 \mathrm{~m}^{3} / \mathrm{s}$ (Hereford and others 1993, 1996; O'Connor and others, 1994). Regulation by Glen Canyon Dam reduced the apparent 2-yr flood to about $890 \mathrm{~m}^{3} / \mathrm{s}$. Floods on the unregulated Colorado River were larger and of longer duration than dam releases (figs. 39, 40).

The 1995 debris flow in Prospect Canyon provides a good example of the interaction between the Colorado River and a newly aggraded debris fan. Immediately after the debris flow ceased, the Colorado River had a maximum $\mathrm{C}_{\mathrm{w}}$ of 60 percent, or about 34 percent more constricted than before the debris flow (table 7). Reworking by the Colorado River began immediately after cessation of the debris flow and lasted $12 \mathrm{hrs}$. Within that period, 45 percent $\left(4,200 \mathrm{~m}^{3}\right)$ of the volume of the debris fan was removed by the Colorado River; an additional $660 \mathrm{~m}^{3}$ was eroded by recessional flow in Prospect Canyon. Twelve hours after the deposition, 52 percent of the deposit was removed without overtopping of the debris fan by the Colorado River.

Reworking increased the median particle size $\left(\mathrm{d}_{50}\right)$ from $350 \mathrm{~mm}$ to $512 \mathrm{~mm}$ (fig. 41a) on the distal margin of the aggraded fan adjacent to Lava Falls Rapid. Reworking preferentially removed limestone; the reworked deposit was 90 percent basalt and 6 percent limestone (fig. 41b). The larger reworked particles were deposited in the pool downstream from the Black Rock in an elongated debris bar that is submerged shallowly at $263 \mathrm{~m}^{3} / \mathrm{s}$ (fig. 28b). This debris bar corresponds to Kieffer's (1990) "rock garden." During the reworking of March 6, existing waves in Lava Falls Rapid increased in size, but a hydraulic jump did not form either in response to or because of reworking, as Kieffer $(1985,1990)$ reported.

At the time of the Powell Expedition (figs. 11b, 12a), Lava Falls Rapid was wide with a constriction ratio of 0.75 and an average constriction of 5 percent (table 7). That the rapid did not change between 1872 and 1939 is significant because several large floods occurred in the Colorado River between 1921 and 1939 (fig. 38). The Pyramid and Deflector rocks, and boulders on the debris fan, were unaffected by floods in excess of $5,660 \mathrm{~m}^{3} / \mathrm{s}$ that occurred in 1884 and 1921; equivalent-sized floods also may have occurred 1891, 1905, and 1916. Photography taken in 1909 and 1934 at low water (figs. 14 and 17) show boulders in excess of $3 \mathrm{~m}$ in diameter on the bed in Lava Falls Rapid. The boulders were wedged together in groups; water flowing over the groups formed obstacles, large waves, and holes that compelled most expeditions to portage around the rapid.

The 1939 debris flow initially constricted the Colorado River by 80 percent. If the top of the 1939 levee is projected to the right bank of the Colorado River, the resulting width of the Colorado River would have been only $5.2 \mathrm{~m}$. The debris fan aggraded in 1939 (table 7) and the rapid was widened to an unknown extent by the 1941 flood (peak discharge of $3,400 \mathrm{~m}^{3} / \mathrm{s}$ ), but no rock garden formed below the rapid, as suggested by Kieffer's model. Photographs from the 1940s (figs. 18 and 19) show a slightly wider rapid than in the early 

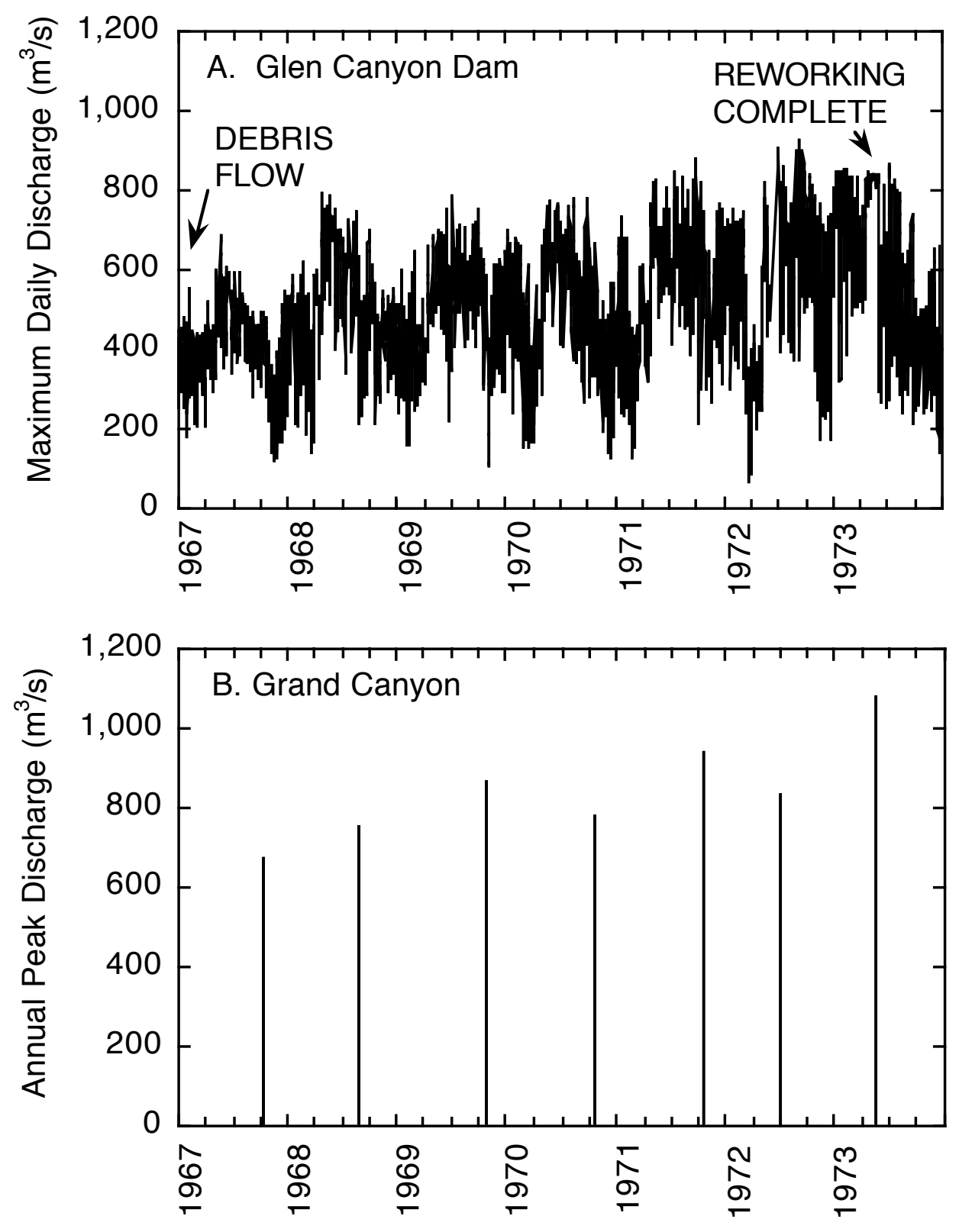

Figure 40. Hydrographs of the Colorado River from 1966 to 1974 showing the timing of the 1966 debris flow and releases from Glen Canyon Dam. A. Maximum daily discharge. B. Annual peak discharge. 

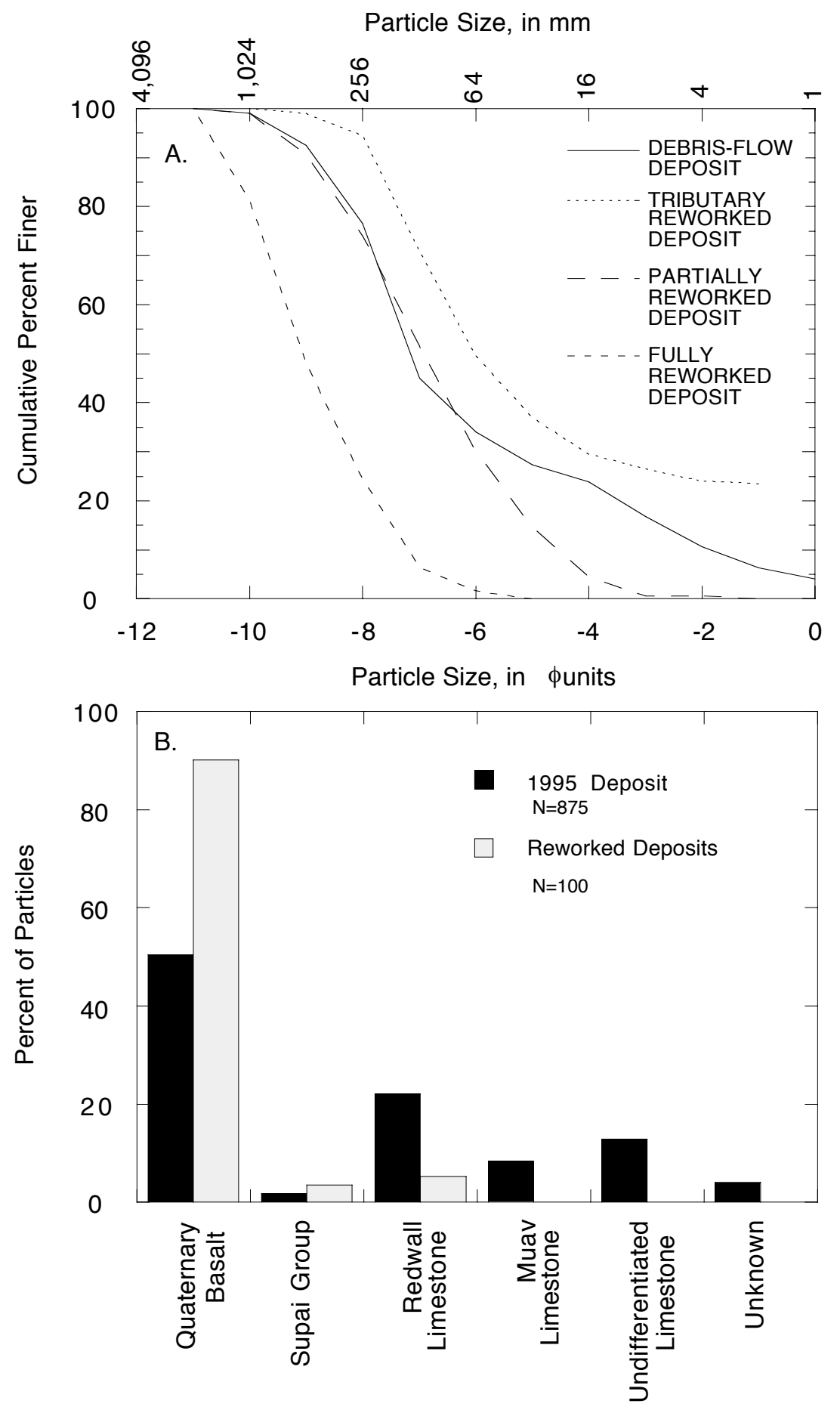

Figure 41. Effects of river reworking on particles on the Prospect Canyon debris fan. A. Comparison of the particlesize distribution on the reworked and intact distal margins of the debris-flow deposit. B. Comparison of rock types transported in the main lobe of the 1995 debris flow with the composition of rocks on the reworked debris fan. 
1990s, which suggests the constriction may have been less than 25 percent.

Two debris flows in the 1950s again constricted Lava Falls Rapid (table 7). The 1954 debris flow increased the constriction to 40 percent, but Colorado River discharges up to $540 \mathrm{~m}^{3} / \mathrm{s}$ reduced the constriction to about 30 percent by the following spring. The 1955 debris flow increased the constriction to 70 percent, which formed a stable configuration for nearly two years despite discharges up to $1,900 \mathrm{~m}^{3} / \mathrm{s}$ (table 7). Aerial photographs from 1956 and 1957 (figs. 21c and 21d) show that the debris fan was not overtopped; instead, the river eroded the margin of the debris fan and then transported boulders when river stage created sufficient stream power. The first photographs after the 1957 and 1958 floods, taken at low discharge in October 1958, showed a constriction of 30 percent (table 7).

The two debris flows in the 1960s, which occurred during the first 4 yrs of operation of Glen Canyon Dam (table 4), were reworked by unusual dam releases and (or) tributary floods (figs. 39 and 40). The 1963 debris flow caused a 60 percent constriction; the 1965 releases from Glen Canyon Dam, which peaked at $1,650 \mathrm{~m}^{3} / \mathrm{s}$, reduced the constriction to 30 percent. The 1966 debris flow created a 35 percent constriction, which was again reduced to 30 percent by 1994 (table 7). A powerplant release of $840 \mathrm{~m}^{3} / \mathrm{s}$ on May 26, 1972 partially reworked the debris fan, and the combination of low dam releases and a small flood in the Little Colorado River on April 17, 1973, created a peak discharge of $1,080 \mathrm{~m}^{3} / \mathrm{s}$, which eroded most of the aggraded debris fan. Additional changes in Lava Falls Rapid occurred during the $2,720 \mathrm{~m}^{3} / \mathrm{s}$ flood of 1983, but these were relatively minor. The amount of elapsed time from deposition to reworking increased from 1-2 yrs to 3-7 yrs because of the change in flow caused by operation of Glen Canyon Dam (fig. 38).

Not including the 1995 deposit, the total volume of sediment deposited by historic debris flows at Lava Falls Rapid was about $110,000 \mathrm{~m}^{3}$. Most of this sediment was reworked by the Colorado River, leaving a residual deposit of 2,000 $\mathrm{m}^{3}$ that increased the river's constriction from about 5 percent in 1872 to 30 percent in 1994 . Including the $4,800 \mathrm{~m}^{3}$ eroded from the 1995 debris fan, a total of $115,000 \mathrm{~m}^{3}$ of sediment was eroded from the debris fan and transported downstream. Approximately 70 percent of this volume $(86,000$ $\mathrm{m}^{3}$ ) was boulders (greater than $256 \mathrm{~mm}$, fig. 41a) that were transported to Lower Lava Rapid or downstream. This prodigious production of boulders is the reason the total drop from the top of Lava Falls Rapid to the bottom of the lowermost secondary riffle (1.4 km downstream) is $12 \mathrm{~m}$. The five alternating debris bars that control the downstream riffles are spread over a distance of 2 km downstream from Lava Falls (Stevens, 1990).

The history of aggraded debris fans and reworking by the Colorado River at Lava Falls Rapid provides the basis for a general model of debris fan evolution in Grand Canyon (fig. 42). Kieffer's $(1985,1987)$ model does not completely apply to reworking of debris fans at Lava Falls Rapid because historic debris flows from Prospect Canyon, or from other tributaries in Grand Canyon including Crystal Creek, have not crossed and dammed the Colorado River (Webb, 1996). Consequently, the "waterfall" that Kieffer hypothesized to occur on the downstream side of the newly aggraded debris fan is actually water flowing through the steepened, constricted rapid and around the distal margin of the debris fan. In the case of Lava Falls, $C_{w}$ of the aggraded debris fan is 60-80 percent (fig. 42b). Relatively low river discharges cause minor reworking (figs. 21c, 42c), whereas large Colorado River floods remove most of the debris-fan constriction and form secondary riffles downstream (fig. 42d). Because dam releases are typically much smaller than floods in the unregulated Colorado River (fig. 38), reworking of debris fans that formed in the last 30 yrs have mostly followed the model shown in Figure 42c, which is similar to Kieffer's model.

\section{DISCUSSION AND CONCLUSIONS}

Lava Falls Rapid is a formidable reach of whitewater and an example of how tributaries control the grade and hydraulics of a major river. Lava Falls previously was assumed to be an unchanging rapid controlled by the remnants of Pleistocene basalt dams. Instead, we have shown that Lava Falls is the most unstable rapid in Grand Canyon owing to frequent debris flows from Prospect Canyon. The highest deposits on the 


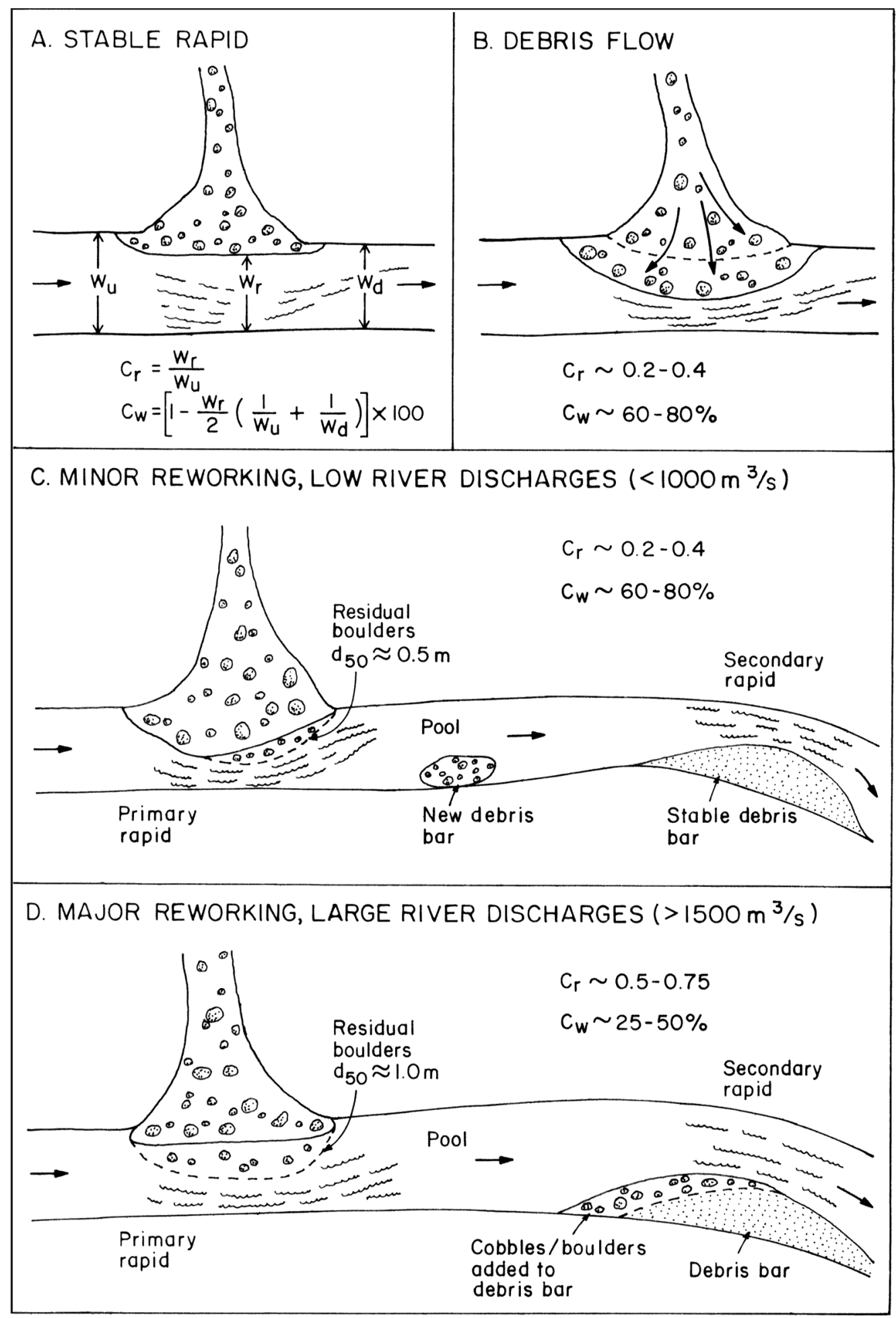

Figure 42. Diagram of one cycle of debris-flow deposition and river reworking at Lava Falls Rapid. A. The "stable rapid" at Lava Falls, as exemplified by the configuration present from 1872 to 1939, has a constriction ratio of about 0.75 and has an average constriction of about 3 percent. B. Debris flows seldom dam the Colorado River. Instead, deposition generally constricts the river by $60-80$ percent and creates a constriction ratio of 0.2-0.4. C. Small pre-dam floods and typical dam releases erode only the downstream side of the debris fan and do not significantly widen the constriction. Debris eroded from the debris fan is deposited downstream in the pool adjacent to the tail waves. D. Large pre-dam floods, and unusual dam releases such as in June 1983, typically remove most of the constriction, leaving a residual lag of boulders in the rapid. In the 20th century, the resultant constriction ratio and constrictions did not return to the 1872 condition $(\mathrm{A})$. Cobbles are transported through the pool and deposited on the debris bar downstream. 
debris fan, deposited about $950 \mathrm{BC}$, indicate predominant late Holocene aggradation of one of the largest debris fans in Grand Canyon. Moreover, the $950 \mathrm{BC}$ debris flow raised the base level of the Colorado River by $30 \mathrm{~m}$ before the deposit was reworked. At Granite Park, 30 river miles downstream, Lucchita and others (1995) indicate $10 \mathrm{~m}$ of downcutting in the last $11 \mathrm{ka}$. This downcutting indicates that the local effects of debris flows on the river corridor may be of the same magnitude as downcutting of Grand Canyon in the Holocene.

Prospect Canyon has produced the highest frequency of debris flows of any tributary in Grand Canyon (Melis and others, 1994). Depending on the interval chosen, the frequency of debris flows ranges from one every 5 years to one every 20 years. Debris flows were not random in the historical period: from April 1872 to July 1939, there were no debris flows in Prospect Canyon, whereas five debris flows occurred in a 27 -yr period between 1939 and 1966. Because debris flows do not appear to be related to regional hydroclimatology, we attribute the nonstationarity in debris-flow occurrence to destabilization of colluvial wedges and channel deposits in Prospect Canyon. As the sediment sources diminish, the frequency of debris flows is expected to decline.

Debris flows occur more frequently in Prospect Canyon owing to several significant differences from other debris-flow producing tributaries in Grand Canyon. Because of its large drainage area, the Prospect Valley drainage basin produces runoff in response to regional storms as well as summer thunderstorms, which have caused most of the historic debris flows in Grand Canyon. Debris flows are produced in Prospect Canyon solely by the firehose effect from a channel draining a large area; failure of bedrock units as well as colluvium initiated the largest debris flows from other tributaries (Melis and others, 1994). The basalt plug that creates the $325-\mathrm{m}$ waterfall at the head of Prospect Canyon is a lithologic control that exists only in Prospect Canyon, the drainage from Toroweap Valley (on the opposite side of the river from Prospect Canyon), and Whitmore Wash. The latter two drainages do not produce significant debris flows.

The regional hydroclimatology strongly influences debris-flow initiation in Prospect
Canyon. The results of Hereford and Webb (1992) and Hereford and others (1993) are verified in our analysis of precipitation anomalies in western Grand Canyon, which shows a general decline in summer precipitation, particularly after 1970 (fig. 32a). This is significant because August and September precipitation has produced more than 90 percent of debris flows since 1939 (Melis and others, 1994). Hereford and Webb (1992) showed that precipitation from dissipating tropical cyclones has declined on the Colorado Plateau except for the years 1972 and 1983, when precipitation from this source was well above normal. Although summer precipitation has declined, winter precipitation has increased (fig. 32b) and the last 2 debris flows from Prospect Canyon have occurred during regional winter storms.

The instability of Lava Falls Rapid is best illustrated by the alteration of primary hydraulic features and the historical constrictions. Debris flows in 1939, 1954, 1955, 1963, and 1966 changed the pattern of flow through Lava Falls Rapid, creating the hydraulic features so well known to river runners (fig. 11b). Before 1939, the constriction percentage at Lava Falls was only 5 percent (table 7). In 1939, the rapid was constricted by 80 percent, which is the largest historic constriction known in Grand Canyon. The interaction of debris flows and reworking by the Colorado River increased the average constriction from 5 percent in 1872 to 30 percent in 1994. A debris flow in March 1995 increased the constriction from 30 to 60 percent; half a day of Colorado River flow reduced the constriction to 50 percent. Lighter lithologies, such as sandstone and limestone, were preferentially removed, leaving a lag deposit of mostly basalt (fig. 41b).

Lava Falls Rapid represents the long-term effect of frequent debris-flow deposition and mainstem reworking. Between 1872 and 1939, Lava Falls Rapid did not change despite large Colorado River floods in 1884 and 1921. Smaller river floods that occurred after the 1939, 1954, and 1955 debris flows reworked most of the deposits within 2 yrs. The 1963 and 1966 debris-fan deposits were removed by even smaller releases from Glen Canyon Dam in 3-7 yrs. Rapids may be stable for long periods between debris flows despite the occurrence of long recurrence-interval floods, 
particularly if suturing of boulders occurs on the bed of the rapid (Webb, 1996).

Two previous estimates of the magnitude of floods necessary to rework debris fans are considerably higher than the discharges that have reworked the Prospect Canyon debris fan. Kieffer (1985) concluded that a Colorado River flood of $11,300 \mathrm{~m}^{3} / \mathrm{s}$ is necessary to widen a severely constricted rapid, such as Crystal Rapid, to $C_{r}=$ 0.50 , the average constriction ratio of rapids in Grand Canyon (fig. 37). At Warm Springs Rapid on the Yampa River in Utah, Hammack (1994) estimated that a discharge of $2,750 \mathrm{~m}^{3} / \mathrm{s}$ (a 500 $1,000 \mathrm{yr}$ flood) would be required to remove most of the debris fan aggraded in 1965. As the history of Lava Falls Rapid shows, historic floods of only $3,400 \mathrm{~m}^{3} / \mathrm{s}$ were sufficient to widen the more severely constricted Lava Falls to a 30 percent constriction $(\mathrm{Cr}=0.70)$ in 1939. Kieffer's (1985) argument was based on the change in mean velocity through the rapid as the constriction is removed and the velocity required to initiate boulder transport. Our findings indicate that the primary mechanism that widens rapids is lateral channel erosion of the debris fan, not entrainment of individual boulders from the top of the debris fan. Boulders enclosed in a poorly sorted matrix that are mobilized by lateral erosion have initial motion, which allows for transport by lower discharges.

The history of Lava Falls Rapid illustrates that most rapids are not an equilibrium fluvial form unless viewed strictly in the short intervals between debris flows. We concur with Howard and Dolan (1981), who concluded the position of rapids in Grand Canyon is not controlled by equilibrium river processes as previously reported (Leopold, 1969), but instead is controlled by point sediment sources, typically tributaries. Secondary riffles and rapids - such as Lower Lava Rapid - are also controlled by tributaries because reworking of aggraded debris fans at tributary junctures provides the boulders and cobbles that compose the controlling debris bar. Lava Falls Rapid also shows that rapids are not necessarily controlled by events that occurred in a different climatic regime (Graf, 1979); the debris flow that dammed the Colorado River about $950 \mathrm{BC}$ did not occur in a climate that was significantly different from the 20th century (Webb, 1996). Rapids that appear stable and of great antiquity may be so only until the next debris flow triggers changes by constricting the river or adding boulders to the rapid.

Rapids in bedrock canyons controlled by tributary alluvium are aggradational features that reflect the net effect of tributary-mainstem interactions (Graf, 1979). The boulders that form the core of rapids in Grand Canyon are essentially immobile by both dam releases and by unregulated Colorado River floods, although boulders with baxis diameters as large as $4 \mathrm{~m}$ have been dislodged and moved short distances. The presence of rapids such as Lava Falls indicate the river's erosional energy is mostly expended in abrading and removing boulders, not in eroding bedrock.

Dam operations have decreased reworking of debris fans at the mouths of tributary canyons. Graf (1980), in an analysis of debris fans on the Green River in northern Utah, concluded that 62 percent of the rapids were stable before construction of Flaming Gorge Dam, but that 93 percent of the rapids were stable after the dam began operation. Kieffer's (1985) study of Crystal Rapid suggests the 1966 debris fan could only be removed by a flood larger than the largest historical discharge in the Colorado River $\left(6,200 \mathrm{~m}^{3} / \mathrm{s}\right)$. At Lava Falls, two debris fans that formed after closure of Glen Canyon Dam were completely removed by flows that were less than the pre-dam 2-yr flood. Although previous studies suggest otherwise, historical reworking of Lava Falls Rapid indicates that modest dam releases - in the case of Glen Canyon Dam, above the powerplant capacity of 890 $\mathrm{m}^{3} / \mathrm{s}$ - could significantly rework aggraded debris fans. Some aggraded debris fans, such as the one at Crystal Rapid, would be unaffected, but others may be totally removed.

A comparison of the response of Crystal and Lava Falls rapids illustrates why it is difficult to make generalizations about the stability of rapids. Debris flows constricted both rapids after closure of Glen Canyon Dam, but the interaction of the river with the aggraded debris fans is different. The difference is explained largely by the size of boulders that composed the aggraded debris fans; whereas the 1963 debris flow was relatively finegrained $\left(\mathrm{d}_{50}=64 \mathrm{~mm}\right)$ and contained relatively small boulders, the 1966 debris flow at Crystal Rapid had very coarse particles $\left(\mathrm{d}_{50}=256 \mathrm{~mm}\right.$; 
Kieffer, 1987) and very large boulders. If a debris flow similar to the 1939 event had occurred at Lava Falls in 1963, the debris fan might have had a history similar to that of the Crystal Rapid debris fan.

The 1963 debris flow at Lava Falls Rapid was largely removed by dam releases of $1,640 \mathrm{~m}^{3} / \mathrm{s}$ in 1965 because the debris fan had not been significantly reworked (figs. 23b, 24). Reworking by typical powerplant releases armors the distal margin with boulders and cobbles that may be interlocked. This armoring greatly increases the necessary tractive stress needed for entrainment. The 1965 releases cut laterally into the deposit and entrained boulders up to $1 \mathrm{~m}$ in diameter. The debris fan at Crystal Rapid, enlarged in 1966, was first reworked by about $1,080 \mathrm{~m}^{3} / \mathrm{s}$ in 1973 ; major changes occurred only when dam releases exceeded $1,410 \mathrm{~m}^{3} / \mathrm{s}$ and peaked at $2,720 \mathrm{~m}^{3} / \mathrm{s}$ in 1983 . Although the Crystal Creek debris fan was significantly reworked, its distal edge is armored and should withstand most dam releases. As shown in Figure 30c, the distal margin of the 1995 debrisflow deposit, reworked by powerplant releases less than $560 \mathrm{~m}^{3} / \mathrm{s}$, is also armored.

Historic reworking of debris fans at Lava Falls Rapid has implications for dam operations, if periodic aggradation of debris fans is a management consideration. Because releases from Glen Canyon Dam are limited by the size of its powerplant, spillways, and jet tubes, the frequency of large releases that could significantly rework debris fans is low and is related to floods on the Paria and Little Colorado Rivers. Because the Little Colorado River has a flood of record of $3,390 \mathrm{~m}^{3} / \mathrm{s}$ and has a larger drainage area, the Little Colorado River is more likely to generate a debris-fan reworking flood than the Paria River, which has a flood of record of $455 \mathrm{~m}^{3} / \mathrm{s}$ (Garrett and Gellenbeck, 1991). The magnitude of regulated flows designed to alter the river corridor need to be large enough to remove most recently aggraded debris fans without significantly armoring their distal edges. If significant armoring develops, or boulders become sutured together, dam releases will be ineffectual in removing aggraded debris fans.

\section{REFERENCES CITED}

Aldridge, B.N., and Eychaner, J.H., 1984, Floods of October 1977 in southern Arizona and March 1978 in central Arizona: U.S. Geological Survey WaterSupply Paper 2223, $143 \mathrm{p}$.

Apmann, R.P., 1973, Estimating discharge from superelevation in bends: Journal of the Hydraulics Division, Proceedings of the American Society of Civil Engineers, HY1, p. 65-79.

Baker, V.R., Pickup, G., and Polach, H.A., 1985, Radiocarbon dating of flood events, Katherine Gorge, Northern Territory, Australia: Geology, v. 13, p. 344-347.

Beverage, J.P., and Culbertson, J.K., 1964, Hyperconcentrations of suspended sediment: American Society of Civil Engineers, Journal of the Hydraulics Division, v. 90, p. 117-126.

Billingsley, G.H., Jr., and Huntoon, P.W., 1983, Geologic map of Vulcans Throne and vicinity, western Grand Canyon, Arizona: Grand Canyon, Arizona, Grand Canyon Natural History Association Map, scale 1:62,500, 1 sheet.

Birdseye, C.H., 1924, Plan and profile of the Colorado River from Lees Ferry, Arizona, to Black Canyon, Arizona-Nevada, and the Virgin River, Nevada: U.S. Geological Survey map publication, 21 sheets (A-U) scale 1:36,680.

Birkeland, P.W., 1984, Soils and geomorphology: New York, Oxford University Press, 372 p.

Blackwelder, E., 1928, Mudflow as a geologic agent in semiarid mountains: Geological Society of America Bulletin, v. 39, p. 465-494.

Bowers, J.E., Webb, R.H., and Pierson, E.A., 1996, Primary succession of desert plants on debris-flow terraces, Grand Canyon, Arizona, U.S.A.: Journal of Arid Environments.

Brian, N., 1992, River to rim: Flagstaff, Earthquest Press, $176 \mathrm{p}$.

Butler, E., and Mundorff, J.C., 1970, Floods of December 1966 in southwestern Utah: U.S. Geological Survey Water-Supply Paper 1870-A, 40 p.

Carmony, N.B., and Brown, D.E., 1987, The log of the Panthon: Boulder, Colorado, Pruett Publishing, 109 p.

Cerling, T.E., and Craig, H., 1994, Geomorphology and in-situ cosmogenic isotopes: Annual Reviews in Earth and Planetary Sciences, v. 22, p. 273-317. 
Cerling, T.E., Poreda, R.J., and Rathburn, S.L., 1994, Cosmogenic ${ }^{3} \mathrm{He}$ and ${ }^{21} \mathrm{Ne}$ age of the Big Lost River flood, Snake River Plain, Idaho: Geology, v. 22, p. 227-230.

Cerling, T.E., Rigby, A., Webb, R.H., and Poreda, R.J., 1995, Cosmogenic ${ }^{3} \mathrm{He}$ exposure ages of debris flows and lava dam outburst floods in the Grand Canyon, USA: EOS, v 76, p. F684.

Clark, G.W., and Newcomb, Duane, 1977, Georgie Clark, Thirty years of river running: San Francisco, Chronicle Books, 165 p.

Cook, W., 1987, The Wen, the Botany, and the Mexican Hat: Orangevale, California, Callisto Books, 151 p.

Cooke, R., Warren, A., and Goudie, A., 1993, Desert geomorphology: London, University College London Press, 526 p.

Cooley, J., 1988, The great unknown: Flagstaff, Arizona, Northland Publishing, 207 p.

Cooley, M.E., Aldridge, B.N., and Euler, R.C., 1977, Effects of the catastrophic flood of December, 1966, North Rim area, eastern Grand Canyon, Arizona: U.S. Geological Survey Professional Paper 980, 43 p.

Costa, J.E., 1984, Physical geomorphology of debris flows, in Costa, J.E., and Fleisher, P.J., editors, Developments and applications of geomorphology: Berlin, Springer-Verlag Publishing, p. 268-317.

Costa, J.E., and O'Connor, J.E., 1995, Geomorphically effective floods, in Natural and anthropogenic influences in fluvial geomorphology: American Geophysical Union, Geophysical Monograph 89, p. 45-56.

Dolan, R., Howard, A., and Trimble, D., 1978, Structural control of the rapids and pools of the Colorado River in the Grand Canyon: Science, v. 202, p. 629-631.

Eddy, C., 1929, Down the world's most dangerous river: New York, Frederick A. Stokes Company, 293 p.

Ely, L.L., Webb, R.H., and Enzel, Yehouda, 1992, Accuracy of post-bomb ${ }^{137} \mathrm{Cs}$ and ${ }^{14} \mathrm{C}$ in dating fluvial deposits: Quaternary Research, v. 38, p. 196204.

Ferguson, C.W., 1971, Tree-ring dating of Colorado River driftwood in the Grand Canyon: Proceedings of the 1971 meetings of the Arizona Section, American Water Resources Association, and the Hydrology Section, Arizona Academy of Science, v. 1, p. 351-366.
Fowler, D.D. (editor), 1972, "Photographed all the best scenery," Jack Hillers's diary of the Powell Expeditions, 1871-1875: Salt Lake City, University of Utah Press, 225 p.

Fradkin, P.L., 1984, A river no more: Tucson, University of Arizona press, $360 \mathrm{p}$.

Freeman, L.R., 1924, Surveying the Grand Canyon of the Colorado: National Geographic Magazine, v. 45, p. 471-531, 547-548.

Friedman, G.M., and Sanders, J.E., 1978, Principles of sedimentology: New York, John Wiley and Sons, $792 \mathrm{p}$.

Gallino, G.L., and Pierson, T.C., 1985, Polallie Creek debris flow and subsequent dam-break flood of 1980, East Fork Hood River basin, Oregon: U.S. Geological Survey Water-Supply Paper 2273, 22 p.

Garrett, J.M., and Gellenbeck, D.J., 1991, Basin characteristics and streamflow statistics in Arizona as of 1989: U.S. Geological Survey WaterResources Investigations Report 91-4041, 612 p.

Ghiglieri, M.P., 1992, Canyon: Tucson, Arizona, University of Arizona Press, $311 \mathrm{p}$.

Glancy, P.A., 1969, A mudflow in the Second Creek drainage, Lake Tahoe Basin, Nevada, and its relation to sedimentation and urbanization: U.S. Geological Survey Professional Paper 650C, p. C195-C200.

Goldwater, B.M., 1940, A journey down the Green and Colorado Rivers: Phoenix, Arizona, privately published by H. Walker Publishing, 106 p.

Graf, W.L., 1979, Rapids in canyon rivers: Journal of Geology, v. 87, p. 533-551.

Graf, W.L., 1980, The effect of dam closure on downstream rapids: Water Resources Research, v. 16 , p. $129-136$.

Granger, B.H., 1960, Grand Canyon place names: Tucson, University of Arizona Press, 26 p.

Griffiths, P.G., 1995, Initiation and frequency of debris flows in Grand Canyon, Arizona [M.S. Thesis]: Tucson, University of Arizona, $52 \mathrm{p}$.

Hamblin, W.K., 1990, Late Cenozoic lava dams in the western Grand Canyon, in Beus, S.S., and Morales, M. (editors), Grand Canyon geology: New York, Oxford University Press, p. 385-433.

Hamblin, W.K., 1994a, Rates of erosion by the Colorado River in the Grand Canyon, Arizona: Proceedings of the 29th International Geology Congress, Part B, p. 211-218. 
Hamblin, W.K., 1994b, Late Cenozoic lava dams in the western Grand Canyon: Geological Society of America Memoir 183, 139 p.

Hamblin, W.K., and Rigby, J.K., 1968, Guidebook to the Colorado River, Part 1, Lee's Ferry to Phantom Ranch in Grand Canyon National Park: Provo, Utah, Brigham Young University, Geology Studies, v. 15, part 5, 84 p.

Hammack, L.A., 1994, Debris-fan formation and rapid modification at Warm Springs Rapid, Yampa River, Colorado [M.S. Thesis]: Fort Collins, Colorado State University, $125 \mathrm{p}$.

Hampton, M.A., 1975, Competence of fine-grained debris flows: Journal of Sedimentary Petrology, v. 45 , p. 834-844.

Hansen, E.M., and Shwarz, F.K., 1981, Meteorology of important rainstorms in the Colorado River and Great Basin drainages: National Oceanic and Atmospheric Administration, Hydrometeorological Report 50, 167 p.

Heald, W., 1948, The eighteenth expedition, in Peattie, R. (editor), The inverted mountains: New York, Vanguard Press, p. 195.

Hereford, Richard, 1984, Driftwood in Stanton's Cave: The case for temporary damming of the Colorado River at Nankoweap Creek in Marble Canyon, Grand Canyon National Park, Arizona, in Euler, R.C. (editor), The archaeology, geology, and paleobiology of Stanton's Cave, Grand Canyon National Park, Arizona: Grand Canyon, Arizona, Grand Canyon Natural History Association Monograph Number 6, p. 99-106.

Hereford, R., 1996, Map showing surficial geology and geomorphology of the Palisades Creek area, Grand Canyon National Park, Arizona: U.S. Geological Survey Miscellaneous Investigations Series Map I2449, scale 1:2,000.

Hereford, R., and Webb, R.H., 1992, Historic variation in warm-season rainfall on the Colorado Plateau, U.S.A.: Climatic Change, v. 22, p. 239-256.

Hereford, R., Fairley, H.C., Thompson, K.S., and Balsom, J.R., 1993, Surficial geology, geomorphology, and erosion of archaeologic sites along the Colorado River, eastern Grand Canyon, Grand Canyon National Park, Arizona: U.S. Geological Survey Open-File Report 93-517, 46 p.
Hereford, R., Thompson, K.S., Burke, K.J., and Fairley, H.C., 1996, Tributary debris fans and the late Holocene alluvial chronology of the Colorado River, eastern Grand Canyon, Arizona: Geological Society of America Bulletin, v. 108, p. 3-19.

Hirschboeck, K.K., 1985, Hydroclimatology of flow events in the Gila River Basin, central and southern Arizona [Ph.D dissertation]: Tucson, University of Arizona, 335 p.

Howard, A.D., and Dolan, Robert, 1979, Changes in the fluvial deposits of the Colorado River in the Grand Canyon caused by Glen Canyon Dam, in Linn, R.M. (editor), Proceedings of the First Conference on Scientific Research in the National Parks, Volume II, p. 845-851.

Howard, Alan, and Dolan, Robert, 1981, Geomorphology of the Colorado River in Grand Canyon: Journal of Geology, v. 89, p. 269-297.

Jackson, G.W., 1990a, The Toroweap Fault - One of the most active faults in Arizona: Arizona Geology, v. 20, p. 7-10.

Jackson, G.W., 1990b, Tectonic geomorphology of the Toroweap Fault, western Grand Canyon, Arizona: Implications for transgression of faulting on the Colorado Plateau: Tucson, Arizona Geological Survey Open-File Report 90-4, 67 p.

Johnson, A.M., and Rodine, J.R., 1984, Debris flow, in Brunsden, D., and Prior, D.B. (editors), Slope instability: New York, John Wiley and Sons, p. 257361 .

Kieffer, S.W., 1985, The 1983 hydraulic jump in Crystal Rapid: Implications for river-running and geomorphic evolution in the Grand Canyon: Journal of Geology, v. 93, p. 385-406.

Kieffer, S.W., 1987, The rapids and waves of the Colorado River, Grand Canyon, Arizona: U.S. Geological Survey Open-File Report 87-096, 69 p.

Kieffer, S.W., 1988, Hydraulic map of Lava Falls Rapid, Grand Canyon, Arizona: U.S. Geological Survey Miscellaneous Investigations Series, Map I-1897-J, scale $1: 1,000,1$ sheet.

Kieffer, S.W., 1990, Hydraulics and geomorphology of the Colorado River in the Grand Canyon, in Beus, S.S., and Morales, M. (editors), Grand Canyon geology: New York, Oxford University Press, p. 333-383.

Kite, G.W., 1988, Frequency and risk analyses in hydrology: Littleton, Colorado, Water Resources Publications, 257 p. 
Kolb, E.L., 1914, Through the Grand Canyon from Wyoming to Mexico: New York, MacMillan Company, 344 p.

Lavender, D., 1985, River runners of the Grand Canyon: Grand Canyon, Arizona, Grand Canyon Natural History Association, 147 p.

Leopold, L.B., 1969, The rapids and the pools - Grand Canyon, in The Colorado River region and John Wesley Powell: U.S. Geological Survey Professional Paper 669, p. 131-145.

Lindemann, L.L., and Lindemann, D.K., 1995, Colorado River briefs for a trip through the Grand Canyon: Tucson, Arizona, Lundquist Press, 152 p.

Lucchitta, I., Curtis, G., Davis, M.E., Davis, S.W., and Turrin, B., 1995, Quaternary geology of the Granite Park area, Grand Canyon: Aggradationdowncutting cycles, calibration of soils stages, and response of fluvial system to volcanic activity: U.S. Geological Survey Open-File Report 95-, 62 p.

Machette, M.N., 1985, Calcic soils of the southwestern United States: Geological Society of America Special Paper 203, p. 1-21.

Marston, O.D., 1976, Separation marks, notes on "the Worst Rapid" in the Grand Canyon: Journal of Arizona History, v. 17, p. 1-20.

McFadden, L.D., and Tinsley, J.C., 1985, Rate and depth of pedogenic-carbonate accumulation in soils: Formulation and testing of a compartment model: Geological Society of America Special Paper 203, p. 23-41.

Melis, T.S., and Webb, R.H., 1993, Debris flows in Grand Canyon National Park, Arizona Magnitude, frequency and effects on the Colorado River, in Shen, H.W., Su, S.T., and Wen, F., (editors), Hydraulic Engineering '93: New York, American Society of Civil Engineers, Proceedings of the ASCE Conference, San Francisco, California, p. 1290-1295.

Melis, T.S., Webb, R.H., Griffiths, P.G, and Wise, T.J., 1994, Magnitude and frequency data for historic debris flows in Grand Canyon National Park and vicinity, Arizona: U.S. Geological Survey Water Resources Investigations Report 94-4214, 285 p.

Meyer, G.A., Wells, S.G., and Jull, A.J.T., 1995, Fire and alluvial chronology in Yellowstone National Park - Climatic and intrinsic controls on Holocene geomorphic processes: Geological Society of America Bulletin, v. 107, p. 1211-1230.
Nash, R.F., 1989, The big drops, ten legendary rapids of the American west: Boulder, Colorado, Johnson Books, 216 p.

O’Connor, J.E., Ely, L.L., Wohl, E.E., Stevens, L.E., Melis, T.S., Kale, V.S., and Baker, V.R., 1994, A 4500-year record of large floods on the Colorado River in the Grand Canyon, Arizona: Journal of Geology, v. 102, p. 1-9.

Osterkamp, W.R., Hupp, C.R., and Blodgett, J.C., 1986, Magnitude and frequency of debris flows, and areas of hazard on Mount Shasta, Northern California: U.S. Geological Survey Professional Paper 1396-C, $21 \mathrm{p}$.

Péwé, T.L., 1968, Colorado River guidebook, Lees Ferry to Phantom Ranch: Tempe, Arizona, privately published, $78 \mathrm{p}$.

Phillips, B.G., Phillips, A.M., III, and Bernzott, M.A.S., 1987, Annotated checklist of vascular plants of Grand Canyon National Park: Grand Canyon Natural History Association Monograph Number 7, $79 \mathrm{p}$.

Pierson, T.C., 1985, Initiation and flow behavior of the 1980 Pine Creek and Muddy River lahars, Mount St. Helens, Washington: Geological Society of America Bulletin, v. 96, p. 1056-1069.

Pierson, T.C., and Scott, K.M., 1985, Downstream dilution of a lahar - transition from debris flow to hyperconcentrated streamflow: Water Resources Research, v. 21, p. 1511-1524.

Pierson, T.C., and Costa, J.E., 1987, A rheologic classification of subaerial sediment-water flows: Reviews in Engineering Geology, v. 7, p. 1-12.

Poreda, R.J., and Cerling, T.E., 1992, Cosmogenic neon in recent lavas from the western United States: Geophysical Research Letters, v. 19, p. 1863-1866.

Postma, G., 1986, Classification for sediment gravityflow deposits based on flow conditions during sedimentation: Geology, v. 14, p. 291-294.

Powell, J.W., 1875, Exploration of the Colorado River of the West and its tributaries: Washington, D.C., 43rd U.S. Congress, 1st Session, House Miscellaneous Document 300, $291 \mathrm{p}$.

Rihs, J., 1995, Analysis of the March 1995 Bright Angel Creek flood event, Grand Canyon National Park: Grand Canyon, Arizona, Division of Resource Management Report, 11 p.

Rodine, J.D., and Johnson, A.R., 1976, The ability of debris, heavily freighted with coarse clastic materials, to flow on gentle slopes: Sedimentology, v. 23 , p. 213-234. 
Roeske, R.H., Cooley, M.E., and Aldridge, B.N., 1978, Floods of September 1970 in Arizona, Utah, Colorado, and New Mexico: U.S. Geological Survey Water-Supply Paper 2052, 135 p.

Roeske, R.H., Garrett, J.M., and Eychaner, J.H., 1989, Floods of October 1983 in southeastern Arizona: U.S. Geological Survey Water-Resources Investigations Report 85-4225-C, 77 p.

Schmidt, J.C., 1990, Recirculating flow and sedimentation in the Colorado River in Grand Canyon, Arizona: Journal of Geology, v. 98, p. 709724.

Schmidt, J.C., and Graf, J.B., 1990, Aggradation nd degradation of alluvial sand deposits, 1965-1986, Colorado River, Grand Canyon National Park, Arizona: U.S. Geological Survey Professional Paper 1493, 74 p.

Schmidt, J.C., and Rubin, D.M., 1995, Regulated streamflow, fine-grained deposits, and effective discharge in canyons with abundant debris fans, in Natural and Anthropogenic Influences in Fluvial Geomorphology: Washington, D.C., American Geophysical Union, Geophysical Monograph 89, p. 177-195.

Scott, K.M., 1988, Origins, behavior, and sedimentology of lahars and lahar-runout flows in the ToutleCowlitz river system: U.S. Geological Survey Professional Paper 1447-A, 74 p.

Sharp, R.P., and Nobles, L.H., 1953, Mudflow of 1941 at Wrightwood, southern California: Geological Society of America Bulletin, v. 64, p. 547-560.

Simmons, G.C., and Gaskill, D.L., 1969, River runner's guide to the canyons of the Green and Colorado Rivers, with emphasis on geologic features, Volume III, Marble Gorge and Grand Canyon: Flagstaff, Arizona, Northland Press, 132 p.

Smith, D.L., and Crampton, C.G. (editors), 1987, The Colorado River survey: Salt Lake City, Utah, Howe Brother Books, 305 p.

Smith, W., 1986, The effects of eastern North Pacific tropical cyclones on the southwestern United States: Salt Lake City, Utah, National Oceanic and Atmospheric Administration, Technical Memorandum NWS-WR-197, 229 p.

Stedinger, J.R., and Cohn, T.A., 1986, Flood frequency analysis with historical and paleoflood information:Water Resources Research, v. 22, p. 785-793.
Stedinger, J., Surani, R., and Therivel, R., 1988, MAX users guide: Ithaca, NY, Cornell University, Department of Environmental Engineering, no page numbers.

Stephens, H.G., and Shoemaker, E.M., 1987, In the footsteps of John Wesley Powell: Boulder, Colorado, Johnson Books, 286 p.

Stevens, L., 1990, The Colorado River in Grand Canyon, A guide: Flagstaff, Red Lake Books, 115 p.

Stone, J.F., 1932, Canyon country: New York, G.P. Putnam's Sons, $442 \mathrm{p}$.

Stuiver, M., and Becker, B., 1993, High-precision calibration of the radiocarbon time scale AD 19506000 BC: Radiocarbon, v. 35, p. 35-65.

Stuiver, M., and Reimer, P.J., 1993, CALIB user's guide for Macintosh computers, Rev 3.0.3A: Seattle, Washington, Quaternary Research Center publication.

Thomas, B.E., Hjalmarson, H.W., and Waltemeyer, S.D., 1994, Methods of estimating magnitude and frequency of floods in the southwestern United States: U.S. Geological Survey Open-file Report 93419, 211 p.

Thomas, H.E., 1962, The meteorologic phenomenon of drought in the Southwest: U.S. Geological Survey Professional Paper 372-A, 42 p.

U.S. Department of Commerce, 1963, Arizona, Hourly precipitation data, September 1963: U.S. Department of Commerce, Environmental Science Services Administration, v. 13, no. 9, 5 p.

U.S. Department of Commerce, 1966, Arizona, Hourly precipitation data, December 1966: U.S. Department of Commerce, Environmental Science Services Administration, v. 16, no. 12, 5 p.

U.S. Water Resources Council, 1981, Guidelines for determining flood flow frequency: Hydrology Subcommittee Bulletin 17B, 183 p.

Vasek, F.C., 1980, Creosote bush, long-lived clones in the Mojave Desert: American Journal of Botany, v. 67, p. 246-255.

Webb, R.H., 1996, Grand Canyon, a century of environmental change: Rephotography of the 18891890 Stanton expedition: Tucson, University of Arizona Press, 290 p.

Webb, R.H., and Betancourt, J.L., 1992, Climatic variability and flood frequency of the Santa Cruz River, Pima County, Arizona: U.S. Geological Survey Water-Supply Paper 2379, 40 p.

Webb, R.H., and Melis, T.S., 1995, The 1995 debris flow at Lava Falls Rapid: Nature Notes, v. 11, p. 1-4. 
Webb, R.H., Steiger, J.W., and Turner, R.M., 1987, Dynamics of Mojave Desert shrub vegetation in the Panamint Mountains: Ecology, v. 50, p. 478-490.

Webb, R.H., Pringle, P.T., Reneau, S.L., and Rink, G.R., 1988a, Monument Creek debris flow, 1984: Implications for formation of rapids on the Colorado River in Grand Canyon National Park: Geology, v. 16, p. 50-54.

Webb, R.H., Steiger, J.W., and Newman, E.B., 1988b, The response of vegetation to disturbance in Death Valley National Monument, California: U.S. Geological Survey Bulletin 1793, 103 p.

Webb, R.H., Pringle, P.T., and Rink, G.R., 1989, Debris flows from tributaries of the Colorado River, Grand Canyon National Park, Arizona: U.S. Geological Survey Professional Paper 1492, 39 p.

Whipple, K.X., and Dunne, T., 1992, The influence of debris-flow rheology on fan morphology, Owens Valley, California: Geological Society of America Bulletin, v. 104, p. 887-900.

Wohl, E.E., and Pearthree, P.P., 1991, Debris flows as geomorphic agents in the Huachuca Mountains of southeastern Arizona: Geomorphology, v. 4, p. 273292. 
APPENDIX 1. HISTORICAL PHOTOGRAPHS OF LAVA FALLS RAPID AND THE DEBRIS FAN AT THE MOUTH OF PROSPECT CANYON

\begin{tabular}{|c|c|c|c|c|c|c|c|}
\hline Year & Date & $\begin{array}{l}\text { Photo- } \\
\text { grapher }\end{array}$ & $\begin{array}{l}\text { Original } \\
\text { number }\end{array}$ & $\begin{array}{l}\text { Original } \\
\text { source }\end{array}$ & $\begin{array}{l}\text { Stake } \\
\text { number }\end{array}$ & $\begin{array}{l}\text { Side, } \\
\text { direction }\end{array}$ & $\begin{array}{c}\text { Discharge } \\
\left(\mathrm{m}^{3} / \mathrm{s}\right)\end{array}$ \\
\hline \multirow[t]{12}{*}{1872} & Apr 16 & Hillers & 61 & NA & 967 & $\mathrm{~T}, \mathrm{DS}$ & 280 \\
\hline & Apr 16 & Hillers & 62 & NA & 967 & $\mathrm{~T}, \mathrm{DS}$ & 280 \\
\hline & Apr 16 & Hillers & 216 & $\mathrm{HL}$ & $\mathrm{nm}$ & $\mathrm{T}, \mathrm{AC}$ & na \\
\hline & Apr 16 & Hillers & 896 & NA & $2689 a$ & $\mathrm{~T}, \mathrm{AC}$ & na \\
\hline & Apr 19 & Hillers & 597 & NA & 2744 & $\mathrm{R}, \mathrm{DS}$ & 280 \\
\hline & Apr 19 & Hillers & 515 & NA & $\mathrm{nm}$ & $\mathrm{R}, \mathrm{US}$ & 280 \\
\hline & Apr 19 & Hillers & 602 & NA & 2613 & $\mathrm{R}, \mathrm{US}$ & 280 \\
\hline & Apr 19 & Hillers & 616 & NA & 2598 & $\mathrm{R}, \mathrm{US}$ & 280 \\
\hline & Apr 19 & Hillers & 623 & NA & 3005 & $\mathrm{R}, \mathrm{AC}$ & 280 \\
\hline & Apr 19 & Hillers & 693 & NA & $\mathrm{nm}$ & $\mathrm{R}, \mathrm{AC}$ & 280 \\
\hline & Oct & Bell & 14 & $\mathrm{HL}$ & $\mathrm{nm}$ & $\mathrm{T}, \mathrm{AC}$ & na \\
\hline & Oct & Bell & 243 & NA & 2681 & $\mathrm{~T}, \mathrm{AC}$ & na \\
\hline 1890 & Feb 27 & Stanton & 621 & NA & $1510 b$ & L, DS & $230-400$ \\
\hline \multirow[t]{8}{*}{1909} & Nov 10 & Cogswell & 935 & UCB & $\mathrm{nm}$ & $\mathrm{L}, \mathrm{AC}$ & 280 \\
\hline & Nov 10 & Cogswell & 936 & UCB & $\mathrm{nm}$ & L, US & 280 \\
\hline & Nov 10 & Cogswell & 937 & UCB & $\mathrm{nm}$ & L, US & 280 \\
\hline & Nov 10 & Cogswell & 938 & NYPL & $\mathrm{nm}$ & L, US & 280 \\
\hline & Nov 10 & Cogswell & 940 & UCB & 1511 & L, US & 280 \\
\hline & Nov 10 & Cogswell & 941 & UCB & $\mathrm{nm}$ & L, DS & 280 \\
\hline & Nov 10 & Cogswell & 942 & NYPL & $\mathrm{nm}$ & L, US & 280 \\
\hline & Nov 10 & Cogswell & 1161 & NYPL & 2770 & L, US & 280 \\
\hline \multirow[t]{4}{*}{1912} & Jan 1 & Kolb & 631 & NAU & 3052 & $\mathrm{R}, \mathrm{US}$ & $30-90$ \\
\hline & Jan 1 & Kolb & 632 & NAU & 2599 & $\mathrm{R}, \mathrm{DS}$ & $30-90$ \\
\hline & Jan 1 & Kolb & 5795 & NAU & $\mathrm{nm}$ & $\mathrm{R}, \mathrm{AC}$ & $30-90$ \\
\hline & Jan 2 & Kolb & $4-4$ & NAU & 2662 & L, US & $30-90$ \\
\hline \multirow[t]{3}{*}{1923} & Sep 18 & LaRue & 605 & USGS & 1732 & L, US & 260 \\
\hline & Sep 18 & LaRue & 606 & USGS & 2368 & L, US & 260 \\
\hline & Sep 18 & LaRue & 603 & USGS & 2769 & L, DS & 2,970 \\
\hline \multirow[t]{3}{*}{1927} & Aug 2 & Eddy & 92 & $\mathrm{HL}$ & 1512 & $\mathrm{~L}, \mathrm{AC}$ & 510 \\
\hline & Aug 2 & Eddy & 93 & HL & 2771 & L, US & 510 \\
\hline & Aug 2 & Weatherhead & 172.8 & $\mathrm{HL}$ & 2663 & L, DS & 510 \\
\hline 1929 & nd & Scoyen & 6616 & NPS & 967 & $\mathrm{~T}, \mathrm{DS}$ & 570 \\
\hline 1930 & Jul & Fraser & $\begin{array}{c}307 \\
\text { GDCN } 179.1\end{array}$ & $\mathrm{HL}$ & 967 & $\mathrm{~T}, \mathrm{DS}$ & $280-570$ \\
\hline \multirow[t]{3}{*}{1934} & July 31 & Fahrni & $3-254$ & USHS & $2658 b$ & $\mathrm{~L}, \mathrm{AC}$ & 60 \\
\hline & July 31 & Fahrni & $3-255$ & USHS & $2658 c$ & $\mathrm{~L}, \mathrm{AC}$ & 60 \\
\hline & July 31 & Fahrni & $3-258$ & USHS & $2658 a$ & L, DS & 60 \\
\hline 1934 & July 31 & Fahrni & $3-260$ & USHS & 2743 & L, US & 60 \\
\hline \multirow[t]{2}{*}{1936} & Feb 29 & Maxon & v. 83, p. 126 & $\mathrm{HL}$ & $\mathrm{nm}$ & $\mathrm{AR}, \mathrm{AC}$ & nd \\
\hline & Feb 29 & Maxon & v. 83, p. 127 & $\mathrm{HL}$ & $\mathrm{nm}$ & $\mathrm{AR}, \mathrm{DS}$ & $140-280$ \\
\hline \multirow[t]{2}{*}{1937} & Nov 16 & Sharp & nd & OP & 2045 & $\mathrm{~L}, \mathrm{AC}$ & 200 \\
\hline & Nov 16 & Maxon & 275 & HL & $\mathrm{nm}$ & L, US & 200 \\
\hline \multirow[t]{2}{*}{1938} & nd & Inglesby & movie \#7* & USHS & $\mathrm{nm}$ & $\mathrm{R}, \mathrm{AC}$ & $>510$ \\
\hline & Jul 29 & Clover & $2: 14: 14$ & UU & 2838 & L, US & 360 \\
\hline 1939 & Jul 15 & Gibson & movie $†$ & OP & $\mathrm{nm}$ & $L, A C$ & 220 \\
\hline
\end{tabular}




\begin{tabular}{|c|c|c|c|c|c|c|c|}
\hline Year & Date & $\begin{array}{l}\text { Photo- } \\
\text { grapher }\end{array}$ & $\begin{array}{l}\text { Original } \\
\text { number }\end{array}$ & $\begin{array}{l}\text { Original } \\
\text { source }\end{array}$ & $\begin{array}{l}\text { Stake } \\
\text { number }\end{array}$ & $\begin{array}{l}\text { Side, } \\
\text { direction }\end{array}$ & $\begin{array}{l}\text { Discharge } \\
\left(\mathrm{m}^{3} / \mathrm{s}\right)\end{array}$ \\
\hline \multirow[t]{3}{*}{1940} & Aug 17 & Goldwater & CR 24 & $\mathrm{CCP}$ & 2657 & $L, A C$ & 71 \\
\hline & Aug 17 & Goldwater & CR 57 & $\mathrm{CCP}$ & 2742 & L, DS & 71 \\
\hline & Aug 17 & Goldwater & CR 34 & CCP & 2659 & L, UC & 71 \\
\hline \multirow[t]{3}{*}{1941} & May 19 & McKee & 1348 & NAU & $2689 b$ & $\mathrm{~T}, \mathrm{AC}$ & nd \\
\hline & May 19 & McKee & 1349 & NAU & $2689 a$ & $\mathrm{~T}, \mathrm{AC}$ & nd \\
\hline & Jul 27 & Heald & $3: 6: 6$ & UU & 2741 & L, DS & 580 \\
\hline \multirow[t]{3}{*}{1942} & Jul 26 & Wilson & $4: 8: 11$ & UU & $2660 a$ & $\mathrm{~L}, \mathrm{AC}$ & 460 \\
\hline & Jul 26 & Wilson & $4: 6: 8$ & UU & $2660 b$ & $\mathrm{~L}, \mathrm{AC}$ & 460 \\
\hline & Jul 26 & Wilson & $4: 12: 5$ & UU & 2834 & $\vec{L}, \mathrm{AC}$ & 460 \\
\hline \multirow[t]{5}{*}{1947} & Jul 22 & Farquhar & $\begin{array}{c}477 \text { GDCN } \\
179.2 .2\end{array}$ & $\mathrm{HL}$ & $\mathrm{nm}$ & $\mathrm{R}, \mathrm{DS}$ & 690 \\
\hline & Jul 27 & Riffey & $\begin{array}{c}477 \mathrm{GDCN} \\
179.444\end{array}$ & $\mathrm{HL}$ & 1769 & $\mathrm{~L}, \mathrm{AC}$ & 520 \\
\hline & Jul 27 & Marston & $\begin{array}{c}477 \text { GDCN } \\
179.2\end{array}$ & HL & 1770 & $\mathrm{~L}, \mathrm{AC}$ & 520 \\
\hline & Jul 27 & Marston & $\begin{array}{c}477 \text { GDCN } \\
179.12\end{array}$ & HL & 1768 & $L, A C$ & 520 \\
\hline & Jul 27 & Nevills & $5: 12: 1$ & UU & 2661 & $\mathrm{~L}, \mathrm{AC}$ & 520 \\
\hline \multirow[t]{2}{*}{1949} & Jul 27 & Anspach & $\begin{array}{c}497 \text { GDCN } \\
179.8\end{array}$ & $\mathrm{HL}$ & 2004 & $\mathrm{~L}, \mathrm{AC}$ & 580 \\
\hline & Jul 27 & Reilly & L6-35 & OP & 2043 & L, DS & 580 \\
\hline \multirow[t]{5}{*}{1950} & Jun 19 & Belknap & 48826 & NPS & 2772 & L, DS & 1,470 \\
\hline & Jun 19 & Belknap & 48833 & NPS & $\mathrm{nm}$ & $\mathrm{R}, \mathrm{AC}$ & 1,470 \\
\hline & Jun 19 & Belknap & 48839 & NPS & $\mathrm{nm}$ & $\mathrm{R}, \mathrm{AC}$ & 1,470 \\
\hline & Jun 19 & Belknap & 48841 & NPS & 803 & $\mathrm{R}, \mathrm{AC}$ & 1,470 \\
\hline & Jul 25 & Reilly & R01-11 & OP & 2046 & L, US & 470 \\
\hline \multirow[t]{3}{*}{1951} & Jul & Litton & nd & OP & 967 & $\mathrm{~T}, \mathrm{DS}$ & 2,260 \\
\hline & Jul & Litton & nd & OP & 969 & $\mathrm{~T}, \mathrm{DS}$ & 2,260 \\
\hline & Jul & Litton & nd & OP & 2959 & $\mathrm{R}, \mathrm{DS}$ & 2,260 \\
\hline \multirow[t]{3}{*}{1951} & Sep & Eden & 2082 & NPS & 969 & $\mathrm{~T}, \mathrm{DS}$ & $>280$ \\
\hline & Sep & Eden & 2085 & NPS & 967 & $\mathrm{~T}, \mathrm{DS}$ & $>280$ \\
\hline & Sep & Eden & 2087 & NPS & 967 & $\mathrm{~T}, \mathrm{DS}$ & $>280$ \\
\hline \multirow[t]{7}{*}{1952} & Jul & Nichols & nd & OP & 2935 & L, DS & 1,130 \\
\hline & Jul & Nichols & nd & OP & 2957 & L, DS & 1,130 \\
\hline & Jul & Nichols & nd & OP & 2969 & $\mathrm{~L}, \mathrm{AC}$ & 1,130 \\
\hline & Jul & Litton & nd & OP & 967 & $\mathrm{~T}, \mathrm{DS}$ & 1,130 \\
\hline & Jul & Litton & nd & OP & 2968 & $\mathrm{~L}, \mathrm{AC}$ & 1,130 \\
\hline & Oct 22 & Leding & 2359 & NPS & 969 & $\mathrm{~T}, \mathrm{DS}$ & 164 \\
\hline & Oct 22 & Leding & 2360 & NPS & 969 & $\mathrm{~T}, \mathrm{DS}$ & 164 \\
\hline \multirow[t]{2}{*}{1953} & Jul & Beckwith & nd & OP & $2971 a$ & L, US & 708 \\
\hline & Jul & Beckwith & nd & OP & 2971b & L, DS & 708 \\
\hline \multirow[t]{3}{*}{1954} & Jun 14 & Visbak & JV VI 5 & $\mathrm{HL}$ & 2961 & $\mathrm{R}, \mathrm{DS}$ & 360 \\
\hline & Jul & Nichols & nd & OP & 2966 & $\mathrm{R}, \mathrm{DS}$ & $>990$ \\
\hline & Aug 29 & Visbak & nd & HL & $\mathrm{nm}$ & $\mathrm{R}, \mathrm{DS}$ & 133 \\
\hline
\end{tabular}




\section{APPENDIX 1. HISTORICAL PHOTOGRAPHS OF LAVA FALLS RAPID AND THE DEBRIS FAN AT THE MOUTH OF PROSPECT CANYON (contd)}

\begin{tabular}{|c|c|c|c|c|c|c|c|}
\hline Year & Date & $\begin{array}{l}\text { Photo- } \\
\text { grapher }\end{array}$ & $\begin{array}{l}\text { Original } \\
\text { number }\end{array}$ & $\begin{array}{l}\text { Original } \\
\text { source }\end{array}$ & $\begin{array}{l}\text { Stake } \\
\text { number }\end{array}$ & $\begin{array}{l}\text { Side, } \\
\text { direction }\end{array}$ & $\begin{array}{l}\text { Discharge } \\
\left(\mathrm{m}^{3} / \mathrm{s}\right)\end{array}$ \\
\hline \multirow[t]{15}{*}{1955} & Mar 19 & Reilly & L11-13 & OP & $\mathrm{nm}$ & $A R, D S$ & 540 \\
\hline & Mar 19 & Reilly & L11-14 & OP & $\mathrm{nm}$ & $A L, A C$ & 540 \\
\hline & Mar 19 & Reilly & L11-15 & OP & $\mathrm{nm}$ & AR, DS & 540 \\
\hline & Mar 19 & Reilly & L11-16 & OP & $\mathrm{nm}$ & AR, AC & 540 \\
\hline & Mar 21 & Reilly & L12-13 & OP & $\mathrm{nm}$ & AV & 400 \\
\hline & Mar 21 & Reilly & L12-14 & OP & $\mathrm{nm}$ & AR, US & 400 \\
\hline & Mar 21 & Reilly & L12-15 & OP & $\mathrm{nm}$ & AV & 400 \\
\hline & Apr 29 & Beer & nd & OP & 2972 & L, AC & 430 \\
\hline & Apr 29 & Beer & nd & OP & 2934 & L, US & 430 \\
\hline & Apr 29 & Beer & movie§ & OP & $\mathrm{nm}$ & $L, A C$ & 430 \\
\hline & Jul 20 & Beckwith & nd & $\mathrm{HL}$ & $\mathrm{nm}$ & $\mathrm{L}, \mathrm{AC}$ & 209 \\
\hline & Sep 3 & Dudziak & v. 83 , p. 36 & HL & $\mathrm{nm}$ & T, DS & nd \\
\hline & Oct & Hamilton & 8352 & NPS & 969 & T, DS & 114 \\
\hline & Oct & Hamilton & 8353 & NPS & 969 & $\mathrm{~T}, \mathrm{DS}$ & 114 \\
\hline & Oct & Hamilton & 5605 & NPS & 969 & $\mathrm{~T}, \mathrm{DS}$ & 114 \\
\hline \multirow[t]{6}{*}{1956} & Mar 25 & Marston & $\begin{array}{c}563 \mathrm{GDCN} \\
179.8\end{array}$ & $\mathrm{HL}$ & 969 & $\mathrm{~T}, \mathrm{DS}$ & 181 \\
\hline & Mar 25 & Reilly & L19-26 & OP & $\mathrm{nm}$ & AR, DS & 181 \\
\hline & Mar 25 & Reilly & L19-27 & OP & $\mathrm{nm}$ & $A L, A C$ & 181 \\
\hline & Mar 25 & Reilly & L19-28 & OP & $\mathrm{nm}$ & $A L, U S$ & 181 \\
\hline & Mar 25 & Reilly & L19-33 & OP & 967 & $\mathrm{~T}, \mathrm{DS}$ & 181 \\
\hline & Mar 25 & Reilly & L19-34 & OP & 967 & $\mathrm{~T}, \mathrm{DS}$ & 181 \\
\hline \multirow[t]{8}{*}{1956} & Mar 25 & Reilly & L19-35 & OP & 967 & $\mathrm{~T}, \mathrm{DS}$ & 181 \\
\hline & Apr 16 & Reilly & L24-2 & OP & $\mathrm{nm}$ & AR, US & 297 \\
\hline & Apr 16 & Reilly & L24-7 & OP & 969 & $\mathrm{~T}, \mathrm{DS}$ & 297 \\
\hline & Apr 16 & Reilly & G-875 & OP & 969 & T, DS & 297 \\
\hline & Apr 16 & Reilly & G-164 & OP & 967 & $\mathrm{~T}, \mathrm{DS}$ & 297 \\
\hline & Sep 29 & Reilly & L26-14 & OP & $\mathrm{nm}$ & AV & 79 \\
\hline & Sep 29 & Reilly & L26-15 & OP & $\mathrm{nm}$ & $A V$ & 79 \\
\hline & Sep 29 & Reilly & L26-16 & OP & $\mathrm{nm}$ & $\mathrm{AR}, \mathrm{US}$ & 79 \\
\hline \multirow[t]{11}{*}{1957} & Apr 14 & Reilly & L28-29 & OP & $\mathrm{nm}$ & $A L, A C$ & 249 \\
\hline & Apr 14 & Reilly & L28-30 & OP & $\mathrm{nm}$ & $A L, A C$ & 249 \\
\hline & May 4 & Reilly & L29-23 & OP & $\mathrm{nm}$ & AR, DS & 521 \\
\hline & May 4 & Reilly & L29-24 & OP & $\mathrm{nm}$ & $A L, D S$ & 521 \\
\hline & May 4 & Reilly & L29-25 & OP & $\mathrm{nm}$ & $\mathrm{AL}, \mathrm{AC}$ & 521 \\
\hline & May 4 & Reilly & L29-26 & OP & $\mathrm{nm}$ & $\mathrm{AL}, \mathrm{AC}$ & 521 \\
\hline & May 4 & Reilly & L29-27 & OP & $\mathrm{nm}$ & AR, DS & 521 \\
\hline & May 4 & Reilly & L29-28 & OP & $\mathrm{nm}$ & $\mathrm{AR}, \mathrm{AC}$ & 521 \\
\hline & Jul 13 & Nichols & nd & OP & 2932 & L, DS & 1,980 \\
\hline & Jul 13 & Beckwith & II-17 & HL & 1586 & L, DS & 1,980 \\
\hline & Aug 29 & Butchart & nd & HL & $\mathrm{nm}$ & $\mathrm{L}, \mathrm{AC}$ & 589 \\
\hline \multirow[t]{3}{*}{1958} & Apr 20 & Reilly & L37-33 & OP & $\mathrm{nm}$ & $A L, A C$ & 708 \\
\hline & Apr 20 & Reilly & L37-34 & OP & $\mathrm{nm}$ & $A L, A C$ & 708 \\
\hline & May 24 & McCullough & 92.12 .808 & NAU & $\mathrm{nm}$ & $\mathrm{L}, \mathrm{DS}$ & 2,120 \\
\hline
\end{tabular}




\begin{tabular}{|c|c|c|c|c|c|c|c|}
\hline Year & Date & $\begin{array}{l}\text { Photo- } \\
\text { grapher }\end{array}$ & $\begin{array}{l}\text { Original } \\
\text { number }\end{array}$ & $\begin{array}{l}\text { Original } \\
\text { source }\end{array}$ & $\begin{array}{c}\text { Stake } \\
\text { number }\end{array}$ & $\begin{array}{l}\text { Side, } \\
\text { direction }\end{array}$ & $\begin{array}{c}\text { Discharge } \\
\left(\mathrm{m}^{3} / \mathrm{s}\right)\end{array}$ \\
\hline & May 24 & McCullough & & NAU & $\mathrm{nm}$ & L, DS & 2,120 \\
\hline & Jun 1 & Reilly & L40-8 & OP & 969 & $\mathrm{~T}, \mathrm{DS}$ & 3,000 \\
\hline & Jun 1 & Reilly & L40-10 & OP & 969 & $\mathrm{~T}, \mathrm{DS}$ & 3,000 \\
\hline & Jun 1 & Reilly & L40-13 & OP & $\mathrm{nm}$ & AV & 3,000 \\
\hline & Jun 1 & Reilly & L40-17 & OP & $\mathrm{nm}$ & AR, DS & 3,000 \\
\hline & Jun 1 & Reilly & L40-20 & OP & $\mathrm{nm}$ & $\mathrm{AR}, \mathrm{DS}$ & 3,000 \\
\hline & Jul 20 & Staveley & nd & $\mathrm{HL}$ & 2002 & L, DS & 218 \\
\hline & Oct 4 & Reilly & L41-18 & OP & $\mathrm{nm}$ & $A L, D S$ & 187 \\
\hline & Oct 4 & Reilly & L41-19 & OP & $\mathrm{nm}$ & $A L, D S$ & 187 \\
\hline & Oct 4 & Reilly & L41-20 & OP & $\mathrm{nm}$ & $A R, U S$ & 187 \\
\hline & Oct 4 & Reilly & G-407 & OP & $\mathrm{nm}$ & $\mathrm{AR}, \mathrm{US}$ & 187 \\
\hline & Oct 4 & Reilly & G-415 & OP & $\mathrm{nm}$ & $A L, D S$ & 187 \\
\hline & Oct 4 & Reilly & G-417 & OP & $\mathrm{nm}$ & $A R, U S$ & 187 \\
\hline 1959 & Aug 21 & Dodge & 8346 & NPS & 967 & $\mathrm{~T}, \mathrm{DS}$ & 224 \\
\hline \multirow[t]{7}{*}{1960} & Jun 23 & Marston & $\begin{array}{c}606 \mathrm{GDCN} \\
179.2 .19\end{array}$ & HL & 1585 & L, DS & 1,140 \\
\hline & Jun 23 & Marston & 48832 & NPS & 1587b & L, DS & 1,140 \\
\hline & Jun 23 & Marston & $\begin{array}{l}606 \mathrm{GDCN} \\
179.18 .10\end{array}$ & $\mathrm{HL}$ & 1588 & L, DS & 1,140 \\
\hline & Jun 23 & Marston & $\begin{array}{c}606 \mathrm{GDCN} \\
179.2 .14\end{array}$ & HL & $1587 a$ & L, DS & 1,140 \\
\hline & Oct 2 & Reilly & L48-32 & OP & $\mathrm{nm}$ & $\mathrm{AR}, \mathrm{AC}$ & 125 \\
\hline & Oct 2 & Reilly & L48-33 & OP & $\mathrm{nm}$ & $A L, A C$ & 125 \\
\hline & Oct 2 & Reilly & L48-34 & OP & $\mathrm{nm}$ & $A R, A C$ & 125 \\
\hline 1961 & Oct & Jones & 46 & OP & 2967 & $\mathrm{~L}, \mathrm{AC}$ & 57 \\
\hline \multirow[t]{8}{*}{1962} & May 24 & McCullough & 217 & NAU & 2964b & L, DS & 1,440 \\
\hline & May 24 & McCullough & nd & NAU & $\mathrm{nm}$ & $\vec{R}, \mathrm{US}$ & 1,440 \\
\hline & Jul 10 & Reilly & L58-3 & OP & 2003 & $\mathrm{~L}, \mathrm{AC}$ & 1,130 \\
\hline & Jul 10 & Reilly & L58-4 & OP & 2835 & L, DS & 1,130 \\
\hline & Nov 3 & Reilly & L61-2 & OP & $\mathrm{nm}$ & $\mathrm{AR}, \mathrm{DS}$ & 225 \\
\hline & Nov 3 & Reilly & L61-4 & OP & $\mathrm{nm}$ & $A L, A C$ & 225 \\
\hline & Nov 3 & Reilly & L61-5 & OP & $\mathrm{nm}$ & $A L, U S$ & 225 \\
\hline & Nov 4 & Reilly & R74-8 & OP & $\mathrm{nm}$ & $A L, A C$ & 225 \\
\hline \multirow[t]{8}{*}{1963} & May & Wieland & 24 & $\mathrm{HL}$ & 969 & $\mathrm{~T}, \mathrm{DS}$ & 37 \\
\hline & Aug 22 & Belknap & 48822 & NPS & $\mathrm{nm}$ & $A L, U S$ & 57 \\
\hline & Aug 22 & Belknap & 48823 & NPS & $\mathrm{nm}$ & $A L, U S$ & 57 \\
\hline & Aug 24 & Belknap & 48858 & NPS & 2746 & $\mathrm{R}, \mathrm{AC}$ & 57 \\
\hline & Aug 24 & Belknap & 48865 & NPS & 2746 & $\mathrm{R}, \mathrm{AC}$ & 57 \\
\hline & Aug 24 & Belknap & 48824 & NPS & 969 & $\mathrm{R}, \mathrm{DS}$ & 57 \\
\hline & Aug 25 & Belknap & 48866 & NPS & 803 & $\mathrm{R}, \mathrm{AC}$ & 57 \\
\hline & Sep 25 & nd & $\begin{array}{c}63-9-25 \\
\text { GDCN 179-25 }\end{array}$ & $\mathrm{HL}$ & 1589 & $\mathrm{R}, \mathrm{DS}$ & 35 \\
\hline
\end{tabular}




\begin{tabular}{|c|c|c|c|c|c|c|c|}
\hline Year & Date & $\begin{array}{l}\text { Photo- } \\
\text { grapher }\end{array}$ & $\begin{array}{l}\text { Original } \\
\text { number }\end{array}$ & $\begin{array}{l}\text { Original } \\
\text { source }\end{array}$ & $\begin{array}{l}\text { Stake } \\
\text { number }\end{array}$ & $\begin{array}{l}\text { Side, } \\
\text { direction }\end{array}$ & $\begin{array}{l}\text { Discharge } \\
\left(\mathrm{m}^{3} / \mathrm{s}\right)\end{array}$ \\
\hline & Sep 25 & nd & $\begin{array}{c}\text { 63-9-25 } \\
\text { GDCN 179-28 }\end{array}$ & $\mathrm{HL}$ & 2005 & $R$, US & 35 \\
\hline \multirow[t]{6}{*}{1964} & Apr 6 & Visbak & 34 & HL & $\mathrm{nm}$ & AV & 40 \\
\hline & Apr 6 & Visbak & 36 & $H L$ & $\mathrm{~nm}$ & AR, DS & 405 \\
\hline & May 12 & Reilly & L70-32 & OP & 2044 & $\mathrm{~L}, \mathrm{AC}$ & 348 \\
\hline & May 20 & Reilly & L71-26 & OP & $\mathrm{nm}$ & $A L, U S$ & 37 \\
\hline & May 20 & Reilly & L71-28 & OP & $\mathrm{nm}$ & AR, DS & 37 \\
\hline & May 20 & Reilly & L71-29 & OP & $\mathrm{nm}$ & $A R$, US & 37 \\
\hline \multirow[t]{5}{*}{1964} & May 20 & Reilly & L71-30 & OP & $\mathrm{nm}$ & AR, US & 37 \\
\hline & May 20 & Reilly & L71-32 & OP & $\mathrm{nm}$ & $A L, U S$ & 37 \\
\hline & May 20 & Reilly & L71-33 & OP & $\mathrm{nm}$ & $\mathrm{AL}, \mathrm{AC}$ & 37 \\
\hline & May 20 & Reilly & L71-34 & OP & $\mathrm{nm}$ & $\mathrm{AL}, \mathrm{AC}$ & 37 \\
\hline & May 20 & Reilly & L71-36 & OP & $\mathrm{nm}$ & AR, US & 37 \\
\hline \multirow[t]{8}{*}{1965} & Feb 21 & Visbak & 16 & HL & 1592 & $\mathrm{R}, \mathrm{DS}$ & 200 \\
\hline & Feb 21 & Visbak & 24 & HL & 3050 & $R$, US & 200 \\
\hline & Feb 21 & Visbak & 14 & HL & 967 & $\mathrm{~T}, \mathrm{DS}$ & 200 \\
\hline & Feb 22 & Visbak & 36 & $\mathrm{HL}$ & 969 & $\mathrm{R}, \mathrm{DS}$ & 200 \\
\hline & May 18 & USGS & $83^{* *}$ & USGS & $\mathrm{nm}$ & AV & 792 \\
\hline & May 18 & USGS & $84^{* *}$ & USGS & $\mathrm{nm}$ & AV & 792 \\
\hline & May 21 & Harris & 2 & OP & 3010 & L, DS & 792 \\
\hline & May 21 & Harris & 3 & OP & 2836 & $\mathrm{~L}, \mathrm{AC}$ & 792 \\
\hline \multirow[t]{2}{*}{1966} & May 19 & Hertzog & $6525 \mathrm{NA}$ & BOR & 969 & $\mathrm{~T}, \mathrm{DS}$ & 340 \\
\hline & Jul & Belknap & $83(157)$ & NPS & $\mathrm{nm}$ & R, DS & 200 \\
\hline \multirow[t]{3}{*}{1967} & Apr 30 & Harris & $\begin{array}{l}P 557-400- \\
896\end{array}$ & OP & 2739 & $L, A C$ & 280 \\
\hline & Aug & Luepke & nd & OP & $2964 b$ & L, DS & nd \\
\hline & Aug & Luepke & nd & OP & $2964 b$ & L, DS & nd \\
\hline \multirow[t]{6}{*}{1968} & May 12 & McCullough & nd & NAU & $2964 b$ & L, DS & 340 \\
\hline & May 12 & McCullough & nd & NAU & $\mathrm{nm}$ & $R$, US & 340 \\
\hline & Sep 8 & Billingsley & 195 & OP & $\mathrm{nm}$ & L, US & $140-280$ \\
\hline & Sep 26 & Stephens & $515^{\#}$ & OP & $\mathrm{nm}$ & $R$, US & 280 \\
\hline & Sep 26 & Stephens & 693\# & OP & $\mathrm{nm}$ & $\mathrm{R}, \mathrm{AC}$ & 280 \\
\hline & Sep 26 & Stephens & $597 \#$ & OP & 2744 & $R, D S$ & 280 \\
\hline \multirow[t]{3}{*}{1969} & Jul & Harris & 4 & OP & $2740 b$ & $L, A C$ & $570-850$ \\
\hline & Jul & Harris & 1 & OP & $2740 a$ & $L, A C$ & $570-850$ \\
\hline & Sep 14 & Marston & $\begin{array}{c}69-9-14 \\
\text { GDCN 179-5 }\end{array}$ & HL & $\mathrm{nm}$ & L, DS & 280 \\
\hline 1970 & Oct & Mooz & 16 & $\mathrm{HL}$ & $\mathrm{nm}$ & L, US & $140-370$ \\
\hline \multirow[t]{3}{*}{1971} & Apr 25 & Billinsley & nd & OP & $\mathrm{nm}$ & R, DS & 140 \\
\hline & Jun 12 & Billingsley & nd & OP & $\mathrm{nm}$ & L, US & $140-280$ \\
\hline & Jul 9 & Billingsley & nd & OP & $\mathrm{nm}$ & $\mathrm{R}, \mathrm{DS}$ & 140 \\
\hline \multirow[t]{3}{*}{1972} & Jun 12 & Billingsley & nd & OP & $\mathrm{nm}$ & $R$, US & nd \\
\hline & Aug 5 & Billingsley & nd & OP & $\mathrm{nm}$ & $\mathrm{R}, \mathrm{US}$ & 140 \\
\hline & Sep 28 & Billingsley & nd & OP & $\mathrm{nm}$ & $R$, US & 140 \\
\hline
\end{tabular}


APPENDIX 1. HISTORICAL PHOTOGRAPHS OF LAVA FALLS RAPID AND

THE DEBRIS FAN AT THE MOUTH OF PROSPECT CANYON (contd)

\begin{tabular}{|c|c|c|c|c|c|c|c|}
\hline Year & Date & $\begin{array}{l}\text { Photo- } \\
\text { grapher }\end{array}$ & $\begin{array}{l}\text { Original } \\
\text { number }\end{array}$ & $\begin{array}{l}\text { Original } \\
\text { source }\end{array}$ & $\begin{array}{c}\text { Stake } \\
\text { number }\end{array}$ & $\begin{array}{l}\text { Side, } \\
\text { direction }\end{array}$ & $\begin{array}{l}\text { Discharge } \\
\left(\mathrm{m}^{3} / \mathrm{s}\right)\end{array}$ \\
\hline & nd & Litton & nd & OP & 2677 & $\mathrm{R}, \mathrm{AC}$ & $280-424$ \\
\hline \multirow[t]{2}{*}{1972} & nd & Litton & nd & OP & 2962 & $\mathrm{R}, \mathrm{US}$ & $280-424$ \\
\hline & nd & Litton & nd & OP & 2963 & $\mathrm{R}, \mathrm{US}$ & $280-424$ \\
\hline \multirow[t]{4}{*}{1973} & May 18 & McCullough & 191 & NAU & 969 & $\mathrm{~T}, \mathrm{DS}$ & nd \\
\hline & Jun & Billingsley & nd & OP & $\mathrm{nm}$ & $\mathrm{R}, \mathrm{AC}$ & nd \\
\hline & Jun 19 & USGS & $516^{\star \star}$ & USGS & $\mathrm{nm}$ & AV & 390 \\
\hline & Jun 19 & USGS & $517^{\star \star}$ & USGS & $\mathrm{nm}$ & AV & 390 \\
\hline \multirow[t]{4}{*}{1974} & Jun & Billingsley & nd & OP & $\mathrm{nm}$ & $\mathrm{R}, \mathrm{AC}$ & nd \\
\hline & Aug & Billingsley & nd & OP & $\mathrm{nm}$ & $\mathrm{R}, \mathrm{AC}$ & nd \\
\hline & Aug & Billingsley & nd & OP & $\mathrm{nm}$ & $\mathrm{R}, \mathrm{AC}$ & nd \\
\hline & Sep 20 & Billingsley & nd & OP & $\mathrm{nm}$ & $\mathrm{R}, \mathrm{AC}$ & nd \\
\hline \multirow[t]{2}{*}{1975} & May & Billingsley & nd & OP & $\mathrm{nm}$ & $\mathrm{R}, \mathrm{AC}$ & 140 \\
\hline & Sep & Billingsley & nd & OP & $\mathrm{nm}$ & $\mathrm{R}, \mathrm{AC}$ & 140 \\
\hline \multirow[t]{2}{*}{1976} & Apr 29 & Billingsley & nd & OP & $\mathrm{nm}$ & $\mathrm{R}, \mathrm{AC}$ & 140 \\
\hline & Sep 26 & Turner & 803 & OP & 803 & $\mathrm{R}, \mathrm{AC}$ & 99 \\
\hline \multirow[t]{3}{*}{1977} & nd & Brown & nd & OP & 2837 & $\mathrm{R}, \mathrm{US}$ & $<85$ \\
\hline & nd & Brown & nd & OP & 2907 & $\mathrm{R}, \mathrm{US}$ & $<85$ \\
\hline & nd & Brown & nd & OP & $\mathrm{nm}$ & $\mathrm{R}, \mathrm{US}$ & $<85$ \\
\hline \multirow[t]{2}{*}{1979} & Jun 10 & Turner & 967 & OP & 967 & $\mathrm{~T}, \mathrm{DS}$ & 230 \\
\hline & Jun 10 & Turner & 969 & OP & 969 & $\mathrm{~T}, \mathrm{DS}$ & 230 \\
\hline 1982 & Jun 8 & BOR & $2-209$ & BOR & $\mathrm{nm}$ & AV & 200 \\
\hline 1983 & Oct 31 & Turner & 803 & OP & 803 & $\mathrm{R}, \mathrm{AC}$ & 765 \\
\hline \multirow[t]{2}{*}{1984} & Oct 23 & BOR & $6-48^{* *}$ & BOR & $\mathrm{nm}$ & AV & 140 \\
\hline & Oct 23 & BOR & $6-49^{* *}$ & BOR & $\mathrm{nm}$ & AV & 140 \\
\hline \multirow[t]{2}{*}{1994} & Jun 1 & BOR & $102-9$ & BOR & $\mathrm{nm}$ & AV & 234 \\
\hline & Jun 1 & BOR & $102-10$ & BOR & $\mathrm{nm}$ & AV & 234 \\
\hline 1995 & May 30 & BOR & $102-9$ & BOR & $\mathrm{nm}$ & AV & 263 \\
\hline 1995 & May 30 & BOR & $102-10$ & BOR & $\mathrm{nm}$ & AV & 263 \\
\hline
\end{tabular}


APPENDIX 1. HISTORICAL PHOTOGRAPHS OF LAVA FALLS RAPID AND

THE DEBRIS FAN AT THE MOUTH OF PROSPECT CANYON (contd)

\begin{tabular}{llllccc}
\hline & Photo- & Original & Original \\
Yumber & Date & source & $\begin{array}{c}\text { Stake } \\
\text { number }\end{array}$ & $\begin{array}{c}\text { Side, } \\
\text { direction }\end{array}$ & $\begin{array}{c}\text { Discharge } \\
\left(\mathrm{m}^{3} / \mathrm{s}\right)\end{array}$ \\
\hline
\end{tabular}

Notes: (BOR), Bureau of Reclamation; (CCP), Center for Creative Photography; (HL), the Huntington Library; (NA), the National Archives; (NAU), Special Collections, Northern Arizona University; (NPS), Grand Canyon National Park; (NYPL), New York Public Library; (OP), original photographer; (UCB), Bancroft Library, University of California at Berkeley; (USGS), the U.S. Geological Survey Photographic Library; (USHS), Utah State Historical Society; (UU), Special Collections, University of Utah. Stake number refers to the permanent file number in the repeat photography collection at the Desert Laboratory in Tucson, Arizona. (AV), vertical aerial photography; (AL), photograph is an oblique aerial taken from the left side of the river; (AR), photograph is an oblique aerial taken from the right side of the river; $(T)$, photograph was shot from Toroweap overlook; (L), photograph was shot from river left; $(R)$, photograph was shot from riverright; (US), upstream view; (DS), downstream view; (AC), view across the river; (UC), view looking up the tributary channel or away from the river; (nd), no data; $(\mathrm{nm})$, the photograph was analyzed but not matched; (na), not applicable. For photographs taken before 1921, the discharge is estimated from known stagedischarge relations. In particular, see Kieffer (1988) for general stage-discharge relations for the rapid between 142 and 2,610 m3/s. For photographs taken between 1921 and 1963, discharge is estimated from daily discharge records of the previous day for the Colorado River near Grand Canyon. For unknown dates and after 1963, discharge is estimated from known stage-discharge relations. These estimates are accurate to $\pm 30 \mathrm{~m}^{3} / \mathrm{s}$.

"The movie, titled "Hiking to Lava Falls," was shot by Dr. Inglesby in 1938 (Utah State Historical Society). The movie shows panning shots of the rapids and closeups of the waves.

tThe movie was shot by Bill Gibson on the Harris-Loper river trip of July 1939.

$\S$ The movie was shot by John Daggett and Bill Beer in April 1955.

\#The photographs are matches of the Hillers' views of the same number; see Stephens and Shoemaker (1987).

**These vertical aerial photographs are stereo pairs. 


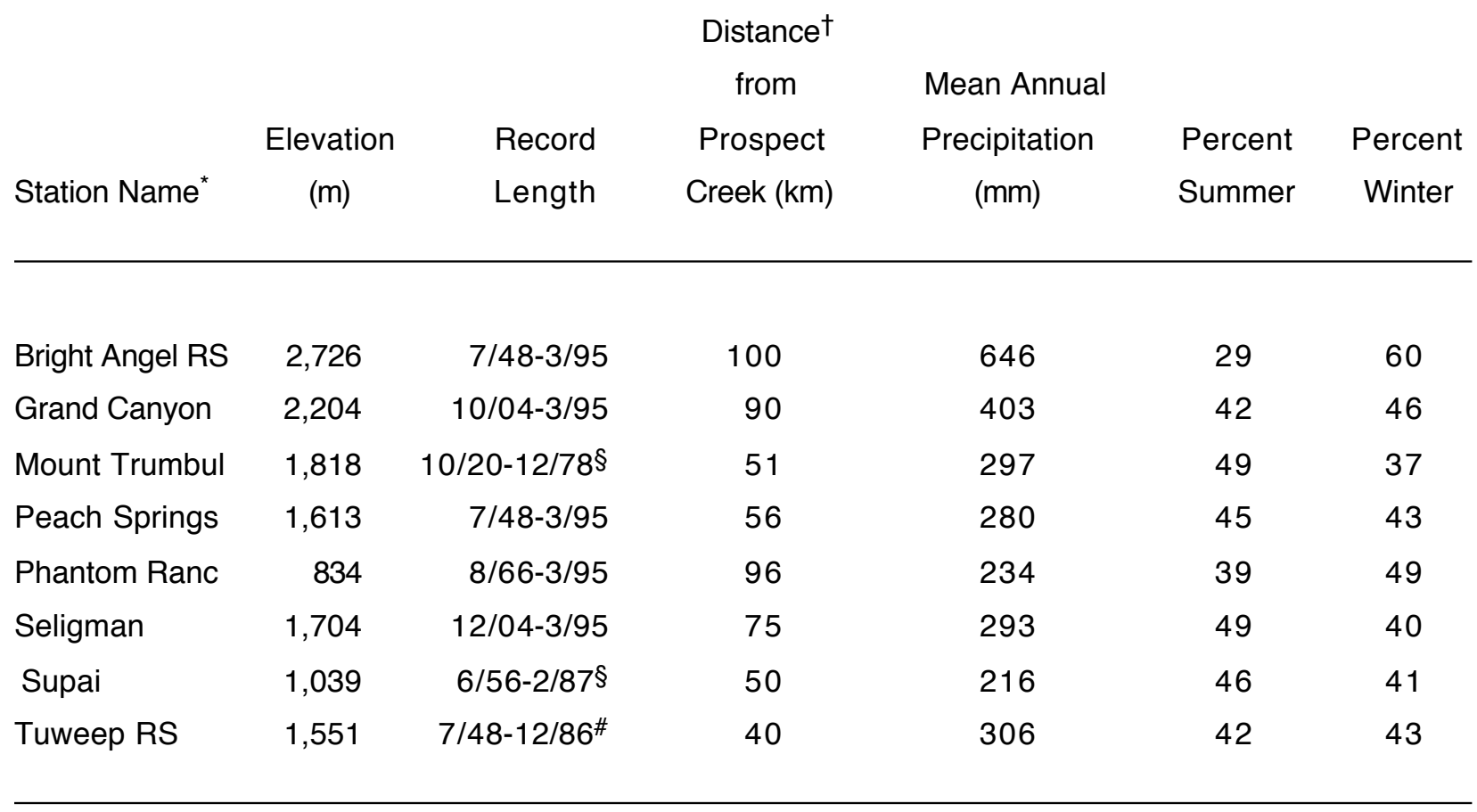

Notes:

* All stations are in Arizona.

tDistance is to the centroid of the Prospect Creek drainage basin.

$\S$ Station discontinued.

\#In 1986, Tuweep Ranger Station was discontinued as a cooperative observer station, which records rainfall in 0.01 in. accuracy and reports in increments of daily rainfall. A tipping-bucket recording rain gage, which records rainfall in 0.10 in. increments and reports hourly as well as daily rainfall (e.g., U.S. Department of Commerce, 1966), remains in operation. 
APPENDIX 3. DAILY PRECIPITATION NEAR PROSPECT CANYON DURING KNOWN OR PROBABLE DATES OF PROSPECT CANYON DEBRIS FLOWS AND FLOODS

PRECIPITATION (mm)

\begin{tabular}{|c|c|c|c|c|c|c|c|}
\hline \multirow[b]{2}{*}{ Climate Station } & \multirow[b]{2}{*}{3} & \multicolumn{4}{|c|}{ DATE IN SEPTEMBER 1939* } & \multicolumn{2}{|c|}{$\begin{array}{l}\text { RECURRENCE } \\
\text { INTERVAL (yrs) }\end{array}$} \\
\hline & & 4 & 5 & 6 & Total & 1-Dayt & Storm§ \\
\hline Seligman & 10 & 39 & 38 & 25 & 112 & 4 & 53 \\
\hline Mount Trumbull & 0 & 33 & 9 & 52 & 94 & 15 & 20 \\
\hline Grand Canyon & 0 & 24 & 42 & 32 & 98 & 7 & 158 \\
\hline Bright Angel RS\# & 0 & 41 & 69 & 39 & 149 & 18 & 81 \\
\hline Climate Station & 10 & 11 & 12 & 13 & Total & 1-Day† & Storm§ \\
\hline Seligman & 0 & 0 & 43 & 12 & 55 & 5 & 4 \\
\hline Mount Trumbull & 9 & 42 & 47 & 0 & 89 & 7 & 33 \\
\hline Grand Canyon & 23 & 25 & 13 & 12 & 73 & $<1$ & 9 \\
\hline \multirow[t]{2}{*}{ Bright Angel RS\# } & 21 & 21 & 33 & 26 & 101 & 2 & 18 \\
\hline & & \multicolumn{6}{|c|}{ DATE IN JULY 1954} \\
\hline Climate Station & & & 24 & 25 & Total & 1-Dayt & Storm§ \\
\hline Seligman & & & 0 & 2 & 2 & $<1$ & na \\
\hline Peach Springs & & & 0 & 3 & 3 & $<1$ & na \\
\hline Tuweep RS & & & 25 & 0 & 25 & 1 & na \\
\hline Mount Trumbull & & & 25 & 6 & 31 & $<1$ & $<1$ \\
\hline Grand Canyon & & & 27 & 0 & 27 & 1 & na \\
\hline \multirow[t]{2}{*}{ Bright Angel RS } & & & 0 & 27 & 27 & $<1$ & na \\
\hline & & \multicolumn{6}{|c|}{ DATE IN JULY 1955} \\
\hline Climate Station & & & 24 & 25 & Total & 1-Day† & Storm§ \\
\hline Seligman & & & 3 & 6 & 9 & $<1$ & $<1$ \\
\hline Peach Springs & & & 26 & 0 & 26 & 1 & na \\
\hline Tuweep RS & & & 10 & 11 & 21 & $<1$ & 1 \\
\hline Mount Trumbull & & & 111 & 1 & 112 & 100 & 100 \\
\hline Grand Canyon & & & 7 & 15 & 22 & $<1$ & $<1$ \\
\hline Bright Angel RS & & & 15 & 8 & 23 & $<1$ & $<1$ \\
\hline
\end{tabular}


APPENDIX 3. DAILY PRECIPITATION NEAR PROSPECT CANYON DURING KNOWN OR PROBABLE DATES OF PROSPECT CANYON DEBRIS FLOWS AND FLOODS (continued)

PRECIPITATION (mm)

\begin{tabular}{|c|c|c|c|c|c|c|c|}
\hline \multirow[b]{3}{*}{ Climate Station } & & \multirow{2}{*}{\multicolumn{3}{|c|}{ DATE IN JULY 1956}} & \multicolumn{3}{|c|}{ RECURRENCE } \\
\hline & & & & & \multicolumn{2}{|c|}{$\begin{array}{l}\text { INTERVAL (yrs) } \\
\text { Total }\end{array}$} & \multirow[b]{2}{*}{ Storm§ } \\
\hline & & 29 & 30 & 31 & Total & 1-Dayt & \\
\hline Seligman & & 0 & 0 & 37 & 37 & 3 & na \\
\hline Peach Springs & & 0 & 4 & 0 & 4 & 4 & na \\
\hline Tuweep RS & & 13 & 1 & 0 & 14 & $<1$ & $<1$ \\
\hline Mount Trumbull & & 10 & 8 & 0 & 18 & $<1$ & $<1$ \\
\hline Supai & & 0 & 0 & 12 & 12 & $<1$ & na \\
\hline Grand Canyon & & 0 & 9 & 6 & 15 & $<1$ & $<1$ \\
\hline \multirow[t]{2}{*}{ Bright Angel RS } & & 0 & 0 & 0 & 0 & na & na \\
\hline & \multicolumn{4}{|c|}{ DATE IN SEPTEMBER $1963^{* \star}$} & & & \\
\hline Climate Station & $16-17$ & 18 & 19 & 20 & Total & 1-Dayt & Storm§ \\
\hline Seligman & 0 & 19 & 0 & 0 & 19 & $<1$ & na \\
\hline Peach Springs & 0 & 21 & 0 & 0 & 21 & $<1$ & na \\
\hline Tuweep RS & 0 & 0 & 0 & 19 & 19 & $<1$ & na \\
\hline Mount Trumbull & 23 & 0 & 0 & 0 & 23 & $<1$ & $<1$ \\
\hline Supai & 0 & 12 & 0 & 0 & 12 & $<1$ & na \\
\hline Grand Canyon & 0 & 9 & 0 & 0 & 9 & $<1$ & na \\
\hline \multirow[t]{2}{*}{ Bright Angel RS } & 0 & 22 & 0 & 0 & 22 & $<1$ & na \\
\hline & & \multicolumn{3}{|c|}{ DATE IN DECEMBER 1966} & & & \\
\hline Climate Station & $3-4$ & 5 & 6 & 7 & Total & 1-Day ${ }^{\dagger}$ & Storm§ \\
\hline Seligman & nd & 27 & 8 & 7 & 42 & 2 & 5 \\
\hline Peach Springs & 9 & 16 & 11 & 14 & 50 & $<1$ & 14 \\
\hline Tuweep RSt† & 25 & 35 & 91 & 2 & 154 & 63 & 63 \\
\hline Mount Trumbull & 17 & nd & 38 & 19 & 74 & 34 & 21 \\
\hline Grand Canyon & 37 & 43 & 26 & 13 & 111 & 16 & 160 \\
\hline Phantom Ranch & 27 & 9 & 8 & 53 & 97 & 4 & 11 \\
\hline Bright Angel RS & - & - & - & - & 280-305 §§ & na & 57 \\
\hline
\end{tabular}


APPENDIX 3. DAILY PRECIPITATION NEAR PROSPECT CANYON DURING KNOWN OR PROBABLE DATES OF PROSPECT CANYON DEBRIS FLOWS AND FLOODS (continued)

PRECIPITATION (mm)

\begin{tabular}{|c|c|c|c|c|c|c|}
\hline \multirow[b]{2}{*}{ Climate Station } & \multicolumn{3}{|c|}{ DATE IN FEBRUARY 1993} & \multirow[b]{2}{*}{ Total } & \multicolumn{2}{|c|}{$\begin{array}{l}\text { RECURRENCE } \\
\text { INTERVAL (yrs) }\end{array}$} \\
\hline & 8 & 9 & 10 & & 1-Day ${ }^{\dagger}$ & Storm§ \\
\hline Seligman & 24 & 24 & 6 & 54 & 2 & 10 \\
\hline Peach Springs & 14 & 42 & 0 & 58 & 32 & 32 \\
\hline Grand Canyon & 12 & 10 & 1 & 23 & $<1$ & $<1$ \\
\hline Phantom Ranch & 7 & 4 & 0 & 11 & $<1$ & $<1$ \\
\hline Bright Angel RS & nd & 24 & 23 & 47 & $<1$ & $<1$ \\
\hline \multirow[t]{2}{*}{ Tuweep RS } & 25 & 0 & 0 & 25 & 2 & na \\
\hline & \multicolumn{3}{|c|}{$\begin{array}{lcr}\text { DATE IN MARCH } 1995 \\
4 & 5\end{array}$} & & & \\
\hline Climate Station & 4 & 5 & 6 & Total & 1-Day ${ }^{\dagger}$ & Storm§ \\
\hline Seligman & 0 & 0 & 13 & 13 & $<1$ & na \\
\hline Peach Springs & 0 & 19 & 0 & 19 & 1 & na \\
\hline Grand Canyon & 5 & 24 & 37 & 66 & 7 & 3 \\
\hline Tuweep RS & 0 & 0 & 43 & 43 & 5 & na \\
\hline Bright Angel RS & 18 & 48 & 78 & 144 & 4 & 4 \\
\hline
\end{tabular}

Notes: Data on the climate stations are given in Appendix 2.

na -- not applicable.

${ }^{*}$ The precipitation is associated with an unnamed tropical cyclone (Smith, 1986).

tRecurrence interval of 1-day storms is for summer (Jul-Oct) or winter (Nov-March) months.

§Recurrence interval for storms is for total rainfall on consecutive days for summer (Jul-Oct) or winter (NovMarch) months.

\#From Gatewood and others (1946).

${ }^{\star *}$ The precipitation was probably related to Tropical Storm Katherine (Smith, 1986).

t†From U.S. Department of Commerce (1966).

$\S \S C$ Coley and others (1977) estimated this value from total precipitation at another station. Using multiple regression on 9 independent December storms recorded at this station and Grand Canyon and Tuweep $\mathrm{RS}$, we estimated a total storm precipitation of $234 \mathrm{~mm}$, which has the same recurrence interval. 
APPENDIX 4. SOURCE AND SIZE OF BOULDERS TRANSPORTED

BY DEBRIS FLOWS IN PROSPECT CANYON.

\begin{tabular}{|c|c|c|c|c|c|c|c|}
\hline \multirow{2}{*}{$\begin{array}{l}\text { Type of } \\
\text { deposit }\end{array}$} & \multirow{2}{*}{$\begin{array}{c}\text { Source } \\
\text { of } \\
\text { boulder }\end{array}$} & \multicolumn{3}{|c|}{ DIAMETER (m) } & \multirow[b]{2}{*}{ Shape } & \multirow{2}{*}{$\begin{array}{c}\text { Volume } \\
\qquad\left(\mathrm{m}^{3}\right)\end{array}$} & \multirow{2}{*}{$\begin{array}{c}\text { Weigh } \\
\text { (Mg) }\end{array}$} \\
\hline & & a-axis & b-axis & c-axis & & & \\
\hline AD 1434 & $\mathrm{~B}$ & 3.7 & 2.7 & 2.4 & E & 13 & 34 \\
\hline debris & B & 2.3 & 2.0 & 1.7 & E & 4.1 & 11 \\
\hline flow & B & 3.3 & 1.6 & 1.2 & E & 3.3 & 9 \\
\hline \multirow[t]{7}{*}{ (tif) } & $B$ & 2.6 & 1.5 & 1.3 & $\mathrm{E}$ & 2.7 & 7.2 \\
\hline & $\mathrm{B}$ & 1.9 & 1.4 & 1.3 & $\mathrm{E}$ & 1.8 & 4.9 \\
\hline & SU & 2.2 & 1.5 & 1.0 & $E$ & 1.7 & 4.6 \\
\hline & B & 2.0 & 1.0 & 0.8 & $E$ & 0.8 & 2.3 \\
\hline & B & 1.5 & 1.0 & 1.0 & $E$ & 0.8 & 2.1 \\
\hline & $B$ & 1.0 & 1.0 & 1.0 & $E$ & 0.5 & 1.4 \\
\hline & RW & 1.0 & 0.9 & 0.8 & $E$ & 0.4 & 1.0 \\
\hline AD 1939 & $B$ & 3.3 & 2.6 & 2.5 & $E$ & 11.2 & 30 \\
\hline debris & $B$ & 3.2 & 2.7 & 1.9 & $E$ & 8.6 & 23 \\
\hline flow & W & 2.9 & 2.3 & 1.8 & $E$ & 6.3 & 16 \\
\hline \multirow[t]{7}{*}{ (tig) } & W & 3.6 & 1.5 & 1.4 & $E$ & 3.9 & 10 \\
\hline & RW & 2.3 & 2.0 & 1.6 & $E$ & 3.9 & 10 \\
\hline & $\mathrm{B}$ & 2.4 & 2.0 & 1.6 & $E$ & 3.0 & 8.1 \\
\hline & $B$ & 1.8 & 1.8 & 1.6 & E & 2.7 & 7.3 \\
\hline & RW & 1.8 & 1.3 & 1.0 & $\mathrm{E}$ & 1.2 & 3.3 \\
\hline & $\mathrm{B}$ & 1.6 & 1.2 & 1.2 & $E$ & 1.2 & 3.3 \\
\hline & B & 1.7 & 1.3 & 1.0 & $E$ & 1.2 & 3.2 \\
\hline AD 1995 & $\mathrm{~B}$ & 1.7 & 1.1 & 0.9 & EC & 1.4 & 3.7 \\
\hline debris & B & 1.3 & 1.1 & 0.9 & $\mathrm{R}$ & 1.3 & 3.5 \\
\hline flow & B & 1.6 & 1.6 & 0.6 & EC & 1.2 & 3.2 \\
\hline \multirow[t]{7}{*}{ (tij) } & W & 2.4 & 1.1 & 0.8 & $E$ & 1.1 & 2.8 \\
\hline & B & 1.8 & 1.1 & 0.8 & $\mathrm{E}$ & 0.8 & 2.3 \\
\hline & $\mathrm{M}$ & 1.4 & 0.8 & 0.7 & $\mathrm{R}$ & 0.8 & 2.0 \\
\hline & B & 1.5 & 0.8 & 0.5 & $\mathrm{R}$ & 0.6 & 1.6 \\
\hline & B & 1.3 & 1.1 & 0.8 & $\mathrm{~T}$ & 0.6 & 1.5 \\
\hline & $B$ & 1.3 & 0.9 & 0.9 & $E$ & 0.6 & 1.5 \\
\hline & B & 1.0 & 0.9 & 0.7 & $\mathrm{R}$ & 0.6 & 1.5 \\
\hline
\end{tabular}


APPENDIX 4. SOURCE AND SIZE OF BOULDERS TRANSPORTED

BY DEBRIS FLOWS IN PROSPECT CANYON.

\begin{tabular}{lccccccc}
$\begin{array}{l}\text { Type of } \\
\text { deposit }\end{array}$ & $\begin{array}{c}\text { Source } \\
\text { of } \\
\text { boulder }\end{array}$ & a-axis & b-axis & c-axis & Shape & $\begin{array}{c}\text { Volume } \\
\left(\mathrm{m}^{3}\right)\end{array}$ & $\begin{array}{c}\text { Weight } \\
(\mathrm{Mg})\end{array}$ \\
\hline Reworked & $\mathrm{B}$ & 3.2 & 3.0 & 1.6 & $\mathrm{E}$ & 8.3 & 22 \\
debris & $\mathrm{B}$ & 2.9 & 1.8 & 1.4 & $\mathrm{E}$ & 7.3 & 20 \\
fan & $\mathrm{B}$ & 3.9 & 2.2 & 1.6 & $\mathrm{E}$ & 7.2 & 19 \\
(rwr) & $\mathrm{B}$ & 3.9 & 1.8 & 1.7 & $\mathrm{E}$ & 6.2 & 17 \\
& $\mathrm{~B}$ & 2.8 & 1.7 & 1.6 & $\mathrm{~T}$ & 3.8 & 10 \\
& $\mathrm{~B}$ & 2.4 & 1.7 & 1.6 & $\mathrm{E}$ & 3.5 & 9.5 \\
& $\mathrm{~B}$ & 3.7 & 1.9 & 0.9 & $\mathrm{~T}$ & 3.4 & 9.1 \\
& $\mathrm{~B}$ & 2.5 & 1.4 & 0.9 & $\mathrm{E}$ & 3.3 & 8.6 \\
& $\mathrm{~B}$ & 1.8 & 1.7 & 1.4 & $\mathrm{H}$ & 2.5 & 6.7 \\
& $\mathrm{~B}$ & 2.4 & 1.2 & 0.8 & $\mathrm{~T}$ & 1.1 & 3.0 \\
Channel & $\mathrm{W}$ & 8 & 7 & 4.4 & $\mathrm{R}$ & 250 & 640 \\
of & $\mathrm{B}$ & 6.7 & 4.8 & 4.3 & $\mathrm{E}$ & 72 & 195 \\
Prospect & $\mathrm{B}$ & 10 & 7 & 3.8 & $\mathrm{SE}$ & 70 & 190 \\
Canyon & $\mathrm{B}$ & 4.8 & 4.5 & 4.3 & $\mathrm{E}$ & 49 & 131 \\
(rwr) & $\mathrm{B}$ & 4.7 & 3.9 & 2.1 & $\mathrm{EC}$ & 30 & 82 \\
& $\mathrm{~B}$ & 5.0 & 3.4 & 3.1 & $\mathrm{E}$ & 28 & 74 \\
& $\mathrm{~B}$ & 6.5 & 4.9 & 2.8 & $\mathrm{SE}$ & 23 & 63 \\
& $\mathrm{~B}$ & 3.6 & 2.7 & 2.1 & $\mathrm{R}$ & 20 & 55 \\
& $\mathrm{~B}$ & 4.0 & 3.4 & 2.9 & $\mathrm{~T}$ & 20 & 53 \\
& $\mathrm{~B}$ & 4.5 & 3.2 & 2.5 & $\mathrm{E}$ & 19 & 51 \\
& & & & & & & \\
\hline
\end{tabular}

Notes: Only the ten largest boulders transported during the indicated debris flow are listed in this table. For descriptions of the source rocks, see Huntoon and others (1986). W -- welded tuff $(2.60 \mathrm{Mg} / \mathrm{m} 3)$, B -- basalt $\left(2.70 \mathrm{Mg} / \mathrm{m}^{3}\right)$, S -- Supai sandstone $\left(2.65 \mathrm{Mg} / \mathrm{m}^{3}\right)$, SU -- Surprise Canyon Formation $\left(2.65 \mathrm{Mg} / \mathrm{m}^{3}\right)$, RW -Redwall Limestone $\left(2.65 \mathrm{Mg} / \mathrm{m}^{3}\right), \mathrm{M}$-- Muav Limestone $\left(2.65 \mathrm{Mg} / \mathrm{m}^{3}\right)$. Boulder axes are based on idealized geometric shapes: E -- ellipsoid, EC -- elliptical cylinder, SE -- semi-ellipsoid, T -- triangular solid, R -rectangular solid. a-axis, the longest dimension of the boulder; b-axis, the intermediate dimension of the boulder; and c-axis, the shortest dimension of the boulder. 